\title{
REMOÇÃO DE FITOPLANCTON E MICROCISTINA DE ÁGUAS DE ABASTECIMENTO, PELA ASSOCIAÇÃO DAS TÉCNICAS DE FLOTAÇÃO POR AR DISSOLVIDO E OXIDAÇÃO QUÍMICA COM CLORO E PERMANGANATO DE POTÁSSIO
}

\section{MAURÍCIO FERNANDES PEREZ}

Tese apresentada à Escola de Engenharia de São Carlos da Universidade de São Paulo, como parte dos requisitos para obtenção do Título de Doutor em Engenharia Civil na área de Hidráulica e Saneamento.

Orientador:

Prof. Dr. Marco Antônio Penalva Reali

São Carlos

2008 
AUTORIZO A REPRODUÇÃO E DIVULGAÇÃO TOTAL OU PARCIAL DESTE TRABALHO, POR QUALQUER MEIO CONVENCIONAL OU ELETRÔNICO, PARA FINS DE ESTUDO E PESQUISA, DESDE QUE CITADA A FONTE.

Ficha catalográfica preparada pela Seção de Tratamento da Informação do Serviço de Biblioteca - EESC/USP

P438r

Perez, Maurício Fernandes

Remoção de fitoplancton e microcistina de águas de abastecimento, pela associação das técnicas de flotação por ar dissolvido e oxidação química com cloro e permanganato de potássio / Maurício Fernandes Perez ; orientador Marco Antônio Penalva Reali. -- São Carlos, 2008 .

Tese (Doutorado) - Programa de Pós-Graduação e Área de Concentração em Hidráulica e Saneamento. -- Escola de Engenharia de São Carlos da Universidade de São Paulo.

1. Microcistina. 2. Fitoplâncton. 3. Flotação. 4. Oxidação com Permanganato de potássio. 5. Oxidação com cloro. 6. Trialometanos - remoção. 7. Trialometanos formação. I. Título. 
Candidato: Engenheiro MAURICIO FERNANDES PEREZ

Tese defendida e julgada em 16/05/2008 perante a Comissão Julgadora:

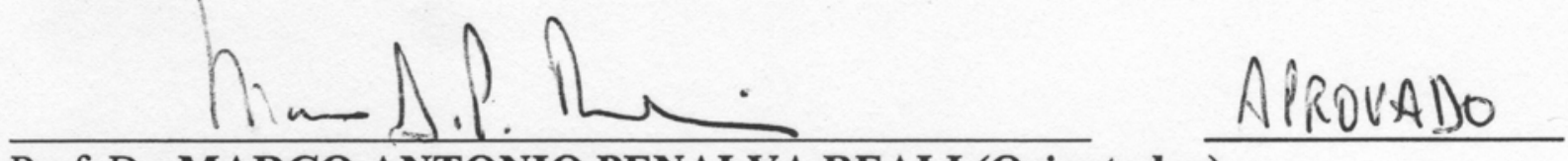

Prof. Dr. MARCO ANTONIO PENALVA REALI (Orientador)

(Escola de Engenharia de São Carlos/USP)

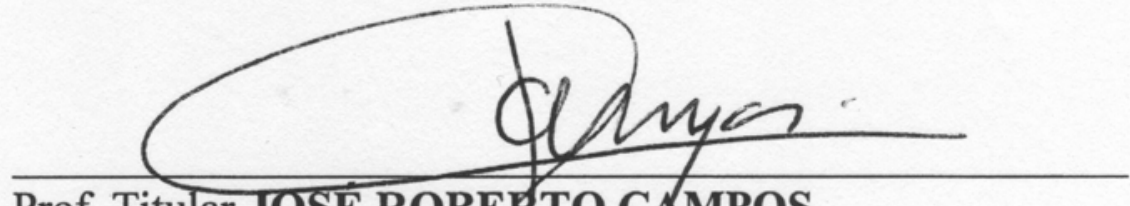

APROVADO

Prof. Titular JOSE ROBERTO CAMPOS

(Escola de Engenharia de São Carlos/USP)

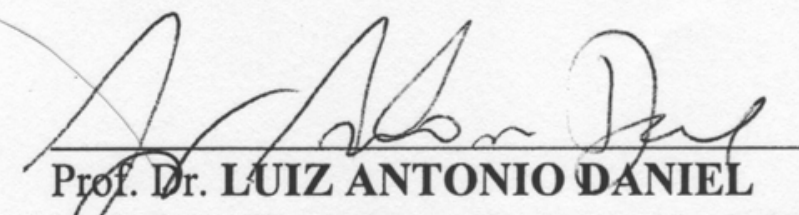

APROUADO

(Escola de Engenharia de São Carlos/USP)

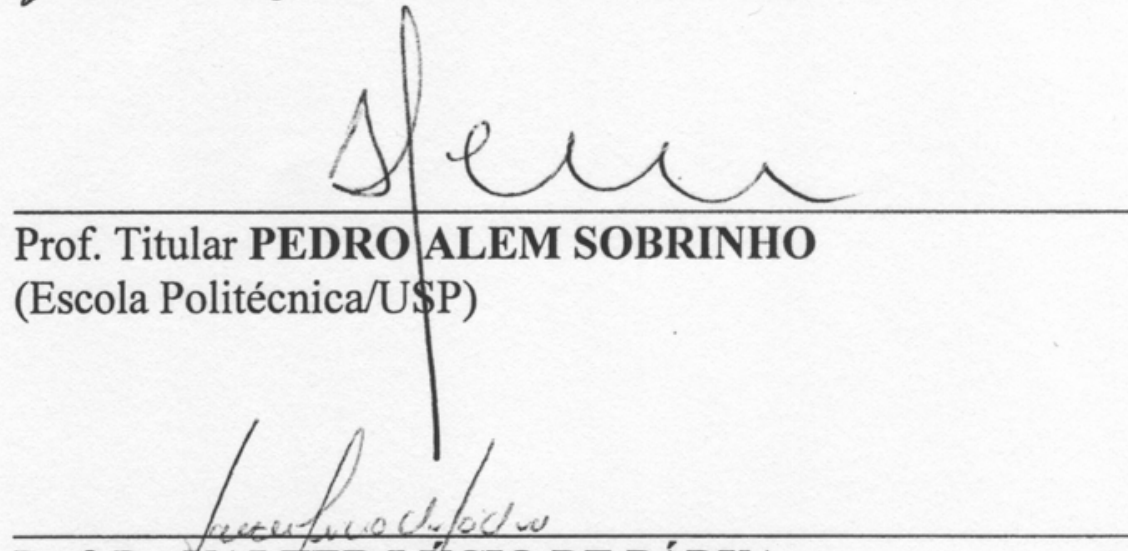

APROVAO

Prof. Dr. WALTER LÚCIO DE PÁDUA

(Universidade Federal de Minas Gerais/UFMG)

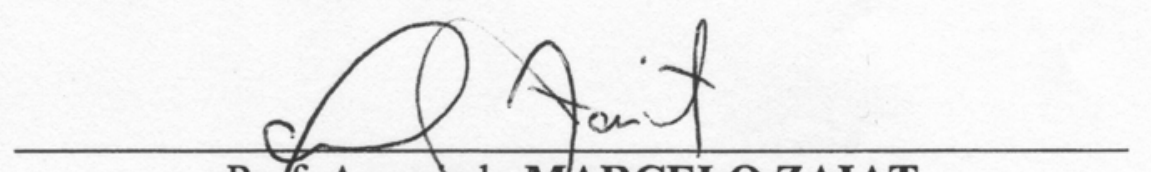

Prof. Associado MARCELO ZAIAT

Coordehador do Prdgrama de Pós-Graduação em

Ehgenharia (Hidráulica e Saneamento)

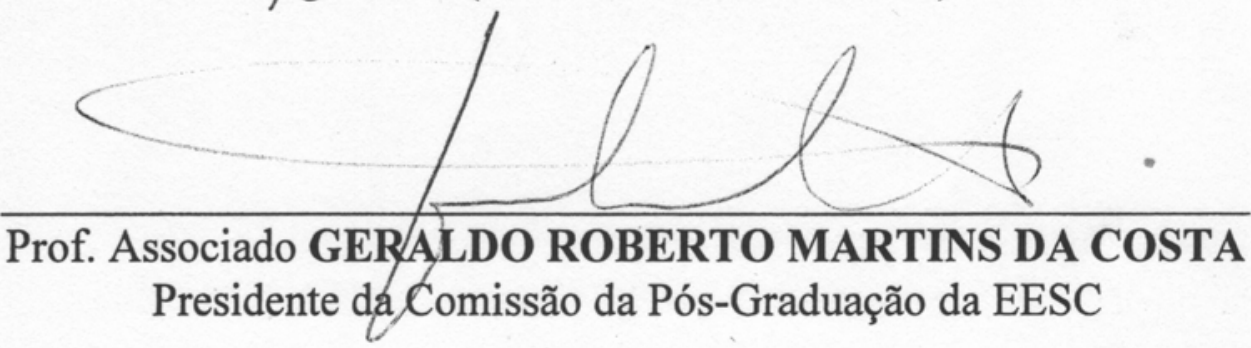


Aos meus pais, Lilia e Francisco, pelos ensinamentos, dedicação, apoio $e$ presença nos momentos importantes de minha vida. 
À minha esposa Evelise e aos meus filhos Gabriel e Breno, pelo carinho, compreensão e, principalmente, por serem a razão maior de meu esforço para cumprir mais esta etapa de minha carreira profissional. 


\section{AGRADECIMENTOS}

Ao professor Dr. Marco Antônio Penalva Reali pela sua compreensão e, principalmente, pela sua competente e precisa orientação.

Aos professores Maria do Carmo Calijuri, Luiz Antônio Daniel, José Roberto Campos e Bernardo Arantes do Nascimento Teixeira, pelas avaliações preliminares e valiosas sugestões para o enriquecimento deste trabalho.

Ao professor e parceiro de profissão Benedito A. dos Santos Rodrigues, pelas suas contribuições e pertinentes sugestões.

À FAPESP - Fundação de Amparo à Pesquisa do Estado de São Paulo e ao CNPq - Conselho Nacional de Desenvolvimento Científico e Tecnológico e à CAPES Coordenação de Aperfeiçoamento de Pessoal de Nível Superior, pelos auxílios financeiros concedidos.

À AES Tietê S/A, por autorizar a coleta de água no reservatório de Barra Bonita, em especial, ao responsável técnico pela piscicultura, José Luiz Gonçalves, pela ajuda nos procedimentos de coleta.

Aos colegas Andrey A. Rosa, Eduardo Migliati, Fernando Brizola, André Luis Silva e Luciana Hespanholo Ferreira, que, como membros do grupo de pesquisa, colaboraram de maneira relevante para a realização deste trabalho.

À Leila J. Patrizzi, pelas sugestões e apoio em todos os momentos.

À Glauce G. Pereira, pela valiosa colaboração nas determinações analíticas, em especial nas determinações de microcistina. 
À Patrícia B. de Falco, pela grande colaboração na identificação e contagem de microrganismos.

Aos técnicos Paulo, Júlio e Juliana, pela grande colaboração nas determinações de NTK, amônia, COT e manganês total.

À Evelise M. Guariglia, pela revisão de texto e sugestões para a melhoria da qualidade de redação.

A todos os funcionários do departamento de Hidráulica e Saneamento, pelo pronto e gentil atendimento em todos os momentos.

A todos os meus familiares, amigos e colegas de trabalho, pela compreensão, amizade e apoio. 


\section{SUMÁRIO}

LISTA DE TABELAS__ $X$

LISTA DE FIGURAS __ Xiii

LISTA DE ABREVIATURAS, SIGLAS E SÍMBOLOS___ XVii

RESUMO $\quad$ iix

ABSTRACT XX

1 - INTRODUÇÃO E JUSTIFICATIVA

2 - OBJETIVOS 26

3 - REVISÃO DE LITERATURA _ 27

3.1. Cianobactérias __ 27

3.2 - Cianotoxinas __ 30

3.2.1 - Neurotoxinas ___ 31

3.2.2 - Hepatotoxinas __ 33

3.2.3 - Dermatotoxinas __ 37

3.2.4 - Degradação de Cianotoxinas ___ 39

3.3 - Eutrofização - origem, efeitos e controle

3.3. Métodos de Deteç̧ão de Cianotoxinas ___ 44

3.3.1. Bioensaios___ 45

3.3.2. Métodos Cromatográficos _ـ 45

3.3.3. Ensaios de Inibição de Fosfatase ___ 46

3.3.4. Ensaios Imunológicos___ 47

3.4 - A remoção de Cianobactérias e Cianotoxinas nos Sistemas de Tratamento de Água 48

3.4.1 - O Emprego de Técnicas Convencionais de Tratamento (Coagulação / Floculação / Sedimentação / Filtração) 
3.6 - Resultados dos Estudos Anteriores Realizados no Laboratório de Tratamento Avançado

e Reuso de Águas - EESC/USP

3.6.1 - Generalidades 66

3.6.2 - Dissertação de Mestrado intitulada - "Remoção de Biomassa Algal e Avaliação do Método Elisa para Determinação da Concentração de Microcistina em Ensaios de Coagulação, Sedimentação e Adsorção Realizados com Água Proveniente de Reservatório Eutrofizado“

3.6.3 - Dissertação de Mestrado intitulada - "Remoção de Fitoplancton e Microcistina de Águas para Abastecimento em Sistema que Associa Unidades de Adsorção por Carvão Ativado em Pó, Flotação por Ar

Dissolvido e Filtração em Escala de Laboratório" 70

3.6.4 - Dissertação de Mestrado intitulada - “ Tratamento de Água para Abastecimento Contendo Cianobactérias e Microcistina em Sistema Constituído por Etapas de Pré-cloração, Coagulação, Floculação, Flotação e Adsorção em Carvão Ativado"

3.6.5 - Trabalho de Iniciação Científica Intitulado - "Monitoramento da Evolução da Toxicidade de Uma Cultura de Microcystis aeruginosa e Avaliação da remoção de Microcistina por Oxidação com Hipoclorito de Sódio, Coagulação e Flotação por Ar Dissolvido" 77

4-MATERIAIS E MÉTODOS 80

4.1 - Considerações Iniciais 80

4.2 - A Água de Estudo 83

4.2.1 - Preparo e Conservação 83

4.2.2 - Coleta e Caracterização da Água de Barra Bonita 83

4.2.3 - A Cultura de Cianobactérias 88

4.3 - Equipamentos 91

4.4 - Descrição dos Ensaios 93

4.4.1 - Generalidades 93

4.4.2 - Ensaios para Definir o Método de Preparo de Amostras para a Medição de Microcistina Total _ 96

4.4.3 - Pós Oxidação Química com Cloro 98

4.4.4 - Inter-Oxidação Química com Permanganato de Potássio 105

4.4.5 - Pré-Oxidação com Permanganato de Potássio Associada à Pós-Oxidação com Cloro 111

4.4.6 - Pré-Oxidação com Permanganato de Potássio e Cloro Associada à Pós-Oxidação com Cloro _ 116 
4.5.1 - Generalidades

4.5.2 - Contagem e Identificação do Fitoplancton

4.5.3 - Clorofila-a

4.5.4 - Microcistina Extracelular 125

\section{1 - Congelamento e Descongelamento de Amostras para a Avaliação da Concentração de} Microcistina Total

\section{2 - Pós Oxidação com Cloro}

5.2.1 - ETAPA I - Investigação das Condições de Coagulação da Água de Estudo e Determinação da Curva de Residual de Cloro na Água Filtrada

5.2.2 - ETAPA II - Investigação a Influência da Pós-oxidação com Cloro na Remoção da Microcistina 133

5.2.3 - ETAPA III - Investigação da Influência da Variação do pH na Pós-oxidação com Cloro visando a Remoção da Microcistina

5.2.4 - Considerações Referentes ao Comportamento Global da Remoção da Microcistina nos Diferentes Estágios do Fluxograma de Tratamento

5.3.1 - ETAPA I - Investigação das Condições de Coagulação da Água de Estudo e Avaliação da Máxima Dosagem Viável de Permanganato de Potássio na Água submetida à flotação

5.3.2 - ETAPA II - Investigação da Remoção de Microcistina Considerando a Máxima Dosagem Viável de Permanganatode Potássio na Inter-oxidação e a Variação de $\mathrm{pH}$

5.3.3 - ETAPA III - Investigação da Remoção de Microcistina Considerando a Máxima Dosagem Viável de Permanganato de Potássio associado ao Cloro na Inter-oxidação e a Variação de pH 154

5.3.4 - Considerações com Relação ao Comportamento Global da Remoção da Microcistina nos Diferentes Estágios do Fluxograma de Tratamento

\section{4 - Pré-Oxidação com Permanganato de Potássio Associada à Pós-Oxidação com Cloro _ 161}

5.4.1 - ETAPA I - Investigação das Condições de Coagulação da Água de Estudo e Avaliação da Máxima Dosagem Viável de Permanganato de Potássio na Água de Estudo 161

5.4.2 - ETAPA II - Investigação da Remoção de Microcistina Considerando a Máxima Dosagem Viável de Permanganato de Potássio na Pré-oxidação Associada à Pós-oxidação com Cloro e a Variação de pH_164

5.4.3 - Considerações com Relação ao Comportamento Global da Remoção da Microcistina nos Diferentes Estágios do Fluxograma de Tratamento 
5.5 - Pré-Oxidação com Permanganato de Potássio e Cloro Associada à Pós-Oxidação com Cloro

5.5.1 - ETAPA I - Investigação das Condições de Coagulação da Água de Estudo e Avaliação da Máxima Dosagem Viável de Permanganato de Potássio na Água Bruta

5.5.2 - ETAPA II - Ensaios Destinados à Investigação da Remoção de Microcistina Considerando a Máxima Dosagem Viável de Permanganato na Pré-oxidação Associada à Pré-oxidação e Pós-oxidação com Cloro, com Variação de $\mathrm{pH}$

5.5.3 - Considerações Referentes ao Comportamento Global da Remoção da Microcistina nos Diferentes Estágios do Fluxograma de Tratamento

5.6 - Ensaios Complementares 182

5.6.1 - Generalidades 182

5.6.2 - Matéria Orgânica e Trialometanos 185

5.6.3 - Fitoplancton

5.7 - Análise Global dos Resultados 205

5.8 - Estudo Econômico Simplificado 219

6-CONCLUSÕES 226

7 - RECOMENDAÇÕES 229

7 - RECOMENDAÇÕES 229

8 - REFERÊNCIAS BIBLIOGRÁFICAS 231 ANEXO - MEMORIAIS DE CÁLCULO DO ESTUDO ECONÔMICO SIMPLIFICADO 


\section{LISTA DE TABELAS}

Tabela 3.1 - Cianotoxinas, alvo primário em mamíferos e principais gêneros responsáveis pela produção das mesmas.

Tabela 3.2 - Toxicidade de diversas toxinas conhecidas 39

Tabela 4.1 - Índices Médios Anuais de Qualidade das Águas do Reservatório de Barra Bonita -Ano de 2006

Tabela 4.2 - Condições dos Ensaios Complementares

Tabela 4.3 - Protocolos de Determinação Analítica dos Parâmetros de Controle Adotados, de acordo com o Standard Methods for the Examination of Water and Wastewater.

Tabela 5.1 - Contagem de Fitoplancton, Eficiência de Lise Celular e Concentração de Microcistina

Tabela 5.2 - Características Qualitativas de Água de Estudo 1

Tabela 5.3 - Características Qualitativas das Águas Flotada e Filtrada Produzidas 131

Tabela 5.4 - Concentrações de Cloro Livre Residual na Água Filtrada, com pH = 7,43 _ 131

Tabela 5.5 - Resultados dos Ensaios de Oxidação da Água Filtrada, com Cloro.

Concentração de microcistina extracelular na água de estudo de $15 \mu \mathrm{g} . \mathrm{L}^{-1}$ e $\mathrm{pH}$ de 6,93.

Tabela 5.6 - Influência da variação do pH na pós-oxidação da água filtrada com cloro. Concentração de microcistina na água de estudo de 15,7 $\mu \mathrm{g} \cdot \mathrm{L}^{-1}$.

Tabela 5.7 - Concentrações de Microcistina Intracular e Extracelular nos Ensaios de Pósoxidação com Cloro.

Tabela 5.8 - Eficiências de Remoção de Microcistina Total e Extracelular nas Diversas Etapas do Fluxograma de Tratamento da Condição de Pós-oxidação com Cloro

Tabela 5.9 - Características Qualitativas de Água de Estudo 2

Tabela 5.10 - Ensaios de Inter-oxidação com Permanganato de Potássio. Características Qualitativas das Águas Flotada e Filtrada Produzidas.

Tabela 5.11 - Cor, Turbidez e Manganês Total após a Aplicação de Permanganato de Potássio na Água submetida à flotação, com Tempo de Contato de 60 minutos antes da filtração.

Tabela 5.12 - Cor, Turbidez e Manganês Total com a Aplicação de Permanganato de Potássio na água submetida à flotação, com Tempo de Contato de 15 minutos antes da filtração.

Tabela 5.13 - Cor, Turbidez e Manganês Total na Aplicação de Permanganato de Potássio e Cloro na água submetida à flotação, com Tempo de Contato de 60 minutos antes da filtração. Dosagem de cloro $=3,0 \mathrm{mg} \cdot \mathrm{L}^{-1}$.

Tabela 5.14 - Influência da variação do pH na remoção de microcistina nos ensaios de oxidação com permanganato de potássio da água submetida à flotação. Concentração de microcistina na água de estudo de $15,7 \mu \mathrm{g} . \mathrm{L}^{-1}$. 
Tabela 5.15 - Influência da variação do pH na remoção de microcistina nos ensaios de oxidação, com permanganato de potássio e cloro, da água submetida à flotação

Tabela 5.16 - Concentrações de Microcistina Intracelular e Extracelular nos Ensaios de Inter-oxidação com Permanganato de Potássio e com a Associação de Permanganato de Potássio e Cloro

Tabela 5.17 - Eficiências de Remoção de Microcistina Total e Extracelular nas Diversas Etapas do Fluxograma de tratamento

Tabela 5.18 - Características Qualitativas de Água de Estudo 3

Tabela 5.19 - Características Qualitativas das Águas Préviamente Flotada e Filtrada Produzidas

Tabela 5.20 - Influência da variação do pH na remoção de microcistina nos ensaios de préoxidação com permanganato de potássio, flotação e pós-oxidação com cloro. Dosagem de cloro de 3,0 mg. $\mathrm{L}^{-1}$.

Tabela 5.21 - Influência da variação do pH na remoção de microcistina nos ensaios de préoxidação com permanganato de potássio, flotação e pós-oxidação com cloro. Dosagem de cloro de 7,0 mg. $\mathrm{L}^{-1}$.

Tabela 5.22 - Concentrações de Microcistina Intracelular e Extracelular nos Ensaios de Préoxidação com Permanganato de Potássio e Pós-oxidação com Cloro (dosagem $\left.\operatorname{de} C l_{2}=3,0 \mathrm{mg} / \mathrm{L}^{-1}\right)$

Tabela 5.23 - Eficiências de remoção de microcistina total e extracelular nas diversas etapas do fluxograma de tratamento

Tabela 5.25 - Características Qualitativas das Águas Flotada e Filtrada Produzidas nos ensaios de pré-oxidação com a associação de permanganato de potássio e cloro.

Tabela 5.26 - Influência da variação do pH na remoção de microcistina, nos ensaios de préoxidação com permanganato de potássio e cloro, flotação e pós-oxidação com cloro. Concentração de microcistina na água de estudo de $14,0 \mu \mathrm{g} \cdot \mathrm{L}^{-1}$. 176

Tabela 5.27 - Concentrações de microcistina intracelular e extracelular nos ensaios de préoxidação com permanganto de potássio e cloro e pós-oxidação com cloro. _ 179

Tabela 5.28 - Eficiências de Remoção de Microcistina total e extracelular ao longo do fluxograma de tratamento

Tabela 5.29 - Caracterização Qualitativa da Água de Estudo 5

Tabela 5.30 - Matéria orgânica e trihalometanos nos ensaios de pós-oxidação com Cloro. Dosagem de cloro de 7,0 mg. $\mathrm{L}^{-1}$.

Tabela 5.31 - Matéria orgânica e trihalometanos nos ensaios de inter-oxidação com permanganato de potássio (dosagem de $0,2 \mathrm{mg} . \mathrm{L}^{-1}$ ) e de inter-oxidação com a associação de permanganato de potássio e cloro (dosagem de permanganato de 0,3 mg. $\mathrm{L}^{-1}$ e cloro de 3,0 mg. $\left.\mathrm{L}^{-1}\right)$.

Tabela 5.32 - Matéria orgânica e trihalometanos nos ensaios de pré-oxidação com permanganato de potássio (dosagem de permanganato de 3,0 mg. $L^{-1}$ ) e pósoxidação com cloro (dosagens de cloro de 3,0 e 7,0 mg. $\mathrm{L}^{-1}$ ). 
Tabela 5.33 - Matéria orgânica e trihalometanos nos ensaios de pré-oxidação com a associação do permanganato de potássio (dosagem de permanganato de 4,0 mg. $L^{-1}$ ) e cloro (dosagem de 2,0 mg. $L^{-1}$ ) e pós-oxidação com cloro (dosagem de 3,0 $\left.\mathrm{mg} \cdot \mathrm{L}^{-1}\right)$.

Tabela 5.34 - Remoção de Microcistina Extracelular e Trialometanos. Resumo Geral das Condições Experimentais Estudadas pelo Grupo de Pesquisa formado por SILVA (2005), BUENO (2005), MIGLIATI (2006) e por este autor.

Tabela 5.34 - Remoção de Microcistina Extracelular e Trihalometanos. Resumo Geral das Condições Experimentais Estudadas pelo grupo de Pesquisa formado por SILVA (2005), BUENO (2005), MIGLIATI (2006) e por este autor. (Continuação) 218

Tabela 5.35 - Resumo dos Custos Unitários e Eficiências de Remoção de Microcistina 222 


\section{LISTA DE FIGURAS}

Figura 3.1 - Efeitos da antoxina-a e da antoxina-a(s) na contração muscular. 33

Figura 3.2 - Efeitos da saxitoxina na propagação do impulso nervoso. 33

Figura 3.3 - Estrutura química de hepatotoxinas: (1) Estrutura geral das microcistina, (2) Estrutura geral das nodularinas e (3) Estrutura da cilindrospermopsina. 35

Figura 3.4 - Efeitos das hepatotoxinas no fígado 37

Figura 3.5 - Esquema Ilustrativo do Método ELISA 48

Figura 4.1 - Localização do reservatório de Barra Bonita, das UGRHI's 5 e 10 e dos pontos de monitoração da CETESB. 88

Figura -4.2- Vista dos frascos empregados para o cultivo 89

Figura 4.3- Ilustração geral da sala de cultivo. 90

Figura 4.4 - Detalhes do termômetro e do climatizador 90

Figura 4.5 - Detalhes das lâmpadas 90

Figura 4.6 - Vista geral da câmara de radiação ultravioleta 91

Figura 4.7 - Detalhes das lâmpadas de radiação ultravioleta. 91

Figura 4.8 - Equipamento de jarteste. 92

Figura-4.9- Equipamento de flotateste. 93

Figura 4.11 - Fluxograma geral dos ensaios 95

Figura 4.12 - Esquema dos Ensaios Destinados ao Estudo da Pós-oxidação Química com Cloro 100

Figura 4.13 - Esquema dos Ensaios Destinados ao Estudo da Inter-oxidação Química com Permanganato de Potássio

Figura 4.14 - Esquema dos Ensaios Destinados ao Estudo da Associação da Pré-oxidação com Permanganato de Potássio e Pós-oxidação com Cloro

Figura 4.15 - Esquema dos Ensaios Destinados ao Estudo da Associação da Pré-oxidação com Permanganato de Potássio e Cloro e Pós-oxidação com Cloro

Figura 5.1 - Relação entre o número de ciclos de congelamento e descongelamento da amostra e a contagem de células íntegras remanescentes

Figura 5.2 - Relação entre o número de ciclos de congelamento e descongelamento da amostra e a concentração de microcistina dissolvida no meio líquido.

Figura 5.3 - Residual de Cloro na Água Filtrada para tempo de contato de 30 minutos. _ 132

Figura 5.4 - Concentrações Remanescentes de Microcistina após a Oxidação da água filtrada com cloro

Figura 5.5 - Residuais de Cloro na Água Filtrada após a Oxidação

Figura 5.6 - Concentrações Remanescentes de Microcistina após a Oxidação da água filtrada com cloro. Dosagem de cloro de 7,0 mg..$^{-1}$; tempo de contato de $30 \mathrm{~min}$ e variação de $\mathrm{pH}$ 
Figura 5.7 - Residuais de Cloro na Água Filtrada. Dosagem de cloro de 7,0 mg. $L^{-1}$, tempo de contato de 30 minutos e variação de $\mathrm{pH}$

Figura 5.8 - Concentrações Remanescentes de Microcistina ao Longo do Fluxograma de Tratamento

Figura 5.9 - Eficiências de remoção de Microcistina ao Longo do Fluxograma de Tratamento

Figura 5.10 - Cor da Água Filtrada na Inter-oxidação com o Permanganato de Potássio. Tempos de contato para oxidação de 15 e 60 minutos.

Figura 5.11 - Turbidez da Água Filtrada na Inter-oxidação com o Permanganato de Potássio. Tempos de contato para oxidação de 15 e 60 minutos.

Figura 5.12 - Concentração Remanescente de Manganês Total na Água Filtrada na Interoxidação com o Permanganato de Potássio. Tempos de contato para oxidação de 15 e 60 minutos.

Figura 5.13 - Cor da Água Filtrada nos Ensaios de Inter-oxidação com o Permanganato de Potássio e Cloro. Dosagem de cloro de 3,0 mg. $\mathrm{L}^{-1}$, tempo de contato para a oxidação de 15 minutos.

Figura 5.14 - Turbidez da Água Filtrada nos Ensaios de Inter-oxidação com o

Permanganato de Potássio e Cloro. Dosagem de cloro de 3,0 mg. $\mathrm{L}^{-1}$, tempo de contato para a oxidação de 15 minutos.

Figura 5.15 - Concentração Remanescente de Manganês Total na Água Filtrada na Interoxidação com o Permanganato de Potássio e Cloro, tempo de contato de 15 minutos.

Figura 5.16 - Concentrações Remanescentes de Microcistina após a Oxidação, com Permanganato de Potássio, da água submetida à flotação. Dosagem de Permanganato de 0,2 mg. $\mathrm{L}^{-1}$, tempo de contato para a oxidação de 15 minutos.

Figura 5.17 - Residuais de Permanganato na Água submetida à flotação. Dosagem de permanganato $=0,2 \mathrm{mg} \cdot \mathrm{L}^{-1}$, tempo de contato de 15 minutos.

Figura 5.18 - Concentrações remanescentes de microcistina após a oxidação, com permanganato de potássio e cloro, da água submetida à flotação. Dosagem de permanganato de 0,3 $\mathrm{mg} / \mathrm{l}$, dosagem de cloro de 3,0 $\mathrm{mg} / \mathrm{l}$, tempo de contato para a oxidação de 15 minutos.

Figura 5.19 - Residuais de permanganato e cloro na água oxidada. Dosagem de permanganato de $0,3 \mathrm{mg} \cdot \mathrm{L}^{-1}$, dosagem de cloro de 3,0 mg. $\mathrm{L}^{-1}$ e tempo de contato para oxidação de 15 minutos.

Figura 5.20 - Concentrações Remanescentes de Microcistina ao Longo do Fluxograma de Tratamento. Nos ensaios de inter-oxidação com $\mathrm{KMnO}_{4}$, dosagem de permanganato de 0,2 mg. $\mathrm{L}^{-1}$. Nos ensaios de inter-oxidação com a associação do $\mathrm{KMnO}_{4}$ e $\mathrm{Cl}_{2}$ as dosagens de permanganato e cloro foram respectivamente iguais a $0,3 \mathrm{mg} \cdot \mathrm{L}^{-1}$ e 3,0 mg. $\mathrm{L}^{-1}$.

Figura 5.21 - Eficiências de remoção de Microcistina ao Longo do Fluxograma de Tratamento. Nos ensaios de inter-oxidação com $\mathrm{KMnO}_{4}$, dosagem de permanganato de 0,2 mg. $\mathrm{L}^{-1}$. Nos ensaios de inter-oxidação com a associação 
do $\mathrm{KMnO}_{4}$ e $\mathrm{Cl}_{2}$ as dosagens de permanganato e cloro foram respectivamente iguais a $0,3 \mathrm{mg} \cdot \mathrm{L}^{-1}$ e 3,0 mg. $\mathrm{L}^{-1}$.

Figura 5.22 - Concentrações remanescentes de Microcistina após a pré-oxidação da água de estudo com permanganato de potássio e pós-oxidação com cloro. Dosagem de permanganto de 3,0 mg. $\mathrm{L}^{-1}$, dosagem de cloro de 3,0 mg. $\mathrm{L}^{-1}$ e tempo de contato para a pós-oxidação com cloro de 30 minutos.

Figura 5.23 - Residuais de permanganato e cloro na água pré-oxidada e submetida à flotação. Dosagem de permanganato de 3,0 mg. $\mathrm{L}^{-1}$, dosagem de cloro de 3,0 mg. $L^{-1}$ e tempo de contato para a pós-oxidação de 30 minutos.

Figura 5.24 - Concentrações remanescentes de Microcistina após a pré-oxidação da água de estudo com permanganato de potássio e pós-oxidação com cloro. Dosagem de permanganato de 3,0 mg. $\mathrm{L}^{-1}$, dosagem de cloro de 7,0 mg. $\mathrm{L}^{-1}$ e tempo de contato para a pós-oxidação com cloro de 30 minutos.

Figura 5.25 - Residuais de permanganato e cloro na água filtrada. Dosagem de permanganato de 3,0 mg. $\mathrm{L}^{-1}$, dosagem de cloro de 7,0 mg. $\mathrm{L}^{-1}$ e tempo de contato para a pós-oxidação de 30 minutos.

Figura 5.26 - Concentrações remanescentes de microcistina ao longo do fluxograma de tratamento. Nos ensaios de pré-oxidação dosagem de permanganato de 3,0 $m g . L^{-1}$. Nos ensaios de pós-oxidação dosagem de cloro de 3,0 mg. $\mathrm{L}^{-1}$.

Figura 5.27 - Eficiências de remoção de microcistina ao longo do fluxograma de tratamento. Nos ensaios de pré-oxidação dosagem de permanganato de 3,0 mg. $\mathrm{L}^{-1}$. Nos ensaios de pós-oxidação dosagem de cloro de 3,0 mg. $\mathrm{L}^{-1}$.

Figura 5.28 - Concentrações remanescentes de Microcistina após a pré-oxidação da água de estudo com permanganato de potássio e cloro e pós-oxidação com cloro.

Dosagem de permanganato de 4,0 mg. $\mathrm{L}^{-1}$, dosagem de cloro na pré-oxidação de 2,0 mg. $\mathrm{L}^{-1}$, dosagem de cloro na pós-oxidação de 3,0 mg. $\mathrm{L}^{-1}$ e tempo de contato na pós-oxidação de 30 minutos. 176

Figura 5.29 - Residuais de permanganato e cloro na água filtrada. Dosagem de permanganato de 4,0 mg. $\mathrm{L}^{-1}$, dosagem de cloro na pré-oxidação de 2,0 mg. $\mathrm{L}^{-1}$, dosagem de cloro na pós-oxidação de 3,0 mg. $\mathrm{L}^{-1}$ e tempo de contato na pósoxidação de 30 minutos.

Figura 5.30 - Concentrações Remanescentes de Microcistina ao Longo do Fluxograma de Tratamento. Nos ensaios de pré-oxidação dosagem de permanganato de 4,0 $\mathrm{mg} . \mathrm{L}^{-1}$ e cloro de $2,0 \mathrm{mg} . \mathrm{L}^{-1}$. Nos ensaios de pós-oxidação dosagem de cloro de 3,0 mg. $\mathrm{L}^{-1}$.

Figura 5.31 - Eficiências de remoção de Microcistina ao Longo do Fluxograma de

Tratamento. Nos ensaios de pré-oxidação dosagem de permanganato de 4,0 $\mathrm{mg} . \mathrm{L}^{-1}$ e cloro de $2,0 \mathrm{mg} . \mathrm{L}^{-1}$. Nos ensaios de pós-oxidação dosagem de cloro de 3,0 mg. $\mathrm{L}^{-1}$.

Figura 5.32 - Quantidade e Composição do Fitoplancton da Água de Estudo 5 185

Figura 5.33 - Matéria orgânica e trihalometanos nos ensaios de pós-oxidação com cloro. Dosagem de cloro de 7,0 mg/l.

Figura 5.34 - Matéria orgânica e trialometanos nos ensaios de inter-oxidação com permanganato de potássio $\left(\mathrm{MnO}_{4}{ }^{-}\right.$de $\left.0,2 \mathrm{mg} / \mathrm{l}\right)$ e com a associação de 
permanganato de potássio (dosagem de $\mathrm{MnO}_{4}{ }^{-}$de $0,3 \mathrm{mg} / \mathrm{l}$ ) e Cloro (dosagem de $\mathrm{Cl}_{2}$ de 3,0 $\left.\mathrm{mg} / \mathrm{l}\right)$

Figura 5.35 - Matéria orgânica e trialometanos nos ensaios de pré-oxidação com permanganato de potássio (dosagem de $\mathrm{MnO}_{4}^{-}$de 3,0 mg. $\mathrm{L}^{-1}$ ) e pós-oxidação com cloro (dosagens de $\mathrm{Cl}_{2}$ de 3,0 e 7,0 mg. $\mathrm{L}^{-1}$ )

Figura 5.36 - Matéria orgânica e trihalometanos nos ensaios de pré-oxidação com a associação do permanganato de potássio e cloro (dosagem de $\mathrm{MnO}_{4}^{-}$de 3,0 $\mathrm{mg} . \mathrm{L}^{-1}$ e dosagem de $\mathrm{Cl}_{2}$ de 2,0 mg. $\mathrm{L}^{-1}$ ) e pós-oxidação com cloro (dosagem de $\mathrm{Cl}_{2}$ de 3,0 mg. $\mathrm{L}^{-1}$ )

Figura 5.37 - Contagem de células nos ensaios complementares. Pré-oxidação com permanganato de potássio (dosagem de $\mathrm{MnO}_{4}{ }^{-}$de 3,0 $\mathrm{mg} \cdot \mathrm{L}^{-1}$ ) e pré-oxidação com a associação do permanganato de potássio e cloro (dosagem de $\mathrm{MnO}_{4}{ }^{-}$de 3,0 mg. $\mathrm{L}^{-1}$ e dosagem de $\mathrm{Cl}_{2}$ de 2,0 $\left.\mathrm{mg} \cdot \mathrm{L}^{-1}\right)$.

Figura 5.38 - Contagem e Identificação do Fitoplancton nos Ensaios Complementares _ 202

Figura 5.39 - Concentração de clorofila-a nos ensaios complementares. 204 


\section{LISTA DE ABREVIATURAS, SIGLAS E SÍMBOLOS}

A filt

A flot

A flot/filt

A flot (Pré-Ox)

A flot.Ox

A Inter-Ox

A Pós-Ox (Pré-Ox) ABNT

ABS $_{254}$

AE

CAP

Coag

Cong

COT

D oxid

D coag

Descong

DQO

ELISA

FAD

Filt

Floc

Gf

Gm

Gmr

IAP

IET
Água filtrada

Água submetida à flotação

Água submetida à flotação e filtrada

Água pré-oxidada e flotada

Água submetida à flotação e oxidada

Água inter-oxidada (oxidação após a flotação)

Água pré-oxidada, flotada e pós oxidada

Associação Brasileira de Normas Técnicas

Absorbância ao comprimento de onda igual a $254 \mathrm{~nm}$

Água de estudo (água bruta utilizada nos ensaios)

Carvão ativado em pó

Coagulação

Congelamento

Carbono Orgânico Total

Dosagem de oxidante

Dosagem de coagulante

Descongelamento

Demanda química de oxigênio

Enzyme Linked ImmunoSorbent Assay

Flotação por ar dissolvido

Filtração

Floculação

Gradiente de velocidade para a floculação

Gradiente de velocidade para mistura da amostra nos ensaios de oxidação

Gradiente de velocidade para a mistura rápida na etapa de coagulação

Índice de qualidade das águas brutas para fins de abastecimento público

Índice de estado trófico 


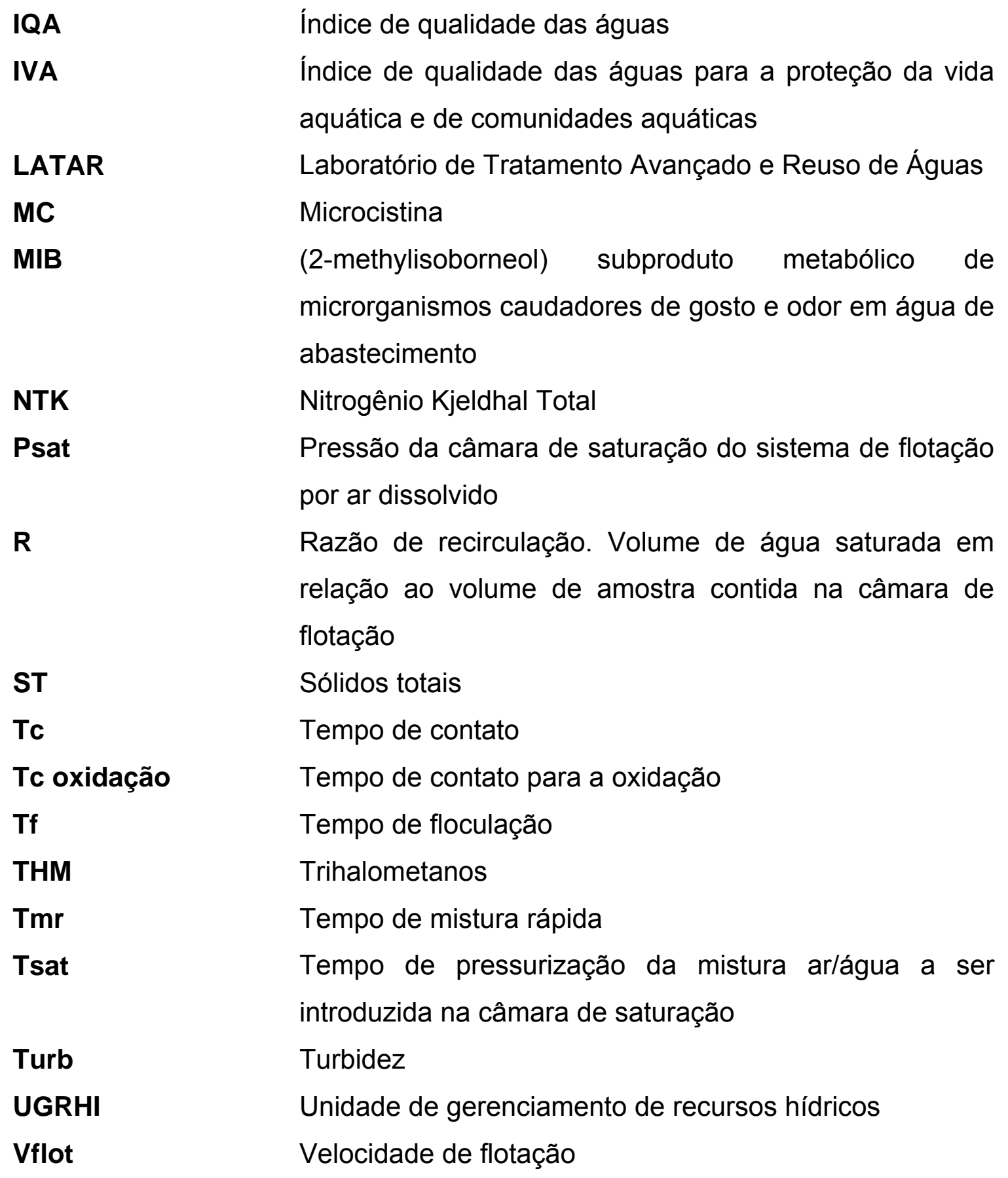




\section{RESUMO}

PEREZ, M. F. (2008). Remoção de Fitoplancton e Microcistina em Águas de Abastecimento, pela Associação das Técnicas de Flotação por Ar Dissolvido e Oxidação Química com Cloro e Permanganato de Potássio. São Carlos, 2008. 254 p. Tese (Doutorado) - Escola de Engenharia de São Carlos da Universidade de São Paulo.

O presente trabalho de pesquisa teve como objetivo principal avaliar a remoção de fitoplancton e microcistina em cinco fluxogramas de tratamento de água para abastecimento, que tiveram como seqüência básica as etapas de coagulação, floculação, flotação por ar dissolvido e filtração, complementados com oxidação química em diferentes pontos da seqüência básica de tratamento estabelecida. Os ensaios foram realizados em escala de laboratório, utilizando água de estudo preparada mediante a mistura de água coletada no reservatório de Barra Bonita, no Estado de São Paulo, e cultura com elevada concentração de microcistina preparada em laboratório. A concentração de microcistina na água de estudo foi mantida no intervalo de 14 a $17 \mu \mathrm{g} \cdot \mathrm{L}^{-1}$. O cloreto férrico foi utilizado como agente coagulante, o permanganato de potássio e o cloro, na forma de hipoclorito de sódio, foram utilizados como agentes oxidantes. Foi observada eficiência de remoção de fitoplancton de cerca de 99,9 \% devido às etapas de coagulação, floculação e flotação por ar dissolvido e, conseqüentemente, remoção de microcistina contida no interior das células íntegras. A oxidação com cloro realizada após a filtração, bem como a oxidação com a associação do permanganato de potássio e cloro realizada após a flotação, resultaram em eficiência de remoção de microcistina extracelular (microcistina livre no meio líquido) da ordem de $95 \%$, atendendo ao padrão de potabilidade com cocentrações de microcistina menores que $1,0 \mu \mathrm{g} \cdot \mathrm{L}^{-1}$. A oxidação da água bruta com permanganato de potássio associada à oxidação da água flotada com cloro, apresentou o melhor desempenho de remoção de microcistina extracelular, com eficiência superior a $98 \%$. Em todos os ensaios de oxidação química foi constatada a influência da variação do $\mathrm{pH}$ na remoção de microcistina, sendo que o aumento de eficiência foi associado à diminuição dos valores de $\mathrm{pH}$. Foram observados indícios de remoção de trihalometanos pela flotação por ar dissolvido e redução da formação de trihalometanos quando a oxidação química foi feita com a associação do permanganato de potássio e cloro.

PALAVRAS CHAVE: Remoção de microcistina; remoção de fitoplancton, flotação por ar dissolvido; oxidação química com permanganato de potássio e cloro; remoção e formação de trihalometanos. 


\section{ABSTRACT}

PEREZ, M. F. (2008). Removal of Phytoplankton and Microcystin from Source Water, by Assotiation of Dissolved Air Flotation and Chemical Oxidation with Potassium Permanganate and Chlorine. São Carlos, 2008. 254 p. Tese (Doutorado) - Escola de Engenharia de São Carlos da Universidade de São Paulo.

The aim of this research was to study the phytoplankton and microcystin removal at different treatment conditions, all based in coagulation, flocculation, dissolved air flotation and filtration, complemented by chemical oxidation applied at different points of the basic treatment sequency. The lab scale experiments was conduted with raw water prepared by a mixture of natural water, collected in Barra Bonita Reservoir at São Paulo State, Brazil, and a high concentrated Microcystis culture prepared in laboratory. The microcystin concentration in raw water was kept in a range of 14 to $17 \mu \mathrm{g} \cdot \mathrm{L}^{-1}$. Ferric chloride was used as coagulant, and, potassium permanganate and chlorine (sodium hypochlorite) were used as oxidants. The results showed phytoplankton removal efficiency about $99,9 \%$ by the sequency of coagulation, flocculation and dissolved air flotation, resulting a great removal of microcystin retained into the whole cells. The chlorine oxidation after filtration, as well as the oxidation with potassium permanganate and chlorine after dissolved air flotation, resulted in a microcystin removal of about $95 \%$ and concentrations under the World Health Organization drinking water guideline value of $1,0 \mu \mathrm{g} \cdot \mathrm{L}^{-1}$. The raw water potassium permanganate oxidation associated with the chlorine oxidation after flotation, leaded to the best results concerning microcystin removal, with efficiency above $98 \%$. All experimental conditions with chemical oxidation showed a relevant effect of the $\mathrm{pH}$ on the microcystin removal, the decrease of $\mathrm{pH}$ values contributed to the increase of microcystin removal. It was observed signs of THM's removal by the dissolved air flotation and reduction of THM's production when the chemical oxidation took place with the association of potassium permanganate and chlorine.

KEYWORDS: Microcystin removal; phytoplankton removal; dissolved air flotation; potassium permanganate oxidation; chlorine oxidation; THM's production; THM's removal. 


\section{1 - INTRODUÇÃO E JUSTIFICATIVA}

O crescimento desordenado da maioria dos grandes centros urbanos brasileiros e a conseqüente ocupação indevida das áreas de proteção de mananciais, tem resultado em crescente degeneração da qualidade das águas dos mananciais superficiais e subterrâneos.

No caso específico dos lagos naturais e artificiais, que freqüentemente são utilizados para usos múltiplos, incluindo, principalmente, produção de energia elétrica e produção de água potável para o abastecimento público, as atividades domésticas, industriais e agrícolas desenvolvidas irregularmente no entorno desses mananciais resultam no aporte de cargas diretas e difusas, que comprometem a qualidade de suas águas, notadamente devido à grande quantidade de nutrientes que aumentam significativamente o seu potencial de eutrofização.

Dependendo das características físicas e hidrodinâmicas desses mananciais lacustres, a intensa floração de algas é freqüente quando não existe limitação da disponibilidade de nutrientes. Nessas condições, é estabelecido significativo desequilíbrio ecológico no corpo d'água, tendo como um dos resultados diretos e imediatos o aumento do risco sanitário do uso dessas águas e, conseqüentemente, da dificuldade de sua exploração para fins de produção de água potável.

A excessiva presença de algas na água bruta captada nos mananciais eutrofizados pode acarretar sérios problemas operacionais nas estações de tratamento, com conseqüente queda da qualidade da água produzida, tornando-a imprópria para o consumo, e/ou ocasionando gastos excessivos relacionados com o consumo de água para lavagem dos filtros e de produtos químicos. Quando a floração de 
microrganismos fitoplanctônicos é associada especificamente ao grupo das cianobactérias, os problemas são agravados devido à capacidade de determinadas espécies produzirem potentes substâncias tóxicas denominadas cianotoxinas.

Segundo a Organização Mundial da Saúde (WHO, 1999), são registrados inúmeros casos de envenenamento fatal de animais silvestres e de criação relacionados a cianotoxinas. Não existem registros de casos fatais relacionados a seres humanos decorrentes da ingestão de água contaminada com essas substâncias, mas sim decorrentes de intoxicação por via venosa, devido ao uso de água contaminada em seções de diálise em pacientes com problemas renais. Portanto, em seres humanos casos agudos são raros e relacionados a condições restritas de uso de água contaminada, entretanto, intoxicações crônicas, com o desenvolvimento de tumores no fígado, são recorrentes em condições de consumo prolongado ou freqüente de águas contaminadas com cianotoxinas.

A ocorrência de florações de algas em reservatórios brasileiros explorados para fins de abastecimento público tem sido muito freqüente, sendo que a problemática das florações associadas a cianobactérias tóxicas atingiu grande repercussão nacional em 1996, devido ao fato ocorrido na cidade de Caruaru no estado de Pernambuco. Segundo Azevedo ${ }^{1}$ apud CALIJURI et al (2006), 123 pacientes de uma clínica de hemodiálise tiveram quadro clínico indicativo de síndrome de intoxicação hepática, sendo que 60 pacientes morreram. A investigação revelou que a intoxicação foi causada pela água utilizada para as seções de hemodiálise, que estava contaminada por cianotoxinas.

\footnotetext{
${ }^{1}$ AZEVEDO, S. M. F. O. (1998) Toxinas de cianobatérias: Causas e Consequiências para a Saúde Pública. Medicina on Line, V. 1 nº 3 , Jul/Ago/Set.
} 
Recentemente, destacam-se também as ocorrências de florações nos reservatórios Billings e Guarapiranga, responsáveis por parte do abastecimento da Região Metropolitana de São Paulo. Embora ainda sem registros de ocorrência de cianotoxinas nesses eventos, foram confirmados problemas operacionais relacionados com a excessiva presença de algas e a conseqüente redução da capacidade de produção de água potável, comprometendo ainda mais o abastecimento de uma região carente na oferta de água potável.

Vale salientar, ainda, que, atualmente, uma das maiores preocupações relacionadas a cianotoxinas diz respeito aos mecanismos de toxicidade crônica, tais como lesões no fígado por efeito acumulativo de cianotoxinas e produção de tumores devido a microcistina, em situações de exposição prolongada ou freqüente através de ingestão de água contaminada (WHO, 1999 e CALIJURI et al, 2006).

As microcistinas são capazes de permanecer por meses no meio líquido, quando da ausência de microrganismos capazes de degradá-las. Mesmo com a presença destes, o processo de decomposição dessas substâncias pode levar semanas devido ao período de adaptação dos decompositores. De acordo com AWWA (1995), a microcistina pode persistir na água tempo suficiente para passar pelos sistemas de captação, tratamento, armazenamento e distribuição, representando assim, enorme risco de intoxicação associada ao abastecimento público de água potável, caso não seja conferido tratamento apropriado para remoção dessa toxina.

Portanto, as cianobactérias constituem hoje, não só no Brasil, como no mundo, sério problema de saúde pública, que acarreta crescente preocupação por parte de técnicos e pesquisadores da área de tratamento de água para abastecimento. 
Com o objetivo de prevenir e controlar a presença de cianotoxinas na água distribuída à comunidade, a atual Portaria 518 de 25/03/2004, do Ministério da Saúde, estabelece como padrões de potabilidade de água o limite de $1,0 \mu \mathrm{g} \cdot \mathrm{L}^{-1}$ para microcistinas e recomenda concentrações limites de $3,0 \mu \mathrm{g} \cdot \mathrm{L}^{-1}$ para saxitoxina e 15 $\mu \mathrm{g} . \mathrm{L}^{-1}$ para cilindrospermopsinas. Essas toxinas são descritas no capítulo 3 (item $3.2)$.

A revisão dos padrões de potabilidade com a inclusão de concentrações limites de cianotoxinas é uma significativa evolução para um controle mais rigoroso e seguro da qualidade das águas captadas em mananciais com potencial de eutrofização. No entanto, trata-se apenas de medida de cunho legal que deve ser acompanhada da evolução e disponibilização de técnicas laboratoriais dedicadas à detecção dessas toxinas de forma segura e simplificada, bem como do aprofundamento das pesquisas visando o desenvolvimento de novas tecnologias e o incremento das tecnologias de tratamento de água existentes, para a remoção dessas cianotoxinas.

Desde meados do ano de 2003, sob a orientação do Prof. Dr. Marco Antônio Penalva Reali, uma equipe formada por um aluno de iniciação científica, quatro mestrandos e um doutorando tem realizado trabalhos de pesquisa que envolvem o estudo do emprego de técnicas convencionais de tratamento de água associadas à adsorção em carvão ativado e oxidação química para a remoção de cianobactérias e microcistina.

Até o presente foram concluídas três dissertações de mestrado e um trabalho de iniciação científica, cujos resultados e experiências adquiridas com os procedimentos metodológicos adotados, constituem parte importante da base desta tese de doutorado, que envolveu a flotação por ar dissolvido e a investigação da 
oxidação química com utilização de diferentes agentes oxidantes e distintos locais de aplicação dos mesmos, de forma a constituir "barreiras múltiplas" destinadas à remoção de cianobactérias e microcistina em sistemas de tratamento de água. 


\section{2 - OBJETIVOS}

Avaliar a eficiência de remoção de fitoplancton e microcistina, a influência da variação do $\mathrm{pH}$ na etapa de oxidação final com cloro, bem como a formação e remoção de trihalometanos, nos seguintes fluxogramas de tratamento de água de estudo contendo elevada concentração de fitoplancton e microcistina:

- Coagulação, floculação, flotação por ar dissolvido, filtração e pós-oxidação com cloro;

- Coagulação, floculação, flotação por ar dissolvido e inter-oxidação com permanganato de potássio;

- Coagulação, floculação, flotação por ar dissolvido e inter-oxidação com a associação de permanganato de potássio e cloro;

- Pré-oxidação com permanganato de potássio, coagulação, floculação, flotação por ar dissolvido e pós-oxidação com cloro;

- Pré-oxidação com a associação de permanganato de potássio e cloro, coagulação, floculação, flotação por ar dissolvido e pós-oxidação com cloro. 


\section{3 - REVISÃO DE LITERATURA}

\subsection{Cianobactérias}

As cianobactérias, de acordo com o sistema de classificação dos seres vivos em cinco reinos, pertencem ao reino Monera, também conhecido como Prokaryotae.

Os organismos que compõem este reino são unicelulares, não possuem núcleo verdadeiro, nem organelas envolvidas por membrana e se reproduzem principalmente por divisão binária (BLACK, 2002).

Ficologistas classificam as cianobactérias como algas devido à presença de pigmentos e pela maior semelhança de seus mecanismos fotossintéticos com algas verdadeiras do que com bactérias. Porém esses microrganismos diferenciam-se das demais algas devido à ausência de núcleo individualizado, com seus pigmentos difundidos na massa citoplasmática, característica de bactérias (BRANCO, 1978; AWWA, 1995; WHITTON e POTTS, 2000). As cianobactérias apresentam alta diversidade morfológica, podem ter formato tendendo ao esférico; Microcystis $s p$, Choroococcus sp ou filamentosas; Anabaena sp, Oscillatoria sp e Lyngbya sp, e podem ocorrer individualmente ou agrupadas em colônias.

Segundo CALIJURI et al (2006), tradicionalmente, a classificação das cianobactérias segue a nomenclatura botânica e por isso são conhecidas também como algas azuis ou Cyanophyceae. Entretanto, os critérios da nomenclatura botânica são criticados por diversos autores e atualmente estão sofrendo revisões para incluir esse grupo de microrganismos na nomenclatura bacteriológica, que utiliza, além de critérios morfológicos, critérios bioquímicos, genéticos, fisiológicos e ecológicos. A revisão 
em andamento pretende preservar os nomes dos grupos já consagrados, porém, mudanças na taxonomia das cianobactérias são previstas para os próximos anos.

As estratégias de sobrevivência das cianobactérias foram bem sucedidas ao longo do tempo. Especialistas datam seu surgimento há 3,5 bilhões de anos, portanto, desde que surgiu vida na Terra. Adaptações fisiológicas, bioquímicas, genéticas e reprodutivas garantiram a existência dessas espécies nos mais variados ambientes: terrestres, marinhos, lacustres e em ambientes úmidos (paredes, telhados, rochas, cascas de árvores etc.). Elas desempenharam importante papel na evolução produziram grande quantidade de oxigênio há 1,5 bilhões de anos e isto favoreceu 0 surgimento de outras espécies (SCHOPF, 2000).

Segundo CALIJURI et al (2006), as cianobatérias se reproduzem de forma assexuada, como nas bactérias, a divisão ocorre por crescimento e invaginação da parede celular e a reprodução acontece por fissão binária ou múltipla. Os conteúdos celulares e o nucleóide também são multiplicados, não se dividindo por mitose, como ocorre com protistas e outros organismos eucariontes. Em algumas cianobatérias a reprodução também pode ocorrer por brotamento e fragmentação.

Em termos de mobilidade, as cianobactérias não possuem cílios ou flagelos como as bactérias. Conseqüentemente, toda a locomoção é baseada na expulsão de material orgânico celular, por deslizamento no caso de espécies filamentosas ou por rotação. Outra característica das cianobactérias é a presença de vacúolos gasosos, que promovem o controle de sua flutuabilidade, importante mecanismo por permitir a migração vertical em função da disponibilidade de luz e nutrientes. BROOKES et al (2000) verificaram que variações do volume das vesículas gasosas e da atividade do metabolismo celular contribuem para sua flutuabilidade nos ecossistemas naturais. 
Algumas espécies dos gêneros Anabaena, Aphanizomenon, Gloeothece, Lyngbya, Oscillatoria, Plectonema e Nostoc são capazes de fixar nitrogênio atmosférico. Normalmente elas fixam nitrogênio atmosférico por células diferenciadas denominadas heterocistos. Assim, a ausência do nitrogênio na água não é fator limitante para o desenvolvimento dessas cianobactérias (AWWA, 1995).

As cianobactérias possuem, além da clorofila-a, outros pigmentos protéicos denominados ficobilinas. Um desses pigmentos, a ficocianina, absorve comprimentos de onda de luz na banda vermelha do espectro e reflete na banda azul, sendo que a combinação do visual verde-azulado da ficocianina e o verde da clorofila-a, cria a aparência azul esverdeada característica desses microrganismos, fato pelo qual também são conhecidos pela denominação de algas azuis.

Tendo em vista a capacidade de absorver a luz em diferentes comprimentos de onda, ou seja, o comprimento de onda na banda azul devido à clorofila-a e o comprimento de onda na banda vermelha devido à ficocianina, a cianobactéria tem vantagem ecológica no ambiente aquático, pois pode utilizar a luz que penetra até camadas mais profundas (banda vermelha) e nas camadas mais rasas (banda azul).

Segundo CALIJURI et al (2006), a nutrição das cianobactérias é relativamente simples, sem a necessidade de vitaminas ou co-fatores de crescimento, porém, pode ocorrer a fotoassimilação de substâncias simples, como glicose e acetato. A maioria desses microrganismos é fototrófica obrigatória, porém, alguns grupos filamentosos podem crescer na ausência da luz, utilizando substâncias orgânicas como fonte de carbono e energia. 
Observa-se também que algumas linhagens de cianobactérias podem ter a capacidade de produção de toxinas, denominadas cianotoxinas, conforme descrito no item 3.2.

\section{2 - Cianotoxinas}

Há grande variedade de cianotoxinas, as quais podem ser classificadas em neurotoxinas, hepatotoxinas e dermatotoxinas. De acordo com sua estrutura química, elas podem ser divididas em três grupos: peptídeos cíclicos, alcalóides e lipopolissacarídeos (SIVONEN e JONES, 1999).

Os peptídeos cíclicos são biomoléculas que podem conter desde dois a dezenas de fragmentos de aminoácidos, sendo que esses aminoácidos são unidos entre si por meio de ligações peptídicas.

Segundo CALIJURI et al (2006), os alcalóides pertencem a um grupo heterogêneo de substâncias orgânicas, cujo ponto em comum é a presença de nitrogênio na forma de amina e, raramente, na forma de amida. Existem várias formas de alcalóides, geralmente com alguma ação fisiológica sobre o sistema nervoso central e, com menos freqüência, ação hepática ou dermatológica.

Os lipopolissacarídeos são formados por sacarídeos e por lipídio A, este último uma endotoxina. Esses compostos estão presentes na composição da parede das células de organismos procariontes e bactérias gram-negativas, pois também são constituintes de sua parede celular. O lipídio A é um glicofosfolipídeo cujo papel é participar dos mecanismos de patogenicidade em células bacterianas gramnegativas, sendo considerado um antígeno fraco, a não ser quando presente em doses elevadas, pois não utiliza mecanismos enzimáticos para danificar as células. 
Estas toxinas podem ser encontradas nas células das cianobactérias ou dissolvidas na água. A toxina presente no material celular pode ser liberada ao meio quando da lise das células. Alguns pesquisadores sugerem que as cianobactérias também podem liberar toxinas em situações de estresse, como mecanismo de defesa ou competição no meio ambiente.

Com o objetivo de prevenir e controlar a presença de cianotoxinas na água distribuída à comunidade, na Portaria 518 de 25/03/2004, do Ministério da Saúde está estabelecido o limite máximo de 1,0 $\mu \mathrm{g} \cdot \mathrm{L}^{-1}$ para microcistinas, sendo aceitável o limite de até $10 \mu \mathrm{g} \cdot \mathrm{L}^{-1}$ em três amostras consecutivas ou não, nas análises realizadas em período de doze meses. A citada portaria recomenda que sejam incluídas análises para a determinação de saxitoxinas e cilindrospermopsinas cujas concentrações limites são respectivamente iguais a $3,0 \mu \mathrm{g} \cdot \mathrm{L}^{-1}$ e $15 \mu \mathrm{g} \cdot \mathrm{L}^{-1}$.

A revisão dos padrões de potabilidade com a inclusão de concentrações limites de cianotoxinas é uma significativa evolução para um controle mais rigoroso e seguro da qualidade das águas captadas em mananciais com potencial de eutrofização. No entanto, trata-se apenas de uma medida de cunho legal que deve ser acompanhada de uma evolução e disponibilização de técnicas laboratoriais dedicadas à detecção dessas toxinas de forma segura e simplificada, bem como do aprofundamento das pesquisas visando o desenvolvimento de novas tecnologias e o incremento das tecnologias de tratamento de água existentes, para a remoção dessas cianotoxinas.

\subsection{1 - Neurotoxinas}

As toxinas que causam problemas neurológicos podem ser divididas em três famílias, anatoxina-a, anatoxina-a (s) e saxitoxinas. São produtoras de anatoxina-a: 
Anabaena, Oscillatoria e Aphanizomenon, de anatoxina-a (s): Anabaena, e de saxitoxinas: Aphanizomenon, Anabaena, Lyngbya e Cylindrospermopsi.

De acordo com CARMICHAEL (1994), as anatoxinas-a e anatoxinas-a (s) afetam a comunicação entre os neurônios e as células musculares, conforme ilustrado na figura 3.1. Em condições fisiológicas normais, a acetilcolina, um hormônio neurotransmissor, liga-se aos seus receptores provocando a troca iônica necessária à indução da contração muscular; posteriormente, a acetilcolinesterase degrada a acetilcolina prevenindo uma superestimulação das células musculares. Por não ser degradada pela acetilcolinesterase, a anatoxina-a liga-se irreversivelmente aos receptores de acetilcolina, o que a torna um bloqueador neuromuscular. A anatoxina-a (s), por sua vez, inibe a ação da acetilcolinesterase e, assim, impede a degradação da acetilcolina ligada aos seus receptores. A conseqüência é a superestimulação muscular.

Por sua vez, as saxitoxinas interrompem a comunicação entre neurônios e células musculares, impedindo a troca iônica, conforme ilustrado na figura 3.2.

Os sintomas da contaminação por neurotoxinas são: desequilíbrio, fasciculação muscular, respiração ofegante, convulsões e até morte do animal, o que acontece em poucos minutos ou poucas horas após a ingestão (CARMICHAEL, 1994). Essa sintomatologia é bastante semelhante à provocada por outros intoxicantes, tais como os metais pesados. 

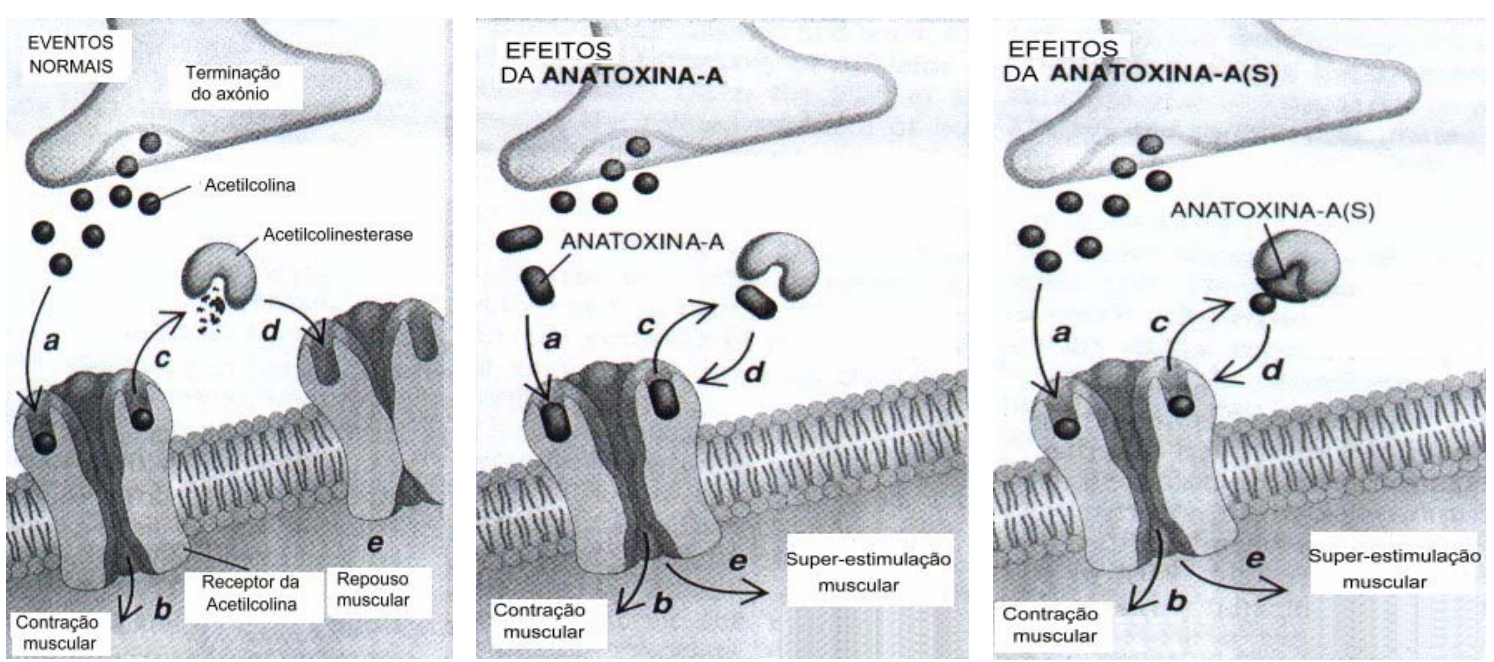

Figura 3.1 - Efeitos da antoxina-a e da antoxina-a(s) na contração muscular.

FONTE: Adaptado de Carmichael (1994)

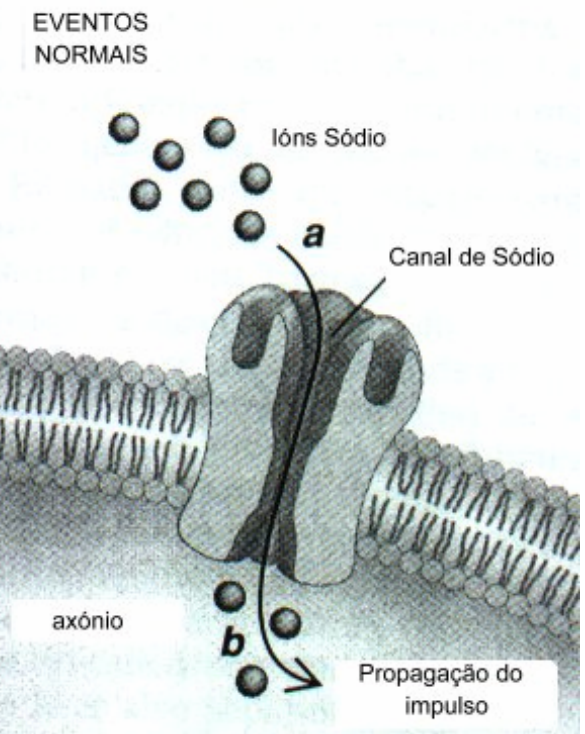

$$
\text { EFEITOS DA SAXITOXINA }
$$

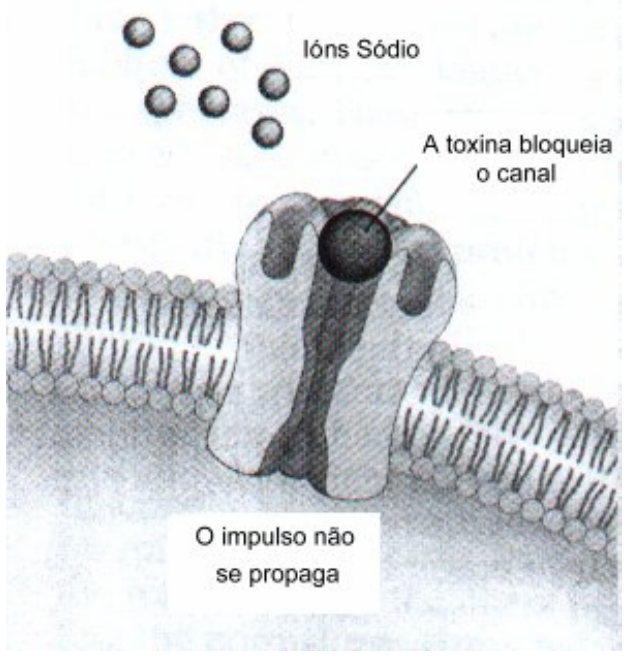

Figura 3.2 - Efeitos da saxitoxina na propagação do impulso nervoso.

FONTE: Adaptado de Carmichael (1994)

\subsection{2 - Hepatotoxinas}

Apesar da letalidade das neurotoxinas ser maior, as hepatotoxinas compõem o mais importante e o grupo de cianotoxinas mais freqüentemente encontrado no ambiente aquático; há relatos de contaminação por hepatotoxinas no mundo todo. 
Segundo CARMICHAEL (1994), SIVONEN e JONES (1999), essa toxina é formada por peptídeos cíclicos e pode ser produzida pelos gêneros Anabaena, Microcystis, Oscillatoria, Nostoc, Anabaenopsis, Hapalosiphon (gênero terrestre), Cylindrospermopsis e Nodularia.

Segundo SIVONEN e JONES (1999), esses peptídeos cíclicos são compostos naturais de elevado peso molecular. Se o peptídeo cíclico possuir cinco aminoácidos, a toxina é denominada nodularina e se possuir sete aminoácidos é denominada microcistina, conforme ilustrado na figura 3.3.

A nomenclatura usada refere-se à Microcystis e à Nodularia, porque estas toxinas primeiramente foram encontradas nesses microrganismos. As hepatotoxinas em geral são solúveis em água, entretanto existem algumas microcistinas de características hidrofóbicas que são capazes de penetrar em membranas lipídicas de animais e células de plantas e bactérias.

TEIXEIRA e ROSA (2006) confirmam que as microcistinas são compostos hidrofóbicos com uma carga ligeiramente negativa em uma faixa de pH de 6 a 9 e possuem peso molecular variando de 909 a $1115 \mathrm{~g} \cdot \mathrm{mol}^{-1}$, mais precisamente, 994 g.mol ${ }^{-1}$ no caso da microcistina LR. 


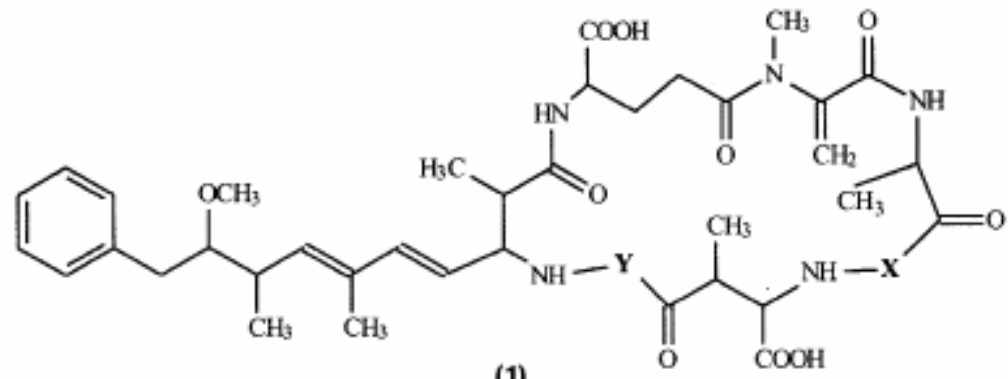

(1)

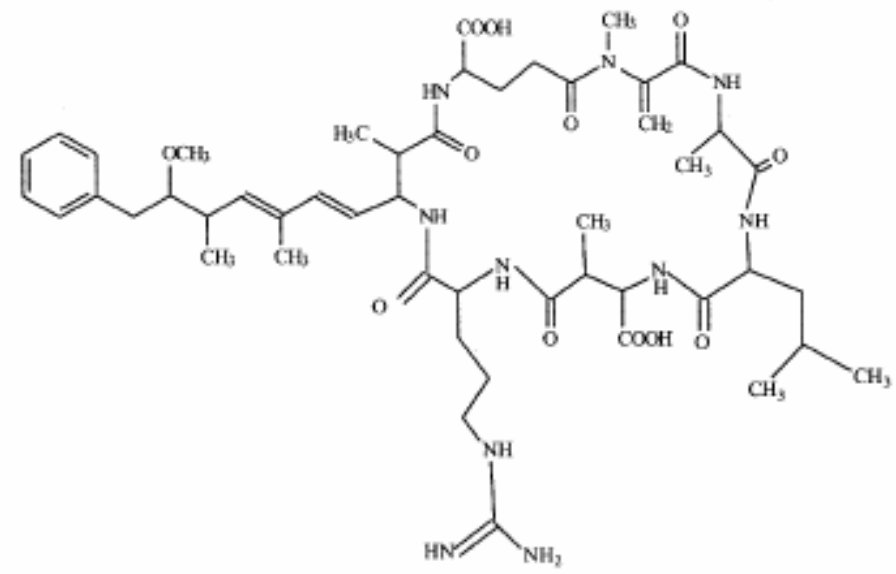

(2)

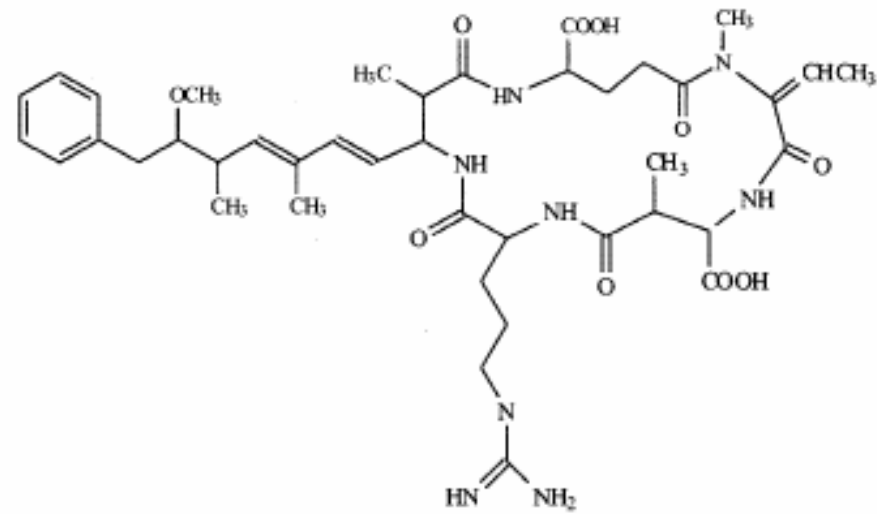

(3)

Figura 3.3 - Estrutura química de hepatotoxinas: (1) Estrutura geral das microcistina, (2) Estrutura geral das nodularinas e (3) Estrutura da cilindrospermopsina. FONTE: Sivonen e Jones (1999) 
Na figura 3.3, observa-se que na estrutura química da microcistina $X$ e $Y$ são amino ácidos que variam de acordo com o tipo de microcistina, por exemplo: no caso da microcistina LR, $X$ representa a Leusina e o $Y$ representa a Arginina.

As hepatotoxinas, ao atingirem o citoesqueleto dos hepatócitos por meio dos receptores dos ácidos biliares, causam sua desorganização, o que provoca retração dos mesmos com conseqüente aumento dos espaços intercelulares. Esta toxina faz, também, com que as células dos capilares sinosoidais retraiam-se; com isso o sangue passa a fluir dos capilares para os espaços intercelulares formados, o que provoca lesões no fígado, segundo ilustrado na figura 3.4 (CARMICHAEL, 1994).

Segundo CARMICHAEL (1994), as microcistinas são potentes inibidores das enzimas conhecidas como proteínas fosfatase que, em conjunto com outras enzimas, as proteínas quinases, regulam 0 mecanismo de fosforilação e desfosforilação das proteínas, importantes para a divisão celular. A inibição das fosfatases bloqueia o mecanismo de fosforilação e desfosforilação, o que favorece maior proliferação celular. Portanto, em doses não letais as hepatotoxinas podem ser carcinogênicas. 

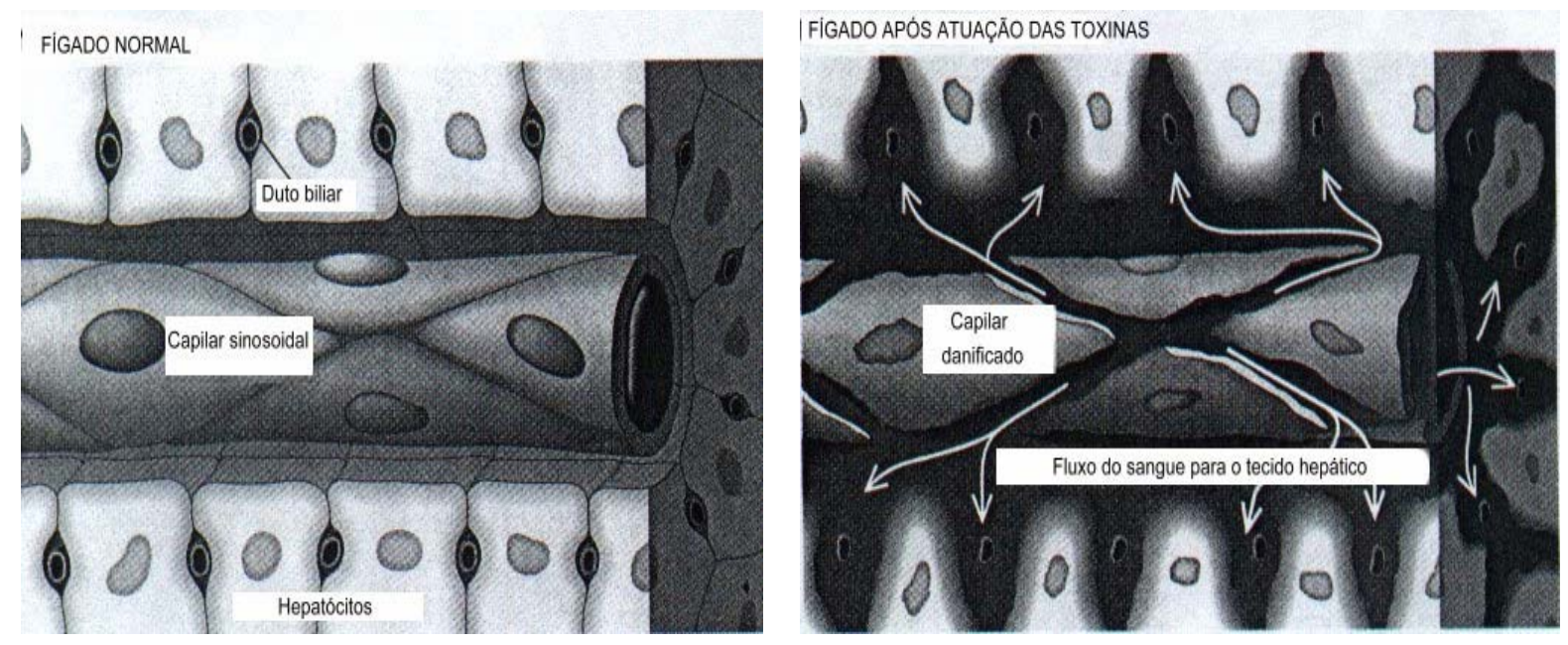

Figura 3.4 - Efeitos das hepatotoxinas no fígado

FONTE: Adaptado de Carmichael (1994)

\subsection{3 - Dermatotoxinas}

As dermatotoxinas são compostos tóxicos do grupo dos lipopolissacarídeos, integrantes da parede celular de todos os gêneros de cianobactérias e de algumas bactérias. A estrutura química dessas substâncias ainda é pouco conhecida.

Essas substâncias irritantes ao contato com a pele são menos tóxicas que as hepatotoxinas e neurotoxinas apresentadas nos itens anteriores. O contato direto com a dermatotoxina pode causar vermelhidão e lesões na pele, irritação nos olhos, conjuntivite, urticária, obstrução nasal e asma.

Na tabela 3.1, é apresentado um resumo das cianotoxinas e respectivos gêneros de cianobactérias produtoras, bem como o alvo primário em mamíferos. 
Tabela 3.1 - Cianotoxinas, alvo primário em mamíferos e principais gêneros responsáveis pela produção das mesmas.

\begin{tabular}{lll}
\hline \hline Grupo da Toxina & Alvo primário em mamíferos & Principais gêneros produtores \\
\hline \hline Peptídeos cíclicos & & \\
\hline Microcistina & Fígado & Microcystis sp., Anabaena sp., Planktothrix sp., (Oscillatoria sp.,) , Nostoc sp., \\
& & Hapalosiphon sp., Anabaenopsis sp. \\
\hline Nodularina & Fígado & Nodularia sp. \\
\hline Alcalóides & & \\
\hline Anatoxina - a & Nervo sináptico & Anabaena sp., Planktothrix sp., (Oscillatoria sp.,) Aphanizomenon sp. \\
\hline Anatoxina - a (s) & Nervo sináptico & Anabaena sp. \\
\hline Aplisiotoxina & Pele & Lyngbya sp., Schizothrix sp., Planktothrix sp., (Oscillatoria sp.,) \\
\hline Cilindrospermopsina & Fígado & Cylindrospermopsis sp., Aphanizomenon sp., Umezakia sp. \\
\hline Lyngbyatoxina - a & Pele e trato gatrointestinal & Lyngbya sp. \\
\hline Saxitoxina & Nervo axônico & Anabaena sp., Aphanizomenon sp., Lyngbya sp., Cylindrospermopsis sp. \\
\hline Lipopolissacarídeos & & \\
\hline (LPS) & Qualquer contato. & Todos \\
\hline \hline
\end{tabular}

Fonte: CALIJURI et al (2006). 
$\mathrm{Na}$ tabela 3.2, é apresentada uma comparação entre toxinas produzidas por cianobactérias e outras toxinas conhecidas.

Tabela 3.2 - Toxicidade de diversas toxinas conhecidas

\begin{tabular}{|c|c|c|}
\hline Toxina & Produtor & $\mathrm{DL}_{50}\left(\mu \mathrm{g} . \mathrm{kg}^{-1}\right)\left(^{*}\right)$ \\
\hline Botulínica & Clostridium botulinum & 0,00003 \\
\hline Tetanospamina & Clostridium tetani & 0,0001 \\
\hline Diftérica & Corynebacterium diphteriae & 0,3 \\
\hline Tetrotoxina & 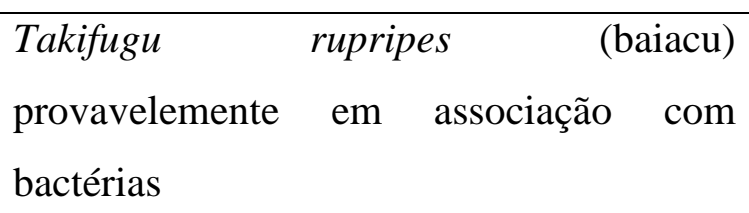 & 8 \\
\hline Saxitoxina & $\begin{array}{l}\text { Várias espécies de dinoflagelados e } \\
\text { cianobactérias }\end{array}$ & 9 \\
\hline Ofídica & Crotalus durissus (cascavel) & 18 \\
\hline Anatoxina - a (s) & Cianobactérias & $20-40$ \\
\hline Nodularina & Cianobactérias & $30-50$ \\
\hline Microcystina - LR & Cianobactérias & 50 \\
\hline Anatoxina - a & Cianobactérias & 200 \\
\hline Paration & Defensivo agrícola & 3.550 \\
\hline
\end{tabular}

$\left({ }^{*}\right)$ - Quantidade necessária expressa em $\mu \mathrm{g} \cdot \mathrm{kg}^{-1}$ de peso corpóreo para provocar a morte de $50 \%$ de um lote de animais submetido ao bioensaio.

Fonte: CALIJURI et al (2006).

\subsection{4 - Degradação de Cianotoxinas}

Segundo CALIJURI et al (2006), as cianotoxinas exibem diferenças nas estabilidades químicas e degradação biológica nos sistemas aquáticos. Em pH neutro, as microcistinas são extremamente estáveis, resistentes à hidrólise química e à oxidação. Tanto as nodularinas quanto as microcistinas são resistentes à fervura, mantendo sua toxicidade inalterada. 
SIVONEN E JONES (1999) observaram que em condições naturais as microcistinas resistem por meses ou anos em condições naturais. Segundo HARADA et al (1999), em temperatura superior a $40{ }^{\circ} \mathrm{C}$, pode ocorrer hidrólise em cerca de 10 semanas para $\mathrm{pH}$ de aproximadamente 1,0 , ou 12 semanas para $\mathrm{pH}$ de cerca de 9,0 , quando foi verificada a degradação de cerca de $90 \%$ da concentração inicial de microcistina.

Segundo SIVONEN E JONES (1999), na presença de pigmentos fotossintéticos hidrossolúveis, a degradação fotoquímica de $90 \%$ de concentração total de microcistina pode ocorrer entre 6 a 10 semanas, sendo que a presença de substâncias húmicas pode acelerar esse mecanismo de degradação. Esses pesquisadores também observaram que as microscistinas são suscetíveis à degradação por algumas espécies de bactérias encontradas em ecossistemas aquáticos e efluentes de esgoto. Esse processo de decomposição bacteriana pode reduzir cerca de $90 \%$ da concentração incial em um prazo de 10 a 20 dias dependendo da temperatura da água.

\section{3 - Eutrofização - origem, efeitos e controle}

ESTEVES (1988) define ecologicamente eutrofização como: “ [...] aumento da concentração de nutrientes, especialmente fósforo e nitrogênio, nos ecossistemas aquáticos, que têm como conseqüência o aumento de sua produtividade [...] ". Uma outra definição talvez seja mais aplicável ao saneamento: "Eutrofização é a fertilização do ecossistema com conseqüente produção de biomassa muito maior que aquela que pode ser absorvida e utilizada por uma cadeia de alimentação". (DUARTE, 1982)

Os fatores que promovem as florações de algas tóxicas são, em linhas gerais, os mesmos que promovem os "blooms" da maioria das outras cianofíceas, sendo que a 
identificação dos fatores promotores desse fenômeno tem sido o grande desafio dos pesquisadores, pois embora algumas conclusões genéricas possam ser feitas, ainda não existe um fator ambiental que possa ser identificado como o elemento "chave" para uma segura previsão desse fenômeno.

Segundo CALIJURI et al (2006), observa-se que em decorrência das características fisiológicas e morfológicas das cianobatérias, as mesmas apresentam extraordinária capacidade de adaptação aos mais variados ambientes, constituindo-se, portanto, em excelentes colonizadoras ambientais, o que propiciou grande vantagem ao processo evolutivo em relação aos demais organismos fitoplanctônicos.

Em geral, as condições ambientais que são favoráveis para a floração predominante de cianofíceas são: disponibilidade de nutrientes inorgânicos essenciais tais como o nitrogênio e o fósforo, temperaturas da água na faixa de 15 a $30^{\circ} \mathrm{C}, \mathrm{pH}$ da água na faixa de 6 a 9 ou mais, bem como condições hidrodinâmicas do corpo d'água que favoreçam a sua estratificação vertical. Como citado anteriormente, uma das formas de mobilidade das cianobactérias é o controle de sua flutuabilidade, devido à presença de vacúolos gasosos que são inflados ou esvaziados. Também é importante ressaltar sua pequena sensibilidade em relação à luz, permitindo seu desenvolvimento em uma ampla faixa de intensidade de luz e comprimentos de onda.

Os "blooms" de cianofíceas nos corpos d'água em geral não são formados exclusivamente por uma espécie de alga, mas sim por uma composição de determinados gêneros ou espécies que podem ser ou não ser de linhagem tóxica.

A literatura disponível indica que as cianobactérias ou cianofíceas respondem distintamente para cada condição ambiental específica, tais como luz, temperatura, 
$\mathrm{pH}$, nutrientes, etc., e pouco pode ser concluído com relação à influência desses fatores ambientais na produção de toxinas.

Segundo a AWWA (1995), a concentração de toxinas em um determinado evento de bloom pode oscilar em função de vários fatores ambientais, tais como luz, temperatura, nitrogênio, bem como em função do estado fisiológico da cianobatéria responsável pelo bloom, sendo que quando esse fenômeno é caracterizado por dois microrganismos competidores a toxicidade aumenta, sugerindo que a produção de toxinas e sua liberação para o meio líquido pode ser mais um dos eficientes mecanismos de competição das linhagens tóxicas de cianobactérias. Segundo CALIJURI et al (2006), as causas para a produção de cianotoxinas ainda não são bem esclarecidas, mas pesquisadores acreditam que essas substâncias desempenham funções protetoras contra espécies zooplanctônicas, seus predadores primários, como fazem algumas plantas vasculares ao produzirem taninos, fenóis, alcalóides ou esteróides. Outros pesquisadores acreditam que a produção de cianotoxinas está relacionada às condições de crescimento ou à competição por recursos.

HOEGER et al (2004), observaram em lagos australianos que as concentrações mais elevadas de cianotoxinas não estavam diretamente relacionadas com as contagens de células mais elevadas, ao contrário, os níveis de toxinas aumentavam na fase de crescimento exponencial, quando havia competição entre as cianobactérias Microcystis aeruginosa e Anabaena circinalis, visando a posição dominante no ambiente aquático. Depois da predominânia de Microcystis aeruginosa, ocorreu redução da concentração de microcistina a níveis não detectáveis. 
A eutrofização do ambiente aquático, quer seja por algas ou cianobatérias, pode causar diversos efeitos negativos na água, destacando-se:

- Decréscimo da concentração de oxigênio dissolvido, consumido por bactérias decompositoras da matéria orgânica.

- Alterações do meio, tais como bloqueio dos raios solares, alteração do pH da água, alteração da razão nível de $\mathrm{O}_{2} / \mathrm{CO}_{2}$, que podem dificultar o desenvolvimento de outras espécies.

- Alterações das características organolépticas da água, pela produção de compostos aromáticos voláteis que, por contato ou ingestão, apesar de não causarem agravos à saúde pública, conferem à água sabor e odor desagradáveis.

- Produção de toxinas que podem causar o envenenamento de diversos animais, inclusive o homem.

Vários métodos de controle de florações têm sido aplicados e avaliados, com diferentes graus de sucesso, por diversos pesquisadores em todo o mundo. As ações de controle preventivo, que obviamente são as mais racionais, são baseadas em vários procedimentos tais como:

- gerenciamento da bacia hidrográfica e do próprio manancial com o objetivo de minimizar os aportes de nutrientes essenciais ao desenvolvimento das algas e cianobactérias ,

- técnicas de alteração das condições químicas e hidrodinâmicas do reservatório tais como aeração para quebra de estratificação vertical da coluna líquida,

- controles biológicos tal como a biomanipulação para alterar a estrutura da comunidade existente no reservatório e, dessa forma, criar condições de competividade que desfavoreçam o desenvolvimento das algas e cianobactérias,

- gerenciamento das descargas de água, no caso de reservatórios artificiais, visando criar condições hidrodinâmicas favoráveis para a quebra de estratificações da coluna líquida, 
- operações de remoção física das algas e cianobatérias, tais como a remoção superficial de escumas.

O controle químico através da aplicação de algicidas, tais como o sulfato de cobre ou permanganato de potássio, somente pode ser considerado uma técnica de prevenção, ou seja, quando empregada antes que o crescimento das cianobactérias atinja proporções de florações. Caso contrário, esse controle será pouco efetivo e certamente aumentará a concentração de toxinas liberadas para o meio líquido, em decorrência da lise celular causada pelos algicidas.

No parágrafo primeiro do artigo 19 da Portaria 518 de 25/03/2004, é vedado o uso de algicidas para o controle do crescimento de cianobactérias, ou qualquer intervenção no manancial que provoque a lise celular desses microrganismos, quando a densidade de cianobactérias exceder 20.000 cel. $\mathrm{mL}^{-1}\left(2 \mathrm{~mm}^{3} \cdot \mathrm{L}^{-1}\right.$ de biovolume), sob pena de comprometimento da avaliação de riscos à saúde associados às cianotoxinas.

Segundo CALIJURI et al (2006), vários fatores promovem a liberação das cianotoxinas para o meio líquido, como a aplicação de algicidas (sulfato de cobre e sulfato de cloro), o estresse celular decorrente de condições ambientais desfavoráveis e a senescência, que é a morte natural.

\subsection{Métodos de Detecção de Cianotoxinas}

Segundo CALIJURI et al (2006), não é possível determinar se uma proliferação de cianibactérias é tóxica através da simples análise de sua aparência ou identificação de gêneros. A maior dificuldade no estudo das cianotoxinas encontra-se nos métodos disponíveis para a detecção e avaliação de toxicidade. A escolha do método de monitoramento depende das seguintes qualidades: 
- Especificidade: capacidade de identificar a presença de toxinas conhecidas;

- Sensibilidade: capacidade de quantificar valores específicos das diferentes toxinas;

- Precisão: capacidade de quantificar valores absolutos de determinadas toxinas;

- Acurácia: capacidade de estimar quão próximo do valor efetivo está o valor da medida realizada.

Os métodos de detecção de cianotoxinas em águas tiveram origem com os bioensaios em camundongos, utilizados desde o início do século XX. No início da década de 80 métodos de detecção mais sofisticados foram desenvolvidos, como ensaios enzimáticos e métodos analíticos.

\subsubsection{Bioensaios}

Existem diversos métodos biológicos para detecção de cianotoxinas que são baseados na bioatividade das mesmas, testados em ensaios com zooplâncton (Daphnia sp.), bactérias, crustáceos (camarão), camundongos e outros. Segundo CALIJURI et al (2006), dentre todos os organismos utilizados, os bioensaios com camundongos são os mais eficientes.

Geralmente, os bioensaios não possuem suficiente sensibilidade para serem utilizados como medidores para amostras de água com baixa concentração de toxinas - apesar de apresentarem rápida resposta para identificação da toxicidade total de amostras (SWOBODA et al, 1994; HARADA et al, 1999; NICHOLSON et al, 2001).

\subsubsection{Métodos Cromatográficos}

A cromatografia líqüida de alta eficiência (CLAE), em inglês High Performance Liquid Chromatography (HPLC), é o método analítico mais usado para determinação de 
cianotoxinas. Segundo CASS (2001), a cromatografia é um método físico-químico de separação fundamentado na migração diferencial dos componentes de uma mistura devido a diferentes interações entre duas fases imiscíveis - a fase móvel e a fase estacionária. Após a separação das toxinas é realizada a detecção de cianotoxinas pela comparação com padrões de toxinas comercialmente disponíveis.

Após a separação de fases, a detecção das toxinas pode ser feita por absorbância por ultravioleta (UV), fotodiodo (PDA), espectrometria de massa (MS) e outros indicadores (KAYA et al 2001; NICHOLSON e BURCH, 2001; FASTNER et al 2002).

Apesar de sua grande especificidade e sensibilidade, esse método demanda complexos procedimentos de extração da toxina a ser submetida à quantifcação no cromatógrafo, o que pode comprometer sua precisão e acurácia principalmente se as amostras a serem submetidas aos procedimentos de extração tiverem volumes reduzidos (abaixo de $1000 \mathrm{ml}$ ). Portanto, para estudos em escala de bancada, como na Tese em questão, o emprego desse método é dificultado tendo em vista a impossibilidade de coleta de grandes volumes de amostra.

\subsubsection{Ensaios de Inibição de Fosfatase}

As microcistinas podem ser identificadas e quantificadas por seus efeitos inibitórios sobre as proteínas fosfatase dos tipos 1 e 2 (MACKINTOSH e MACKINTOSH, 1994). Para ser aplicado ao monitoramento de água, segundo NICHOLSON e BURCH (2001), este método precisa ser melhor avaliado e comparado a procedimentos mais específicos, como o HPLC. 


\subsubsection{Ensaios Imunológicos}

Técnica analítica baseada em ensaios imunosorbentes ligada à enzima; o nome ELISA é a sigla de Enzyme Linked ImmunoSorbent Assay. Segundo HARADA et al (1999) é um método bastante promissor na detecção de microcistinas por sua alta sensibilidade, especificidade, fácil operação e rapidez de medição.

Os imunoensaios são métodos analíticos que usam anticorpos como reagentes para quantificar substâncias específicas. Estes anticorpos ligam-se fisicamente à amostra através de ligação altamente específica, sendo que esta especificidade permite a detecção da substância pesquisada em amostras complexas mesmo em quantidades mínimas.

No trabalho de pesquisa em questão foi adotado esse método para a medição de microcistina, sendo que a rapidez e simplicidade de determinação, bem como a possibilidade de trabalho com pequenos volumes de amostra (da ordem de 20 microlitros), efetivamente viabilizou os ensaios realizados.

Nesse método a microcistina presente na amostra compete com o conjugado Microcistina-Enzima (peroxidase) por um número limitado de anticorpos ligados à superfície interna das cavidades das placas. O resultado desse teste competitivo pode ser visualizado com o desenvolvimento de cor, sendo que a leitura de intensidade de cor indica, de forma inversamente proporcional, a concentração da toxina analisada. A leitura de cor é feita através de fluorímetro no comprimento de onda de 450nm.

A ilustração 3.5 é apresentada, de forma esquemática, o princípio de competição microcistina-enzima em que se baseia esse método. 


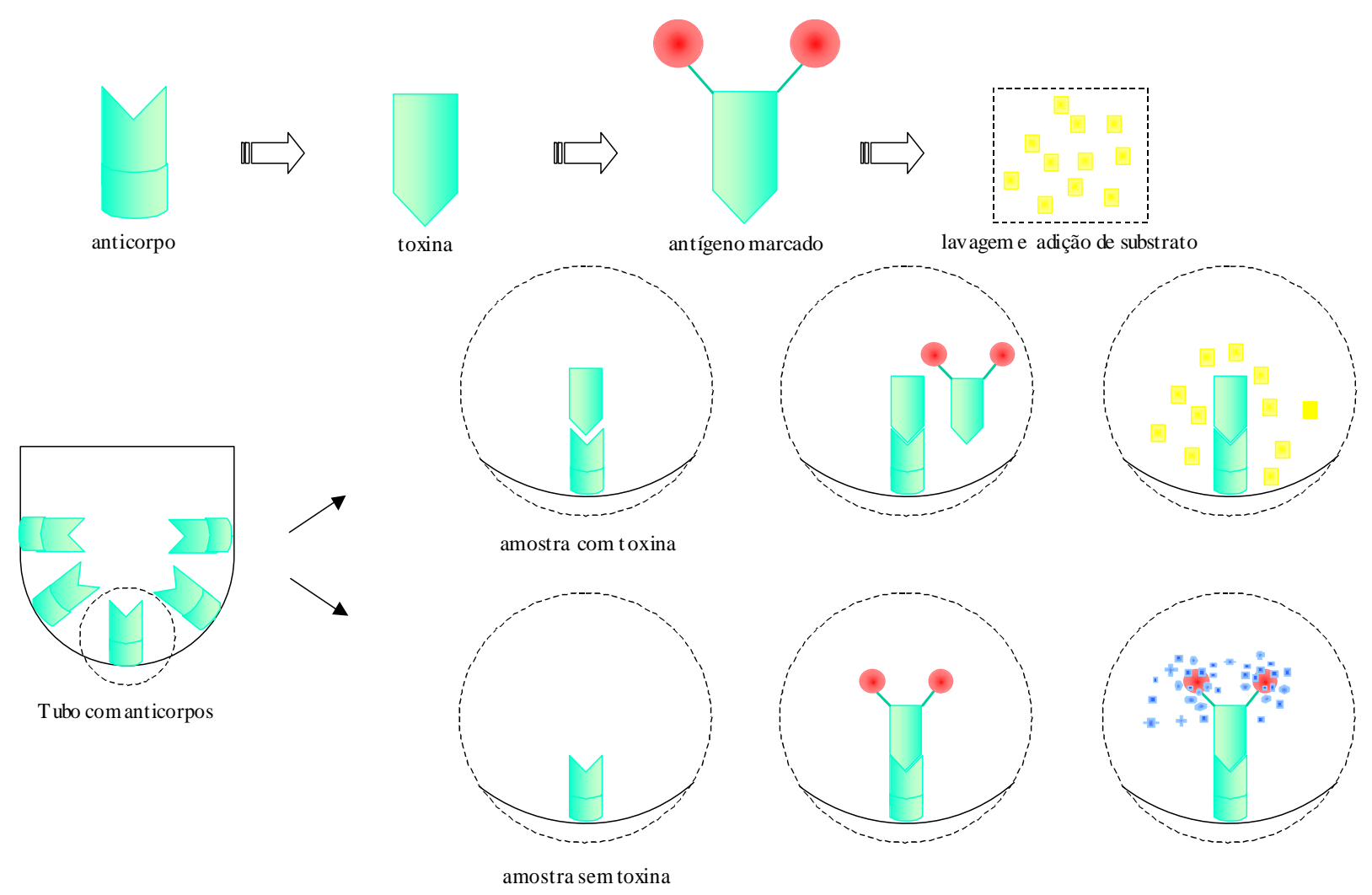

Figura 3.5 - Esquema Ilustrativo do Método ELISA

Fonte: SOVEREIGN do Brasil

Faster et al (2002) compararam métodos de análises de microcistina - HPLC-PDA, HPLC-UV, HPLC-MS, PPA e ELISA - utilizados por 31 laboratórios e concluíram que o método ELISA foi o que apresentou maior reprodutibilidade nos resultados.

\section{4 - A remoção de Cianobactérias e Cianotoxinas nos Sistemas de Tratamento de Água}

REALI et al (1993) e SANTOS (1997) observam a dificuldade da remoção de algas em sistemas convencionais de tratamento de água, sendo que a presença das mesmas, além de conferir sabor e odor às águas de abastecimento, ocasiona uma série de problemas operacionais nas diversas etapas do processo, destacando-se a colmatação precoce dos meios filtrantes. 
A consideração específica de cianobactérias e o inerente potencial de produção de cianotoxinas, torna o problema ainda mais grave, tendo em vista que os processos físico-químicos de coagulação, floculação, sedimentação e filtração também não são efetivos na remoção de toxinas quando dissolvidas no meio líquido.

3.4.1 - O Emprego de Técnicas Convencionais de Tratamento (Coagulação / Floculação / Sedimentação / Filtração)

Segundo DI BERNARDO (1995), a coagulação é a etapa fundamental em uma estação de tratamento de água de ciclo completo, sendo que normalmente as algas possuem carga superficial negativa e demandam aumento da dosagem de coagulante, bem como a utilização de polímeros auxiliares de floculação para melhorar as condições de sedimentação dos flocos formados. Em geral, quando ocorrem florescimentos de algas em mananciais explorados para abastecimento público, a capacidade de produção de água potável nos sistemas de tratamento é reduzida, mesmo com a utilização de auxiliares de floculação, pois os flocos formados são pouco densos e tendem a passar pelos decantadores, sobrecarregando os filtros com a redução significativa de suas carreiras de filtração.

As diferentes fases de crescimento das algas afetam a carga superficial das células e até mesmo a estrutura das suas paredes celulares, dificultando as etapas iniciais de coagulação e floculação. Entretanto, ensaios de tratabilidade criteriosos que visam a otimização dos mecanismos de coagulação por adsorção e neutralização de cargas para a formação de flocos adequados para a filtração direta ou flotação, bem como do mecanismo por varredura para a formação de flocos adequados para a sedimentação, podem contribuir efetivamente para a melhoria das condições de remoção de algas nos processos de tratamento de água. 
HART et al (1997) afirmam que os processos de coagulação, floculação, sedimentação e filtração também podem ser efetivos na remoção de toxinas quando estas estão contidas nas células, indicando, portanto, que o tratamento convencional pode contribuir com a redução de toxinas desde que não ocorra lise celular. Caso contrário, as toxinas são liberadas para o meio líquido, sendo que neste caso apenas com o emprego de dosagens elevadas de oxidante é que será possível a remoção efetiva dessas toxinas.

CHOW et al (1997) estudaram, em escala de laboratório, o efeito da aplicação de cloreto férrico na lise de diversas cianobactérias, segundo dosagens de utilização usual desse coagulante em estações de tratamento de água convencionais (15 a 30 $\left.m g \cdot \mathrm{L}^{-1}\right)$. Em diversas amostras submetidas à dosagem de cloreto férrico e diferentes tempos de contato ( 0 a 24 horas), foram realizadas contagem de células e determinadas concentrações finais de clorofila - a, ficocianina e microcistina, sendo que os resultados não indicaram sinais de lise celular e conseqüente liberação de microcistina para o meio líquido.

Esses mesmos pesquisadores, em 1998, estudaram o impacto, na integridade das células de Microcystis aerugionosa, da energia de mistura da massa líquida usualmente empregada para a coagulação e floculação em sistemas de tratamento de água convencionais de fluxo completo (coagulação/floculação/decantação e filtração). Através da realização de ensaios de bancada em aparelhos de jar-test, não foram verificados sinais de lise celular e conseqüente liberação de microcistina para gradientes de velocidade na faixa de 20 a $550 \mathrm{~s}^{-1}$ e tempos de contato na faixa de 5 minutos a 4 horas. Adicionalmente, observaram que o emprego de sulfato de alumínio como coagulante (cerca de 5,0 mg. $\mathrm{L}^{-1}$ ) também não causou a lise celular e liberação de microcistina (CHOW et al (1998)). 
BERNHARDT e CLASEN (1994) observaram que os mesmos mecanismos que atuam para desestabilizar e flocular partículas inorgânicas podem ser usados para as algas diatomáceas, clorofíceas e cianobactérias, sendo que a efetividade dos diferentes mecanismos de coagulação e floculação estão relacionados com a morfologia das algas. As algas de pequenas dimensões e formato que tendem à esfericidade podem ser desestabilizadas pelo mecanismo de adsorção e neutralização de cargas, enquanto que as algas filamentosas e de maiores dimensões necessitam de maiores dosagens de coagulante para o estabelecimento do mecanismo de varredura. Esses pesquisadores também observaram o potencial de coagulação de algas através de espécies hidrolisadas de alumínio. Para pH da solução igual a 4,0 a formação de espécies hidrolisadas, que são carregadas positivamente, não ocorreu e, conseqüentemente, as algas, naturalmente de carga negativa, não foram neutralizadas. Quando o $\mathrm{pH}$ foi elevado para 5,0 , os pesquisadores verificaram a neutralização de cargas e, dando continuidade à elevação do $\mathrm{pH}$, esses pesquisadores observaram que, para valores de $\mathrm{pH}$ superiores a 5,0 , a elevação da dosagem de alumínio resultou na reversão de cargas, entretanto a coagulação foi bem sucedida, pois a adição de concentrações elevadas de alumínio resultava na formação de precipitados do hidróxido metálico que capturaram as algas através do mecanismo de varredura.

PIETERSE e CLOTO (1997) observaram, mediante trabalho realizado com amostras de água contendo algas coletada no rio Vaal, no Sul da Africa, que os mecanismos de coagulação e floculação das células de algas não são baseados somente nas interações de Van der Waals; a força gravitacional também é um relevante fator de atração que favorece a aglutinação dessas células, bem como das partículas coloidais inorgânicas. Entretanto, no caso específico das algas, a atividade 
fisiológica das mesmas afeta a eficiência total do processo de floculação quando assimilam $\mathrm{CO}_{2}$ ou outros nutrientes, quando produzem $\mathrm{O}_{2}$ e quando excretam substâncias como moléculas orgânicas. Em resumo, o fluxo das substâncias para dentro e fora das células pode criar forças de repulsão ou de atração que irão afetar as interações das células quando agregadas.

Baseados nessas observações, PIETERSE e CLOTO (1997) supuseram que o coagulante a ser usado pode ter relevante influência na coagulação e floculação, porque a adição de cloreto férrico em determinadas culturas de algas pode provocar um estímulo à assimilação de carbono e, conseqüentemente, à produção de $\mathrm{O}_{2}$, levando a uma possível modificação da viscosidade do fluído na proximidade da parede celular das algas que estão colidindo, afetando a aglutinação das mesmas.

\subsection{2 - O Emprego da Flotação por Ar Dissolvido}

O processo de flotação é caracterizado pela separação de sólidos ou líquidos, de uma fase líqüida, pela introdução de pequenas bolhas de ar. Tais bolhas aderem à superfície das partículas, o que aumenta seu empuxo e favorece assim o movimento ascensional dessas partículas em direção à superfície, onde podem ser devidamente coletadas.

Segundo REALI et al (1993), a clarificação de água bruta contendo alta concentração de algas em suspensão (água preparada em laboratório) empregandose uma unidade de flotação em escala de laboratório, apresentou eficiência de remoção de algas superior a 97\% considerando-se velocidades ascensionais de flotação de até $30 \mathrm{~cm} \cdot \mathrm{min}^{-1}\left(430 \mathrm{~m}^{3} \cdot \mathrm{m}^{-2} \cdot \mathrm{dia}^{-1}\right)$ em condições adequadas de coagulação e floculação prévias. Esses dados indicam que o sistema de flotação por ar dissolvido constitui uma alternativa extremamente atraente para a remoção de 
algas e cianobatérias, tanto do ponto de vista técnico quanto econômico, requerendo pequena quantidade de ar e pequena área de implantação em virtude das taxas de aplicação superficial elevadas.

Estudos realizados por LOBATO et al. (1995), em uma estação de tratamento de água (ETA) em escala plena, confirmaram as vantagens da flotação nos casos em que se tenha água bruta com alta concentração de algas, tendo obtido eficiência de remoção de algas da ordem de $92 \%$, mesmo considerando que a ETA estudada possuía um sistema de tratamento formado por coagulação, flotação por ar dissolvido e filtração, ou seja, sem a etapa de floculação antes da flotação.

VLASKI et al. (1997) realizaram ensaios comparativos entre a sedimentação e a flotação por ar dissolvido para a remoção de cianobactérias do gênero Microcystis aeruginosa presentes em água proveniente de um reservatório. Foi observado que a dosagem de coagulante necessária para a remoção satisfatória desses organismos pela técnica de flotação foi de duas a três vezes menor ( 7 a $12 \mathrm{~g}$ de $\mathrm{Fe}^{3} \cdot \mathrm{m}^{-3}$ ) que a dosagem necessária para a sedimentação $\left(20\right.$ a $\left.24 \mathrm{~g} \mathrm{Fe} \cdot \mathrm{m}^{-3}\right)$.

REALI e SANTOS (1999) operaram uma unidade piloto de flotação por alta taxa, tratando água destinada ao abastecimento com elevada concentração de algas em suspensão. Foi investigada a influência da taxa de aplicação superficial aparente na flotação. Esses pesquisadores observaram que o sistema apresentou, para a taxa de aplicação superficial aparente de $220 \mathrm{~m}^{3} \cdot \mathrm{m}^{-2} \cdot \mathrm{dia}^{-1}$, remoção de clorofila - a de 98,2\%, remoção de turbidez de $86,0 \%$ e remoção de sólidos suspensos de 93,6\%. Assim, esse sistema de flotação apresenta-se como alternativa bastante atraente para o tratamento de águas com elevadas concentrações de algas, devido à sua alta eficiência e por requerer baixas quantidades de ar dissolvido. 
DOMBROSKI (1996) cita, entre várias vantagens do sistema de flotação por ar dissovido, a possibilidade de remoção de matéria orgânica volátil, sabor e odor devido ao mecanismo de "stripping" que ocorre no processo de flotação.

TEIXEIRA e ROSA (2006), realizaram trabalho de pesquisa em duas partes distintas: A parte I, destinada ao estudo comparativo da sedimentação e da flotação por ar dissolvido para a remoção de células de Microcystis aeruginosa, avaliando os efeitos das condições operacionais de cada fluxograma de tratamento e, a parte II, baseada no mesmo estudo comparativo, porém avaliando a influência da matéria orgânica presente na água bruta a ser tratada.

Na parte I, foram empregados dois coagulantes distintos, o sulfato de alumínio convencional e o sulfato de alumínio pré-polimerizado com elevada basicidade, sendo que este último levou a melhores resultados em ambos os fluxogramas de tratamento. Entretanto, a flotação por ar dissolvido, comparativamente, apresentou melhores resultados que a sedimentação, com maior eficiência em termos de remoção de clorofila - a (93 a 98\%) e menor dosagem de coagulante $\left(3,0 \mathrm{mg} \cdot \mathrm{L}^{-1}\right.$ versus $5,0 \mathrm{mg} \cdot \mathrm{L}^{-1}$ de sulfato de alumínio pré-polimerizado com elevada basicidade). O melhor desempenho da flotação também foi caracterizado pela menor energia de mistura na coagulação $\left(380 \mathrm{~s}^{-1}\right.$ versus $\left.743 \mathrm{~s}^{-1}\right)$ e floculação mais rápida porém mais enérgica ( 8 min e $70 \mathrm{~s}^{-1}$ versus $15 \mathrm{~min}$ e $24 \mathrm{~s}^{-1}$ ). Na melhor condição de flotação foram observados flocos menores e mais coesos, bem como a mínima taxa de recirculação estudada (8\%).

Na parte II, ambos os fluxogramas de tratamento tiveram melhor desempenho quando tratando a água bruta com menor concentração de matéria orgânica. Novamente, a flotação por ar dissolvido comparativamente apresentou melhor 
desempenho que a sedimentação em termos de remoção de clorofila - a (maior que $92 \%)$, com emprego de menor dosagem de coagulante $\left(8,0 \mathrm{mg} \cdot \mathrm{L}^{-1}\right.$ versus $12 \mathrm{mg} \cdot \mathrm{L}^{-1}$ de sulfato de alumínio). Também foi observado que o desempenho da sedimentação foi mais influenciado pela presença de matéria orgânica na água bruta, fato justificado pela maior dificuldade da formação de flocos densos.

Finalmente, observa-se que em ambas as partes desse estudo não foi verificada significativa remoção de microcistina extracelular, entretanto, também não foi verificada significativa lise celular e conseqüente liberação de microcistina para o meio líquido.

TEIXEIRA e ROSA (2006), em outro estudo, avaliaram o desempenho da flotação por ar dissolvido associada a nanofiltração para a remoção de células de Microcystis aeruginosa e de microcistina. A membrana empregada para a nanofiltração era um composto de amido de polipiperazina junto a uma membrana microporosa de polisulfona apoiada em um suporte de poliéster. Esse conjunto apresentava permeabilidade hidráulica de $5,9 \mathrm{~kg} \cdot \mathrm{h}^{-1} \cdot \mathrm{m}^{-2} \cdot \mathrm{bar}^{-1}$ a $25^{\circ} \mathrm{C}$ e porosidade de $0,43 \mathrm{~nm}$. O potencial zeta da superfície dessa membrana era ligeiramente positivo a um $\mathrm{pH}$ de 4,0 , atingia a neutralidade a um $\mathrm{pH}$ de 4,2 e passava a carga negativa para valores de $\mathrm{pH}$ superiores (até 8,3 que foi o maior valor estudado). Na presença de cátions de cálcio, o ponto isoelétrico foi elevado do $\mathrm{pH} 4,2$ para valores de 5 a 6 e a membrana e a carga ficou ligeiramente negativa em toda a faixa de $\mathrm{pH}$ estudada.

Para a flotação por ar dissolvido foram avaliadas duas alternativas de saturação da água de recirculação, a pressurização convencional com ar e o emprego de uma mistura de ar e gás carbônico. Os resultados indicaram melhor desempenho da flotação com a pressurização convencional com ar e também foi observado que no 
caso do emprego da mistura de ar e gás carbônico houve uma sensível lise celular com liberação de microcistina para o meio líquido. A maior solubilidade do gás cabônico na água resultou em maior formação de bolhas quando da introdução da mistura saturada na câmara de flotação e, consequentemente, maior energia de mistura conferida ao meio líquido devido à liberação e flotação das microbolhas, resultando em piores condições de adesão das bolhas aos flocos e maior estresse celular com consequente liberação de microcistina intracelular.

Mesmo na pior condição da mistura de ar e gás carbônico, exelente desempenho em termos de remoção das células de Microcystis aeruginosa e de microcistina extracelular foi observado com a associação da flotação por ar dissolvido e a nanofiltração. Foi garantido 100 \% de remoção celular e das toxinas associadas, além de excelente controle da turbidez e remoção de outros micropoluentes.

\subsection{3 - O Emprego da Oxidação Química}

Oxidação é o nome dado ao processo em que há aumento do estado de oxidação de uma substância. Na reação de oxidação, que ocorre simultaneamente com a de redução, as substâncias orgânicas doam elétrons, ganham oxigênio e perdem hidrogênio. De modo geral, no tratamento de água, a oxidação tem como objetivo converter substâncias indesejáveis em substâncias não prejudiciais ou não objetáveis.

Os oxidantes mais usados no tratamento de água são o cloro, os hipocloritos, o dióxido de cloro, o permanganato de potássio, o oxigênio e o ozônio. Geralmente o grau de degradação de um composto orgânico por um oxidante, segundo ANSELME et al (1992), depende de muitos fatores, incluindo a força do oxidante, o modo como o oxidante ataca as ligações do composto, a estrutura dos compostos e os fatores 
do meio como pH, temperatura, concentração de substâncias químicas e a presença de substâncias que interferem na reação de oxidação.

A seguir, são descritas algumas das características dos oxidantes empregados nos ensaios em questão:

- Hipocloritos: Segundo a Water Environment Federation (1996), os hipocloritos são sais de ácido hipocloroso com característica de fortes oxidantes. O hipoclorito de sódio tem aparência amarelada, é altamente alcalino e corrosivo, tem forte odor de cloro. É altamente instável com degradação acelarada por calor, luz e longo tempo de estocagem. É destrutivo para a madeira, corrosivo para a maioria dos metais e é nocivo para pele, olhos e outros tecidos do corpo.

- Permanganato de potássio: Segundo a EPA (1999), o permanganato de potássio é usado, preferecialmente, para a remoção de cor, odor, controle de crescimento biológico e remoção de ferro e manganês. Tendo em vista não formar compostos organoclorados quando aplicado em águas contendo matéria orgânica, o permanganato também tem a função de controlar a formação dos trihalometanos, pois no caso de sua associação com o cloro o permanganato é aplicado como pré-oxidante no início do sistema de tratamento, reservando o cloro somente para a pós oxidação e desinfecção, quando a água está com menor concentração de matéria orgânica. Devido a suas características, dependendo de sua dosagem o permanganato de potássio pode conferir elevada cor e residual de manganês à água tratada, fatores que podem comprometer a potabilidade da mesma. Esse aspecto limita os pontos de aplicação do permanganato de potássio, que nunca pode ser feito a jusante da filtração, sendo mais aconselhado a aplicação a montante da sedimentação ou flotação para melhorar as condições de remoção de cor e residual de manganês. Assim como o cloro, o permanganato de potássio é nocivo para pele, olhos e outros tecidos do corpo.

Segundo DANIEL (2001), CHORUS \& BARTRAM (1999), os oxidantes são empregados nos sistemas de tratamento de água com diversos objetivos: controlar o gosto, odor, manter os filtros limpos, remover o ferro e o manganês, destruir o sulfeto de hidrogênio, diminuir a cor, controlar o crescimento bacteriano, aprimorar a 
coagulação e controlar algas no pré-tratamento. Nos sistemas de distribuição de água, são empregados como agentes desinfetantes tendo em vista seu efeito residual, bem como para a limpeza das tubulações e reservatórios.

MA \& LIU (2001) estudaram o efeito do cloro, ozônio e dióxido de cloro em águas contendo culturas de Scenedesmus sp. A atividade algal e a concentração de clorofila diminuíram e a concentração de substâncias orgânicas dissolvidas aumentou com maiores concentrações dos oxidantes. $\mathrm{O}$ coagulante utilizado foi $\mathrm{O}$ sulfato de alumínio e o pré-tratamento com dióxido de cloro (dosagens de 1,0 ; 3,0 e $\left.5,0 \mathrm{mg} \cdot \mathrm{L}^{-1}\right)$ melhorou o efeito da coagulação, enquanto a pré-oxidação com cloro (dosagens de 10,0 e 20,0 mg. $\mathrm{L}^{-1}$ ) aumentou a dosagem requerida de coagulante em $15 \%$.

A pré-oxidação foi estudada em escala piloto por LAGE FILHO \& FERREIRA (1997) em tratamento de águas eutrofizadas. Esses autores concluíram que, por promover a formação de flocos mais resistentes, a pré-oxidação com cloro livre atuou como um auxiliar de coagulação, proporcionando melhor remoção de cor aparente e melhor remoção de carbono orgânico total e substâncias húmicas oriundas de matéria orgânica decomposta.

HART et al (1997), indicam que a oxidação com o emprego de permanganato de potássio e ozônio é bastante efetiva na redução da concentração de microcistina e anatoxina dissolvidas no meio líquido, enquanto que a aplicação de cloro é efetiva apenas para a remoção da microcistina.

TSUJI et al (1997) observaram que a oxidação de microcistina com hipoclorito de sódio foi bastante efetiva para uma dosagem de $2,8 \mathrm{mg}^{-\mathrm{L}^{-1}}$ de cloro livre, quando foi observada eficiência de remoção de microcistina extracelular de cerca de 99 \% para 
um tempo de contato de 30 minutos. Entretanto, assim como observado por outros pesquisadores, a aplicação do hipoclorito de sódio na água bruta causou lise celular e conseqüente liberação de microcistina para o meio líquido, bem como formação de trihalometanos.

Com o objetivo de estudar a formação e o controle de trihalometanos decorrente da oxidação química com cloro, OLIVEIRA (2002) realizou ensaios em escala de bancada simulando as condições operacionais da ETA Alto da Boa Vista existente na Região Metropolitana de São Paulo. Como estratégias de redução da formação dos trihalometanos foram estudadas duas condições experimentais: a mudança do ponto de aplicação do cloro para após a clarificação, sendo considerada condição de coagulação intensificada (enhanced coagulation) para aumentar a remoção dos precursores de THM; o emprego do permanganato de potássio como oxidante alternativo e o controle do pH de coagulação.

Os ensaios realizados por OLIVEIRA (2002) permitiram concluir que o ponto de aplicação do cloro influi na formação dos THM, sendo que esta é diretamente proporcional à dosagem de cloro e é mais pronunciada quando o cloro é utilizado na pré-cloração. Também foi observado que o emprego do permanganato de potássio em substituição ao cloro na pré-oxidação, resultou em menor formação de THM, embora essa redução não tenha sido muito significativa. O controle do processo de coagulação intensificada, a um pH ótimo na faixa de 5,5 a 6,5 , visando aumentar a remoção de matéria orgânica, foi muito efetivo na minimização da formação de THM na água final.

DINIZ (2005) estudou o controle da formação de THM nas Estações de Tratamento de Água Alto Tietê e Casa Grande existentes na Região Metropolitana de São 
Paulo, correlacionando a formação de THM com as demandas de cloro e quantidade de matéria orgânica presente na água bruta durante o período de 1997 a 2004 . Foi observado que a formação de THM variou sazonalmente, nos períodos de chuva e de temperatura mais elevada e a maior demanda de cloro resultou em aumento das concentrações de THM. A partir de 2004, houve uma redução de aproximadamente 55 \% na concentração de THM devido à substituição do cloro, como agente préoxidante, pelo permanganato de potássio, bem como devido à melhoria do processo de coagulação.

NICHOLSON et al (1994) estudaram a oxidação de hepatotoxinas com a aplicação de cloro e cloraminas, bem como a toxicidade dos subprodutos formados através de bioensaios com camundongos. Foi observado que a aplicação de cloro livre foi muito mais efetiva que a aplicação de cloraminas, sendo que para dosagem de cloro livre igual a $10 \mathrm{mg} \cdot \mathrm{L}^{-1}$ (0,5 mg. $\mathrm{L}^{-1}$ de cloro residual após tempo de contato de 30 minutos) foi verificada uma eficiência de remoção de nodularina de $95 \%$, entretanto, para todos os oxidantes avaliados (cloro gás, hipoclorito de cálcio e hipoclorito de sódio) a oxidação foi extremamente dependente do $\mathrm{pH}$, sendo que para valores de $\mathrm{pH}$ superiores a 8,0 a queda de eficiência foi significativa. Isso pôde ser justificado pelo decréscimo da concentração do ácido hipocloroso com o aumento do pH (79\% no $\mathrm{pH} 7,0,55 \%$ no $\mathrm{pH} 7,5,28 \%$ no pH 8,0 e $0,4 \%$ no pH 10,0 , todos a $20{ }^{\circ} \mathrm{C}$ ), sendo que este ácido tem maior poder de oxidação que o íon hipoclorito.

No caso das cloraminas, para dosagens de cerca de $20 \mathrm{mg}^{\mathrm{L}} \mathrm{L}^{-1}$ de monocloramina, a remoção de hepatoxinas foi de apenas $10 \%$ após 30 minutos de tempo de contato e cerca de $20 \%$ após 5 dias. Em termos de subprodutos formados pela reação de oxidação das hepatotoxinas, os bioensaios com camundongos não detectaram toxicidade. 
HO et al (2006) estudaram a oxidação com cloro de quatro microcistinas distintas, sendo que a oxidação dessas substâncias foi dependente do tempo de contato e de cada toxina de forma distinta. Uma escala de facilidade de oxidação pôde ser defina: microcistina $\mathrm{YR}>$ microcistina $\mathrm{RR}>$ microcistina $\mathrm{LR} \geq$ microcistina $\mathrm{LA}$. Partindo de uma concentração inicial de microcistina na água igual a 5,0 $\mu \mathrm{g} \cdot \mathrm{L}^{-1}$, dosagem de cloro livre de $1,5 \mathrm{mg} \cdot \mathrm{L}^{-1}$ e tempo de contato de 30 minutos foram suficientes para a remoção de 90 \% de todas as microcistinas avaliadas. Embora a cloração tenha sido efetiva para todas as microcistinas nas condições de ensaio avaliadas, esse estudo mostra a importância do conhecimento específico da microcistina a ser removida, devido às diferentes resistências de oxidação de cada substância.

ACERO et al (2005), estudando a oxidação de três tipos de microcistina (LR, RR e YR) com a aplicação de cloro em uma ampla faixa de $\mathrm{pH}(4,8$ a 8,8), observaram uma reação de oxidação de segunda ordem, sendo que as taxas de degradação dos três tipos de microcistina sofreram, de forma análoga, queda significativa com a elevação do pH, confirmando que a oxidação da microcistina com cloro é viável desde que o pH seja mantido abaixo de 8,0.

CHEN et al (2005) realizaram experimento semelhante ao descrito anteriormente, porém considerando a cinética da oxidação com o permanganto de potássio na remoção da microcistina $\mathrm{RR}$. Foi observado que a efetividade da oxidação é mais influenciada pelo aumento da dosagem do permanganato de potássio e temperatura do que pela variação do $\mathrm{pH}$. A influência do $\mathrm{pH}$, embora ocorra de forma análoga à oxidação com cloro, é menos significativa. Foi constatada a efetividade da remoção de microcistina com o emprego do permanganato de potássio, com a concentração inicial de microcistina RR superior a $4300 \mu \mathrm{g} \cdot \mathrm{L}^{-1}$ e remoção acima de 99,9 \% para uma dosagem de $5,0 \mathrm{mg} \cdot \mathrm{L}^{-1}$ e tempo de contato superior a 10 minutos. Para 
dosagem de $10 \mathrm{mg} \cdot \mathrm{L}^{-1}$, a mesma eficiência pôde ser observada para tempo de contato da ordem de 5 minutos.

Comparando-se os dois estudos citados anteriormente, observa-se que 0 permanganato de potássio parece ser um oxidante mais enérgico que o cloro para a remoção da microcistina e menos dependente da variação de pH. Entretanto, as dosagens de permanganato aplicadas no estudo desenvolvido por CHEN et al (2005), são muito elevadas e atípicas de ocorrência em sistemas de tratamento de água em virtude do risco de degradação da qualidade final da água tratada, devido ao aumento da cor e residual de manganês total.

No estudo desenvolvido por CHEN et al (2005), para tempos de contato variando na faixa de 5 a 10 minutos e dosagens permanganto na faixa de 5 a $10 \mathrm{mg} \cdot \mathrm{L}^{-1}$, foi possível a redução da concentração inicial de microcistina de cerca de $4300 \mu \mathrm{g} \cdot \mathrm{L}^{-1}$ para níveis inferiores a $1,0 \mu \mathrm{g} \cdot \mathrm{L}^{-1}$, atendendo ao padrão de potabilidade definido pela OMS e pela portaria 518. Entretanto, seria importante avaliar o desempenho do permanganato de potássio segundo dosagens mais modestas e viáveis de aplicação em ETA, bem como considerar águas brutas mais próximas da realidade em termos de concentração de microcistina.

\subsection{4 - O Emprego da Adsorção com Carvão Ativado}

É senso comum entre diversos pesquisadores (FALCONER et al ,1989; JONES et al, 1993) que o emprego da adsorção com carvão ativado é uma das técnicas que tem apresentado os resultados mais promissores para a remoção das cianotoxinas, tanto em experiências realizadas em escala de bancada como aplicações práticas em estações de tratamento de pequeno, médio e grande porte. 
As técnicas de adsorção estudadas em laboratório e aplicadas em escala real consistem, basicamente, na aplicação do carvão ativado em pó ou na utilização de carvão ativado granular em leitos fixos de adsorção.

Visando o estudo da remoção de subprodutos metabólicos de microrganismos causadores de gosto e odor em água de abastecimento, FERREIRA FILHO (2001) estudou a aplicação de carvão ativo em pó (CAP) no Sistema Produtor do Guarapiranga na Região Metropolitana de São Paulo, considerando o desempenho das instalações de aplicação de CAP existentes e simulações em escala de laboratório.

Foi constatado por esse pesquisador que a remoção de MIB (2-methylisoborneol) e Geosmina (trans-1, 10 dimethyl-trans-9-decalol) foi fortemente influenciada pela origem do carvão ativado, sendo que os melhores resultados foram obtidos com carvões de origem vegetal. O MIB foi o composto de mais difícil remoção da fase líquida, sendo que concentrações da ordem de $400 \mathrm{ng} \cdot \mathrm{L}^{-1}$ foram reduzidas para concentrações remanescentes da ordem de 25 a $50 \mathrm{ng} \cdot \mathrm{L}^{-1}$ para dosagem de CAP igual a $40 \mathrm{mg} \cdot \mathrm{L}^{-1}$. Adicionalmente, foi observado que a aplicação de cloro ou permanganato de potássio, visando a pré-oxidação química, foi prejudicial ao desempenho da adsorção com CAP na remoção de MIB.

JONES et al (1993) constataram que ambas as técnicas de adsorção são efetivas na remoção das cianotoxinas, no entanto, a aplicação do carvão ativado granular tem se mostrado mais promissora na remoção dessas toxinas em comparação com a aplicação do carvão ativado em pó, pois este último leva a vários inconvenientes de ordem econômica e operacional devido às elevadas dosagens necessárias para efetivamente remover as cianotoxinas. A experiência da AWWA (1995) confirma a 
baixa efetividade da aplicação do carvão ativado em pó quando em baixas dosagens.

Adicionalmente, JONES et al (1993) constataram que a utilização de colunas de carvão ativado granular, principalmente quando instaladas a jusante das unidades de filtração para evitar a interferência negativa do coagulante e flocos formados na etapa de floculação, apresentaram elevada eficiência de remoção das toxinas com tempos de detenção relativamente baixos (da ordem de 8 a 12 minutos). FALCONER et al (1989) confirmam o bom desempenho do carvão ativado granular, pois resultados obtidos em escala de laboratório indicam que unidades em escala real podem ser efetivas na remoção de cianotoxinas com tempos de detenção hidráulica da ordem de 10 a 15 minutos e autonomia operacional no intervalo de 90 a 250 dias antes da saturação da coluna de adsorção.

De acordo com Cook e Newcombe ${ }^{2}$ apud $\mathrm{HO}$ et al (2006), algumas microcistinas não são facilmente adsorvidas por carvão ativado em pó, esses autores observaram que o CAP foi efetivo na remoção das microcistinas RR e YR. Entretanto, para a microcistina LR as dosagens requeridas foram muito elevadas, inviabilizando economicamente a adsorção, e para a microcistina LA foi observado que a adsorção não apresenta bons resultados mesmo para dosagens elevadas.

\section{5 - Considerações sobre a Revisão de Literatura}

Tendo em vista o levantamento bibliográfico apresentado nos itens anteriores, observa-se que as cianobatérias apresentam características morfológicas e

\footnotetext{
${ }^{2}$ COOK, D. , NEWCOMBE, G. (2002). Removal of Mirocystin with Powdered Activated Carbon. Water Science Technology. : Water Supply 2 (5/6), 201-207.
} 
fisológicas que as tornam excelentes competidoras ambientais e, em decorrência dessa habilidade, apresentam grande potencial de prevalência nos ambientas aquáticos com elevado potencial de eutrofização.

Como consequência, os manancias lacustres explorados para fins de abastecimento de água potável freqüentemente apresentam riscos à saúde pública, quando os eventos de eutrofização são caracterizados pela predominância de cianobatérias potencialmente tóxicas.

Nos ambientes aquáticos, parte das cianotoxinas encontra-se confinada no interior das células, sendo liberadas em quantidades substanciais predominantemente após a lise celular. Esse fato demonstra a importância da adoção de processos eficientes de remoção de células íntegras de cianobactérias nos sistemas de tratamento de água. É consenso entre vários pesquisadores o melhor desempenho do fluxograma de tratamento, baseado nas etapas de coagulação, floculação, flotação por ar dissolvido e filtração, em comparação ao fluxograma convencional, baseado nas etapas de coagulação, floculação, sedimentação e filtração. Portanto, a técnica de flotação por ar dissolvido (FAD) constitui alternativa bastante atraente quando se pretende a remoção de algas e cianobactérias em sistemas de tratamento de águas para abastecimento.

No que concerne à remoção da parcela de cianotoxinas liberadas para o meio aquático (toxinas extracelulares), a experiência acumulada até o presente, apesar de não muito extensa, demonstra que os processos de oxidação química com o emprego de vários oxidantes (cloro, permanganato de potássio, ozônio etc) e de adsorção em carvão ativado, podem constituir alternativas eficazes para tal 
finalidade, dependendo do modo e das condições em que são aplicadas considerando o conjunto de unidades de um sistema de tratamento de água.

Em vista desse panorama, torna-se oportuna a investigação e comparação de alternativas apropriadas para o tratamento de águas para abastecimento provenientes de mananciais com grande potencial de eutrofização. Alternativas estas, que possibilitem a definição de estratégias seguras e econômicas baseadas na associação de vários processos unitários, de maneira a serem criadas "barreiras múltiplas", destinadas à remoção de células íntegras de cianobactérias e, conseqüentementede, da parcela de cianotoxinas contida nas mesmas (intracelulares), bem como à remoção complementar das cianotoxinas livres no meio líquido (extracelulares).

\section{6 - Resultados dos Estudos Anteriores Realizados no Laboratório de Tratamento Avançado e Reuso de Águas - EESC/USP}

\subsection{1 - Generalidades}

Conforme citado anteriormente no capítulo 1, desde meados do ano de 2003 até 2007, sob a orientação do Prof. Dr. Marco Antônio Penalva Reali, uma equipe formada por um aluno de iniciação científica, quatro mestrandos e este doutorando, realizou vários trabalhos de pesquisa envolvendo o estudo do emprego de técnicas convencionais de tratamento de água associadas à adsorção em carvão ativado e oxidação química para a remoção de cianobactérias e a microcistina.

A água de estudo empregada nos ensaios teve como base a água coletada no reservatório de Barra Bonita, conforme descrito com detalhes nos itens 4.1 e 4.2. 
Deve-se salientar que o autor do projeto de doutorado em questão teve participação destacada na equipe, desde o início dos trabalhos, tendo contribuído em todos os trabalhos de mestrado e de iniciação científica já concluídos. Os resultados desses trabalhos são apresentados e comentados a seguir.

3.6.2 - Dissertação de Mestrado intitulada - "Remoção de Biomassa Algal e Avaliação do Método Elisa para Determinação da Concentração de Microcistina em Ensaios de Coagulação, Sedimentação e Adsorção Realizados com Água Proveniente de Reservatório Eutrofizado“

Os primeiros resultados do grupo de pesquisa forneceram subsídios para a dissertação de mestrado defendida pela aluna Luciana Pallone Hespanholo Ferreira (FERREIRA, 2005), junto ao programa de pós-graduação do Departamento de Hidráulica e Saneamento da Escola de Engenharia de São Carlos - USP.

Nessa primeira etapa foi avaliada a remoção de microcistina em processo convencional de tratamento de água (coagulação, floculação, sedimentação e filtração) associado à adsorção por carvão ativado em pó, em ensaios em escala de bancada.

Nos ensaios realizados por FERREIRA (2005), observou-se que a coagulação e floculação da água de estudo somente foi bem sucedida com o emprego de cloreto férrico segundo dosagens bastante elevadas, acima de $80 \mathrm{mg} \cdot \mathrm{L}^{-1} . \mathrm{O} \mathrm{pH}$ de coagulação mais adequado ficou em torno de 6,0 , sendo que para esse valor não foi necessária a aplicação de alcalinizante. Somente para pequenas velocidades de sedimentação, 0,5 e 1,0 cm.min ${ }^{-1}$, que correspondem, respectivamente, a taxas de aplicação superficial em decantadores da ordem de 7,0 e 15,0 $\mathrm{m}^{3} \cdot \mathrm{m}^{-2} \cdot \mathrm{dia}^{-1}$, é que foram obtidas eficiências de remoção de cor e turbidez superiores a 80 \% para as 
maiores dosagens de cloreto férrico. A água de estudo, portanto, apresentou grande dificuldade para a coagulação, floculação e sedimentação dos flocos formados, que pode ser em parte justificada pelos elevados valores de cor e turbidez da mesma.

Em termos de material particulado em suspensão, sólidos em suspensão total e volátil, observou-se que para os ensaios sem a adição de CAP a eficiência de remoção ficou em torno de $70 \%$ considerando a água filtrada, que pode ser considerada uma eficiência baixa para o padrão do tratamento convencional de ciclo completo (coagulação, floculação, sedimentação e filtração). No entanto, para os ensaios com a adição de CAP logo após a mistura rápida, a eficiência de remoção superou o patamar de $95 \%$, sendo que essa diferença de desempenho entre os ensaios sem e com a aplicação de CAP, pode ser justificada pela contribuição da adição de carvão ativado em pó na formação de flocos com melhores características de sedimentabilidade e filtrabilidade.

Com relação à DQO, observa-se que a eficiência de remoção para ambos os ensaios, sem CAP e com CAP, ficou restrita à faixa de $70 \%$. Já com relação às formas de nitrogênio orgânico e amoniacal, representadas pelo parâmetro NTK, a eficiência verificada no ensaio com CAP foi pouco superior (60 \%) quando comparado com o desempenho verificado no ensaio sem CAP, que apresentou remoção de $40 \%$. Essa diferença de desempenho apresenta indícios do benefício, ainda que pouco expressivo, do carvão ativado na adsorção dos compostos orgânicos e amoniacais.

Quanto à microcistina, observou-se que o tratamento convencional de ciclo completo não foi efetivo para a sua remoção, que ficou restrita a uma eficiência de cerca de 15\%. Já no caso do tratamento de ciclo completo associado à adsorção através da 
aplicação de carvão ativado em pó no estágio inicial de mistura rápida, a eficiência de remoção de microcistina alcançou $93 \%$, com uma concentração final de 0,86 $\mu g \cdot L^{-1}$ que está abaixo do limite máximo definido pelo padrão de potabilidade estabelecido na portaria 518 de 25/03/2004.

O bom desempenho da condição de ensaio que considera a aplicação de CAP confirma a observação de diversos pesquisadores (FALCONER et al ,1989; JONES et al, 1993 e AWWA, 1995). No entanto, para se atingir desempenho suficiente para o enquadramento da água tratada dentro do padrão de potabilidade relativo à microcistina, foi necessária dosagem de CAP igual a $300 \mathrm{mg} \cdot \mathrm{L}^{-1}$ que pode ser considerada extremamente elevada em termos de utilização em escala real. JONES et al (1993) constataram que tanto o carvão ativado em pó quanto o granular são efetivos na remoção das cianotoxinas, no entanto, a aplicação do carvão granular tem se mostrado mais promissora na remoção dessas toxinas em comparação com a aplicação do carvão ativado em pó, pois este último leva a vários inconvenientes de ordem econômica e operacional devido às elevadas dosagens necessárias para efetivamente remover as cianotoxinas.

A experiência da AWWA (1995) confirma a baixa efetividade da aplicação do carvão ativado em pó quando em baixas dosagens. Tendo em vista o estágio de adição do CAP, ou seja, logo após a mistura rápida, a grande dosagem de CAP necessária para efetivamente remover a microcistina pode ser em parte justificada pela interferência do coagulante e dos flocos formados. Os íons de ferro provenientes do cloreto férrico empregado como coagulante podem ter competido pelos sítios de adsorção do carvão ativado, resultando na necessidade de aumento da dosagem do mesmo para garantir uma efetiva remoção da microcistina presente no meio líquido. 
A competição pelos sítios de adsorção também pode ter sido estabelecida pela presença de matéria orgânica original da água de estudo. Outro fato que pode ter contribuído para as elevadas dosagens de carvão em pó foi a baixa capacidade de adsorção do carvão utilizado, pois os ensaios de determinação da isoterma de Freundlich, resultaram em valores de $1 / \mathrm{n}$ e $\mathrm{k}_{\mathrm{ad}}$ muito baixos.

Finalmente, é importante observar que a água de estudo utilizada nesses ensaios foi caracterizada pela presença predominante de microcistina dissolvida no meio líquido e por pequena contagem de Microcystis, que resulta em pequena quantidade de toxina intracelular. Portanto, os resultados obtidos referem-se, basicamente, à toxina dissolvida no meio líquido (extracelular), indicando que o tratamento convencional não é eficaz na remoção dessas substâncias dissolvidas enquanto que a adsorção com carvão ativado atinge níveis elevados de desempenho.

3.6.3 - Dissertação de Mestrado intitulada - "Remoção de Fitoplancton e Microcistina de Águas para Abastecimento em Sistema que Associa Unidades de Adsorção por Carvão Ativado em Pó, Flotação por Ar Dissolvido e Filtração em Escala de Laboratório"

Os resultados dessa etapa de pesquisa forneceram subsídios para a dissertação de mestrado defendida pelo aluno André Luis Vieira da Silva (SILVA, 2005), junto ao programa de pós-graduação do Departamento de Hidráulica e Saneamento da Escola de Engenharia de São Carlos - USP.

Esse trabalho teve o objetivo de avaliar, em ensaios em escala de bancada, o desempenho do fluxograma de tratamento baseado na coagulação, floculação, flotação por ar dissolvido e filtração, associado à aplicação de carvão ativado em pó 
em diferentes pontos no início do fluxograma de tratamento, visando a remoção de fitoplancton e microcistina.

Em termos de coagulação, floculação e flotação da água de estudo, observa-se que o $\mathrm{pH}$ de coagulação possui grande influência no desempenho do sistema na remoção de cor e turbidez. Valores de $\mathrm{pH}$ mais baixos resultaram em um efluente de melhor qualidade e a dosagem de cloreto férrico necessária para atingir resultados satisfatórios foi da ordem de $45 \mathrm{mg} \cdot \mathrm{L}^{-1}$ para uma água de estudo com valores de cor aparente e turbidez respectivamente da ordem de 600 uH e 72 uT. Observa-se que mesmo para a condição de ensaio sem a dosagem de ácido sulfúrico para a redução do $\mathrm{pH}$, quando o $\mathrm{pH}$ de coagulação ficou em torno de 6,5 foram observados valores de cor e turbidez abaixo dos limites máximos estabelecidos na Portaria 518 de 25/03/2004.

Tendo em vista os bons resultados verificados sem a adição de ácido e considerando-se que essa prática não é padrão normal nas estações de tratamento de água existentes, os ensaios subseqüentes foram realizados sem a correção de pH quer seja pela adição de ácido ou base, sendo que o pH de coagulação sempre foi definido naturalmente em função da dosagem de coagulante (cloreto férrico). Observa-se que a água de estudo apresentava alcalinidade elevada, fator que provavelmente estabeleceu o tamponamento da água e, conseqüentemente, a estabilidade dos valores de $\mathrm{pH}$ mesmo para dosagens elevadas de cloreto férrico.

Em termos de remoção de microcistina, observa-se que apenas a aplicação do coagulante não foi suficiente para a remoção de microcistina dentro dos limites estabelecido pelo padrão de potabilidade, ou seja: menor que $1,0 \mu \mathrm{g} \cdot \mathrm{L}^{-1}$. Foram verificadas concentrações de microcistina variando de 8,0 a $9,5 \mu \mathrm{g} . \mathrm{L}^{-1}$ considerando- 
se uma água de estudo com concentração inicial de microcistina da ordem de 10 $\mu \mathrm{g} \cdot \mathrm{L}^{-1}$. As dosagens de coagulante praticadas variaram no intervalo de 35 a 50 $\mathrm{mg} \cdot \mathrm{L}^{-1}$

Nos ensaios de adsorção, observa-se que a aplicação de CAP antes da coagulação influenciou beneficamente no desempenho da coagulação, floculação e flotação da água de estudo. As dosagens maiores de CAP (30 e $40 \mathrm{mg} \cdot \mathrm{L}^{-1}$ ), resultaram em valores de cor remanescente na água submetida à flotação bem menores quando comparados à condição de aplicação de $20 \mathrm{mg} \cdot \mathrm{L}^{-1}$ de CAP. Isso indica que as partículas do carvão ativado em pó podem ter melhorado as condições de formação de flocos com benefício principalmente na remoção das substâncias coloidais responsáveis pela cor na água.

Com relação à turbidez, o que ocorreu foi o contrário, ou seja, a maior dosagem de CAP (40 mg. $\mathrm{L}^{-1}$ ) resultou em valores mais elevados de turbidez remanescente, indicando que embora a floculação tenha sido mais efetiva para a aglutinação das substâncias coloidais, parte das partículas de CAP não foram incorporadas aos flocos, aumentando a turbidez da água submetida à flotação. Entretanto, mesmo para a dosagem de $40 \mathrm{mg} \cdot \mathrm{L}^{-1}$ de CAP os valores de turbidez residual foram bem reduzidos, resultando em água submetida à flotação com turbidez menor que 1,0 UT mesmo para a dosagem mais baixa de coagulante $\left(40 \mathrm{mg} \cdot \mathrm{L}^{-1}\right)$, o que pode ser considerado um desempenho excelente para a flotação.

Com relação à remoção de microcistina com a aplicação de CAP, observa-se que as diferentes condições de ensaio resultam em diferentes desempenhos. Quanto maior foi o tempo de contato do CAP com a água de estudo antes das etapas de coagulação, floculação e flotação, maior foi a eficiência de remoção da microcistina. 
Para a condição de dosagem 5 segundos depois da mistura rápida, mesmo para a maior dosagem de CAP $\left(60 \mathrm{mg} \cdot \mathrm{L}^{-1}\right)$ o padrão de potabilidade não foi atingido, com uma concentração remanescente de microcistina da ordem de $2,0 \mu \mathrm{g} \cdot \mathrm{L}^{-1}$ na água submetida à flotação.

Para a condição de aplicação de CAP 20 segundos antes da mistura rápida, a dosagem de $60 \mathrm{mg} \cdot \mathrm{L}^{-1}$ praticamente atende o padrão de potabilidade (concentração remanescente de microcistina da ordem de $1,2 \mathrm{ug} \cdot \mathrm{L}^{-1}$ na água filtrada) e para a condição de aplicação 1,5 hora antes da mistura rápida, o que simula uma condição real de aplicação do CAP na captação da água bruta, o padrão de potabilidade é atendido (concentração remanescente de microcistina da ordem de $0,8 \mu \mathrm{g} \cdot \mathrm{L}^{-1}$ na água filtrada) para uma dosagem de CAP de $50 \mathrm{mg} \cdot \mathrm{L}^{-1}$.

Adicionalmente, foi observado que em termos de remoção de partículas sólidas representadas pela turbidez e sólidos totais e em suspensão, a aplicação de CAP piorou o desempenho do tratamento. Já com relação à absorbância que representa a matéria orgânica, a aplicação do CAP levou a uma melhora da remoção devido ao efeito de adsorção, o que era esperado.

Restringindo a análise às diferentes condições de aplicação do CAP, observa-se que a aplicação 90 minutos antes da mistura rápida levou a um melhor desempenho em termos gerais, provavelmente devido ao maior tempo de contato que foi proporcionado entre as partículas de carvão e a água de estudo. Isso se mostrou claro para a remoção de absorbância, que foi mais efetiva para o maior tempo de contato. 
Em termos de remoção de fitoplancton observa-se que o CAP aplicado antes da mistura rápida, principalmente para o maior tempo de contato (90 minutos antes da coagulação), foi verificado melhor desempenho.

Portanto, conclui-se que o maior tempo de contato do CAP com a água de estudo foi fundamental para o melhor desempenho global do fluxograma de tratamento avaliado.

3.6.4 - Dissertação de Mestrado intitulada - " Tratamento de Água para Abastecimento Contendo Cianobactérias e Microcistina em Sistema Constituído por Etapas de Pré-cloração, Coagulação, Floculação, Flotação e Adsorção em Carvão Ativado"

Os resultados dessa etapa de pesquisa forneceram subsídios para a dissertação de mestrado defendida pelo aluno Fernando Brisola de Almeida Bueno (BUENO, 2005), junto ao programa de pós-graduação do Departamento de Hidráulica e Saneamento da Escola de Engenharia de São Carlos - USP.

Esse trabalho teve o objetivo de avaliar o desempenho do fluxograma de tratamento baseado na coagulação, floculação, flotação por ar dissolvido, associado a aplicação de carvão ativado em pó e cloro em diferentes pontos no início do fluxograma de tratamento, visando a remoção de fitoplancton e da microcistina, em ensaios realizados em escala de bancada.

Em termos de coagulação, floculação e flotação da água de estudo, observa-se que a adição de oxidante (hipoclorito de sódio) antes da coagulação influiu negativamente na remoção de cor e turbidez, para uma mesma dosagem de coagulante. O hipoclorito de sódio tem caráter alcalino e para a água de estudo utilizada notou-se a tendência de melhor coagulação com menores valores de $\mathrm{pH}$. 
Para avaliar a demanda de cloro pela água de estudo, foi determinada a curva de residual de cloro, sendo que foi observado que para as dosagens mais baixas de cloro houve a formação inicial de cloro combinado e sua posterior oxidação até uma concentração mínima que define o "breakpoint", sendo que, somente após esse ponto foi observada a formação de residual de cloro livre para dosagens de oxidante superiores a $5,0 \mathrm{mg} \cdot \mathrm{L}^{-1}$.

Para avaliar a influência do oxidante em relação à microcistina foram feitos ensaios com a água de estudo aplicando-se as seguintes dosagens de oxidante $(1,0 ; 2,1 ; 6,0$ e 10,0 mg. $\mathrm{L}^{-1}$ ) e tempo de contato de 30 minutos, sem tratamento na seqüência. Para a dosagem de $1,0 \mathrm{mg} \cdot \mathrm{L}^{-1}$ de cloro houve aumento de concentração de microcistina de $28,3 \%$ sugerindo que o oxidante causou a lise ou estresse celular, o que acarretou a liberação de toxina para o meio líquido. Com a dosagem de 2,1 $\mathrm{mg} \cdot \mathrm{L}^{-1}$ a remoção de toxina foi de $85,3 \%$ e para dosagem de $6,0 \mathrm{mg} \cdot \mathrm{L}^{-1}$ de $94,1 \%$.

Esses resultados sugerem que o oxidante em dosagem suficiente oxida a toxina livre no meio líquido, causa a lise ou estresse celular e oxida parte da toxina liberada para o meio líquido. Para a água em questão, a aplicação de dosagens entre 3,0 e 4,0 mg. $\mathrm{L}^{-1}$ de hipoclorito de sódio foi capaz de promover a oxidação da maior parte da microcistina presente na água, de forma a atender o limite do padrão de potabilidade.

Com relação à formação de trialometanos decorrente da aplicação do cloro, observa-se que as concentrações dessas substâncias na água oxidada estiveram sempre abaixo do máximo permitido, que é de $0,1 \mathrm{mg} \cdot \mathrm{L}^{-1}$, para todos os tempos e dosagens investigados. 
Com relação aos ensaios que associam a pré-oxidação com cloro (hipoclorito de sódio aplicado 10 segundos antes da coagulação) e as etapas de coagulação, floculação, flotação e filtração, observa-se que a concentração de microcistina na água submetida à flotação atingiu o padrão de potabilidade (concentração da ordem de $0,8 \mu \mathrm{g} \cdot \mathrm{L}^{-1}$ ) para as dosagens de $50 \mathrm{mg} \cdot \mathrm{L}^{-1}$ e $6,1 \mathrm{mg} \cdot \mathrm{L}^{-1}$ de coagulante e oxidante, respectivamente e ficou muito próximo (concentração da ordem de $1,1 \mu \mathrm{g} \cdot \mathrm{L}^{-1}$ ) quando utilizada dosagem de $45 \mathrm{mg} \cdot \mathrm{L}^{-1}$ de coagulante e $6,0 \mathrm{mg} \cdot \mathrm{L}^{-1}$ de oxidante. A eficiência de remoção de toxina pela oxidação aumentou com a dosagem de oxidante e também com a associação com o coagulante. Ou seja, os melhores resultados de oxidação da microcistina ocorreram quando foi aplicada a maior dosagem de coagulante estudada $\left(50 \mathrm{mg} \cdot \mathrm{L}^{-1}\right)$ associada à maior dosagem de cloro investigada, ou seja, 6,0 mg. $\mathrm{L}^{-1}$. Para esse caso a remoção de toxina foi de $94,3 \%$. A água de estudo avaliada apresentava concentração de microcistina da ordem de $14,5 \mu \mathrm{g} \cdot \mathrm{L}^{-1}$.

Para a condição de aplicação do hipoclorito de sódio 90 minutos antes da coagulação, foi possível constatar que o maior tempo de contato do oxidante com a água de estudo fez piorar as condições do efluente para as duas dosagens de coagulante (45 e $50 \mathrm{mg} \cdot \mathrm{L}^{-1}$ ) e as duas dosagens de oxidante investigadas 2,1 e 6,0 mg. $\mathrm{L}^{-1}$ ), em relação aos residuais de cor aparente, turbidez, absorbância a 254 nm, DQO e microcistina.

Considerando os ensaios que associam a pré-oxidação com cloro (hipoclorito de sódio aplicado 10 segundos antes da coagulação) e a adsorção com CAP antes da coagulação, observa-se que com a adição de $20 \mathrm{mg} \cdot \mathrm{L}^{-1}$ de carvão ativado houve redução dos valores dos parâmetros avaliados em relação ao tratamento sem carvão para todas as dosagens de coagulante e oxidante estudadas. A adição de 20 
mg. $\mathrm{L}^{-1}$ de carvão resultou em aumento de eficiência de até $69,4 \%$ em relação ao desempenho sem CAP na remoção de toxina. Com relação aos THM, a adição de CAP também contribuiu para a diminuição da concentração na água oxidada. Entretanto, houve piora nos resultados de cor, turbidez, absorbância a 264 nm e DQO, que pode ter sido influenciada pela presença de resíduos de carvão.

3.6.5 - Trabalho de Iniciação Científica Intitulado - "Monitoramento da Evolução da Toxicidade de Uma Cultura de Microcystis aeruginosa e Avaliação da remoção de Microcistina por Oxidação com Hipoclorito de Sódio, Coagulação e Flotação por Ar Dissolvido"

Os resultados dessa etapa de pesquisa forneceram subsídios para o trabalho de iniciação científica desenvolvido por MIGLIATI (2006), junto ao programa de pósgraduação do Departamento de Hidráulica e Saneamento da Escola de Engenharia de São Carlos - USP.

Em termos básicos, esse trabalho desenvolvido em escala de bancada teve o objetivo de avaliar o desempenho do fluxograma de tratamento baseado na coagulação, floculação, flotação por ar dissolvido e filtração associado à pósoxidação com cloro da água filtrada, visando a remoção de microcistina.

Em termos de coagulação, floculação e flotação da água de estudo, com cor aparente igual a $660 \mathrm{uH}$ e turbidez igual a 64 uT, foram observadas boas condições de tratabilidade com uma dosagem de cloreto férrico igual a $76 \mathrm{mg} \cdot \mathrm{L}^{-1}$ e $\mathrm{pH}$ de coagulação decorrente dessa dosagem igual a 5,95. Para essas condições de tratabilidade foram obtidos valores de cor aparente e turbidez respectivamente iguais a 7,0 uH e 0,61 uT, que correspondem a eficiências de remoção de cor e turbidez de aproximadamente $99 \%$. 
A exemplo do trabalho apresentado no item 3.6.4, foi determinada uma curva de residual de cloro da água filtrada para avaliar as condições de demanda de oxidante dessa água. Nessa curva não foi observado o breakpoint, indicando que o cloro residual formado é livre desde as dosagens mais baixas de cloro ativo, tendo em vista a pouca disponibilidade de nitrogênio amoniacal para a formação de cloraminas. Outro aspecto que pode ser observado é a diferença entre as demandas de cloro verificadas na água de estudo (trabalho relativo ao item 3.5.3) e na água filtrada. Enquanto que a água de estudo apresentou uma grande demanda com residuais de cloro combinado ou livre abaixo de $1,0 \mathrm{~m} \cdot \mathrm{L}^{-1}$ para um intervalo de dosagem de cloro ativo de 1,0 a $9,0 \mathrm{mg} \cdot \mathrm{L}^{-1}$, a água filtrada apresentou demandas significativamente menores, com residuais de cloro livre de até $8,0 \mathrm{mg} \cdot \mathrm{L}^{-1}$ para uma faixa de dosagem de 1,0 a $10,0 \mathrm{mg} \cdot \mathrm{L}^{-1}$ de cloro ativo.

Portanto, os resultados encontrados nas duas águas são coerentes tendo em vista suas características qualitativas, principalmente com relação à presença de nitrogênio amoniacal e, conseqüentemente, o potencial de formação de cloro combinado, bem como a presença de matéria orgânica que incide na demanda de cloro livre e combinado.

Nos ensaios relativos à investigação da pós-oxidação com cloro na remoção da microcistina, foi observado que a partir da dosagem de $3,0 \mathrm{mg} \cdot \mathrm{L}^{-1}$ de cloro ativo na água filtrada, o padrão de potabilidade com relação à microcistina foi atendido (valores menores que 1,0 $\mathrm{Mg}^{-\mathrm{L}^{-1}}$ ) para qualquer um dos tempos de contato de oxidação avaliados (15; 30 e 60 minutos). Isso caracteriza uma eficiência de remoção de microcistina superior a 94\% tendo como base a concentração inicial de $15 \mu \mathrm{g} \cdot \mathrm{L}^{-1}$ na água de estudo. Também foi observada uma leve tendência de aumento de eficiência relacionada com o aumento do tempo de contato para a oxidação. 
Com relação aos residuais de cloro, observa-se que os valores encontrados estão coerentes com a curva de residual e também são influenciados, de maneira mais significativa, pelo tempo de contato de oxidação. Coerentemente, com o aumento do tempo de contato ocorreu maior consumo de cloro, resultando em menores concentrações residuais. 


\section{4 - MATERIAIS E MÉTODOS}

\section{1 - Considerações Iniciais}

Os ensaios de tratabilidade e as análises físico-químicas e biológicas foram realizados no Laboratório de Tratamento Avançado e Reuso de Águas - LATAR (ensaios, determinações físico-químicas e de concentração de microcistina) e no Laboratório de Biotoxicologia de Águas Continentais e Efluentes - BIOTACE (contagem e identificação de fitoplâncton), ambos do Departamento de Hidráulica e Saneamento da Escola de Engenharia de São Carlos - USP.

Os trabalhos iniciais do grupo de pesquisa, desenvolvidos no LATAR, apresentaram resultados promissores, mas também foram caracterizados por dificuldades operacionais, principalmente o primeiro trabalho relativo à dissertação de mestrado defendida pela aluna Luciana Pallone Hespanholo Ferreira. O desenvolvimento desse trabalho conferiu à equipe de pesquisa a experiência necessária para a reavaliação dos métodos definidos inicialmente, de forma a otimizar os procedimentos laboratoriais, aprimorar os ensaios e resultados obtidos e, principalmente, investigar condições experimentais não previstas inicialmente, mas que se mostraram promissoras tendo em vista os primeiros resultados obtidos.

Com relação ao preparo da água de estudo, que é descrito detalhadamente no item 4.2, embora o reservatório de Barra Bonita tenha sido adotado como manancial a ser explorado tendo em vista a estabilidade físico -química de suas águas e o seu estado eutrófico com predominância de Microcystis, foi encontrada grande dificuldade para a coleta de água apropriada para desenvolvimento dos ensaios, pois era necessária a presença de elevada concentração de algas, cianobactérias, 
principalmente de Microcystis $s p$. e da toxina microcistina na forma extracelular (toxina dissolvida no meio líquido) e intracelular (toxina presente na célula). FERREIRA (2005) desenvolveu seu estudo durante o período de chuvas e, conseqüentemente, a extratificação vertical do reservatório de Barra Bonita foi pouco freqüente devido aos eventos de chuvas intensas, mudanças climáticas bruscas e ventos que favoreceram a mistura das águas.

Conforme citado anteriormente no item 3.3, a Microcystis apresenta vacúolos de gás que a faz flutuar e se estabelecer na profundidade mais conveniente na coluna de água, possuindo, portanto, um relevante mecanismo de competição sobre as demais algas e cianobactérias. No entanto, durante o período de estudo esse mecanismo tornou-se ineficaz e o florescimento de Microcystis não ocorreu com a freqüência e intensidade necessárias para o preparo da água de estudo.

Para compensar a deficiência da água de estudo em termos da presença de microcistina, foi adicionada à mesma um extrato concentrado dessa toxina. Essa prática foi fundamental para viabilizar os ensaios desenvolvidos, sendo que o extrato foi preparado a partir da coleta de amostras da "nata concentrada" de algas existente na superfície do reservatório de Barra Bonita e posterior aplicação de ultrasom à essas amostras, para provocar a lise celular e conseqüente liberação de toxina.

Entretanto, embora eficaz na elevação da concentração de toxina da água de estudo, que passou a apresentar cerca de $12 \mu \mathrm{g} \cdot \mathrm{L}^{-1}$ de microcistina, o extrato elevou demasiadamente a cor da água de estudo, alterando suas características físicoquímicas naturais e dificultando sua coagulação e floculação. Adicionalmente, foi observado que a água de estudo apresentou predominantemente a forma dissolvida 
de microcistina, pois a pequena quantidade de algas Microcystis fez com que a parcela de microcistina intracelular fosse irrelevante. Essa característica da água tornou os ensaios desse primeiro trabalho restritos apenas à análise de remoção da microcistina em solução, pois não foi possível verificar a eficiência dos processos de tratamento estudados na remoção das células íntegras e, portanto, da porção de toxina contida no interior das mesmas.

Tendo em vista os inconvenientes da adição do extrato de microcistina preparado a partir da coleta de amostras concentradas de cianobatérias e a aplicação de ultrasom, foi desenvolvida a preparação do extrato de Microcystis e de microcistina a partir de cultura de linhagem tóxica, sendo que a água de estudo passou a ser preparada através da mistura dessa cultura à água coletada em Barra Bonita, de maneira a elevar a concentração de células de cianobatérias, bem como de microcistina livre no meio líquido.

Com relação à determinação da concentração de microcistina, observa-se que a técnica adotada no estudo inicial foi adequada tendo em vista a precisão, a rapidez das determinações e a necessidade de pequeno volume de amostras, o que viabilizou a realização dos ensaios em escala de bancada. Dessa forma, foi mantido o emprego do método de Imunoadsorção Ligado a Enzima (ELISA) com a utilização de kit de placas da Sovereing Brasil e a leitura das placas feita através de espectrofotometria em comprimento de onda de $450 \mathrm{~nm}$, conforme é apresentado com mais detalhes posteriormente.

Tendo em vista a experiência adquirida com a realização do primeiro trabalho de pesquisa, os demais trabalhos tiveram sua metodologia otimizada de maneira a contornar os problemas inicialmente vivenciados. 


\section{2 - A Água de Estudo}

\subsection{1 - Preparo e Conservação}

A água de estudo foi preparada com a mistura da água coletada em Barra Bonita e a cultura com predominância de Microystis, com elevada concentração de microcistina que foi desenvolvida no laboratório. A razão de mistura foi definida para cada etapa de ensaio em função das concentrações de microcistina presente na água de Barra Bonita e na cultura, de maneira a resultar em uma concentração da mistura da ordem de $15 \mu \mathrm{g} \cdot \mathrm{L}^{-1}$.

Após o seu preparo, a água de estudo foi armazenada durante os períodos de ensaio em câmara fria e escura, a uma temperatura de $4,0 \pm 2,0^{\circ} \mathrm{C}$ nas bombonas empregadas para a coleta de água em Barra Bonita. Cada seção de ensaio foi realizada em um período máximo de sete dias, de maneira a evitar longos períodos de armazenamento e a conseqüente degradação da qualidade da água de estudo.

Ao todo, foram feitas cinco sessões de ensaios, sendo que para cada sessão foram preparados cerca de 100 a 120 litros de água de estudo. Portanto, foram preparadas cinco águas de estudo, cujas características qualitativas são apresentadas ao longo do capítulo 5 juntamente com os resultados obtidos em cada sessão de ensaios.

\subsection{2 - Coleta e Caracterização da Água de Barra Bonita}

O reservatório de Barra Bonita está localizado nas Unidades de gerenciamento de Recursos Hídricos Sorocaba Médio Tietê - UGRHI 10 e Piracicaba Capivari Jundiaí UGRHI 5. 
A UGRHI 10 tem como corpos hídricos principais o rio Tietê, desde a saída do reservatório de Pirapora até a barragem do reservatório de Barra Bonita, os rios Sorocaba, Pirajibú, Ipanema, Tatuí e Saparapuí e o reservatório de Itupararanga no rio Sorocaba. O território dessa UGRHI , com área de drenagem de cerca de 11.800 $\mathrm{km}^{2}$, é caracterizado pela presença de grandes centros urbanos do interior do estado, intensa atividade industrial (têxtil, alimentícia, química, mecânica, eletroeletrônica) e rural (culturas temporárias destacando-se a cana de açúcar, pastagens e silvicultura).

A UGRHI 5 tem como corpos hídricos principais os rios Capivara, Jundiaí e Piracicaba, sendo este último, um dos formadores do reservatório de Barra Bonita. $\mathrm{O}$ território dessa UGRHI, com área de drenagem de cerca de $14.200 \mathrm{~km}^{2}$, apresenta ocupação e uso do solo de características semelhantes às da UGRHI 10 descrita anteriormente.

As águas dessas duas unidades de recursos hídricos são destinadas ao abastecimento público e industrial, recepção de efluentes domésticos e industriais, geração de energia elétrica, irrigação e recreação. Conforme a tabela 4.1, em termos de qualidade das águas, o reservatório de Barra Bonita apresentou, para o ano de 2006, os seguintes valores médios anuais dos índices de qualidade instituídos pela CETESB em seu programa de monitoração das águas interiores do Estado de São Paulo (CETESB (2006)). 
Tabela 4.1 - Índices Médios Anuais de Qualidade das Águas do Reservatório de Barra

Bonita -Ano de 2006

Ponto de Localização do Ponto

Monitoração
Índices Médios Anuais

IQA IAP IVA IET

(1) (2) (3) (4)

\begin{tabular}{lllllll}
\hline \hline PCBP 02500 & Braço do rio Piracicaba, na ponte na rodovia & 76 & 71 & 4,6 & 64 \\
& SP 191 que liga Sta Maria a São Manuel & & & & \\
\hline TIBT 02500 & $\begin{array}{l}\text { Braço do rio Tietê, na ponte na rodovia SP } \\
\text { 191 que liga Sta. Maria a São manuel }\end{array}$ & 57 & 7,3 & 66 \\
& Corpo central do reservatório a jusante da & 77 & 77 & 5,8 & 64 \\
& confluência dos rios Tietê e Sorocaba & & & & \\
\hline TIBB 02100 & Corpo central do reservatório na direção do & 69 & 49 & 5,8 & 65 \\
& & & & & \\
\hline
\end{tabular}

1 - IQA - Índice de qualidade das águas

2 - IAP - Índice de qualidade das águas brutas para fins de abastecimento público

3 - IVA - Índice de qualidade das águas para a proteção da vida aquática e de comunidades aquáticas

4 - IET - Índice de estado trófico

Fonte: CETESB (2006)

O IQA é baseado em uma média ponderada de nove parâmetros de controle ambiental considerados relevantes para a avaliação da qualidade das águas, são eles: $\mathrm{pH}$, temperatura, turbidez, resíduo total, oxigênio dissolvido, DBO, nirogênio total, fósforo total e coliformes termotolerantes. Esse índice apresenta o seguinte critério de classificação:

- $\mathrm{IQA} \leq 19$ - Péssimo;

- $19<\mathrm{IQA} \leq 36$ - Ruim;

- $36<\mathrm{IQA} \leq 51$ - Regular;

- $51<\mathrm{IQA} \leq 79$ - Boa;

- $79<\mathrm{IQA} \leq 100$ - Ótima. 
O IAP é a média ponderada do IQA e o ISTO, que é o índice de substâncias tóxicas e organolépticas, que considera metais pesados, metais que alteram as qualidades organolépticas da água (ferro, manganês, alumínio, cobre e zinco), potencial de formação de trialometanos e número de células de cianobatérias. Esse índice apresenta o mesmo critério de classificação do IQA.

O IET classifica o corpo aquático em diferentes graus de trofia, ou seja, avalia a qualidade da água quanto ao enriquecimento por nutrientes e seu efeito relacionado ao crescimento excessivo de algas, cianobactérias e macrófitas aquáticas. Esse índice apresenta o seguinte critério de classificação:

- $\mathrm{IET} \leq 47$ - Ultraoligotrófico;

- $47<\mathrm{IET} \leq 52$ - Oligotrófico;

- $52<\mathrm{IET} \leq 59-$ Mesotrófico;

- $59<\mathrm{IET} \leq 63$ - Eutrófico;

- $63<\mathrm{IET} \leq 67$ - Supereutrófico;

- $\mathrm{IET}>67$ - Hipereutrófico.

O IVA considera contaminantes químicos tóxicos para os organismos aquáticos, $\mathrm{pH}$, oxigênio dissolvido e o grau de trofia do corpo aquático, representado pelo IET. Esse índice apresenta o seguinte critério de classificação:

- IVA $\leq 2,5$ - Ótima;

- $2,6 \leq \mathrm{IVA} \leq 3,3-$ Boa;

- $3,4 \leq$ IVA $\leq 4,5$ - Regular;

- $4,6 \leq$ IVA $\leq 6,7$ - Ruim;

- $6,8 \leq$ IVA - Péssima. 
Tendo em vista os índices de qualidade apresentados na tabela 4.1, observa-se que no ano de 2006 o Reservatório de Barra Bonita apresentou, em média, boas condições de qualidade da água para fins de abastecimento público. Entretanto, o principal problema desse corpo aquático consiste na eutrofização de suas águas devido ao excesso de nutrientes. Os quatro pontos de monitoração indicaram nível supereutrófico considerando o IET. Em termos de proteção da vida aquática os dois pontos localizados no corpo de reservatório e no ponto do braço do rio Piracicaba apresentaram IVA ruim e no braço do rio Tietê IVA péssimo devido à influência da Região Metropolitana de São Paulo.

As coletas de água em Barra Bonita foram realizadas à montante da barragem, na captação de água que alimenta os tanques de piscicultura presentes na represa de Barra Bonita, situados na margem oposta à eclusa ali existente. O ponto de captação está localizado nas seguintes coordenadas: Latitude $-22^{\circ} 31^{\prime} 8,57^{\prime \prime}$, Longitude - $48^{\circ} 31^{\prime} 58,72^{\prime \prime}$.

Na figura 4.1 é apresentada a localização do reservatório de Barra Bonita e das UGRHI's 5 e 10 dentro dos limites do estado de São Paulo, bem como a localização dos pontos de monitoração da CETESB referidos na tabela 4.1. 


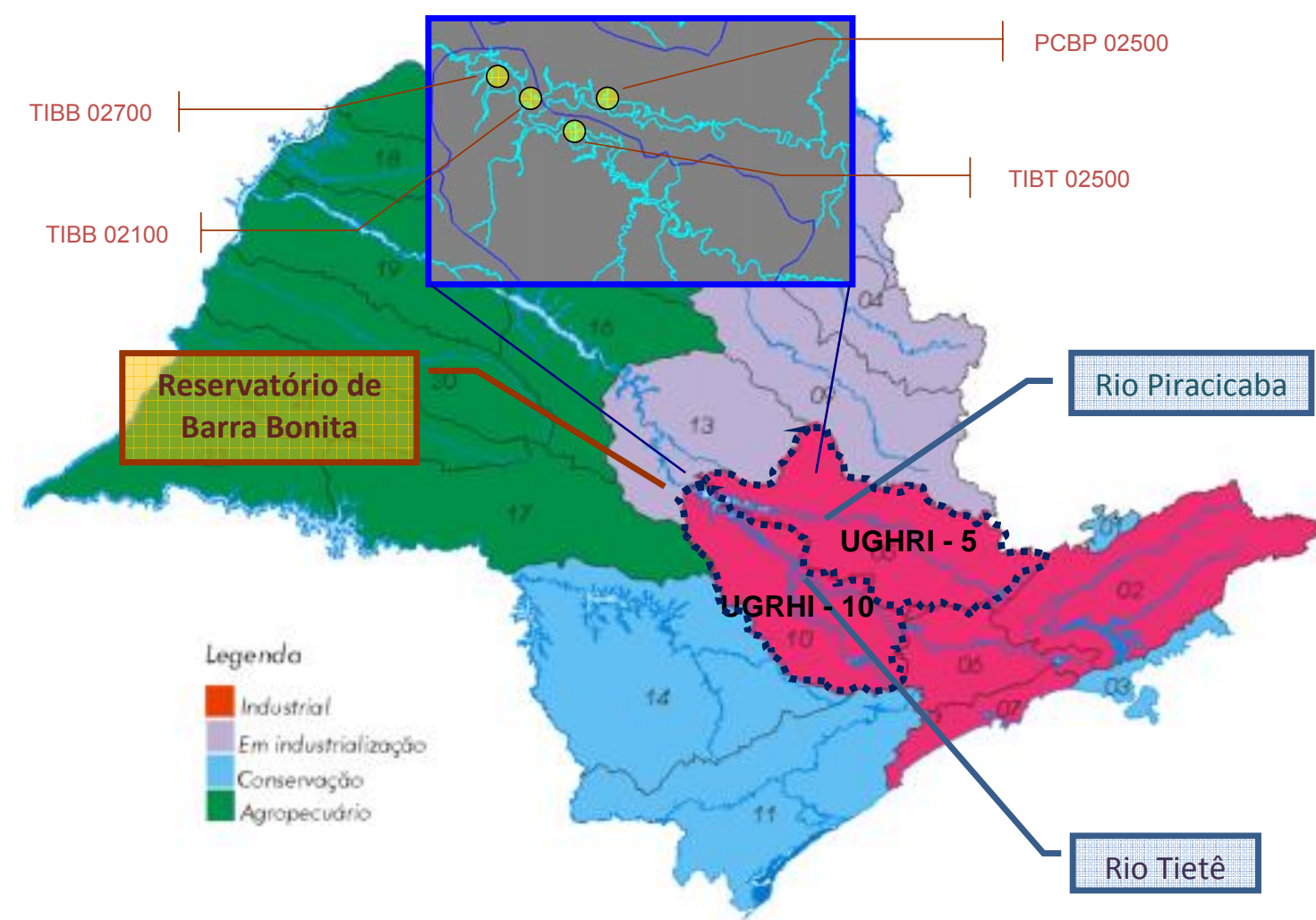

Figura 4.1 - Localização do reservatório de Barra Bonita, das UGRHI's 5 e 10 e dos pontos de monitoração da CETESB

Fonte: CETESB (2006)

\subsection{3 - A Cultura de Cianobactérias}

A cultura de cianobactérias usada para o preparo da água de estudo foi produzida em condições controladas nas dependências do LATAR. Para isso foi implantada uma estrutura específicamente destinada ao cultivo de cepa de Microcystis sp.

O inóculo utilizado - BB05 foi fornecido pelo Prof. Dr. Armando Augusto H. Vieira, do Departamento de Botânica da Universidade Federal de São Carlos, a partir do isolamento de células coletadas no Reservatório do Rio Tiete, em Barra Bonita/SP. No início do trabalho foram cultivados dois inóculos (BB05 e BB17), mas análises preliminares revelaram que a cepa BB05 apresentava maior concentração de 
microcistina que a BB17, por isso foi descartado o cultivo da cepa com menor toxicidade.

O cultivo foi realizado em erlenmeyers de 2L, fechados com tampões confeccionados com algodão hidrófilo e gaze. Foi mantida a aeração constante da cultura com o objetivo de homogeneização da massa líquida e, conseqüentemente, assegurar iguais condições de contato das células com o substrato disponível para o seu desenvolvimento. A figura 4.2 apresenta os frascos utilizados para o cultivo.

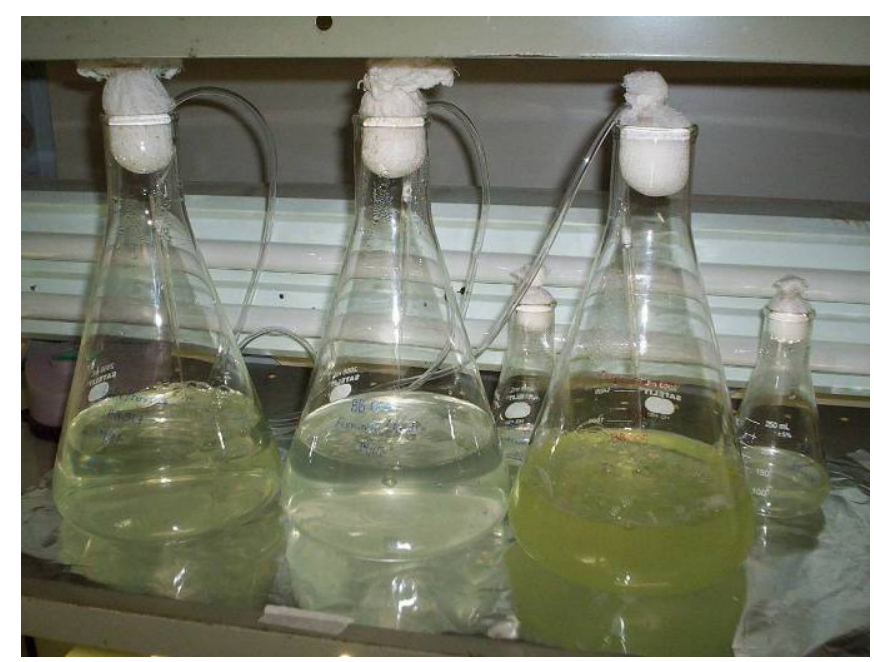

Figura -4.2- Vista dos frascos empregados para o cultivo

Foi usado o método de cultivo Estático ou Batch, que consiste na transferência de parcela das culturas, antes de atingirem a fase de equilíbrio dinâmico aparente de crescimento, para volumes maiores de culturas enriquecidas com nutrientes.

O meio de cultivo usado foi o ASM1, proposto por GORHAM et al., 1964. Foi adotado fotoperíodo de 12 horas, com o uso de lâmpadas fluorescentes brancas e temperatura ambiente de $20 \pm 2^{\circ} \mathrm{C}$, controlada por climatizador externo. 
Foi feito acompanhamento visual do crescimento da cultura e realizaram-se repiques todas as vezes que a cultura adquiria aspecto amarelado, o que ocorria após cerca de 20 a 30 dias. Os procedimentos para minimizar a contaminação da cultura e manter condições adequadas para o cultivo das cianobactérias foram os seguintes:

- Sala de cultivo: A sala de cultivo possui ante-sala para evitar o contato direto com o ambiente interno do LATAR. Essa sala possui climatizador, termômetro com registro da variação de temperatura, local para acomodação da cultura, bancada para manejo com bico de bunsen, coifa superior ligada a um sistema de sucção constante de ar e entrada de ar inferior com filtro. As Figuras 4.3, 4.4 e 4.5 apresentam detalhes da sala de cultivo.

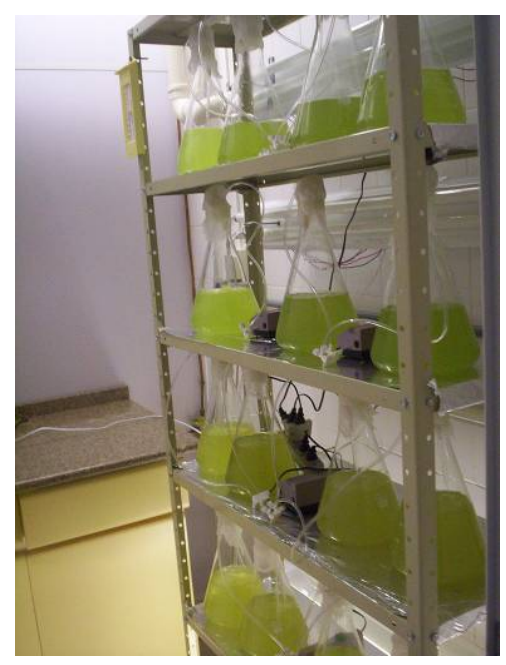

Figura 4.3- Ilustração geral da sala de cultivo.
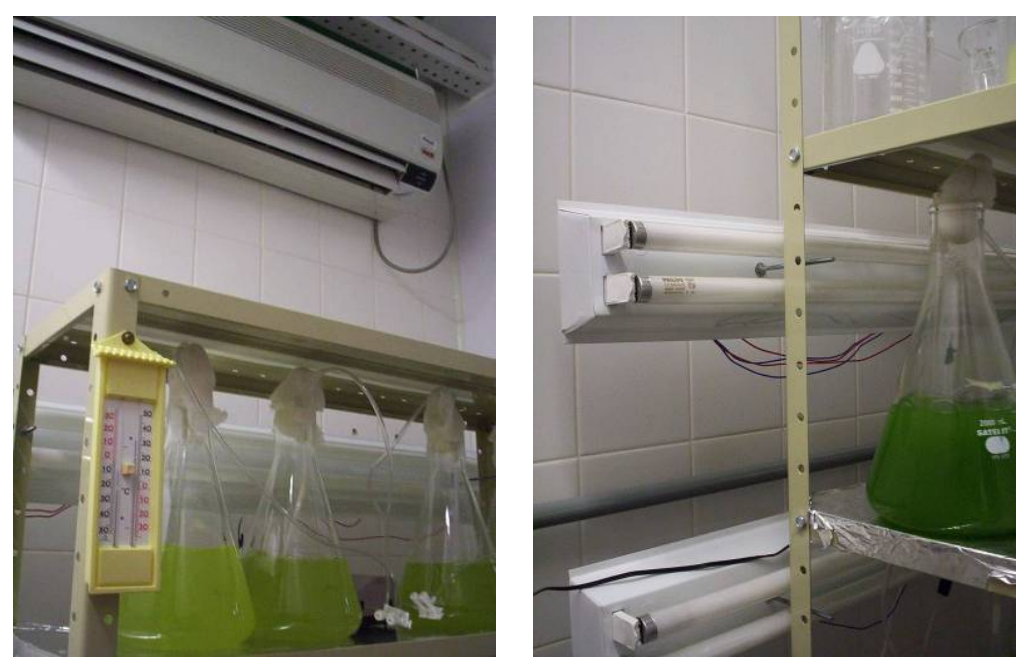

Figura 4.4 - Detalhes do Figura 4.5 - Detalhes das termômetro $e$ do lâmpadas climatizador

- Vidraria: Toda a vidraria usada foi tratada em solução de detergente neutro (EXTRAN 10\%) por no mínimo 12 horas e em ácido clorídrico (10\%), também por no mínimo 12 horas. Na seqüência, foram realizados 6 enxágües com água potável e 3 enxágües com água destilada. Depois de seca, a vidraria era armazenada no interior da sala de cultura, de maneira a ficar isolada das outras dependências do laboratório. 
- Meio de cultura: A água usada para o preparo foi submetida a osmose reversa e o meio de cultura foi preparado em $\mathrm{pH}$ igual a 8,0 $\pm 0,2$ e acondicionado em erlenmeyers. Após serem devidamente fechados com papel alumínio, os erlenmeyers eram autoclavados por 20 minutos a $120^{\circ} \mathrm{C}$ e $1,0 \mathrm{kgf} . \mathrm{cm}^{-2}$. Antes de efetuar o repique, o meio de cultura e toda a vidraria utilizada foram submetidos à esterilização em câmara de radiação de ultravioleta por 20 minutos. As figuras 4.6 e 4.7 mostram detalhes da câmara de radiação ultravioleta empregada.

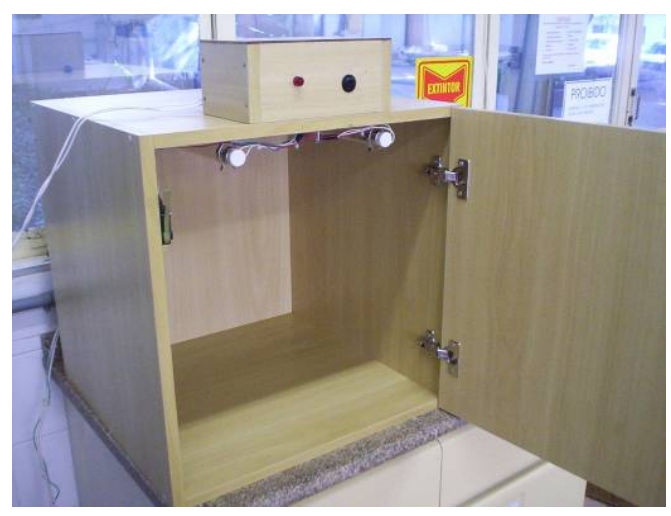

Figura 4.6 - Vista geral da câmara de radiação ultravioleta

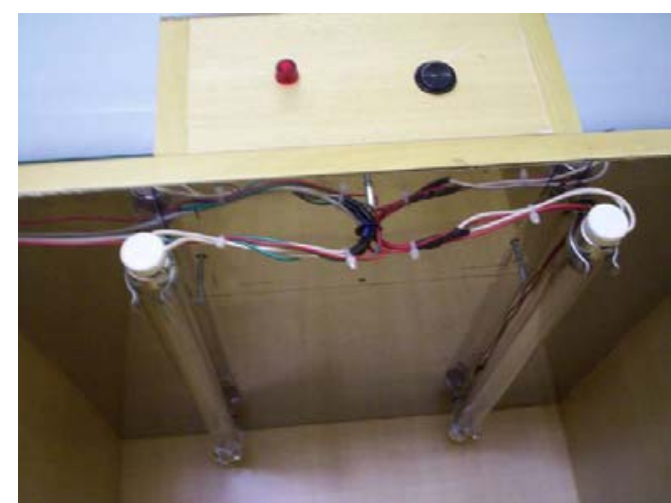

Figura 4.7 - Detalhes das lâmpadas de radiação ultravioleta.

\section{3 - Equipamentos}

Vários equipamentos foram utilizados para a realização dos ensaios em suas diferentes etapas, sendo que ao longo deste capítulo são citados e descritos, oportunamente. Entretanto, existem dois equipamentos que foram de uso comum em praticamente todas as etapas e, portanto, são descritos neste item.

Os ensaios foram realizados em escala de laboratório em equipamentos de coagulação, floculação e sedimentação por batelada em jarros (jartest) e flotateste. Preparada a água de estudo, as amostras foram submetidas à mistura rápida no equipamento jarteste e, após a coagulação as amostras ensaiadas foram transferidas para o equipamento flotateste, que é ilustrado na figura 4.9. para a 
floculação e posterior flotação por ar dissolvido. Em alguns casos as amostras flotadas foram submetidas à filtração à vácuo em papel Whatman 40 .

O jarteste, utilizado possuía seis jarros de formato quadrado com capacidade para 2,0 litros, cada um dotado de turbina do tipo fluxo radial, formada por duas paletas diametralmente opostas, com largura de $4,5 \mathrm{~cm}$ e altura de $2,5 \mathrm{~cm}$. $O$ equipamento utilizado é apresentado na figura 4.8.

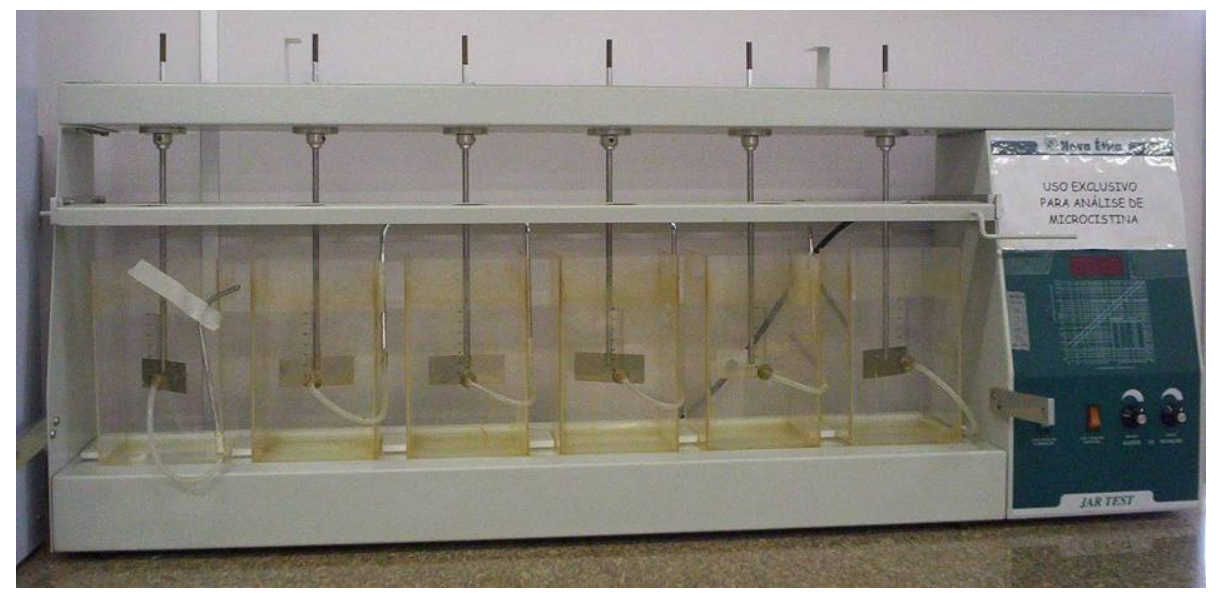

Figura 4.8 - Equipamento de jarteste.

O flotateste, descrito por REALI (1991), é equipamento empregado no LATAR para ensaios de flotação em escala de laboratório e com alimentação por batelada. Esse equipamento possui quatro colunas independentes de flotação construídas em acrílico, cada qual com um agitador removível com ajuste de rotação capaz de imprimir gradientes médios de velocidade na faixa de 10 a $150 \mathrm{~s}^{-1}$. Estas colunas possibilitam a realização das etapas de floculação e flotação. Interligada às quatro colunas de flotação existe uma câmara de saturação pressurizada. Nesta unidade, é borbulhado ar comprimido à alta pressão (faixa de 1,0 a $7,0 \mathrm{kgf}_{\mathrm{cm}} \mathrm{cm}^{-2}$ ), até que a mesma atinja o ponto de saturação para dadas temperaturas e pressão de trabalho. As figuras 4.9 e 4.10 apresentam o equipamento de flotateste utilizado nos ensaios. 


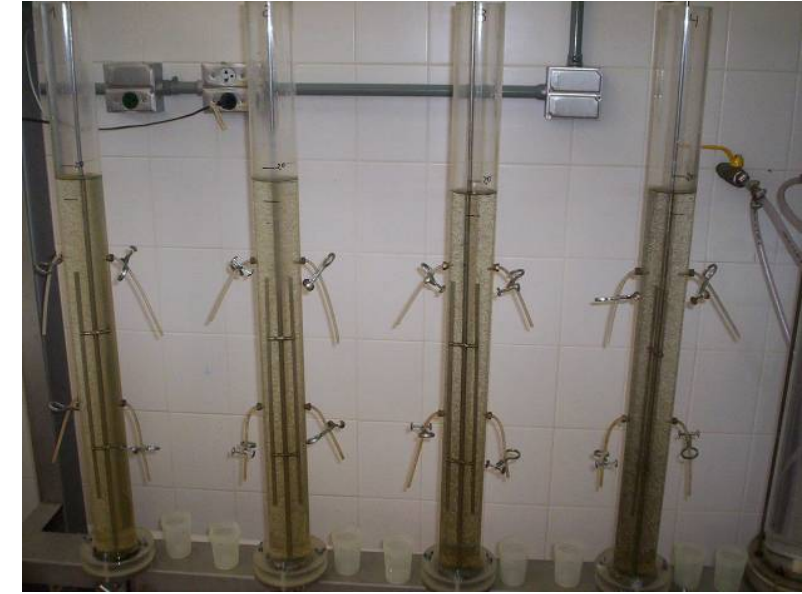

Figura-4.9- Equipamento de flotateste.

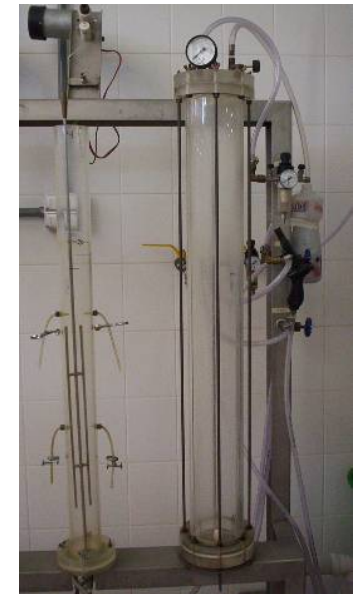

Figura-4.10- Câmara de saturação interligada ao equipamento de flotateste.

\section{4 - Descrição dos Ensaios}

\subsection{1 - Generalidades}

Os ensaios foram realizados segundo cinco baterias distintas, com intervalos regulares entre cada bateria de aproximadamente trinta dias; período este necessário para a adequada maturação da cultura preparada em laboratório e, conseqüentemente, para que houvesse concentração de microcistina extracelular suficiente para o preparo da água de estudo com concentração de microcistina da ordem de $15 \mu \mathrm{g} \cdot \mathrm{L}^{-1}$, conforme citado anteriormente.

Cada bateria de ensaios foi realizada no período máximo de sete dias de maneira a minimizar a degradação natural da microcistina, tanto da água de estudo quanto das amostras decorrentes dos ensaios de oxidação. As dependências do laboratório são climatizadas e todos os ensaios foram realizados com temperatura da água na faixa de 20 a $23^{\circ} \mathrm{C}$.

Os ensaios definitivos, cujos resultados são a base do presente estudo, foram realizados no período de setembro de 2006 a janeiro de 2007. Entretanto, foi necessário um período inicial de aproximadamente seis meses, destinado à 
elaboração e consolidação do método empregado nos ensaios de oxidação, melhoria das instalações e procedimentos analíticos para a determinação da microcistina pelo metodo ELISA, bem como para o desenvolvimento do método de lise celular para a liberação de microcistina intracelular, conforme descrito no item 4.4.2.

$\mathrm{Na}$ figura 4.11 é apresentado o fluxograma geral dos ensaios de oxidação realizados. 


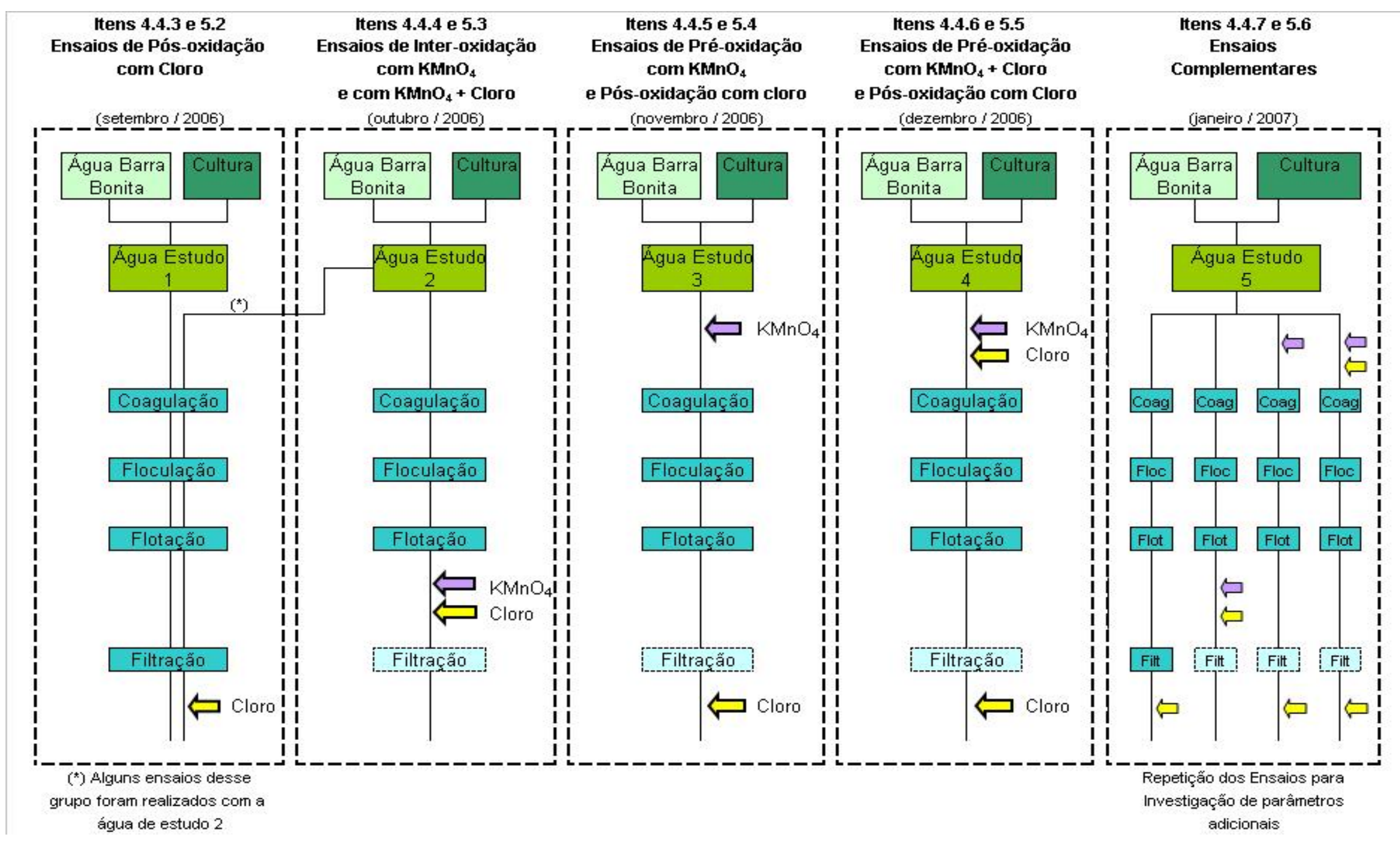

Figura 4.11 - Fluxograma geral dos ensaios 
4.4.2 - Ensaios para Definir o Método de Preparo de Amostras para a Medição de Microcistina Total

Para os ensaios, foi incorporada a medição de microcistina visando uma avaliação aproximada da quantidade total de toxina presente na água de estudo, formada pela soma das parcelas de toxina extracelular e intracelular.

As medições de microcistina realizadas nos trabalhos anteriores realizados pelo grupo de pesquisa são pertinentes à toxina dissolvida no meio líquido, ou seja a toxina "extracelular", sendo que para o conhecimento da quantidade total de microcistina presente na água de estudo torna-se necessário o rompimento das células para a liberação da toxina contida no interior das mesmas, denominada toxina "intracelular".

Com o rompimento celular, portanto, a parcela de microcistina intracelular, que antes não era medida nas determinações analíticas mediante o método ELISA, passa a ser incorporada à parcela extracelular (dissolvida no meio líquido) e, conseqüentemente, passível de medição. Portanto, submetendo a amostra a um efetivo rompimento celular, é possível uma avaliação bastante aproximada da quantidade total de microcistina presente $e$, de forma indireta, a parcela de microcistina intracelular (Parcela intracelular $=$ Total - Parcela extracelular).

Existem diferentes meios de rompimento celular, destacando-se, a aplicação de ultra-som e o congelamento.

A primeira alternativa foi avaliada, de forma preliminar, no início desta fase dos trabalhos, mas foi descartada devido ao funcionamento inadequado do aparelho gerador de ultra-som disponível no laboratório, pois problemas no dispositivo de 
ajuste de potência não permitiam uma precisa avaliação da quantidade de energia aplicada à amostra. Tendo em vista que o ultra-som, além de proporcionar a lise celular, também pode causar a desnaturação da molécula de microcistina com o aumento da energia aplicada à amostra, a adoção do ultra-som para o caso em questão foi considerada inadequada, por haver grande risco de descaracterizar a amostra para a finalidade de medição de micricistina devido à possibilidade de ocorrer uma efetiva remoção da microcistina através da desnaturação de sua molécula e não somente a sua liberação para o meio líquido através da lise celular.

Em contrapartida, a técnica de congelamento, embora seja mais demorada e provavelmente menos eficiente para a lise celular, mostrou-se mais segura para o caso em questão, considerando o risco de desnaturação da molécula de microcistina.

Para avaliar a efetividade da lise celular com o congelamento, quatro amostras de cultura foram submetidas a um número diferente de ciclos de congelamento e descongelamento (1 a 4 ciclos) em um freezer convencional (temperatura abaixo de $\left.-5^{\circ} \mathrm{C}\right)$.

$\mathrm{Na}$ seqüência, para cada amostra, foi feita a contagem e identificação de fitoplancton, bem como a medição de microcistina mediante o método ELISA, sendo que, conforme apresentado no próximo capítulo, os resultados obtidos confirmaram a efetiva lise celular, aprovando a técnica de congelamento para o preparo da amostra para a medição aproximada de microcistina total.

Conforme citado no capítulo 5, observa-se que a medição de microcistina extracelular, feita após a lise provocada pelos ciclos de congelamento e descongelamento, não pode ser considerada representativa da quantidade total de 
toxina, tendo em vista que não foi constatado $100 \%$ de lise celular e existe a possibilidade de que haja microcistina aderida ao material celular remanescente do processo de lise e, portanto, não passível de medição pelo método ELISA. Entretanto, conforme apresentado no item 5.1, foi observada lise celular superior a 99,9 \% e ocorreu aumento bastante significativo de microcistina (cerca de 4 vezes a concentração original da cultura) nas amostras submetidas ao processo de congelamento e descongelamento, indicando, portanto, que a parcela de microcistina que possa estar ainda contida no interior das células não lisadas ou aderida ao material celular disperso pelo meio líquido é, certamente, pouco significativo frente à quantidade que foi medida.

Portanto, em termos práticos, as amostras submetidas à lise celular considerando o método de congelamento e descongelamento praticado neste estudo, seria representativa da concentração total de microcistina formada pelas parcelas intra e extracelular. A determinação da concentração de microcistina intracelular, ainda que de forma aproximada, é muito importante em termos práticos, pois, somada à parcela extracelular, representa o potencial da concentração total de microcistina que pode estar presente no meio líquido quando o fitoplancton é submetido a situações de estresse ou lise celular acentuadas, tais como as causadas pela aplicação de algicidas para o controle de florações, bem como pela permanência dos microrganismos nos decantadores e filtros ou por oxidações enérgicas nos sistemas de tratamento de água.

\subsection{3 - Pós Oxidação Química com Cloro}

\subsubsection{1 - Generalidades}


Os ensaios destinados ao estudo da pós-oxidação química com cloro são relativos ao trabalho de pesquisa citado no item 3.6.5. Esse conjunto de ensaios teve o objetivo de investigar o efeito da oxidação química do cloro para a remoção de microcistina quando esse oxidante é aplicado ao final do fluxograma do processo de tratamento, ou seja, após a filtração da água.

Foram desenvolvidas três etapas, sendo:

- ETAPA I: destinada à tratabilidade da água de estudo, produção da água filtrada necessária para a realização dos ensaios de oxidação e para a determinação da curva de residual de cloro na água filtrada;

- ETAPA II: destinada à oxidação da água filtrada avaliando diferentes condições de dosagem de oxidante e tempos de contato;

- ETAPA III: destinada também à oxidação da água filtrada, mas avaliando a influência da variação do $\mathrm{pH}$ tendo como base a melhor dosagem de oxidante e tempo de contato observados na ETAPA II.

Parte desses ensaios (Etapas I e II) foram realizados no trabalho de iniciação científica citado no item 3.6.5. Entretanto, visando possibilitar ao leitor uma visão integral dos ensaios de pós-oxidação com cloro, nesta tese de doutorado o método e os resultados são apresentados integralmente neste capítulo e no capítulo 5.

A figura 4.12 apresenta o esquema dos ensaios destinados ao estudo da pósoxidação química com cloro e, na seqüência, são descritas as etapas desses ensaios. 


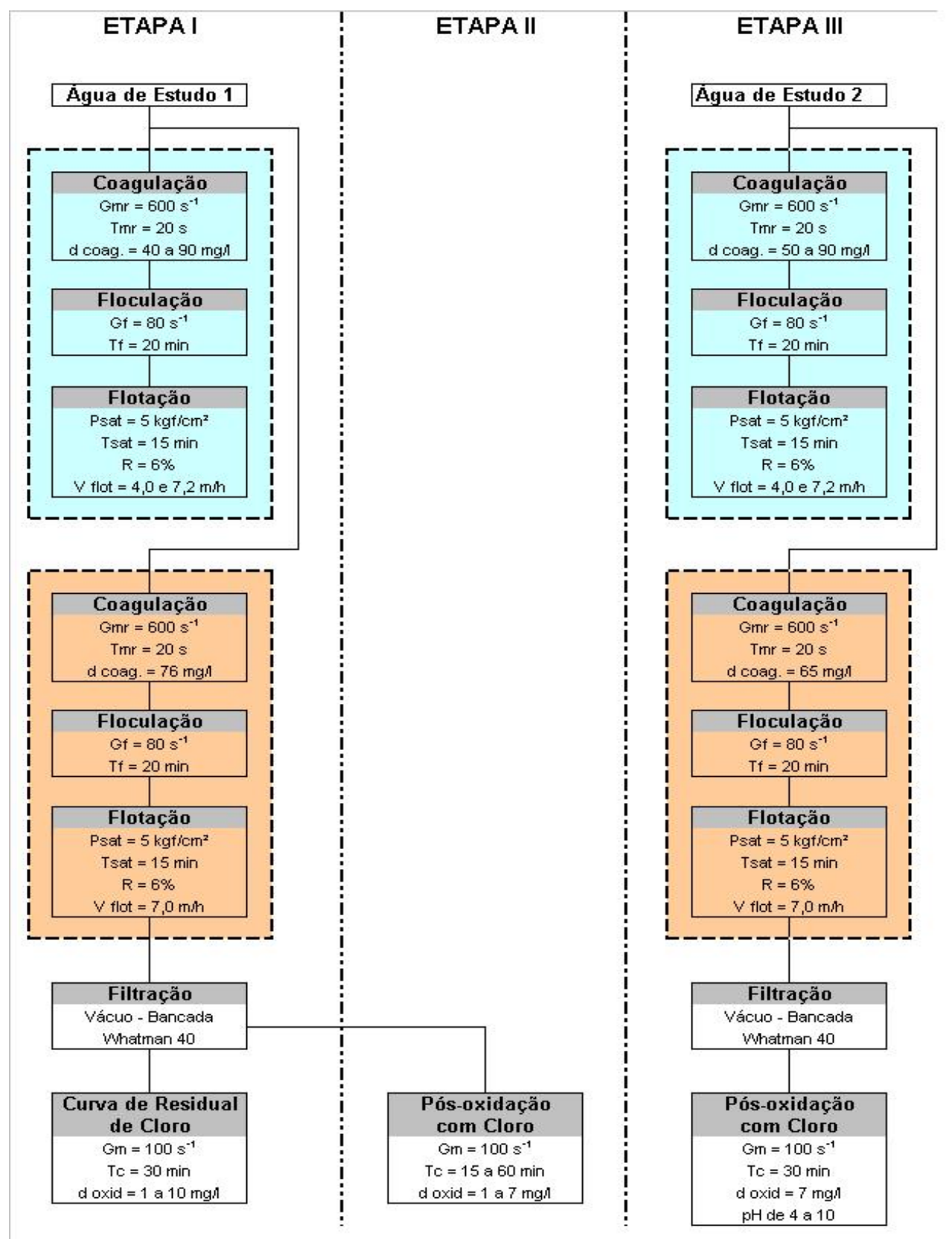

Ensaios para Investigação da Dosagem de Coagulante

Ensaios para a Produção de Água Flotada

Figura 4.12 - Esquema dos Ensaios Destinados ao Estudo da Pós-oxidação Química com Cloro

4.4.3.2 - ETAPA I

Esta etapa foi realizada com a Água de Estudo 1 e pode ser dividida em 3 fases subseqüentes. 


\section{a) Fase I}

$\mathrm{Na}$ primeira fase desta ETAPA I foram realizados ensaios de tratabilidade com o aparelho jar-test, destinado exclusivamente à mistura rápida do coagulante, e posteriormente o aparelho flotatest, destinado à floculação e flotação por ar dissolvido da água coagulada.

Esses ensaios visaram a definição da melhor condição de tratabilidade da água de estudo, em termos de coagulação, através da avaliação de diferentes dosagens de cloreto férrico $\left(50 ; 55 ; 60 ; 65 ; 70 ; 72 ; 74 ; 76 ; 78 ; 80\right.$ e 90 mg.L $\left.\mathrm{L}^{-1}\right)$ e sem a aplicação de substância alcalinizante ou acidificante para a correção de pH. Foi feita a monitoração da cor e turbidez da água submetida à flotação.

Os tempos de mistura, gradientes de velocidade e demais condições físicas de coagulação, floculação e flotação foram fixados para todos os ensaios conforme os valores apresentados a seguir:

- Coagulação:

o Gradiente de velocidade para a mistura rápida : $600 \mathrm{~s}^{-1}$;

o Tempo de mistura : 20 segundos;

- Floculação:

o Gradiente de velocidade para a mistura lenta : $80 \mathrm{~s}^{-1}$;

o Tempo de mistura : 20 minutos;

- Flotação por Ar dissolvido:

o Pressão da câmara de saturação : 5 kgf.cm ${ }^{-2}$;

o Tempo de detenção na câmara de saturação : 15 minutos;

o Velocidades de flotação : 4,0 e 7,2 m.h. ${ }^{-1}$.

\section{b) Fase II}


Nesta segunda fase, os ensaios de coagulação floculação e flotação foram repetidos seis vezes, com o objetivo de produção de água submetida à flotação e, posteriormente, filtrada. A água produzida nesta fase foi utilizada nos ensaios subseqüentes relativos à esta etapa, bem como nos ensaios relativos à ETAPA II descrita na sequência.

Para a realização desses ensaios, a melhor condição de coagulação, floculação e flotação foi adotada (dosagem de cloreto férrico de $76 \mathrm{mg} \cdot \mathrm{L}^{-1}$ ), sendo que a água produzida apresentou padrão de qualidade, em termos de cor e turbidez, compatível com velocidade de flotação da ordem de $7 \mathrm{~m} \cdot \mathrm{h}^{-1}$ ou cerca de $170 \mathrm{~m}^{3} \cdot \mathrm{m}^{-2} \cdot \mathrm{dia}^{-1}$, tendo como base curvas de flotação (cor versus velocidade de flotação e turbidez versus velocidade de flotação) que foram elaboradas nesta fase dos trabalhos.

As curvas de flotação foram elaboradas a partir da repetição do ensaio de flotatest com a melhor condição de coagulação da água de estudo em termos de dosagem de cloreto férrico, sendo que foram coletadas amostras de água para cinco tempos de flotação distintos $(1 ; 2 ; 3 ; 4$ e 5 minutos), equivalentes a velocidades de flotação respectivamente iguais a 430; $215 ; 140 ; 108$ e $86 \mathrm{~m}^{3} \cdot \mathrm{m}^{-2} \cdot \mathrm{dia}^{-1}$.

Na seqüência, a filtração da água submetida à flotação foi feita a vácuo, em bancada, com papel de filtro Whatmam 40.

\section{c) Fase III}

Essa fase teve o objetivo de avaliar a demanda de cloro pela água filtrada produzida na fase anterior através da determinação de curva de residual de cloro. Para tanto, foram aplicadas diferentes dosagens de hipoclorito de sódio e, conseqüentemente, de cloro ativo $\left(1,0 ; 2,0 ; 4,0 ; 6,0 ; 8,0\right.$ e 10 mg.L $\left.\mathrm{L}^{-1}\right)$. Para cada dosagem de cloro 
ativo foi determinada a concentração de cloro residual após tempo de contato de 30 minutos.

O tempo de contato de 30 minutos foi escolhido tendo em vista ser o valor recomendado pela Norma ABNT para o dimensionamento de câmaras de contato em sistemas de tratamento de água em escala real.

Os ensaios de oxidação foram feitos no equipamento jar-test com um volume de amostra de $1000 \mathrm{~mL}$ para cada condição de oxidação e condições de mistura baseadas em uma rotação de $90 \mathrm{rpm}\left(\mathrm{G}=100 \mathrm{~s}^{-1}\right)$. Foi adotada submergência de 6,0 cm das pás do misturador, para evitar a criação de vórtices que pudessem intensificar a liberação de cloro para a atmosfera.

\subsubsection{3 - ETAPA /I}

Com a água filtrada preparada na Fase II da ETAPA I, foram realizados ensaios de oxidação com a aplicação de hipoclorito de sódio segundo diferentes dosagens de cloro ativo $\left(1,0 ; 3,0 ; 5,0\right.$ e 7,0 mg. $\left.\mathrm{L}^{-1}\right)$ e para cada dosagem três tempos de contato $(15 ; 30$ e $60 \mathrm{~min})$.

A exemplo do ensaio de determinação da curva de residual de cloro, os ensaios de oxidação relativos a esta ETAPA II foram realizados no equipamento jar-test com um volume de amostra de água filtrada de $1000 \mathrm{ml}$ para cada condição de oxidação e condições de mistura baseadas em uma rotação de 90 rpm. Novamente foi adotada submergência de $6,0 \mathrm{~cm}$ das pás do misturador para evitar a criação de vórtices.

Ao final do tempo de contato de cada condição de oxidação, foram coletadas duas amostras de água oxidada, uma destinada à medição da microcistina e outra destinada à medição do cloro residual. A medição do cloro residual foi feita logo 
após a tomada de amostra, enquanto que na amostra destinada à medição da microcistina foi adicionado metabissulfito de sódio para interromper a ação oxidante do cloro e, portanto, viabilizar o seu armazenamento em câmara fria por no máximo cinco dias até a medição da microcistina.

\subsubsection{4 - ETAPA III}

Esta ETAPA III foi realizada com outra água de estudo (a Água de Estudo 2) também usada nos ensaios relativos ao item 4.4.4. Portanto, para os ensaios de oxidação relativos a esta etapa foi necessário novo estudo de tratabilidade com a avaliação de diferentes dosagens de cloreto férrico $(50 ; 60 ; 65 ; 70 ; 75 ; 80$ e 90 $\left.m g \cdot L^{-1}\right)$ e condições físicas de coagulação, floculação e flotação similares às praticadas nos ensaios anteriores.

Também foi necessária a produção de água submetida à flotação e posteriormente filtrada, sendo que a dosagem de cloreto férrico adotada foi de $65 \mathrm{mg} \cdot \mathrm{L}^{-1}$. A água produzida apresentou padrão de qualidade, em termos de cor e turbidez, equivalente a uma velocidade de flotação da ordem de $7,0 \mathrm{~m} \cdot \mathrm{h}^{-1}$ ou cerca de $170 \mathrm{~m}^{3} \cdot \mathrm{m}^{-2} \cdot \mathrm{dia}^{-1}$, tendo como base curvas de flotação elaboradas de acordo com o mesmo método descrito no item 4.4.3.2 (b).

Novamente a água submetida à flotação foi filtrada a vácuo com o papel Whatmam 40.

Com a água filtrada foram realizados os ensaios de oxidação, sendo que nesta fase o objetivo foi avaliar a influência da variação do pH na oxidação da microcistina. Portanto, foram separadas cinco amostras de água filtrada e, em quatro amostras, foi adicionado cal ou ácido clorídrico para a definição de diferentes valores de $\mathrm{pH}$; 
em uma das amostras não foi adicionado alcalinizante ou acidificante para a conservação do $\mathrm{pH}$ original da água filtrada produzida.

Foram fixados para todas as amostras uma dosagem de cloro ativo de $7,0 \mathrm{mg} \cdot \mathrm{L}^{-1} \mathrm{e}$ um tempo de contato de oxidação de 30 minutos, tendo em vista esta ser a melhor condição de oxidação de microcistina observada nos ensaios da ETAPA II.

Os ensaios de oxidação seguiram o mesmo método descrito no item 4.4.3.3.

\subsection{4 - Inter-Oxidação Química com Permanganato de Potássio}

\subsubsection{1 - Generalidades}

Esse conjunto de ensaios teve o objetivo de investigar o efeito da oxidação química do permanganato de potássio para a remoção de microcistina quando esse oxidante é aplicado após a flotação da água.

Foram desenvolvidas três etapas, sendo:

- ETAPA I: destinada à tratabilidade da água de estudo, produção de água submetida à flotação, necessária para a realização dos ensaios de oxidação e avaliação da máxima dosagem viável de permanganato de potássio na água após a etapa de flotação sem o comprometimento dos padrões de potabilidade, em termos de cor, turbidez e manganês total, da água filtrada;

- ETAPA II: destinada à oxidação da água submetida à flotação, exclusivamente com o permanganato de potássio avaliando a influência da variação de $\mathrm{pH}$;

- ETAPA III: destinada também à oxidação da água submetida à flotação, mas avaliando a associação do permanganato de potássio e cloro, bem como a influência da variação do pH. 
A figura 4.13 apresenta o esquema dos ensaios destinados ao estudo da interoxidação química com permanganato de potássio e, na seqüência, são descritas as etapas desses ensaios.

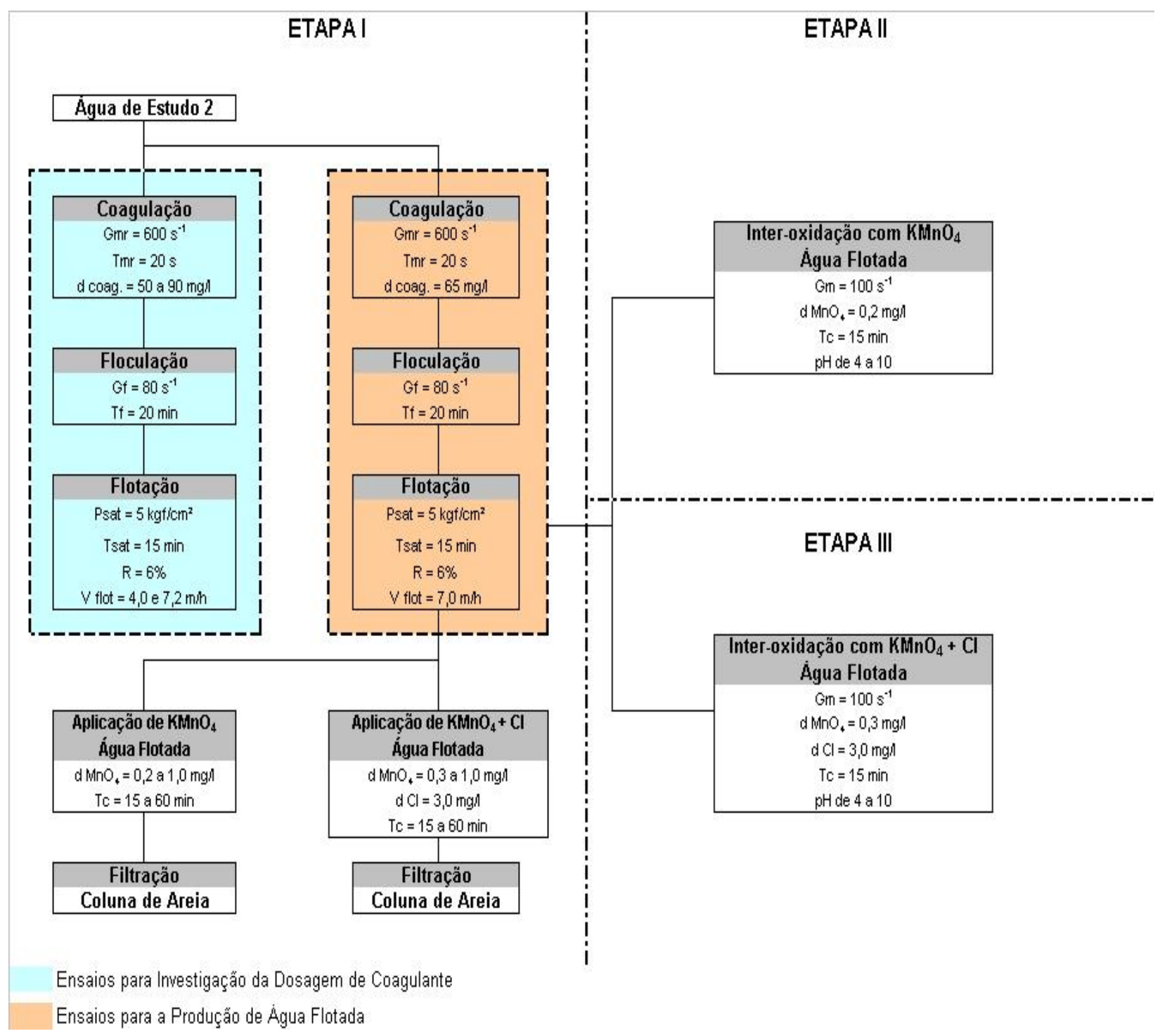

Figura 4.13 - Esquema dos Ensaios Destinados ao Estudo da Inter-oxidação Química com Permanganato de Potássio

4.4.4.2 - ETAPA I

Essa etapa foi realizada com a Água de Estudo 2 e pode ser dividida em 3 fases seqüenciais. 


\section{a) Fase I}

A primeira fase desta ETAPA I visou a definição da melhor condição de tratabilidade da água de estudo, em termos de coagulação, através da avaliação de diferentes dosagens de cloreto férrico $\left(50 ; 60 ; 65 ; 70 ; 75 ; 80\right.$ e 90 mg.L $\left.\mathrm{L}^{-1}\right)$ e sem a aplicação de substância alcalinizante ou acidificante para a correção de $\mathrm{pH}$. Foi feita a monitoração da cor e turbidez da água submetida à flotação.

Os tempos de mistura, gradientes de velocidade e demais condições físicas de coagulação, floculação e flotação são similares aos praticados nos ensaios anteriores.

\section{b) Fase II}

Nesta segunda fase, ensaios de coagulação floculação e flotação foram repetidos várias vezes com o objetivo de produção de água submetida à flotação, que se constituiu na água utilizada nos ensaios subseqüentes relativos a essa ETAPA I e às ETAPAS II e III descritas na sequência. Para a realização desses ensaios, a melhor condição de coagulação, floculação e flotação foi adotada (dosagem de cloreto

férrico de $65 \mathrm{mg} \cdot \mathrm{L}^{-1}$ ), sendo que a água produzida apresentou padrão de qualidade, em termos de cor e turbidez, equivalente a uma velocidade de flotação da ordem de $7,0 \mathrm{~m} \cdot \mathrm{h}^{-1}$ ou cerca de $170 \mathrm{~m}^{3} \cdot \mathrm{m}^{-2} \cdot \mathrm{dia}^{-1}$, tendo como base curvas de flotação elaboradas de acordo com o mesmo método descrito no item 4.4.3.2 (b).

\section{c) Fase III}

Os ensaios desta fase tiveram o objetivo de avaliar a qualidade da água filtrada devido ao impacto da aplicação do permanganato de potássio na água submetida à 
flotação, no que tange os parâmetros cor, turbidez e concentração de manganês total.

Como citado no capítulo 3 o permanganato de potássio pode conferir, principalmente, cor excessiva à água tratada e aumento da concentração de manganês total, dependendo de sua dosagem e das condições de remoção dos óxidos mangânicos formados ao longo do processo de oxidação. O aumento da cor e concentração de manganês total pode comprometer os padrões de potabilidade da água produzida e, conseqüentemente, inviabilizar o emprego do permanganato de potássio dependendo de sua dosagem e condições de oxidação.

A água submetida à flotação produzida na Fase II foi também utilizada para a realização dos ensaios desta fase, que pode ser dividida em dois grupos distintos:

- No primeiro grupo foi avaliado o efeito isolado da aplicação do permanganato de potássio na água submetida à flotação. Para tanto, foi definido para cada amostra de água diferentes dosagens de permanganato de potássio $(0,2 ; 0,3 ; 0,5$ e 1,0 $\mathrm{mg} \cdot \mathrm{L}^{-1}$ de $\mathrm{MnO}_{4}{ }^{-}$), e dois tempos de contato para a reação de oxidação (15 e 60 minutos).

- No segundo grupo foi avaliada a associação do permanganato de potássio e do cloro aplicados na água submetida à flotação, de forma a verificar se o efeito oxidativo adicional do cloro pode contribuir para a remoção dos óxidos mangânicos formados devido à presença do permanganato de potássio. Para tanto foi fixada a dosagem de $3,0 \mathrm{mg} \cdot \mathrm{L}^{-1}$ de cloro ativo associada a diferentes dosagens de permanganato $\left(0,3\right.$ e $\left.0,5 \mathrm{mg} \cdot \mathrm{L}^{-1}\right)$ para um tempo de contato para a reação de oxidação fixado em 15 minutos.

Os ensaios de oxidação seguiram o mesmo método descrito no item 4.4.3.3.

Após a oxidação a água foi submetida a um processo de filtração em coluna de areia (escala de bancada) segundo uma taxa de aplicação superficial de cerca de 200 
$\mathrm{m}^{3} \cdot \mathrm{m}^{-2} \cdot \mathrm{dia}^{-1}$, de forma a representar de forma mais fiel as condições de filtração em escala real. A seguir são apresentadas as principais características do filtro utilizado:

- Altura total da unidade: $2.770 \mathrm{~mm}$;

- Altura do leito filtrante: $1.000 \mathrm{~mm}$;

- Altura da camada suporte: 250 mm;

- Diâmetro da coluna de filtração: 19 mm;

- Leito filtrante: leito constituído de areia com coeficiente de uniformidade de 1,15 $\mathrm{mm}$, tamanho efetivo (Te) de 0,87 mm;

- Camada suporte de pedregulho, sendo:

o camada superior em contato com a areia: altura de $90 \mathrm{~mm}$, granulometria com $\varnothing 2,4$ a $1,4 \mathrm{~mm}$;

o Camada intermediária: altura de $80 \mathrm{~mm}$, granulometria com $\varnothing 4,8$ a 2,4 $\mathrm{mm}$;

o Camada inferior: altura de $80 \mathrm{~mm}$, granulometria com $\varnothing 6,3$ a 4,8 mm.

Exclusivamente para esses ensaios de verificação do efeito da aplicação do permanganato de potássio na qualidade da água tratada final, a filtração a vácuo em bancada (papel Whatmam 40) foi substituída pela filtração em coluna de areia, pois a primeira apresenta desempenho não representativo da realidade em estações de tratamento de água. Caso fosse adotada a filtração a vácuo, certamente os resultados seriam comprometidos com uma subestimativa das dosagens de permanganato de potássio viáveis de aplicação na água submetida à flotação.

Após a filtração em coluna de areia, foi medida a cor e a turbidez da água oxidada e filtrada, bem como separada e preservada amostra para a determinação do manganês total. 
Para garantir a taxa de filtração anteriormente citada, o tempo de filtração foi de cerca de 20 minutos para todas as condições ensaiadas. Portanto, os efetivos tempos de contato totais para a reação de oxidação, foram equivalentes aos tempos definidos para cada condição de oxidação majorados em 20 minutos.

\subsubsection{3 - ETAPA /I}

Com a água submetida à flotação produzida na Fase II da ETAPA I, foram realizados os ensaios de oxidação com o permanganato de potássio, sendo que nesta fase o objetivo foi o de avaliar a dosagem permanganato definida na Fase II da ETAPA I e a influência da variação do pH na oxidação da microcistina. Portanto, foram separadas cinco amostras de água submetida à flotação e, em quatro amostras, foi adicionado cal ou ácido clorídrico para a definição de diferentes valores de $\mathrm{pH}$; em uma das amostras não foi adicionado alcalinizante ou acidificante para a conservação do pH original da água após a flotação.

Foi fixada para todas as amostras dosagem de $\mathrm{MnO}_{4}^{-}$de $0,2 \mathrm{mg} \cdot \mathrm{L}^{-1}$ e tempo de contato de oxidação de 15 minutos, tendo em vista esta ser a máxima dosagem viável definida com os resultados da Fase III da ETAPA I, para o atendimento do padrõa de potabilidade relacionado à cor, turbidez e concentração remanescente de manganês total.

Novamente, os ensaios de oxidação seguiram o método descrito no item 4.4.3.3.

\subsubsection{4 - ETAPA III}

Os ensaios dessa etapa foram similares aos descritos no item anterior, diferindo apenas com relação à melhor condição de ensaio verificada para a associação do permanganato de potássio com o cloro aplicados na água submetida à flotação, ou 
seja: $0,3 \mathrm{mg} \cdot \mathrm{L}^{-1}$ de permanganato associada a $3,0 \mathrm{mg} \cdot \mathrm{L}^{-1}$ de cloro aplicados sequencialmente ( 1 minuto de intervalo entre cada aplicação). Novamente, a dosagem de $0,3 \mathrm{mg} \cdot \mathrm{L}^{-1}$ de permanganato foi adotada devido a ser a máxima dosagem viável, quando a aplicação de permanganato de potássio foi feita em conjunto com o cloro, conforme definido em função dos resultados da Fase III da ETAPA I.

Ao final do tempo de contato de cada condição de oxidação, foram coletadas duas amostras de água oxidada, uma destinada à medição da microcistina e outra destinada à medição das concentrações residuais de permanganato e cloro. A medição do residual dos oxidantes foi feita logo após a tomada da amostra, enquanto que na amostra destinada à medição da microcistina foi adicionado metabissulfito de sódio para interromper a ação oxidante e, portanto, viabilizar o seu armazenamento em câmara fria por no máximo cinco dias até a medição da microcistina.

4.4.5 - Pré-Oxidação com Permanganato de Potássio Associada à Pós-Oxidação com Cloro

\subsubsection{1 - Generalidades}

Esse conjunto de ensaios teve o objetivo de investigar o efeito da pré-oxidação química do permanganato de potássio, associada à pós-oxidação química com cloro para a remoção de microcistina.

Foram desenvolvidas duas etapas, sendo:

- ETAPA I: destinada à tratabilidade da água de estudo e avaliação da máxima dosagem viável de permanganato de potássio na água de estudo sem o comprometimento dos padrões de potabilidade da água tratada; 
- ETAPA II: destinada aos ensaios de pré-oxidação com permanganato de potássio associado à pós-oxidação com cloro, bem como a influência da variação do pH no estágio de pós-oxidação.

A figura 4.14 apresenta o esquema dos ensaios destinados ao estudo da associação da pré-oxidação com permanganato de potássio e pós-oxidação com cloro. $\mathrm{Na}$ seqüência são descritas as etapas desses ensaios. 


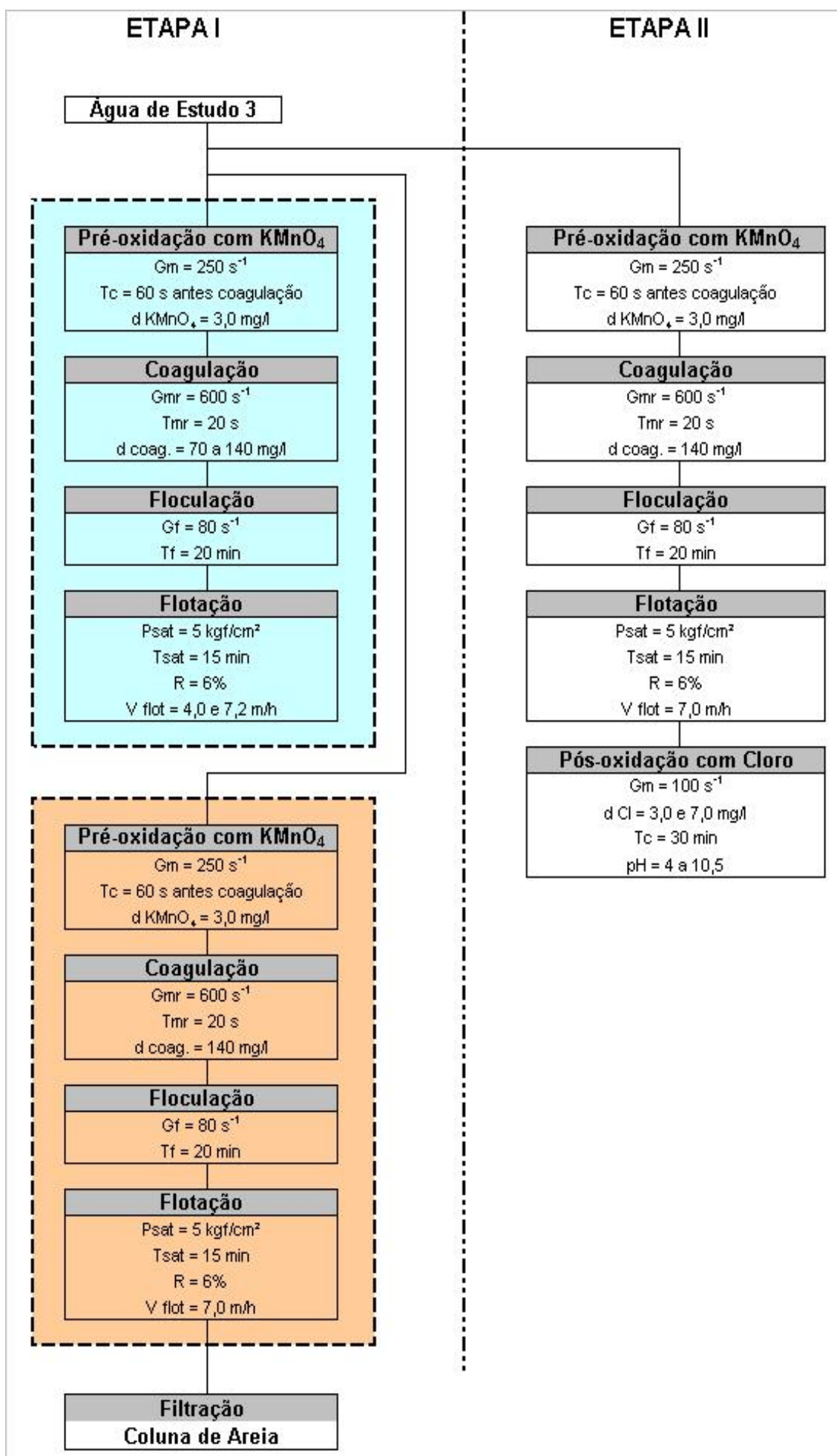

Ensaios para Investigaçẫo da Dosagem de Coagulante

Ensaio para a Produçẫo de Água Flotada

Figura 4.14 - Esquema dos Ensaios Destinados ao Estudo da Associação da Pré-oxidação com Permanganato de Potássio e Pós-oxidação com Cloro 


\subsubsection{2 - ETAPA I}

Essa etapa foi realizada com a Água de Estudo 3 e pode ser dividida em 2 fases subseqüentes.

\section{a) Fase I}

A primeira fase desta ETAPA I visou a definição da melhor condição de tratabilidade da água de estudo no que tange à sua coagulação, floculação e flotação através da avaliação de diferentes dosagens de cloreto férrico $(70 ; 80 ; 90 ; 100 ; 110 ; 120$;

130 e $140 \mathrm{mg} \cdot \mathrm{L}^{-1}$ ) e dosagem de permanganato de $3,0 \mathrm{mg} \cdot \mathrm{L}^{-1}$ definida previamente nesta fase como viável de ser aplicada sem comprometer a qualidade da água filtrada final. A exemplo dos ensaios anteriores não foi aplicada substância alcalinizante ou acidificante para a correção de pH.

Os tempos de mistura, gradientes de velocidade e demais condições físicas de coagulação, floculação e flotação foram similares aos praticados nos ensaios anteriores.

\section{b) Fase II}

Na segunda fase, o ensaio da fase anterior foi repetido com o objetivo de produção de água submetida à flotação e, posteriormente filtrada em coluna de areia, visando a determinação da cor, turbidez e concentração de manganês total na amostra de água fitrada.

Dessa forma, nesta fase foi verificado se a dosagem de permanganato de potássio definida previamente na Fase I não comprometeu os padrões de potabilidade da água filtrada final. Conforme pode ser observado posteriormente no capítulo 5, a 
dosagem de permanganato de $3,0 \mathrm{mg} \cdot \mathrm{L}^{-1}$ foi viável e, portanto, não foi necessária a realização de ensaios adicionais para a investigação de dosagens menores para evitar o comprometimento da água filtrada em termos de cor, turbidez e concentração de manganês total.

Para a repetição do ensaio da fase I, a melhor condição de coagulação, floculação e flotação foi adotada (dosagem de cloreto férrico de $140 \mathrm{mg} \cdot \mathrm{L}^{-1}$ ), sendo que para a água produzida foi verificado, em termos de cor e turbidez, padrão de qualidade equivalente a velocidade de flotação da ordem de $7,0 \mathrm{~m} \cdot \mathrm{h}^{-1}$ ou cerca de $170 \mathrm{~m}^{3} \cdot \mathrm{m}^{-}$ ${ }^{1}$.dia ${ }^{-1}$, tendo como base curvas de flotação elaboradas segundo a metodologia descrita no item 4.4.3.2 (b).

Após a filtração em coluna de areia, foram medidas a cor e a turbidez da água oxidada e filtrada, bem como foi separada e preservada amostra para a determinação do manganês total.

As mesmas condições de filtração em coluna de areia adotadas para os ensaios anteriores foram mantidas, ou seja: tempo de filtração de cerca de 20 minutos e taxa de aplicação superficial de cerca de $200 \mathrm{~m}^{3} \cdot \mathrm{m}^{-2} \cdot \mathrm{dia}^{-1}$. Considerando que o tempo médio demandado pelas etapas de coagulação, floculação e flotação foi de cerca de 30 minutos, o tempo de contato total para a reação de oxidação foi de cerca de 50 minutos.

\subsubsection{3- ETAPA /I}

Para essa etapa os procedimentos relativos à Fase II foram repetidos até o estágio de floculação, ou seja: aplicação de permanganato de potássio $\left(3,0 \mathrm{mg} \cdot \mathrm{L}^{-1}\right)$ e cloreto férrico (140 mg. $\left.\mathrm{L}^{-1}\right)$, coagulação, floculação e flotação. 
Dessa forma, foi produzida água pré-oxidada com permanganato de potássio e submetida à flotação, para os ensaios de pós oxidação com cloro, que foram separados em dois grupos distintos: um com dosagem de cloro de $3,0 \mathrm{mg} \cdot \mathrm{L}^{-1}$ e outro com dosagem de cloro de $7,0 \mathrm{mg} \cdot \mathrm{L}^{-1}$.

Para cada grupo de ensaios foram separadas cinco amostras de água submetida à flotação e, em quatro amostras, foi adicionado cal ou ácido clorídrico para a definição de diferentes valores de $\mathrm{pH}$; em uma das amostras não foi adicionado alcalinizante ou acidificante para a conservação do pH original da água submetida à flotação produzida.

Foi fixado para os dois grupos tempo de contato de oxidação de 30 minutos e os ensaios de oxidação foram realizados de acordo com o mesmo método descrito no item 4.4.3.3.

4.4.6 - Pré-Oxidação com Permanganato de Potássio e Cloro Associada à PósOxidação com Cloro

\subsubsection{1 - Generalidades}

Esses ensaios são bastante semelhantes aos descritos no item anterior, com exceção da aplicação de cloro associado ao permanganato de potássio antes da coagulação da água de estudo.

Foram desenvolvidas duas etapas, sendo:

- ETAPA I: destinada à tratabilidade da água de estudo e avaliação da máxima dosagem viável de permanganato de potássio na água de estudo sem o comprometimento dos padrões de potabilidade, em termos de cor, turbidez e concentração de manganês total, da água filtrada; 
- ETAPA II: destinada aos ensaios de pré-oxidação com permanganato de potássio e cloro associado à pós-oxidação com cloro, bem como a influência da variação do pH no estágio de pós-oxidação.

$\mathrm{Na}$ figura 4.15 é apresentado o esquema dos ensaios destinados ao estudo da associação da pré-oxidação com permanganato de potássio e cloro e pós-oxidação com cloro.

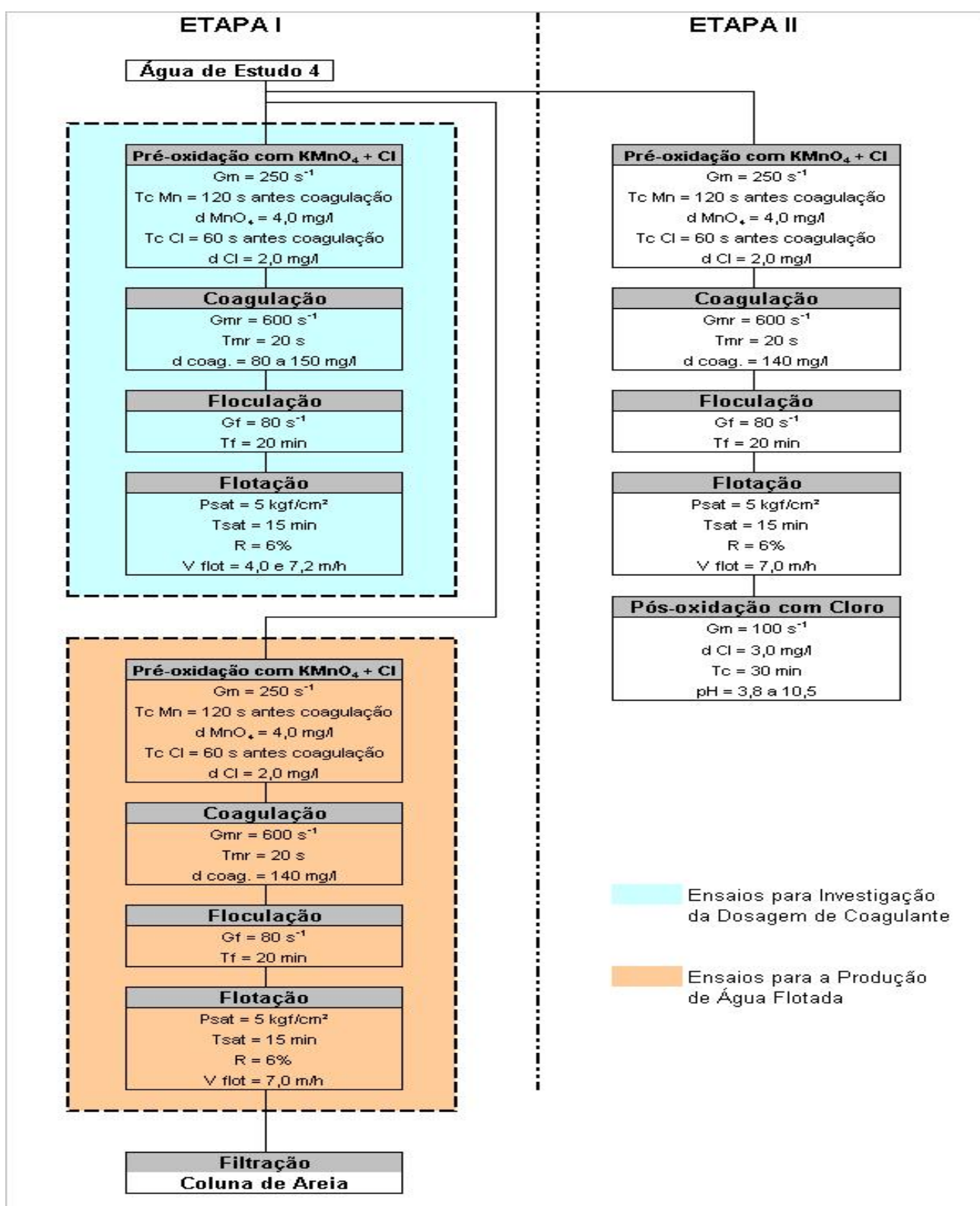

Figura 4.15 - Esquema dos Ensaios Destinados ao Estudo da Associação da Pré-oxidação com Permanganato de Potássio e Cloro e Pós-oxidação com Cloro 


\subsubsection{2 - ETAPA I}

Essa etapa foi realizada com a Água de Estudo 4 e pode ser dividida em 2 fases sequenciais.

\section{a) Fase I}

A primeira fase dessa ETAPA I visou a definição da melhor condição de tratabilidade da água de estudo em termos de coagulação através da avaliação de diferentes dosagens de cloreto férrico $\left(80 ; 100 ; 120 ; 130 ; 135 ; 140 ; 145\right.$ e 150 mg.L $\left.{ }^{-1}\right)$ e aplicação de permanganato de potássio com dosagem de $\mathrm{MnO}_{4}^{-}$de $4,0 \mathrm{mg} \cdot \mathrm{L}^{-1}$, definida previamente nessa fase como viável de ser aplicada sem comprometer a qualidade da água filtrada final, associada à aplicação de cloro com dosagem de 2,0 mg. $\mathrm{L}^{-1} \mathrm{~A}$ exemplo dos ensaios anteriores não foi aplicada substância alcalinizante ou acidificante para a correção de $\mathrm{pH}$.

O permanganato de potássio foi aplicado 120 segundos antes da coagulação e o cloro foi aplicado 60 segundos antes da coagulação.

Os tempos de mistura, gradientes de velocidade e demais condições físicas de coagulação, floculação e flotação foram similares aos praticados nos ensaios anteriores.

\section{b) Fase II}

$\mathrm{Na}$ segunda fase, o ensaio de pré-oxidação (permanganato de potássio + cloro) coagulação floculação e flotação foi repetido com o objetivo de produção de água submetida à flotação e posteriormente filtrada em coluna de areia, visando a 
determinação da cor, turbidez e concentração de manganês total da amostra de água fitrada.

Dessa forma, nessa fase foi verificado se a dosagem de permanganato de potássio definida previamente na Fase I não comprometia os padrões de potabilidade da água filtrada final. Conforme pode ser observado posteriormente no capítulo 5, a dosagem de $\mathrm{MnO}_{4}^{-}$de 4,0 mg..-1 foi viável e, portanto, não foi necessária a realização de ensaios adicionais para a investigação de dosagens menores para evitar o comprometimento da água filtrada em termos de cor, turbidez e concentração de manganês total.

Para a realização desses ensaios, a melhor condição de coagulação, floculação e flotação foi adotada (dosagem de cloreto férrico de $140 \mathrm{mg}^{\mathrm{L}} \mathrm{L}^{-1}$ ), sendo que a água produzida apresentou padrão de qualidade, em termos de cor e turbidez, equivalente a velocidade de flotação da ordem de $7,0 \mathrm{~m} \cdot \mathrm{h}^{-1}$ ou cerca de $170 \mathrm{~m}^{3} \cdot \mathrm{m}^{-2} \cdot \mathrm{dia}^{-1}$, tendo como base curvas de flotação elaboradas conforme o método descrito no item 4.4.3.2 (b).

Após a filtração em coluna de areia, foi medida a cor e a turbidez da água oxidada e filtrada, bem como separada e preservada amostra para a determinação da concentração de manganês total.

As mesmas condições de filtração em coluna de areia adotada para os ensaios anteriores foram mantidas, ou seja: tempo de filtração de cerca de 20 minutos e taxa de aplicação superficial de cerca de $200 \mathrm{~m}^{3} \cdot \mathrm{m}^{-2} \cdot \mathrm{dia}^{-1}$. Considerando que o tempo médio demandado pelas etapas de coagulação, floculação e flotação foi de cerca de 30 minutos, o tempo de contato total para a reação de oxidação foi de cerca de 50 minutos. 
Na ETAPA II os procedimentos relativos à Fase II da ETAPA I foram repetidos até o estágio de flotação, com o objetivo de produzir água pré-oxidada com permanganato de potássio e cloro e posteriormente submetida à flotação, para a realização dos ensaios de pós oxidação com cloro.

Para os ensaios de pós-oxidação foi adotada dosagem de cloro de $3,0 \mathrm{mg} / \mathrm{L}^{-1} \mathrm{e}$ novamente foram separadas cinco amostras de água submetida à flotação. Em quatro amostras foi adicionado cal ou ácido clorídrico para a definição de diferentes valores de $\mathrm{pH}$; em uma das amostras não foi adicionado alcalinizante ou acidificante para a conservação do pH original da água submetida à flotação produzida.

Foi fixado tempo de contato de 30 minutos e os ensaios de oxidação foram realizados de acordo com o mesmo método descrito no item 4.4.3.3.

\subsection{7 - Ensaios Complementares}

Os ensaios complementares tiveram o objetivo de avaliar todos os fluxogramas de tratamento estudados com relação aos seguintes parâmetros de controle adicionais: carbono orgânico total (COT), $\mathrm{NH}_{4}$, clorofila - a, contagem e identificação de fitoplancton e trialometanos.

De maneira a permitir uma mesma base de avaliação, os ensaios complementares foram realizados de acordo com os mesmos métodos definidos para os ensaios anteriores.

Para cada fluxograma de tratamento não foram repetidas todas as condições de ensaio em termos de variação de dosagens, tempos de contato para oxidação etc. 
Foram adotadas apenas as melhores condições de oxidação para a remoção de microcistina observadas em cada ensaio, tal como apresentado na tabela 4.2.

Os ensaios complementares foram realizados com a água de estudo 5 , sendo que foram necessários novos estudos de tratabilidade com os aparelhos jar-test e flotatest para a definição das melhores dosagens de cloreto férrico para a coagulação, floculação e flotação. 
Tabela 4.2 - Condições dos Ensaios Complementares

\begin{tabular}{|c|c|c|c|c|c|}
\hline Ensaio & $\begin{array}{l}\text { Dosagem de } \\
\text { Coagulante } \\
\left(\mathrm{mg}^{-L^{-1}}\right)\end{array}$ & $\begin{array}{l}\text { Dosagem de } \\
\text { Cloro Ativo } \\
\left(\mathrm{mg} \mathrm{Cl}_{2} \cdot \mathrm{L}^{-1}\right)\end{array}$ & $\begin{array}{c}\text { Dosagem de } \\
\text { Permanganato } \\
\left(\mathrm{mg} \mathrm{MnO}_{4}^{-} \cdot \mathrm{L}^{-1}\right)\end{array}$ & $\begin{array}{l}\text { Tempo de contato } \\
\text { (pós-oxidação) } \\
\text { (minutos) }\end{array}$ & $\begin{array}{c}\text { pH da água a ser } \\
\text { oxidada }\end{array}$ \\
\hline Pós-oxidação com cloro & 55 & 7,0 & - & 30 & 7,5 (A Filt) \\
\hline $\begin{array}{l}\text { Inter-oxidação com permanganato de } \\
\text { potássio }\end{array}$ & 55 & - & 0,2 & 15 & 7,5 (A Flot) \\
\hline $\begin{array}{l}\text { Inter-oxidação com a associação de } \\
\text { permanganato de potássio e cloro }\end{array}$ & 55 & 3,0 & 0,3 & 15 & 7,5 (A Flot) \\
\hline $\begin{array}{l}\text { Pré-oxidação com permanganato de } \\
\text { potássio e pós-oxidação com cloro }\end{array}$ & 95 & $\begin{array}{l}\text { 3,0 (pós- } \\
\text { oxidação) } \\
\text { 7,0 (pós- } \\
\text { oxidação) }\end{array}$ & 3,0 & 30 & 6,1 (A Flot) \\
\hline $\begin{array}{l}\text { Pré-oxidação com a associação de } \\
\text { permanganato de potássio e cloro e pós- } \\
\text { oxidação com cloro }\end{array}$ & 95 & $\begin{array}{l}\text { 2,0 (pré- } \\
\text { oxidação) } \\
\text { 3,0 (pós- } \\
\text { oxidação) }\end{array}$ & 4,0 & 30 & 6,2 (A Filt) \\
\hline
\end{tabular}




\section{5 - Determinações Analíticas}

\subsection{1 - Generalidades}

As determinações físico-químicas dos parâmetros de controle adotados nos ensaios foram realizadas de acordo com os procedimentos preconizados pelo Standard

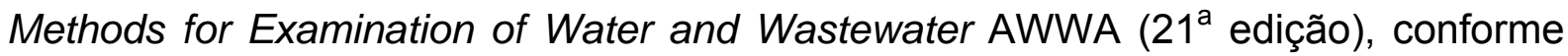
os protocolos identificados na tabela 4.3.

Tabela 4.3 - Protocolos de Determinação Analítica dos Parâmetros de Controle Adotados, de acordo com o Standard Methods for the Examination of Water and Wastewater.

\begin{tabular}{lc}
\hline \hline Parâmetro de Controle & Número do Protocolo \\
\hline \hline $\mathrm{pH}$ & (potenciométrico) \\
\hline Cor & $2120-\mathrm{C}$ \\
\hline Turbidez & $2130-\mathrm{B}$ \\
\hline DQO - Demanda Química de Oxigênio & $5220-\mathrm{D}$ \\
\hline COT - Carbono Orgânico Total & 5310 - B \\
\hline NTK - Nitrogênio Kjeldhal Total & $4500-\mathrm{N}$ - B \\
\hline Nitrogênio Amoniacal & $4500-\mathrm{NH}$ - C \\
\hline Alcalinidade & $2320-\mathrm{B}$ \\
\hline Absorbância a 254 nm & $5910-\mathrm{B}$ \\
\hline Trialometanos & $6232-\mathrm{D}$ \\
\hline Cloro & $4500-\mathrm{G}$ \\
\hline Permanganato & $4500-\mathrm{KMnO}_{4}$ \\
\hline Manganês Total & 3111 - B \\
\hline \hline
\end{tabular}

Fonte: AWWA (2005) 


\subsection{2 - Contagem e Identificação do Fitoplancton}

A contagem do fitoplancton foi feita com o método das câmaras de sedimentação (UTHERMÖHL, 1958) e a densidade foi calculada segundo APHA (1999), sendo a unidade fundamental de contagem o campo do microscópio.

\subsection{3 - Clorofila-a}

Para a determinação da concentração da clorofila-a, as amostras foram filtradas em membranas de microfibra de vidro (Milipore AP 20; $47 \mathrm{~mm}$ de diâmetro e 0,8 - 8,0 $\mu \mathrm{m}$ de porosidade), conservadas no freezer até o momento da extração. No laboratório, a extração foi feita com etanol $80 \%$.

A análise dos extratos em espectrofotometria seguiu a metodologia descrita em APHA (1999) e a leitura foi realizada nos comprimentos de ondas $665 \mathrm{~nm}$ e $750 \mathrm{~nm}$.

Para a determinação da clorofila-a foi utilizada a equação descrita por NUSH (1980):

Clorofila-a $=27,9 \cdot\left[\left(\mathrm{Eu}_{665}-\mathrm{Eu}_{750}\right)-\left(\mathrm{Ea}_{665}-\mathrm{Ea}_{750}\right)\right] \cdot[\mathrm{v} /(\mathrm{V} . \mathrm{s})]$

Onde:

- Eu é a absorbância da amostra não acidificada;

- Ea é a absorbância da amostra acidificada;

- v é o volume de estrato $(\mathrm{mL})$;

- V é o volume de amostra filtrada $(\mathrm{mL})$;

- s é a espessura da cubeta $(\mathrm{cm})$;

- 27,9 é o coeficiente de absorção específica da clorofila-a;

Foi adotada razão de rendimento da clorofila-a não acidificada para a acidificada igual a 1,7 . 


\subsection{4 - Microcistina Extracelular}

A determinação da concentração de microcistina livre no meio líquido (extracelular), foi feita pelo método de ELISA, através da utilização de kits de placas fornecidos pela SOVEREIGN do Brasil. Detalhes relativos à esse método são apresentados no item 3.3.4.

O kit utilizado é composto por uma placa com 96 cavidades recobertas com anticorpos padrões de microcistina, que tem capacidade para análise de até 46 amostras em duplicata. $\mathrm{O}$ armazenamento do kit foi feito em geladeira a cerca de 4 ${ }^{\circ} \mathrm{C}$, condição que garante validade de 12 meses desse material, conforme informações do fornecedor.

A leitura de cor de cada cavidade foi feita com leitora universal, marca Biotek Instruments Inc., modelo ELX 800 através de espectrofotometria.

A faixa de detecção do kit de placa é de $0,16 \mu \mathrm{g} \cdot \mathrm{L}^{-1}$ a $2,50 \mu \mathrm{g} \cdot \mathrm{L}^{-1}$, portanto, para a medição de concentrações superiores de microcistina, foi necessária prévia diluição das amostras para que a concentração de microcistina ficasse dentro da faixa de medição do kit empregado. Devido às diferentes concentrações de microcistina previstas em cada tipo de amostra (água de estudo, flotada, oxidada etc), as razões de diluição foram previamente estabelecidas com base na sensibilidade adquirida ao longo dos ensaios realizados. 


\section{5 - RESULTADOS E DISCUSSÃO}

\section{1 - Congelamento e Descongelamento de Amostras para a Avaliação da Concentração de Microcistina Total}

Neste item são apresentados os resultados obtidos nos ensaios de congelamento e descongelamento das amostras e a avaliação da lise celular obtida em cada condição de ensaio e conseqüente liberação de microcistina para o meio líquido.

Conforme citado anteriormente no item 4.4.1, foram definidos diferentes ciclos de congelamento e descongelamento de amostras da cultura com predominância de Microcystis sp cultivada no laboratório. O efeito de cada ciclo pode ser observado na tabela 5.1 e nas figuras 5.1 e 5.2 .

Tabela 5.1 - Contagem de Fitoplancton, Eficiência de Lise Celular e Concentração de Microcistina

\begin{tabular}{|c|c|c|c|}
\hline Amostra & $\begin{array}{l}\text { Contagem de } \\
\text { Fitoplancton } \\
\left(\text { células.mL } L^{-1}\right)\end{array}$ & $\begin{array}{l}\text { Redução do } \\
\text { Número de Células } \\
(\%)\end{array}$ & $\begin{array}{c}\text { Concentração de } \\
\text { Microscistina } \\
\left(\mu g . L^{-1}\right)\end{array}$ \\
\hline Cultura não lisada & $9,67 \times 10^{6}$ & & 176 \\
\hline \multicolumn{4}{|l|}{ Cultura com 1 ciclo } \\
\hline Cong/descong. & $1,52 \times 10^{7}(*)$ & $-57,60$ & 617 \\
\hline Cultura 2 ciclos Cong/descong. & $1,51 \times 10^{5}$ & 98,44 & 653 \\
\hline Cultura 3 ciclos Cong/descong. & $1,72 \times 10^{5}$ & 98,22 & 639 \\
\hline Cultura 4 ciclos Cong/descong. & $4,08 \times 10^{3}$ & 99,96 & 700 \\
\hline
\end{tabular}

$\overline{(*) \text { - Resultado desconsiderado para a presente análise, por resultar numa eficiência de redução de }}$ células íntegras negativa e, portanto, inviável de ocorrência na prática. 


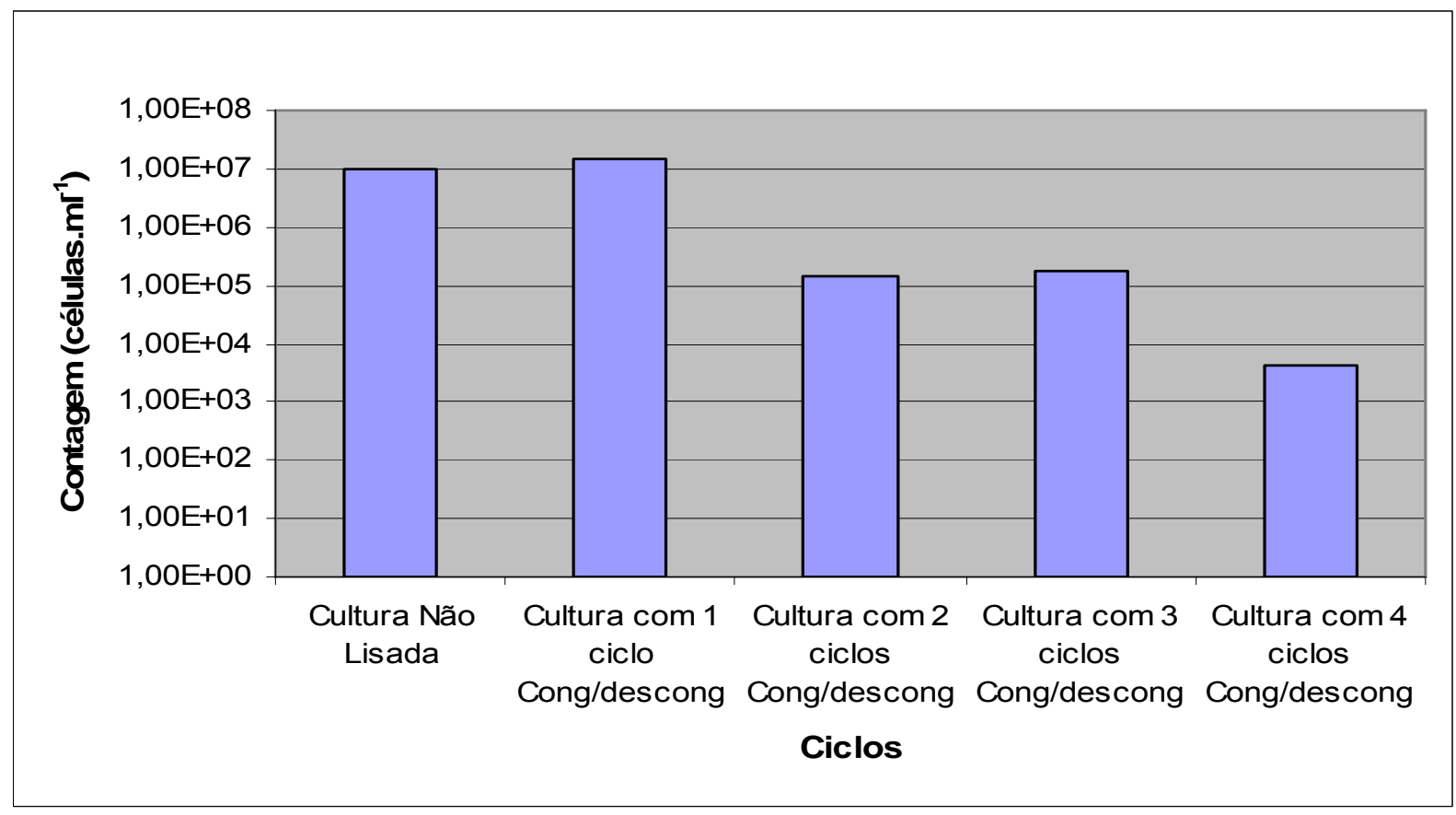

Figura 5.1 - Relação entre o número de ciclos de congelamento e descongelamento da amostra e a contagem de células íntegras remanescentes

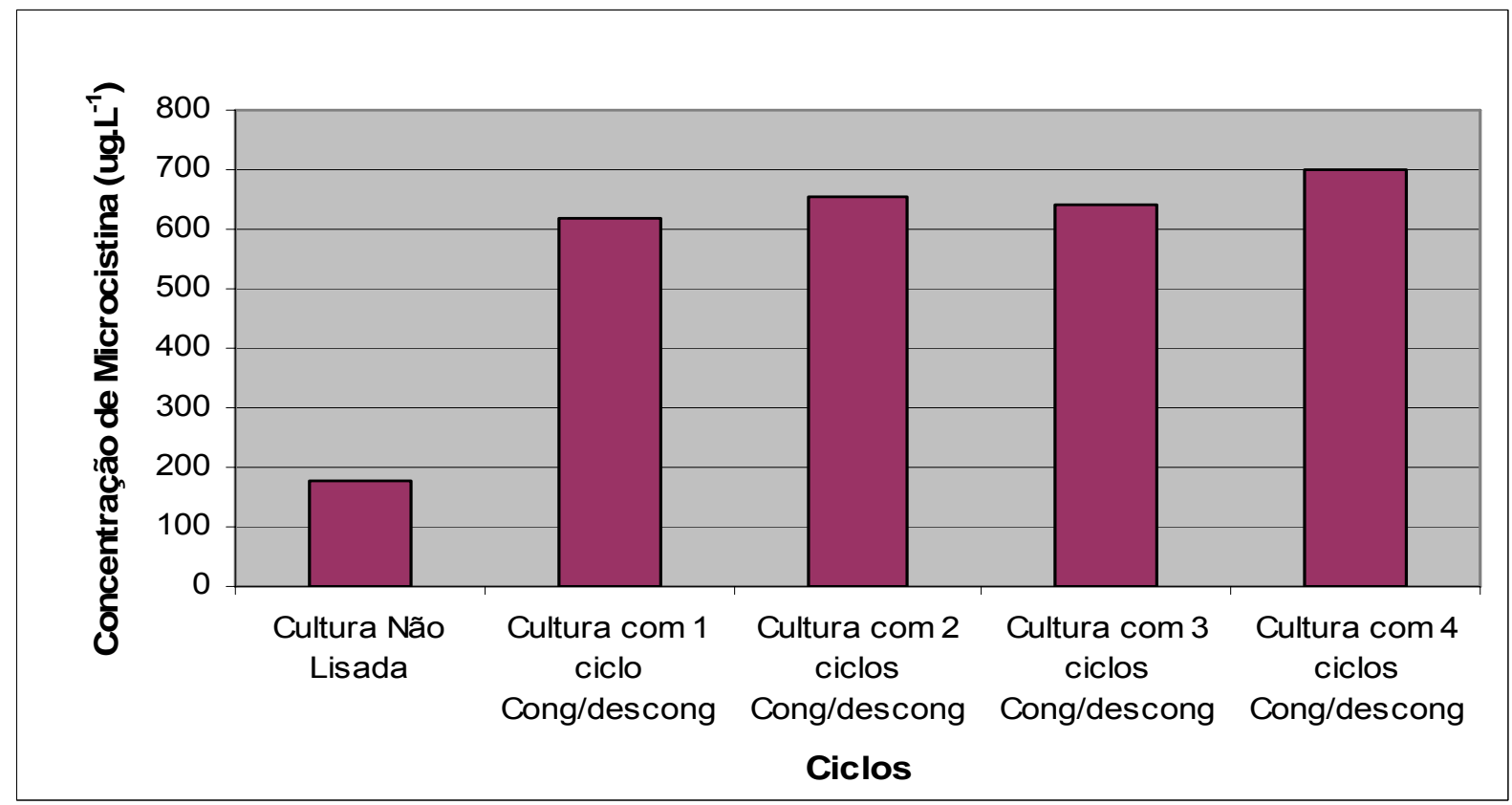

Figura 5.2 - Relação entre o número de ciclos de congelamento e descongelamento da amostra e a concentração de microcistina dissolvida no meio líquido. 
Através da tabela 5.1 e da figura 5.1 observa-se que o número de células íntegras identificadas na contagem de fitoplancton sofre redução bastante significativa quando a amostra é submetida aos ciclos de congelamento e descongelamento, o que indica que a lise celular foi efetiva e tendeu a apresentar-se mais eficiente com o aumento do número de ciclos de congelamento e descongelamento.

Da mesma forma, mediante os resultados apresentados na tabela 5.1 e da figura 5.2 observa-se que os efeitos da lise celular se manifestaram com o congelamento e descongelamento da amostra através do aumento bastante significativo da concentração de microcistina livre no meio líquido (microcistina extracelular) já no primeiro ciclo de congelamento e descongelamento, quando a concentração original da cultura, de cerca de $176 \mu \mathrm{g} \cdot \mathrm{L}^{-1}$, passou para mais de $600 \mu \mathrm{g} \cdot \mathrm{L}^{-1}$, ou seja, um aumento de mais de 3 vezes o valor original.

Após o primeiro ciclo observa-se tendência de crescimento, ainda que modesto, da concentração de microcistina (concentração após 4 ciclos de cerca de $700 \mu \mathrm{g} \cdot \mathrm{L}^{-1}$, comparada à concentração da amostra submetida a um ciclo, de $617 \mu \mathrm{g} \cdot \mathrm{L}^{-1}$ ), bem como decaimento do número de células íntegras identificadas na contagem de fitoplancton, indicando que a prática de adoção de apenas um ciclo de congelamento, embora seja efetiva para a lise celular e liberação de toxina, pode ser melhorada com a adoção de mais ciclos de forma a extrair uma quantidade maior de toxina contida originalmente nas células de Microcystis sp (microcistina Intracelular).

Portanto, visando a avaliação aproximada da quantidade de microcistina total (intracelular e extracelular) nos ensaios de oxidação descritos nos itens 4.4 .3 a 4.4.6, para determinadas amostras de água de estudo e submetidas a diferentes 
condições de ensaio, foi adotado o procedimento de submeter essas amostras a quatro ciclos de congelamento e descongelamento.

Finalmente, é fundamental observar que, embora tenha sido obtida lise celular superior a 99,9 \% e tenha ocorrido um aumento bastante significativo de microcistina (cerca de 4 vezes a concentração original da cultura) nas amostras submetidas a 4 ciclos de congelamento e descongelamento, a medição de microcistina decorrente das amostras processadas dessa maneira certamente não representa a quantidade "total" de toxina presente, pois ainda existe uma parcela de microcistina que deve estar ainda contida no interior das células não lisadas ou aderida ao material celular disperso pelo meio líquido.

Entretanto, presume-se que a microcistina retida no material celular disperso decorrente da lise ou nas células íntegras remanescentes é pouco significativa frente à grande concentração que foi medida e, dessa forma, a amostra pode ser considerada representativa da concentração potencial de microcistina em uma determinada amostra, passível de determinação pelo método ELISA tendo em vista a microcistina estar dissolvida no meio líquido.

\section{2 - Pós Oxidação com Cloro}

5.2.1 - ETAPA I - Investigação das Condições de Coagulação da Água de Estudo e Determinação da Curva de Residual de Cloro na Água Filtrada

Nesta ETAPA I foi usada a Água de Estudo 1 que apresenta as seguintes características qualitativas destacadas na tabela 5.2. 
Tabela 5.2 - Características Qualitativas de Água de Estudo 1

\begin{tabular}{ccc}
\hline \hline Parâmetro & Valor & Unidade \\
\hline \hline Cor aparente & 660 & $\mathrm{uH}$ \\
\hline Turbidez & 64 & $\mathrm{uT}$ \\
\hline $\mathrm{pH}$ & 6,93 & - \\
\hline Absorbância a 254 nm $\left(^{*}\right)$ & 0,18 & - \\
\hline Alcalinidade total & 47 & $\mathrm{mgCaCO}_{3} \cdot \mathrm{L}^{-1}$ \\
\hline Microcistina & 15,0 & $\mu \mathrm{Hg}^{-1}$ \\
\hline \hline
\end{tabular}

$(*)$ - Comprimento do caminho óptico igual a $1,0 \mathrm{~cm}$.

Após a realização de 11 ensaios de coagulação, floculação e flotação da água de estudo, seguindo o mesmo método, foram observadas boas condições de tratabilidade com uma dosagem de cloreto férrico de $76 \mathrm{mg} \cdot \mathrm{L}^{-1}$ e $\mathrm{pH}$ de coagulação, decorrente dessa dosagem, de 5,95. Para essas condições de tratabilidade foram obtidos valores de cor aparente e turbidez respectivamente iguais a 7,0 uH e 0,61 uT, que correspondem a eficiências de remoção de cor e turbidez de aproximadamente $99 \%$.

Com a melhor condição de tratabilidade (dosagem de cloreto férrico de $76 \mathrm{mg} \cdot \mathrm{L}^{-1} \mathrm{e}$ sem adição de ácido ou álcali) foram feitos 24 ensaios de coagulação, floculação e flotação que resultaram na produção de 23 litros de água submetida à flotação e, posteriormente, filtrada em papel Whatmam 40 para ser utilizada nos ensaios de oxidação subsequentes. A qualidade das águas flotada e filtrada produzidas é apresentada na tabela 5.3 . 
Tabela 5.3 - Características Qualitativas das Águas Flotada e Filtrada Produzidas

\begin{tabular}{cccc}
\hline \hline Parâmetro & \multicolumn{2}{c}{ Valores } & Unidade \\
\cline { 2 - 3 } & A Flot & A Filt & \\
\hline \hline Cor aparente & 7 & 6 & $\mathrm{uH}$ \\
\hline Turbidez & 0,61 & 0,45 & $\mathrm{uT}$ \\
\hline $\mathrm{pH}$ & 7,47 & 7,43 & - \\
\hline Absorbância 254 nm $\left(^{*}\right)$ & 0,06 & 0,05 & - \\
\hline Alcalinidade & 24 & --- & $\mathrm{mgCaCO}_{3} \cdot \mathrm{L}^{-1}$ \\
\hline \hline
\end{tabular}

ND - Não detectado (abaixo do limite de detecção do método)

(*) - Comprimento do caminho óptico igual a 1,0 cm.

Finalizando essa primeira etapa de ensaios foi determinada a curva de residual de cloro na água filtrada para um tempo de contato de oxidação de 30 minutos, conforme é apresentado na tabela 5.4 e na figura 5.3 .

Tabela 5.4 - Concentrações de Cloro Livre Residual na Água Filtrada, com pH = 7,43

\begin{tabular}{|c|c|}
\hline $\begin{array}{l}\text { Dosagem de Cloro Ativo } \\
\qquad\left(\mathrm{mgCl}_{2} \cdot \mathrm{L}^{-1}\right)\end{array}$ & $\begin{array}{l}\text { Cloro Livre Residual } \\
\qquad\left(\mathrm{mgCl}_{2} \cdot \mathrm{L}^{-\mathbf{1}}\right)\end{array}$ \\
\hline 1,0 & 0,15 \\
\hline 2,0 & 0,71 \\
\hline 4,0 & 2,59 \\
\hline 6,0 & 4,70 \\
\hline 8,0 & 6,12 \\
\hline 10,0 & 7,88 \\
\hline
\end{tabular}




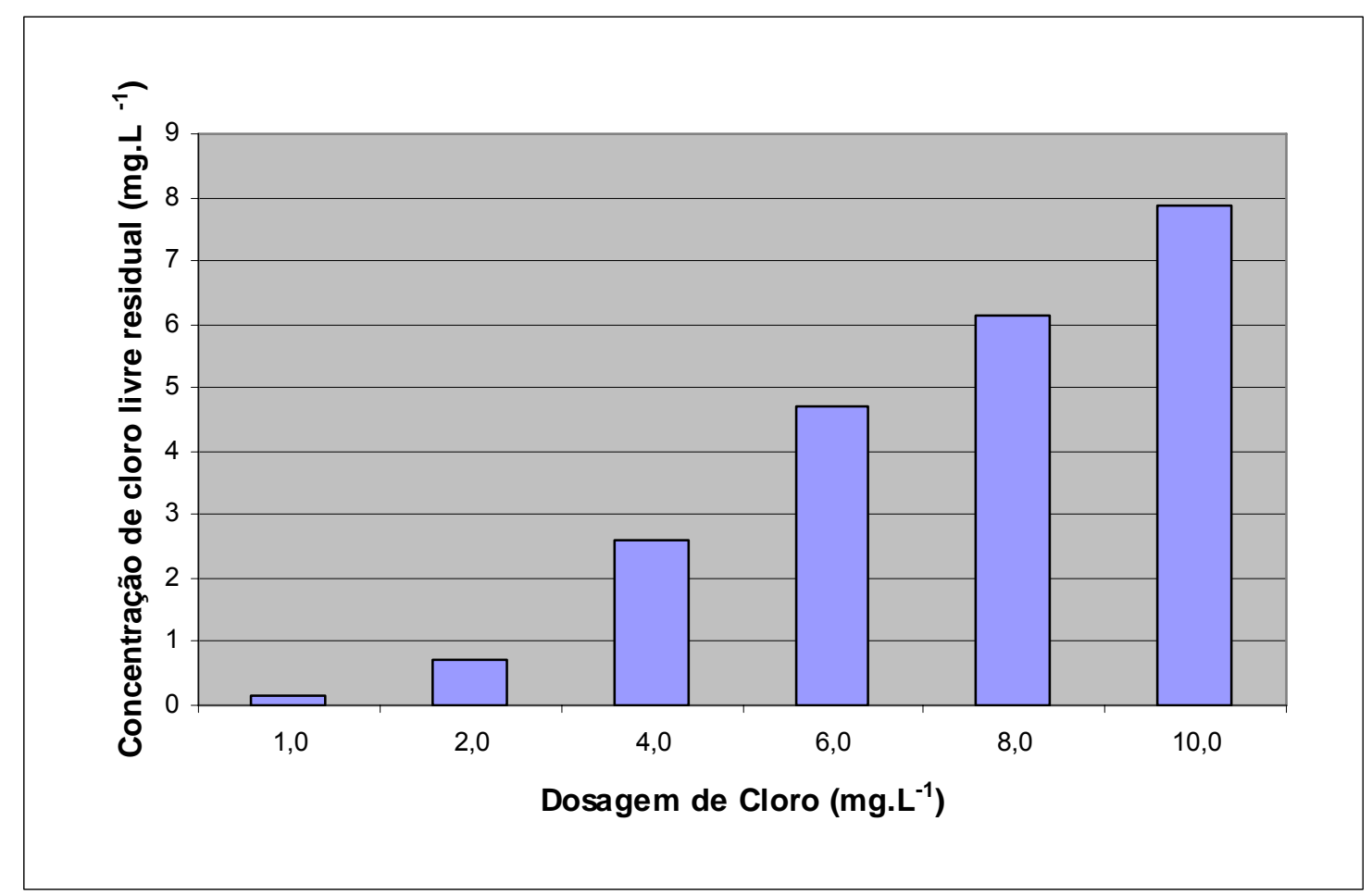

Figura 5.3 - Residual de Cloro na Água Filtrada para tempo de contato de 30 minutos.

Na curva de residual de cloro na água de estudo determinada no trabalho de pesquisa citado no item 3.6.4 (BUENO, 2005), foi observado que para as dosagens mais baixas de cloro houve a formação inicial de cloro combinado e sua posterior eliminação até uma concentração mínima que define o "breakpoint", sendo que, somente após esse ponto foi observada a formação de residual de cloro livre para dosagens de oxidante superiores a 5,0 mg. $\mathrm{L}^{-1}$.

No caso da água filtrada não foi observado o breakpoint, indicando que o cloro residual formado é livre desde as dosagens mais baixas de cloro ativo, devido a indisponibilidade de nitrogênio amoniacal para a formação de cloraminas.

Portanto, os resultados encontrados nas duas águas são coerentes tendo em vista suas características qualitativas, principalmente com relação às concentrações de 
nitrogênio amoniacal presentes em cada etapa do tratamento e, consequentemente, o potencial de formação de cloro combinado, bem como a presença de matéria orgânica que incide na demanda de cloro livre e combinado.

5.2.2 - ETAPA II - Investigação a Influência da Pós-oxidação com Cloro na Remoção da Microcistina

Nesta etapa foram realizados os ensaios de oxidação da água filtrada produzida na etapa anterior, sendo que os resultados são apresentados na tabela 5.5 e figuras 5.4 e 5.5 .

Tabela 5.5 - Resultados dos Ensaios de Oxidação da Água Filtrada, com Cloro. Concentração de microcistina extracelular na água de estudo de $15 \mu \mathrm{gg.L}{ }^{-1}$ e pH de 6,93.

\begin{tabular}{|c|c|c|c|c|c|c|}
\hline \multirow{3}{*}{$\begin{array}{c}\text { Dosagem } \\
\text { cloro } \\
\left(\mathrm{mgCl}_{2} \cdot \mathrm{L}^{-1}\right)\end{array}$} & \multirow{2}{*}{\multicolumn{3}{|c|}{$\begin{array}{c}\begin{array}{c}\text { Residual de cloro } \\
\left(\mathrm{mgCl}_{2} \cdot \mathrm{L}^{-1}\right)\end{array} \\
\text { Tempo de Contato } \\
(\mathrm{min})\end{array}$}} & \multirow{2}{*}{\multicolumn{3}{|c|}{$\begin{array}{c}\begin{array}{c}\text { Concentração remanescente de } \\
\text { microcistina }\left(\mu g . L^{-1}\right)\end{array} \\
\text { Tempo de Contato } \\
(\mathrm{min})\end{array}$}} \\
\hline & & & & & & \\
\hline & 15 & 30 & 60 & 15 & 30 & 60 \\
\hline 1,0 & 0,30 & 0,21 & 0,11 & 1,3 & 1,1 & 1,0 \\
\hline 3,0 & 1,80 & 1,68 & 1,52 & 0,9 & 0,8 & 0,7 \\
\hline 5,0 & 3,57 & 3,37 & 3,23 & 0,7 & 0,6 & 0,6 \\
\hline 7,0 & 5,44 & 5,08 & 5,04 & 0,6 & 0,5 & 0,6 \\
\hline
\end{tabular}




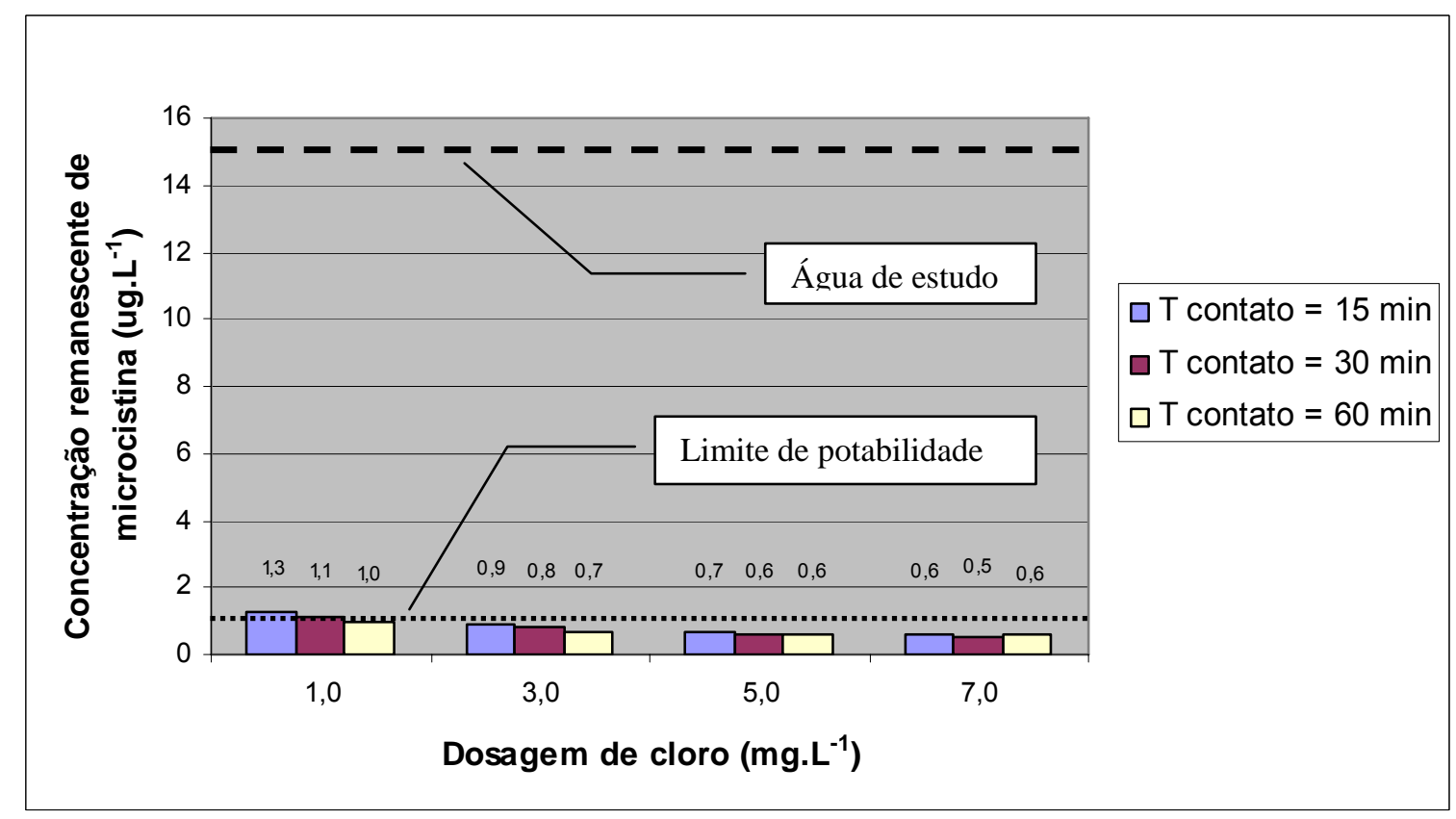

Figura 5.4 - Concentrações Remanescentes de Microcistina após a Oxidação da água filtrada com cloro

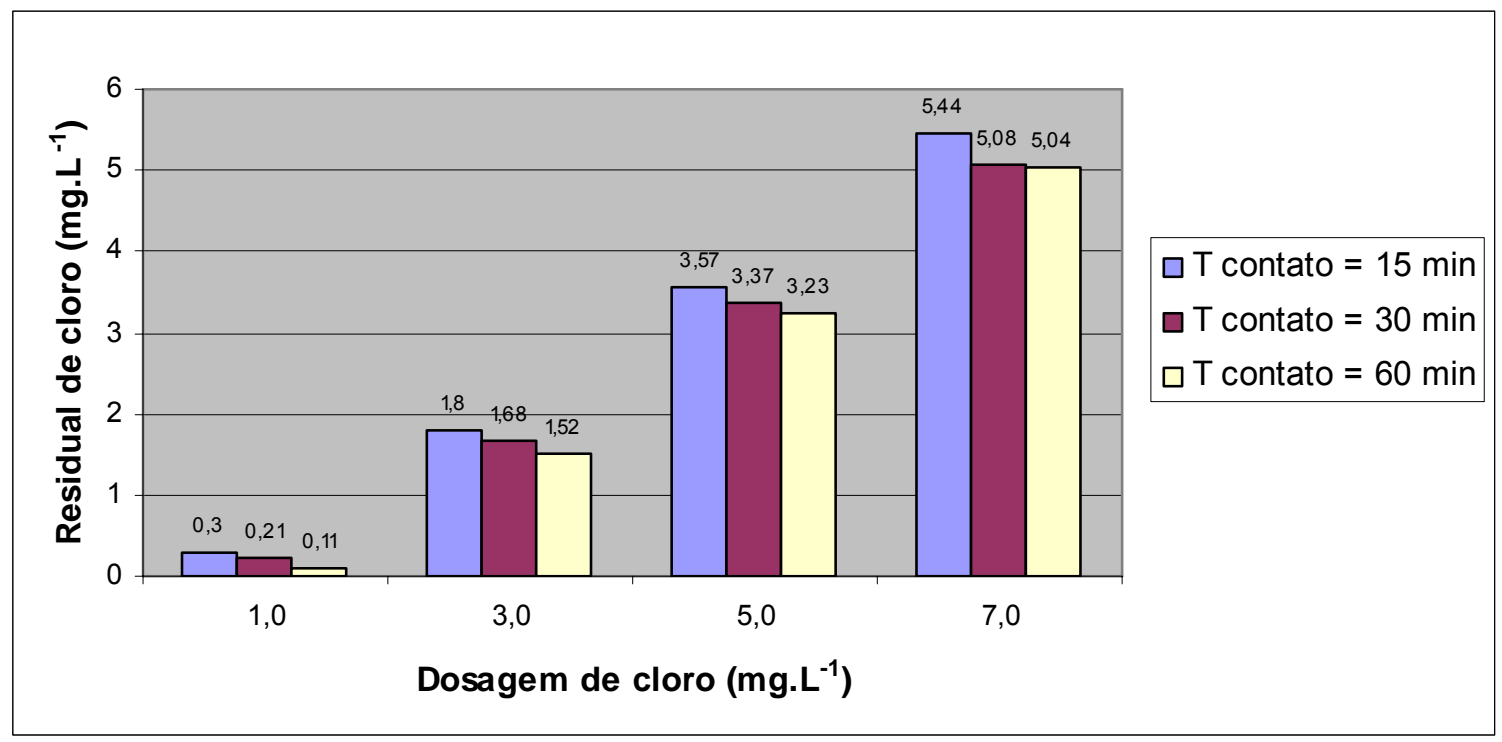

Figura 5.5 - Residuais de Cloro na Água Filtrada após a Oxidação

Em vista dos resultados obtidos, observa-se que a partir da dosagem de $3,0 \mathrm{mg} \cdot \mathrm{L}^{-1}$ de cloro ativo na água filtrada, o padrão de potabilidade com relação à microcistina 
foi atendido (valores $<1,0 \mu \mathrm{g} \cdot \mathrm{L}^{-1}$ ) para tempos de contato de oxidação de 30 e 60 minutos. Isso caracteriza uma eficiência de remoção de microcistina superior a 94\% tendo como base a concentração inicial de 15,0 $\mu \mathrm{g} \cdot \mathrm{L}^{-1}$ na água de estudo. Também foi observada uma leve tendência de aumento de eficiência relacionada com o aumento do tempo de contato para a oxidação.

Com relação aos residuais de cloro, observa-se que os valores encontrados estão coerentes com a curva de residual determinada na etapa anterior, sendo influenciados pelo tempo de contato de oxidação. Coerentemente, com o aumento do tempo de contato ocorreu maior consumo de cloro, resultando em menores concentrações residuais.

5.2.3 - ETAPA III - Investigação da Influência da Variação do pH na Pós-oxidação com Cloro visando a Remoção da Microcistina

Como citado anteriormente no capítulo 4, essa etapa foi realizada com outra água de estudo, a Água de Estudo 2 também usada para os ensaios de investigação da inter-oxidação com o permanganato de potássio cujos resultados e condições de tratabilidade são apresentados e comentados no item 5.3. Observa-se somente que a melhor condição de tratabilidade ocorreu com dosagem de cloreto férrico de 65,0 $\mathrm{mg} \cdot \mathrm{L}^{-1}$ e $\mathrm{pH}$ de 6,65 , resultando em uma água submetida à flotação com cor aparente e turbidez respectivamente iguais a $11 \mathrm{uH}$ e $0,11 \mathrm{uT}$, que representam uma eficiência de remoção superior a 98 \% em relação a essas variáveis de controle.

Para essa condição de tratabilidade foram produzidos 16 litros de água submetida à flotação em 16 ensaios de coagulação, floculação e flotação, que foi posteriormente filtrada a vácuo em papel Whatmam 40 para a realização dos ensaios de oxidação 
com cloro e com permanganatdo de potássio (pertencentes ao outro grupo de ensaios - item 5.3).

Os ensaios de oxidação com cloro, visando a avaliação da influência do pH na eficiência de remoção de microcistina, foram então realizados considerando-se a dosagem de cloro ativo de $7,0 \mathrm{mg} \cdot \mathrm{L}^{-1}$ e o tempo de contato de oxidação de 30 minutos, obtidos no ensaio de oxidação anterior relativo ao item 5.4.2. Embora outras condições de dosagem e tempos de contato tenham sido efetivas no atendimento dos padrões de potabilidade de microcistina, esses valores foram adotados devido aos seguintes motivos:

- a dosagem de 7,0 mg. $\mathrm{L}^{-1}$ ter resultado no melhor desempenho de remoção de microcistina, embora as concentrações residuais de cloro livre tenham ficado acima dos limites recomendados no padrão de potabilidade;

- o tempo de contato de 30 minutos ser o valor recomendado pela Norma ABNT para o dimensionamento de câmaras de contato em sistemas de tratamento de água em escala real.

Embora tenham sido obtios bons resultados em termos de remoção de microcistina para dosagens menores de cloro e a elevada dosagem adotada para a sequência dos ensaios tenha resultado em concentrações residuais acima do limite definido na Portaria 518 de 25/03/2004, a avaliação da condição de dosagem de $7,0 \mathrm{mg} \cdot \mathrm{L}^{-1}$ foi muito importante para a avaliação do potencial de formação de trihalometanos nos ensaios complementares apresentados no item 5.6.

Na tabela 5.6 e nas figuras 5.6 e 5.7 são apresentados os resultados obtidos nesta etapa de ensaios. 
Tabela 5.6 - Influência da variação do pH na pós-oxidação da água filtrada com cloro. Concentração de microcistina na água de estudo de $15,7 \mu g . \mathrm{L}^{-1}$.

\begin{tabular}{|c|c|c|c|c|}
\hline $\begin{array}{l}\text { Dosagem } \\
\text { Cloro } \\
\left(\mathrm{mgCl}_{2} \cdot \mathrm{L}^{-1}\right)\end{array}$ & $\begin{array}{l}\text { Tempo de } \\
\text { Contato } \\
\text { (min) }\end{array}$ & pH & $\begin{array}{l}\text { Residual de } \\
\text { Cloro } \\
\left(\mathrm{mgCl}_{2} \cdot \mathrm{L}^{-1}\right)\end{array}$ & $\begin{array}{c}\text { Concentração de } \\
\text { Microcistina na Água } \\
\text { Oxidada } \\
\left(\mu \text { g.L }^{-1}\right) \\
\end{array}$ \\
\hline 7,0 & 30 & 4,61 & 5,16 & 0,4 \\
\hline 7,0 & 30 & 5,85 & 5,20 & 0,4 \\
\hline 7,0 & 30 & 7,48 & 5,32 & 0,4 \\
\hline 7,0 & 30 & 8,92 & 5,56 & 2,3 \\
\hline 7,0 & 30 & 10,00 & 5,60 & 5,2 \\
\hline
\end{tabular}

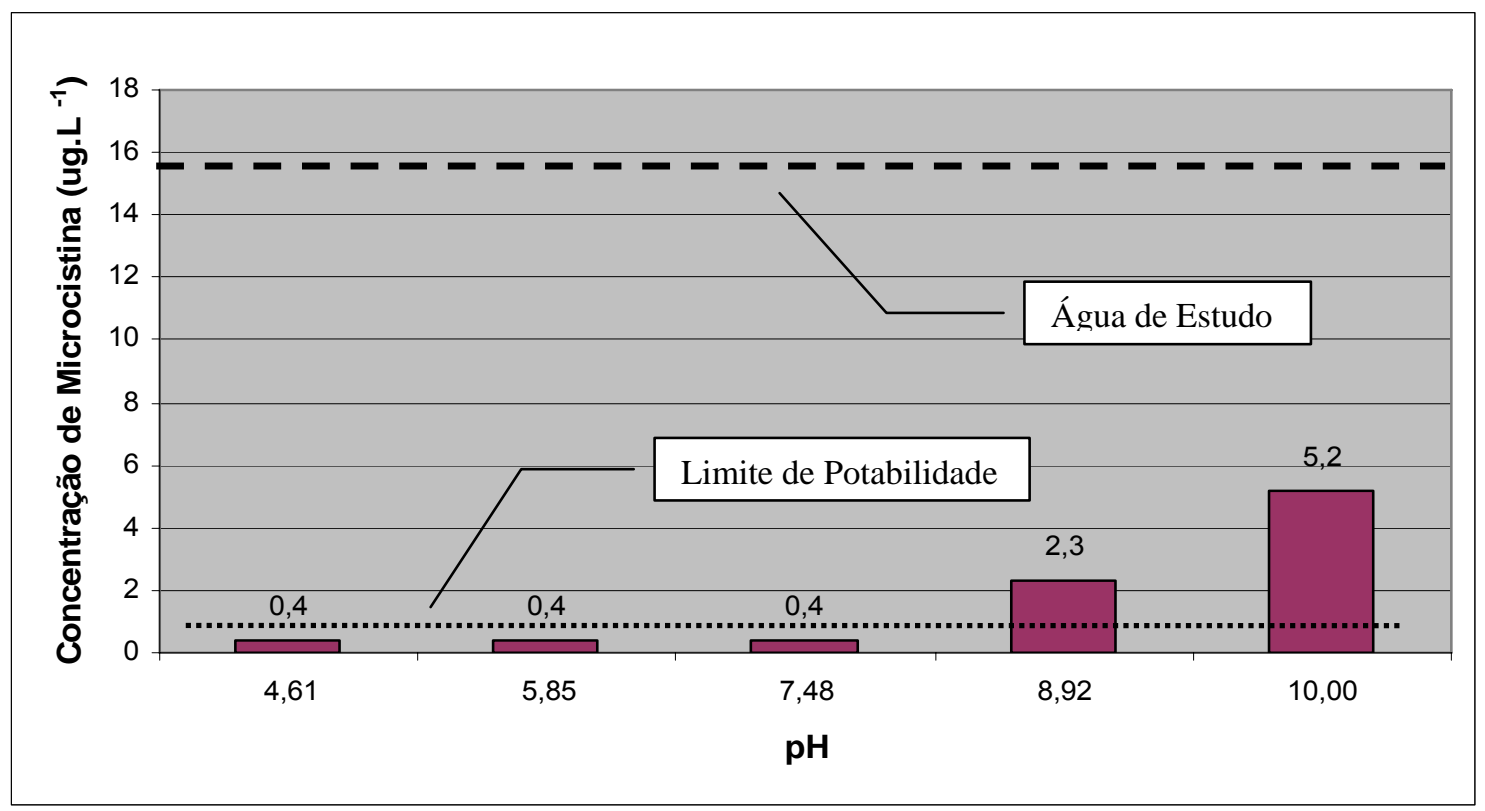

Figura 5.6 - Concentrações Remanescentes de Microcistina após a Oxidação da água

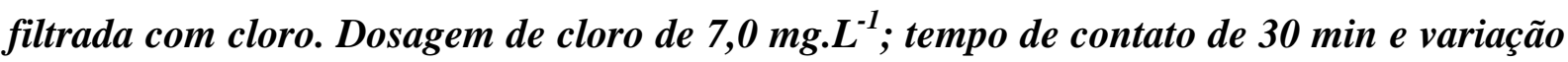
de $\mathrm{pH}$ 


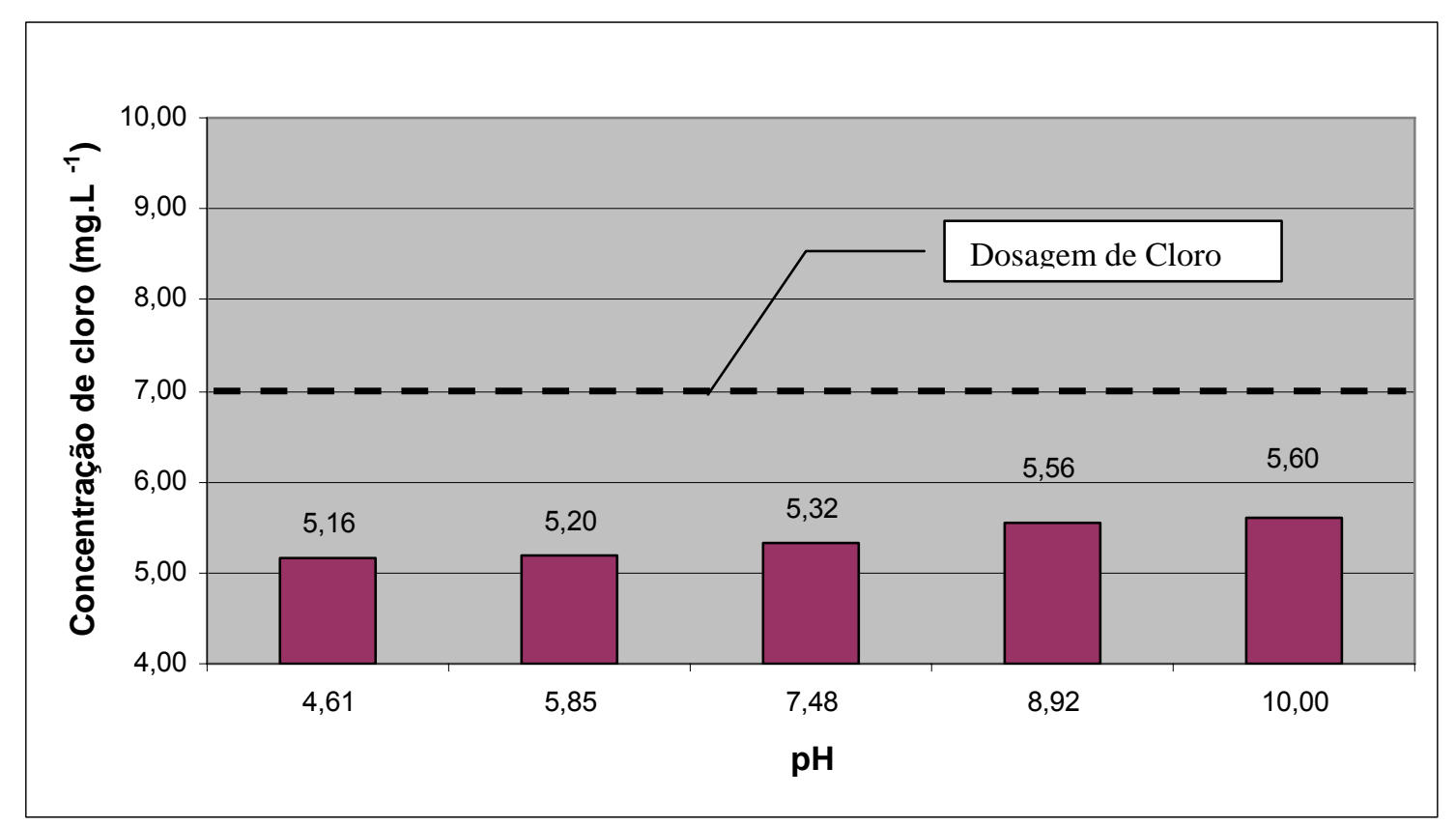

Figura 5.7 - Residuais de Cloro na Água Filtrada. Dosagem de cloro de 7,0 mg. ${ }^{-1}$, tempo de contato de 30 minutos e variação de $\mathrm{pH}$

Observa-se que o $\mathrm{pH}$ influenciou de forma significativa o desempenho da oxidação da água filtrada para a remoção da microcistina, sendo que a redução do $\mathrm{pH}$ contribuiu para a melhora do processo oxidativo. Embora a dosagem de cloro adotada para esses ensaios tenha sido muito elevada, resultando em concentração residual de cloro na água filtrada muito acima do padrão de potabilidade, concentrações remanescentes de microcistina abaixo de $1,0 \mu \mathrm{g} \cdot \mathrm{L}^{-1}$ somente foram obtidas com valores de $\mathrm{pH}$ inferiores a 7,5, quando a eficiência em termos de remoção de microcistina superou o patamar de $97 \%$, tendo como base uma concentração inicial de microcistina na água de estudo de $15,7 \mu \mathrm{g} \cdot \mathrm{L}^{-1}$.

A influência do pH também foi observada nas concentrações residuais de cloro, pois para uma mesma dosagem inicial de $7,0 \mathrm{mg} \cdot \mathrm{L}^{-1}$ foi observada leve tendência de elevação da concentração residual de cloro com a elevação dos valores de pH. Esse 
comportamento apresenta indícios de que a melhoria do processo oxidativo, causada pela queda do $\mathrm{pH}$ pode ser traduzida por um aumento do consumo de cloro e, portanto, a redução de suas concentrações residuais para uma mesma dosagem inicial.

5.2.4 - Considerações Referentes ao Comportamento Global da Remoção da Microcistina nos Diferentes Estágios do Fluxograma de Tratamento

Considerando as concentrações de microcistina na forma extracelular (livre no meio líquido) e total (extracelular e intracelular), que são representadas de forma aproximada pelas amostras submetidas aos ciclos de congelamento e descongelamento, as tabelas 5.7 e 5.8 , bem como as figuras 5.8 e 5.9 apresentam os resultados dos ensaios de pós-oxidação com cloro.

Tabela 5.7 - Concentrações de Microcistina Intracular e Extracelular nos Ensaios de Pós-oxidação com Cloro.

\begin{tabular}{|c|c|c|c|}
\hline \multirow{2}{*}{ Amostra } & \multicolumn{3}{|c|}{ Concentração de Microcistina $\left(\mu g . L^{-1}\right)$} \\
\hline & Total & Intracelular (*) & Extracelular \\
\hline Água de Barra Bonita & 3,1 & 2,7 & 0,4 \\
\hline Cultura & 2721,0 & 2626,0 & 95,0 \\
\hline Água de Estudo & 274,0 & 259,0 & 15,0 \\
\hline Água submetida à flotação & 4,5 & 2,0 & 2,6 \\
\hline Água Filtrada & 3,7 & 1,3 & 2,5 \\
\hline Água Oxidada c/ Cloro $(\mathrm{pH}=7,48)$ & -- & -- & 0,4 \\
\hline
\end{tabular}

$\left({ }^{*}\right)$ - Diferença entre as concentrações de microcistina total e microcistina extracelular. 
Tabela 5.8 - Eficiências de Remoção de Microcistina Total e Extracelular nas Diversas Etapas do Fluxograma de Tratamento da Condição de Pós-oxidação com Cloro

\begin{tabular}{ccc}
\hline \hline Etapa do Tratamento & \multicolumn{2}{c}{ Eficiências Acumuladas de Remoção (\%) } \\
\cline { 2 - 3 } & $\begin{array}{c}\text { Base - Microcistina } \\
\text { Total }\end{array}$ & $\begin{array}{c}\text { Base - Parcela } \\
\text { Extracelular }\end{array}$ \\
\hline \hline Flotação & 98,4 & 83,0 \\
\hline Filtração & 98,6 & 83,7 \\
\hline Pós-Oxidação c/ Cloro $(\mathrm{pH}=7,48)$ & - & 97,7 \\
\hline \hline
\end{tabular}

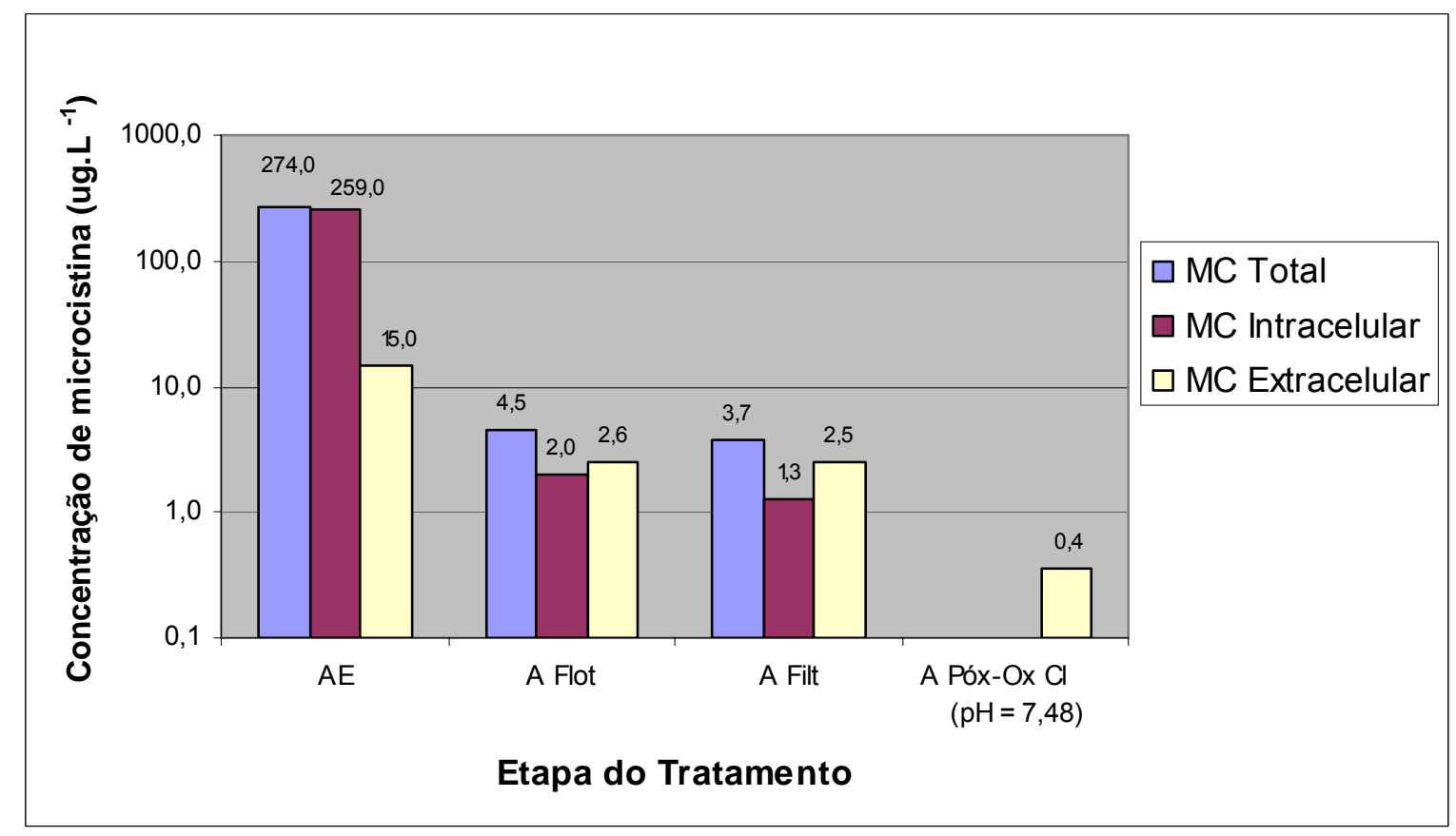

Figura 5.8 - Concentrações Remanescentes de Microcistina ao Longo do Fluxograma de Tratamento 


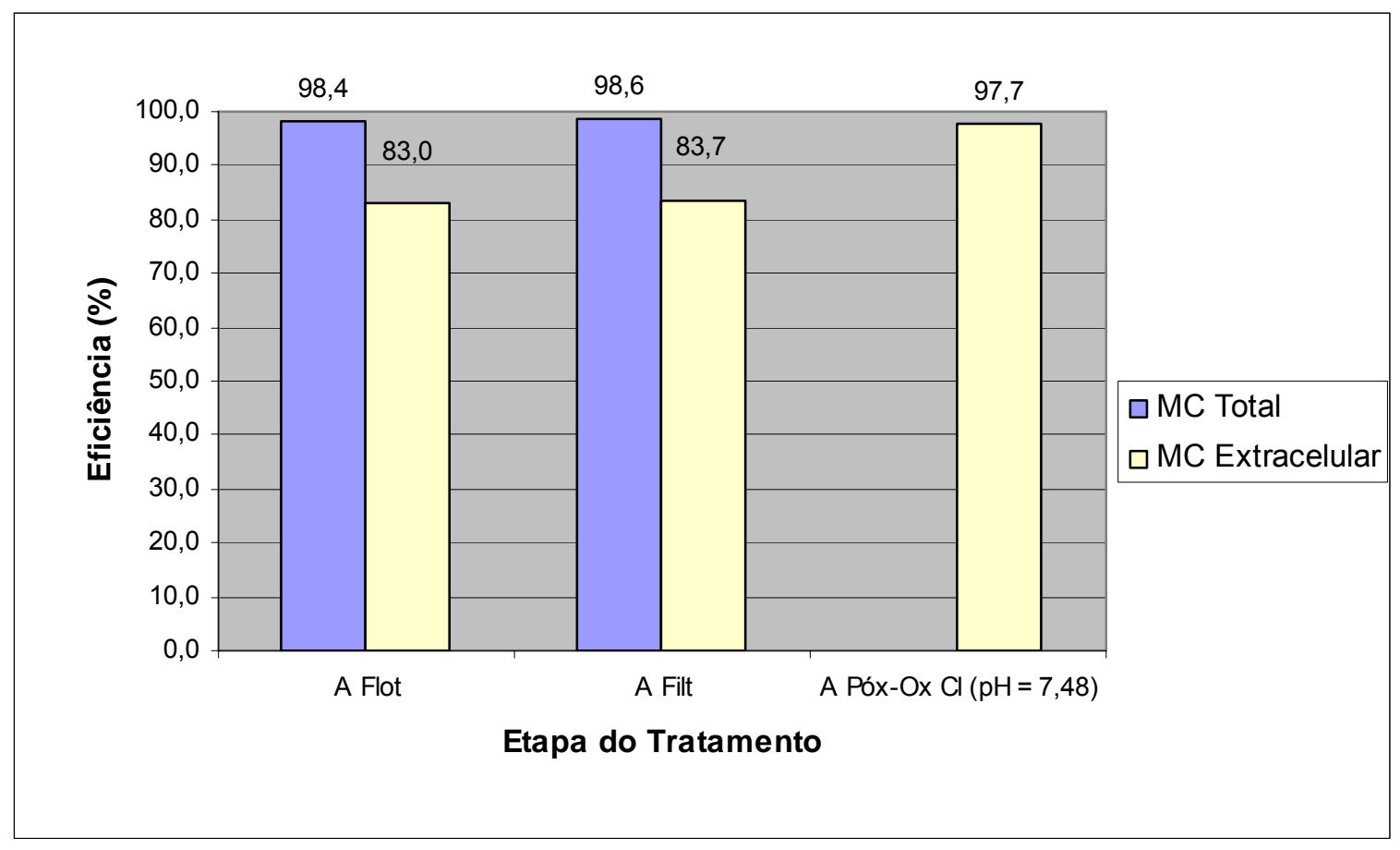

Figura 5.9 - Eficiências de remoção de Microcistina ao Longo do Fluxograma de Tratamento

Comparando-se as concentrações aproximadas de microcistina total com as concentrações de microcistina extracelular, observa-se que existe grande diferença entre esses dois valores nas amostras de cultura e de água de estudo. Considerando que as referidas amostras apresentam grande quantidade de fitoplancton, com forte predominância de Microcystis $s p$ devido às características da cultura, pode ser assumido com segurança que a diferença é representativa da parcela que originalmente estava contida no interior das células antes do congelamento, denominada "intracelular". Confirmando o que foi observado nos ensaios de desenvolvimento da técnica de congelamento e descongelamento de amostras abordados nos itens 4.4.1 e 5.1.

Portanto, a técnica de lise celular estabelecida a partir desta fase do estudo evidenciou que o maior potencial de toxicidade da cultura e da água de estudo 
reside na parcela de toxina intracelular. Para a cultura foi observada concentração de microcistina intracelular cerca de 28 vezes superior à parcela de toxina extracelular (2626 $\mu \mathrm{g} \cdot \mathrm{L}^{-1}$ contra $\left.95 \mu \mathrm{g} \cdot \mathrm{L}^{-1}\right)$, enquanto que no caso da água de estudo a parcela de toxina intracelular é cerca de 17 vezes superior à parcela extracelular $\left(259 \mu \mathrm{g} \cdot \mathrm{L}^{-1}\right.$ contra $\left.15 \mu \mathrm{g} \cdot \mathrm{L}^{-1}\right)$.

Considerando a microcistina total (soma das parcelas intracelular e extracelular), observa-se que em termos de desempenho de remoção, a etapa de flotação apresenta grande eficiência (superior a $98 \%$ ), pois, reconhecidamente, a flotação é bastante eficiente para a remoção de algas e cianobatérias e, portanto, da parcela intracelular de microcistina que é a mais representativa do montante total. Conforme REALI et al (1993), a clarificação de água bruta contendo alta concentração de algas em suspensão (água preparada em laboratório) empregando-se uma unidade de flotação em escala de laboratório, apresentou eficiência de remoção de algas superior a 97\% em condições adequadas de coagulação e floculação prévias.

Já com relação à toxina extracelular (originalmente dispersa no meio líquido) a eficiência da flotação é comparativamente menor (cerca de $80 \%$ ), pois trata-se da remoção predominante de material dissolvido no meio líquido.

A partir da flotação, observa-se que a diferença entre as concentrações de microcistina total e extracelular passa a ser menor, pois a maior parte do material celular foi removido preliminarmente na flotação. Foi observada eficiência de remoção de microcistina total de $98,4 \%$ na água submetida à flotação e um acréscimo de apenas $0,2 \%$ de eficiência na água filtrada $(98,6 \%)$ tendo como base a concentração de microcistina na água de estudo, indicando, portanto, que a etapa de filtração apresentou contribuição irrelevante para a remoção de microcistina. 
Após a filtração, o salto de qualidade que pôde ser observado em termos de incremento da remoção de microcistina certamente é devido à pós-oxidação com cloro, que provavelmente teve incidência sobre a remoção da parcela extracelular e resultou em uma eficiência de remoção final da ordem de $98 \%$, tendo com base a concentração de microcistina extracelular na água de estudo de $15 \mu g . L^{`} 1$ e a concentração final da ordem de $0,4 \mu \mathrm{g} \cdot \mathrm{L}^{-1}$ na água pós-oxidada segundo dosagem de cloro de $7,0 \mathrm{mg} \cdot \mathrm{L}^{-1}$ e tempo de contato de 30 minutos.

\section{3 - Inter-Oxidação com Permanganato de Potássio}

5.3.1 - ETAPA I - Investigação das Condições de Coagulação da Água de Estudo e Avaliação da Máxima Dosagem Viável de Permanganato de Potássio na Água submetida à flotação

Nesta ETAPA I foi usada a Água de Estudo 2 com as características qualitativas apresentadas na 5.19 .

Tabela 5.9 - Características Qualitativas de Água de Estudo 2

\begin{tabular}{|c|c|c|}
\hline Parâmetro & Valor & Unidade \\
\hline Cor aparente & 880 & $\mathrm{uH}$ \\
\hline Turbidez & 19 & $\mathrm{uT}$ \\
\hline $\mathrm{pH}$ & 8,72 & - \\
\hline ST & 62 & mg.L $\mathrm{L}^{-1}$ \\
\hline DQO & 100 & $\mathrm{mgO}_{2} \cdot \mathrm{L}^{-1}$ \\
\hline $\mathrm{N}$ amoniacal & 2,50 & mgN-NH${ }_{4}^{+} \cdot \mathrm{L}^{-1}$ \\
\hline Absorbância a 254 nm (*) & 0,32 & - \\
\hline Alcalinidade total & 98 & $\mathrm{mgCaCO}_{3} \cdot \mathrm{L}^{-1}$ \\
\hline Manganês Total & 0,02 & mgMn.L ${ }^{-1}$ \\
\hline Microcistina & 15,7 & $\mu g . L^{-1}$ \\
\hline
\end{tabular}

ND - Não detectado (abaixo do limite de detecção do método)

$(*)$ - Comprimento do caminho óptico igual a 1,0 cm. 
Após a realização de 8 ensaios de coagulação, floculação e flotação da água de estudo, seguindo o mesmo método dos ensaios anteriores, foram observadas boas condições de tratabilidade com uma dosagem de cloreto férrico de $65 \mathrm{mg} \cdot \mathrm{L}^{-1}$ e $\mathrm{pH}$ de coagulação, decorrente dessa dosagem, de 6,67. Para essas condições de tratabilidade foram obtidos valores de cor aparente e turbidez respectivamente iguais a 11,0 uH e 0,11 uT, que correspondem a eficiências de remoção de cor de aproximadamente $99 \%$ e de remoção de turbidez de cerca de $95 \%$.

Com a melhor condição de tratabilidade (dosagem de cloreto férrico de $65 \mathrm{mg} \cdot \mathrm{L}^{-1} \mathrm{e}$ sem adição de ácido ou álcali) foram feitos 16 ensaios de coagulação, floculação e flotação que resultaram na produção de 16 litros de água submetida à flotação para ser utilizada nos ensaios de oxidação subseqüentes. Somente para efeito de avaliação da qualidade final da água tratada produzida, uma amostra da água submetida à flotação também foi filtrada a vácuo em papel Whatmam 40 . A qualidade das águas flotada e filtrada é apresentada na tabela 5.10.

Tabela 5.10 - Ensaios de Inter-oxidação com Permanganato de Potássio. Características Qualitativas das Águas Flotada e Filtrada Produzidas.

\begin{tabular}{|c|c|c|c|}
\hline \multirow[t]{2}{*}{ Parâmetro } & \multicolumn{2}{|c|}{ Valores } & \multirow[t]{2}{*}{ Unidade } \\
\hline & A Flot & A Filt & \\
\hline Cor aparente & 10 & 9 & $\mathrm{uH}$ \\
\hline Turbidez & 0,60 & 0,45 & $\mathrm{uT}$ \\
\hline $\mathrm{pH}$ & 7,94 & 7,95 & - \\
\hline ST & 5 & 2 & mg.L ${ }^{-1}$ \\
\hline DQO & 11 & ND & $\mathrm{mgO}_{2} \cdot \mathrm{L}^{-1}$ \\
\hline N Amoniacal & 2,15 & 2,05 & $\mathrm{mgN}-\mathrm{NH}_{4}{ }^{+} \cdot \mathrm{L}^{-1}$ \\
\hline Absorbância a 254 nm (*) & 0,09 & 0,09 & - \\
\hline Alcalinidade total & 40 & 32 & $\mathrm{mgCaCO}_{3} \cdot \mathrm{L}^{-1}$ \\
\hline
\end{tabular}

ND - Não detectado (abaixo do limite de detecção do método)

$(*)$ - Comprimento do caminho óptico igual a $1,0 \mathrm{~cm}$. 
Finalizando essa primeira etapa de ensaios foi avaliada a máxima dosagem viável de permanganato de potássio na água submetida à flotação sem o comprometimento dos padrões de potabilidade da água filtrada final. Para tanto foram avaliadas diferentes dosagens de permanganato de potássio associado ou não ao cloro, bem como diferentes tempos de contato na etapa de oxidação. Os resultados dessa avaliação são apresentados nas tabela 5.11 e 5.12 e nas figuras 5.10 a 5.12

Tabela 5.11 - Cor, Turbidez e Manganês Total após a Aplicação de Permanganato de Potássio na Água submetida à flotação, com Tempo de Contato de 60 minutos antes da filtração.

\begin{tabular}{cccccccc}
\hline \hline $\begin{array}{c}\text { Dosagem } \\
\mathbf{M n O}_{4}^{-} \\
\left(\mathbf{m g . L}^{-1}\right)\end{array}$ & $\begin{array}{c}\text { A flot } \\
\mathbf{( 1 )}\end{array}$ & $\begin{array}{c}\text { A flot Ox } \\
\mathbf{( 2 )}\end{array}$ & $\begin{array}{c}\text { A filt } \\
\mathbf{( 3 )}\end{array}$ & $\begin{array}{c}\text { A flot } \\
\mathbf{( 1 )}\end{array}$ & $\begin{array}{c}\text { A flot Ox } \\
\mathbf{( 2 )}\end{array}$ & $\begin{array}{c}\text { A filt } \\
\mathbf{( 3 )}\end{array}$ & $\begin{array}{c}\text { A filt } \\
\text { (3) }\end{array}$ \\
\hline \hline 0,2 & 10 & 41 & 12 & 0,60 & 1,82 & 0,38 & 0,02 \\
\hline 0,3 & 10 & 55 & 18 & 0,60 & 1,75 & 0,48 & 0,04 \\
\hline 0,5 & 10 & 69 & 22 & 0,60 & 1,87 & 0,70 & 0,07 \\
\hline 1,0 & 10 & 99 & 33 & 0,60 & 2,50 & 1,14 & 0,11 \\
\hline \hline
\end{tabular}

1- Amostra coletada após a flotação;

2 - Amostra coletada após a oxidação da água submetida à flotação;

3 - Amostra coletada após a filtração da água oxidada com o permanganato de potássio. 
Tabela 5.12 - Cor, Turbidez e Manganês Total com a Aplicação de Permanganato de Potássio na água submetida à flotação, com Tempo de Contato de 15 minutos antes da filtração.

\begin{tabular}{|c|c|c|c|c|c|c|c|}
\hline \multirow{2}{*}{$\begin{array}{c}\text { Dosagem } \\
\mathrm{MnO}_{4}^{-} \\
\left(\mathrm{mg.L}^{-1}\right)\end{array}$} & \multicolumn{3}{|c|}{ Cor (uH) } & \multicolumn{3}{|c|}{ Turb (uT) } & \multirow{2}{*}{$\begin{array}{c}\begin{array}{c}\text { Mn total } \\
\left.\text { (mgMn.L }^{-1}\right)\end{array} \\
\begin{array}{c}\text { A filt } \\
(3)\end{array}\end{array}$} \\
\hline & $\begin{array}{l}\text { A flot } \\
\text { (1) }\end{array}$ & $\begin{array}{l}\text { A flot Ox } \\
\text { (2) }\end{array}$ & $\begin{array}{l}\text { A filt } \\
\text { (3) }\end{array}$ & $\begin{array}{c}\text { A flot } \\
\text { (1) }\end{array}$ & $\begin{array}{l}\text { A flot Ox } \\
\text { (2) }\end{array}$ & $\begin{array}{c}\text { A filt } \\
\text { (3) }\end{array}$ & \\
\hline 0,2 & 10 & 38 & 14 & 0,6 & 0,95 & 0,38 & 0,02 \\
\hline 0,3 & 10 & 48 & 21 & 0,6 & 1,38 & 0,51 & 0,04 \\
\hline
\end{tabular}

1 - Amostra coletada após a flotação;

2 - Amostra coletada após a oxidaçãod a água submetida à flotação;

3 - Amostra coletada após a filtração da água oxidada com o permanganato de potássio.

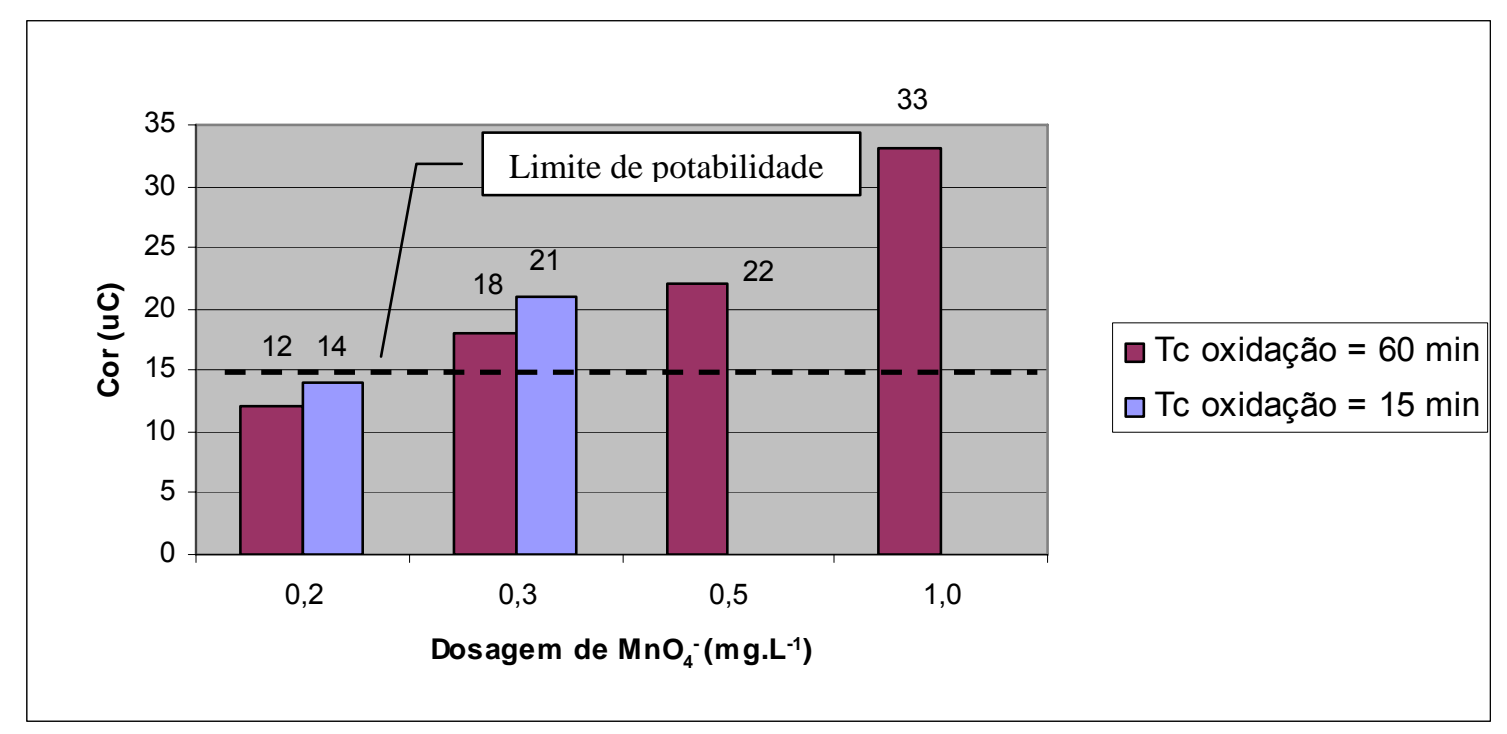

Figura 5.10 - Cor da Água Filtrada na Inter-oxidação com o Permanganato de Potássio. Tempos de contato para oxidação de 15 e 60 minutos. 


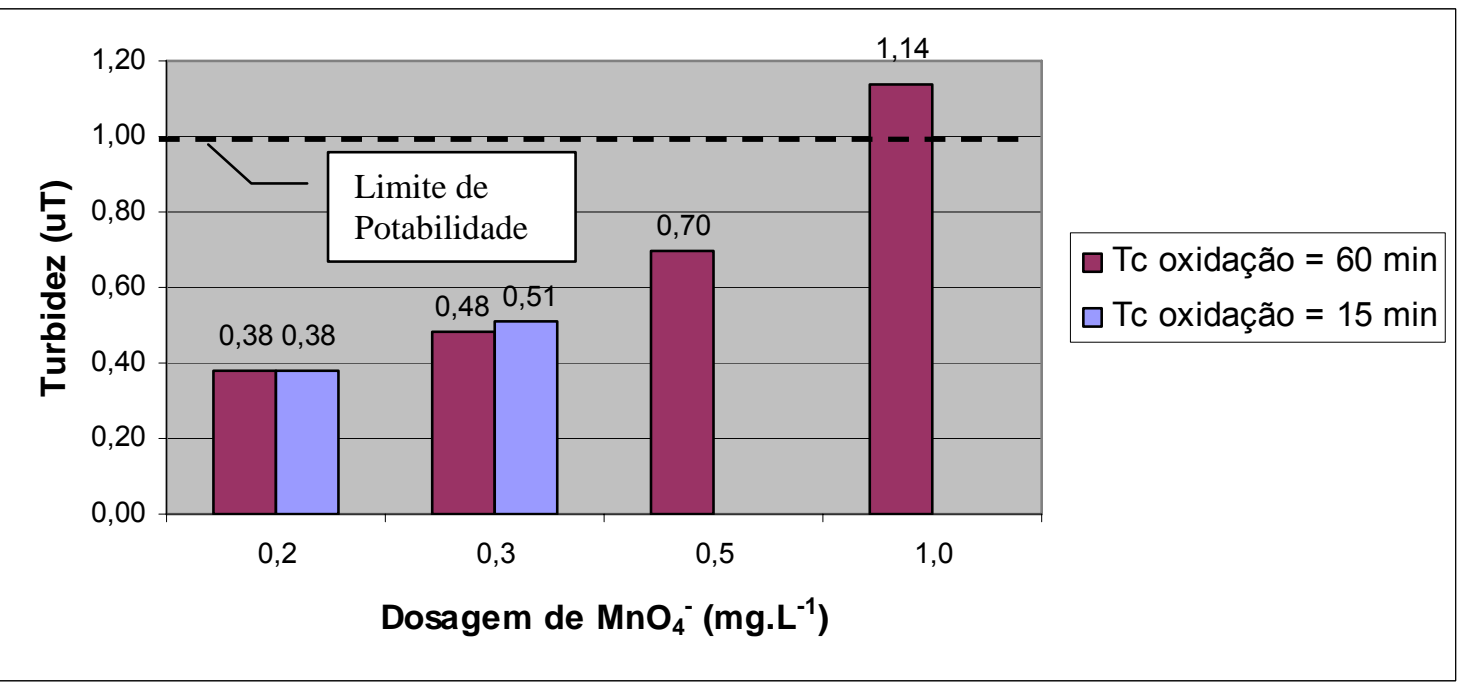

Figura 5.11 - Turbidez da Água Filtrada na Inter-oxidação com o Permanganato de Potássio. Tempos de contato para oxidação de 15 e 60 minutos.

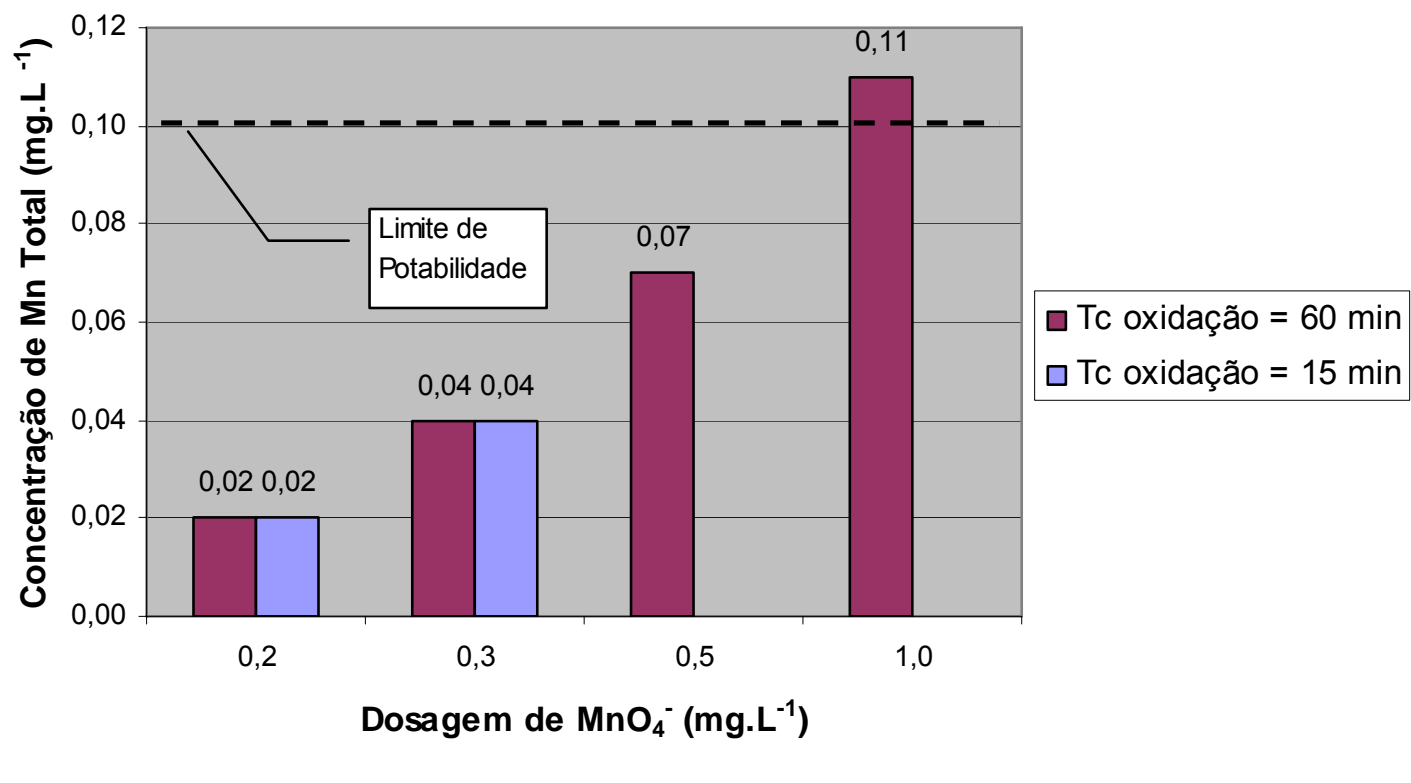

Figura 5.12 - Concentração Remanescente de Manganês Total na Água Filtrada na Interoxidação com o Permanganato de Potássio. Tempos de contato para oxidação de 15 e 60 minutos. 
Analisando os resultados obtidos observa-se que principalmente com relação à cor ocorre grande comprometimento da qualidade da água filtrada com o aumento da dosagem de permanganato de potássio e a redução do tempo de contato para a oxidação.

Com relação à turbidez e à concentração remanescente de manganês total, observa-se que esse comprometimento é menos significativo, sendo observado somente para a dosagem de $1,0 \mathrm{mg} \cdot \mathrm{L}^{-1}$ e tempo de contato de 60 minutos. Provavelmente, a situação seria agravada para o tempo de contato de 15 minutos.

A diferença de resultados decorrente da variação do tempo de contato pode ser justificada pela maior formação de óxidos mangânicos e sua retenção na coluna de areia no caso do maior tempo de detenção.

Portanto, nos ensaios realizados, a máxima dosagem de permanganato de potássio na água submetida à flotação que não comprometeu a qualidade da água filtrada foi de $0,2 \mathrm{mg} / . \mathrm{L}^{-1}$, para ambos os tempos de contato avaliados (15 e 60 minutos).

Já com relação à associação do permanganato de potássio e do cloro aplicados na água submetida à flotação, foram obtidos os resultados apresentados na tabela 5.13 e nas figuras 5.13 a 5.15 . 
Tabela 5.13 - Cor, Turbidez e Manganês Total na Aplicação de Permanganato de Potássio e Cloro na água submetida à flotação, com Tempo de Contato de 60 minutos antes da filtração. Dosagem de cloro $=3,0 \mathrm{mg} \cdot \mathrm{L}^{-1}$.

\begin{tabular}{cccccccc}
\hline \hline $\begin{array}{c}\text { Dosagem } \\
\mathbf{M n O}_{\mathbf{4}}^{-} \\
\left(\mathbf{m g . L}^{-\mathbf{1}}\right)\end{array}$ & A flot & A flot Ox & A filt & A flot & A flot Ox & A filt & A filt \\
\hline \hline 0,3 & 10 & 40 & 17 & 0,6 & 0,95 & 0,50 & $\begin{array}{c}\text { Mn total } \\
\text { (mgMn. }\end{array}$ \\
\hline 0,5 & 10 & 42 & 26 & 0,6 & 0,97 & 0,66 & 0,13 \\
\hline \hline
\end{tabular}

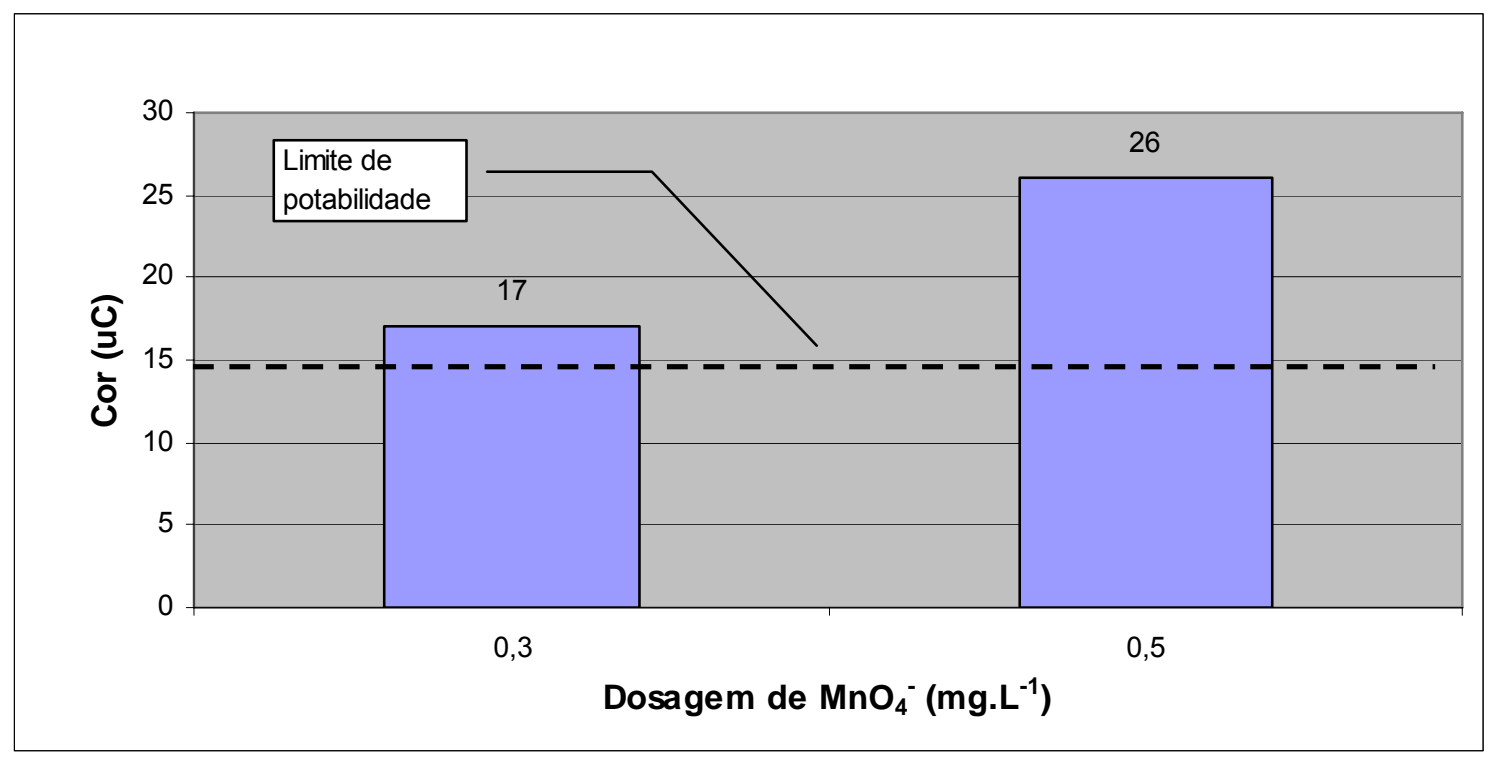

Figura 5.13 - Cor da Água Filtrada nos Ensaios de Inter-oxidação com o Permanganato de Potássio e Cloro. Dosagem de cloro de 3,0 mg. $\mathrm{L}^{-1}$, tempo de contato para a oxidação de 15 minutos. 


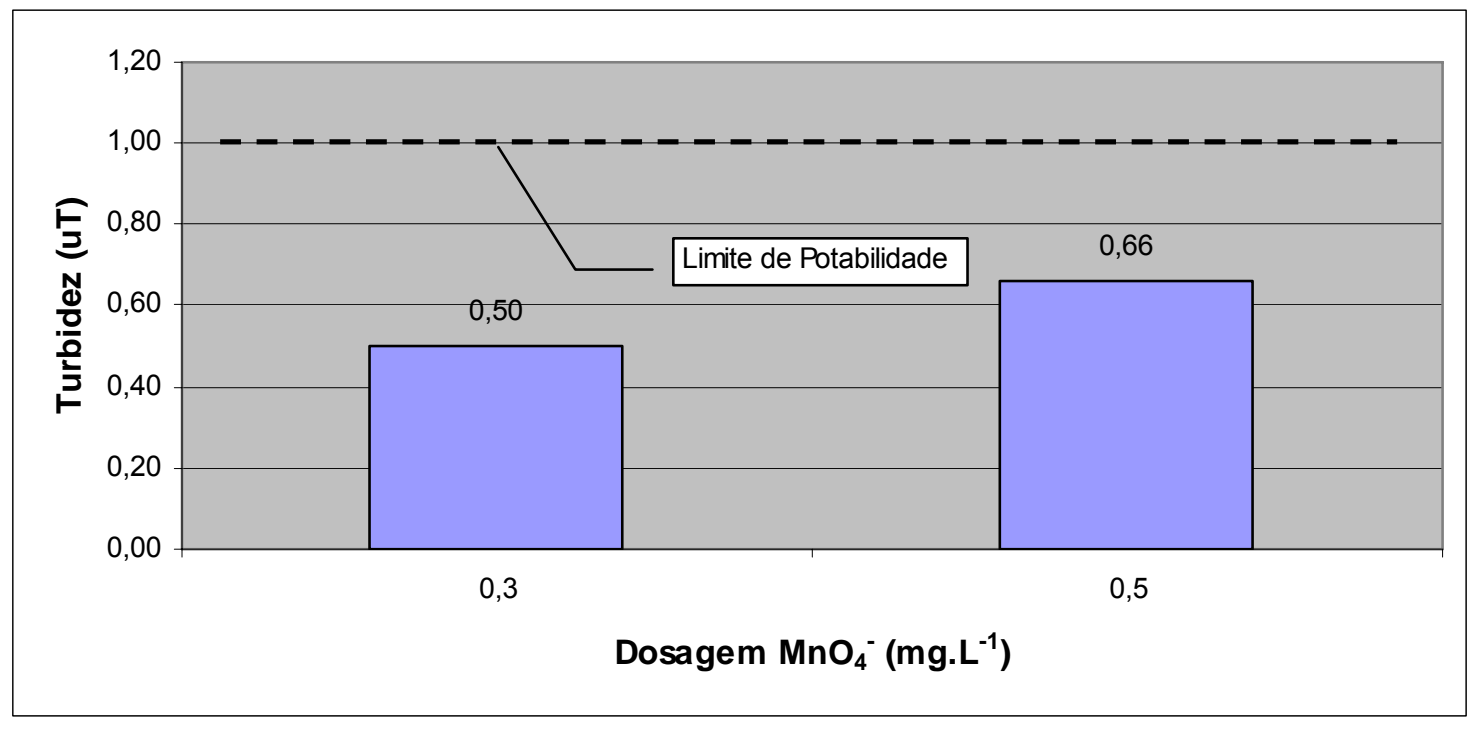

Figura 5.14 - Turbidez da Água Filtrada nos Ensaios de Inter-oxidação com o Permanganato de Potássio e Cloro. Dosagem de cloro de 3,0 mg. $\mathrm{L}^{-1}$, tempo de contato para a oxidação de 15 minutos.

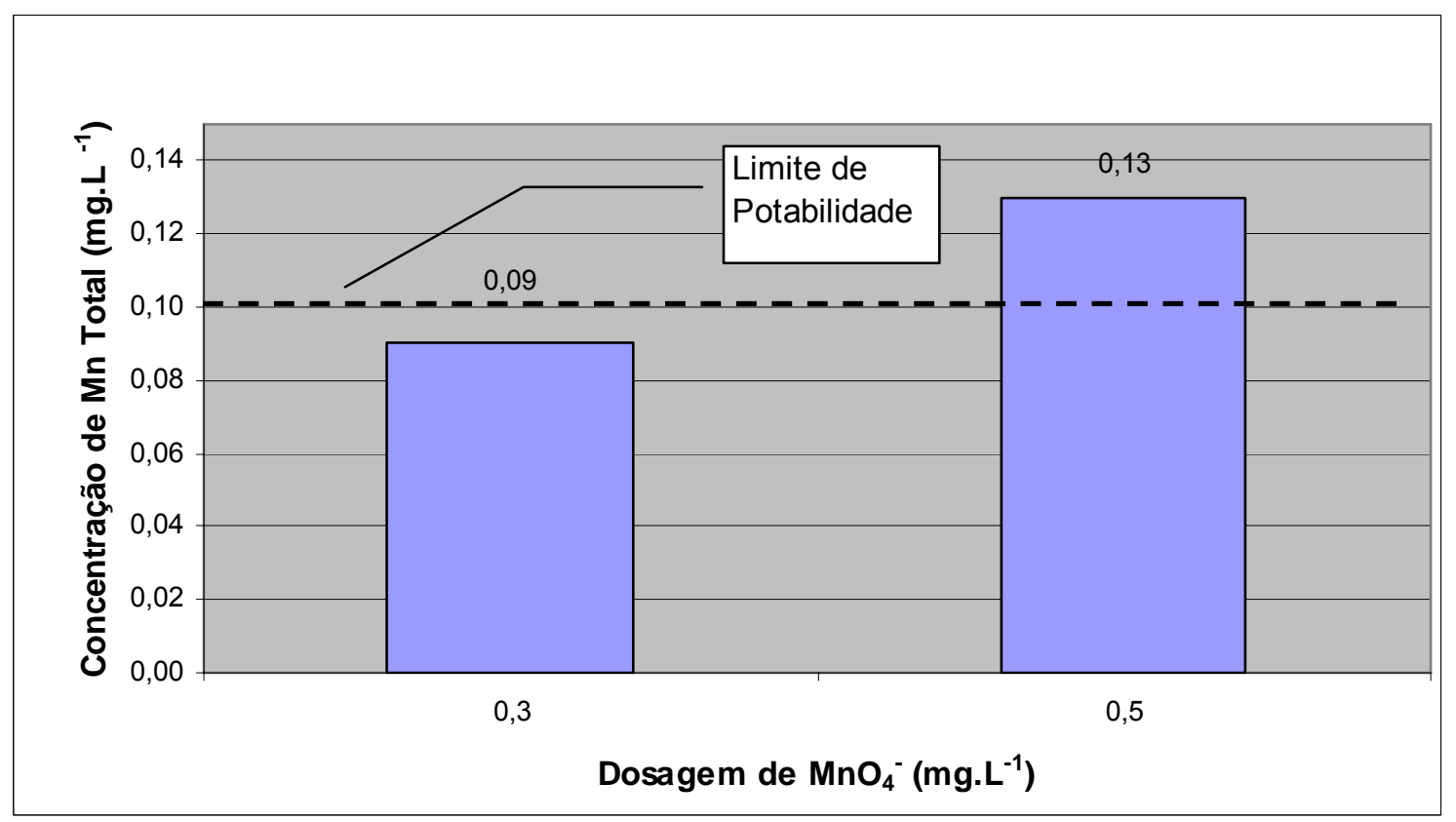

Figura 5.15 - Concentração Remanescente de Manganês Total na Água Filtrada na Interoxidação com o Permanganato de Potássio e Cloro, tempo de contato de 15 minutos.

Com a aplicação do cloro associado ao permanganato de potássio na água submetida à flotação (cloro aplicado 60 segundos antes do permanganato de 
potássio), observa-se que a dosagem de $0,3 \mathrm{mg} \cdot \mathrm{L}^{-1}$ de permanganato e tempo de contato de 15 minutos é viável em termos práticos, pois a cor na água filtrada da ordem de 17 uH está bem próxima do limite do padrão de potabilidade.

Portanto, a aplicação do cloro em conjunto com o permanganato de potássio possibilitou um aumento da dosagem de $\mathrm{MnO}_{4}{ }^{-}$de 0,2 para $0,3 \mathrm{mg} \cdot \mathrm{L}^{-1}$, considerando um tempo de contato de oxidação de apenas 15 minutos.

Observa-se que, ao contrário da pós oxidação (aplicação do oxidante após a etapa de filtração), a oxidação da água submetida à flotação, em termos práticos não é interessante para tempos de contato muito elevados (da ordem de 30 a 60 minutos), pois isso implicaria na necessidade da colocação de câmaras de contato de grandes dimensões entre as etapas de flotação e filtração.

5.3.2 - ETAPA II - Investigação da Remoção de Microcistina Considerando a Máxima Dosagem Viável de Permanganatode Potássio na Inter-oxidação e a Variação de $p H$

Com a água submetida à flotação produzida na Fase II da ETAPA I, foram realizados os ensaios de oxidação com o permanganato de potássio, sendo que nesta etapa o objetivo foi avaliar a remoção de microcistina considerando a máxima dosagem viável de permanganato de potássio definida na Fase II da ETAPA I e a influência da variação do pH na oxidação. Portanto, foi adotada a seguinte condição de oxidação com o permanganto de potássio:

- Aplicação na água submetida à flotação com dosagem de $\mathrm{MnO}_{4}{ }^{-}=0,2 \mathrm{mg} \cdot \mathrm{L}^{-1}$;

- Tempo de contato antes da filtração = 15 minutos.

Na tabela 5.14 e nas figuras 5.16 e 5.17 são apresentados os resultados obtidos. 
Tabela 5.14 - Influência da variação do pH na remoção de microcistina nos ensaios de oxidação com permanganato de potássio da água submetida à flotação. Concentração de microcistina na água de estudo de $15,7 \mu g . \mathrm{L}^{-1}$.

\begin{tabular}{|c|c|c|c|c|c|}
\hline $\begin{array}{c}\text { Dosagem de } \\
\mathrm{MnO}_{4}^{-} \\
\left(\mathrm{mg}^{-} \mathrm{L}^{-1}\right)\end{array}$ & $\begin{array}{l}\text { Tempo } \\
\text { de } \\
\text { Contato } \\
\text { (min) }\end{array}$ & pH & $\begin{array}{c}\text { Residual } \\
\mathrm{MnO}_{4}^{-} \\
\left.\text {(mg.L }^{-1}\right)\end{array}$ & $\begin{array}{c}\text { Concentração de } \\
\text { Microcistina } \\
\text { A Flot.Ox } \\
\left(\mu \text {.L }^{-1}\right) \\
\end{array}$ & $\begin{array}{c}\text { Eficiência de } \\
\text { Remoção de } \\
\text { Microcistina } \\
\text { (\%) }\end{array}$ \\
\hline 0,2 & 15 & 4,35 & 0,11 & 5,4 & 65,6 \\
\hline 0,2 & 15 & 5,88 & 0,15 & 4,8 & 69,6 \\
\hline 0,2 & 15 & 7,34 & 0,17 & 4,8 & 69,3 \\
\hline 0,2 & 15 & 8,91 & 0,18 & 5,2 & 67,2 \\
\hline 0,2 & 15 & 10,00 & 0,18 & 6,7 & 57,3 \\
\hline
\end{tabular}

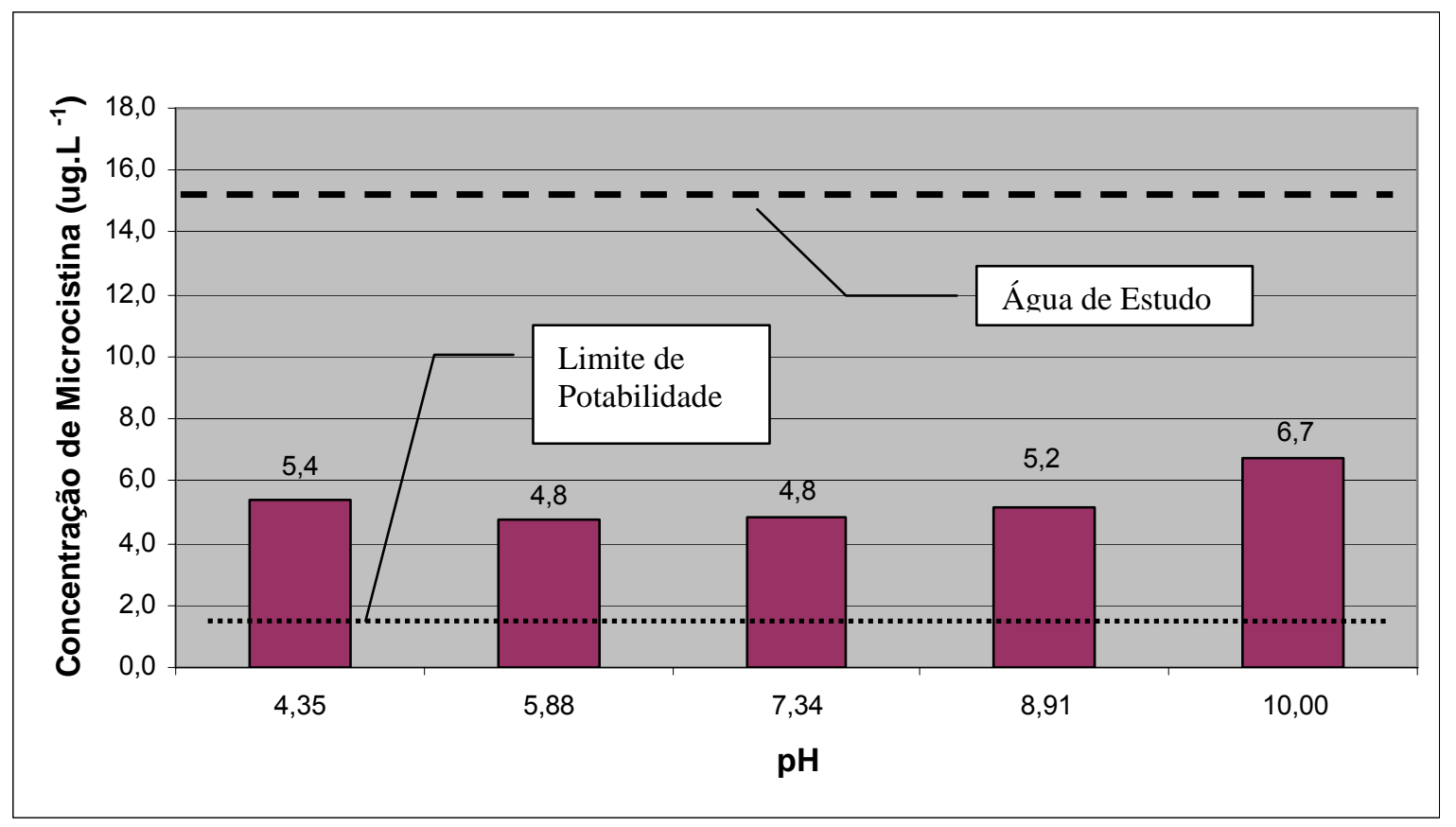

Figura 5.16 - Concentrações Remanescentes de Microcistina após a Oxidação, com Permanganato de Potássio, da água submetida à flotação. Dosagem de Permanganato de $0,2 \mathrm{mg} . \mathrm{L}^{-1}$, tempo de contato para a oxidação de 15 minutos. 


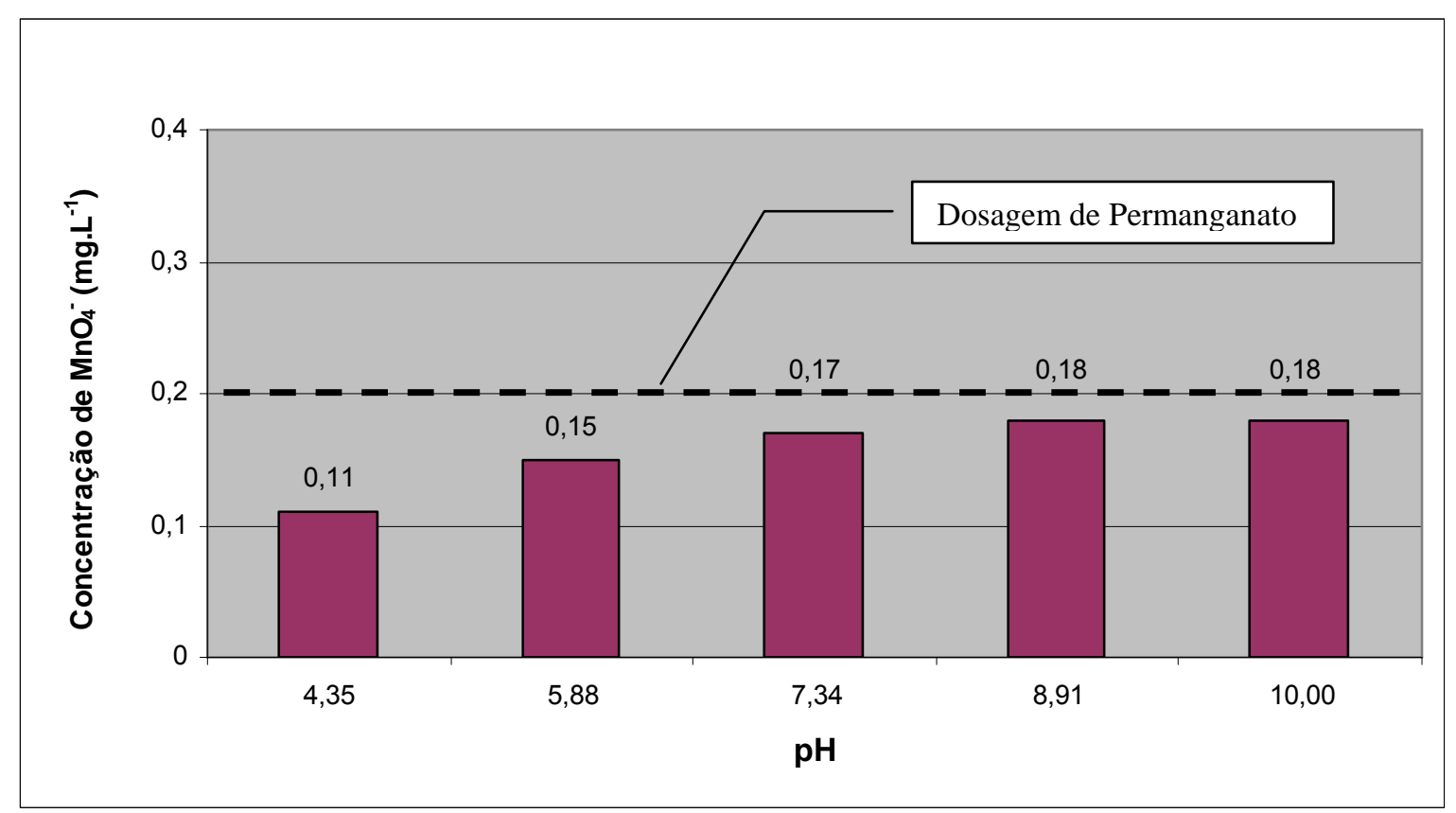

Figura 5.17 - Residuais de Permanganato na Água submetida à flotação. Dosagem de permanganato $=0,2 \mathrm{mg} . \mathrm{L}^{-1}$, tempo de contato de 15 minutos.

Observa-se que a oxidação com dosagem de $\mathrm{MnO}_{4}^{-}$de $0,2 \mathrm{mg} \cdot \mathrm{L}^{-1}$ da água submetida à flotação, não foi efetiva para a remoção da microcistina dentro de padrões aceitáveis. Mesmo havendo a tendência de pequena melhora de desempenho com a redução do pH, a eficiência de remoção de microcistina ficou em torno de 60 a $70 \%$ dentro de toda a faixa de $\mathrm{pH}$ avaliada e o padrão de potabilidade em termos de concentração de microcistina não foi atendido em qualquer condição de ensaio.

Esse baixo desempenho pode ser justificado pela pequena dosagem de permanganato de potássio. Dosagens maiores não foram investigadas por resultarem no comprometimento da cor da água filtrada final, conforme observado nos resultados obtidos na etapa anterior. 
A exemplo do que foi observado na pós-oxidação com cloro, para uma mesma dosagem inicial de permanganato de $0,2 \mathrm{mg} \cdot \mathrm{L}^{-1}$ foi observada uma leve tendência de elevação da concentração residual dessa substância com a elevação dos valores de $\mathrm{pH}$. Esse comportamento apresenta indícios de que a melhoria do processo oxidativo, causada pela queda do $\mathrm{pH}$, pode ser traduzida por um aumento do consumo de permanganato e, portanto, a redução de suas concentrações residuais para uma mesma dosagem inicial.

5.3.3 - ETAPA III - Investigação da Remoção de Microcistina Considerando a Máxima Dosagem Viável de Permanganato de Potássio associado ao Cloro na Interoxidação e a Variação de $p H$

Os ensaios dessa etapa são similares aos descritos no item anterior, diferindo apenas com relação à melhor condição de ensaio verificada para a associação do permanganato de potássio com o cloro aplicados na água submetida à flotação, ou seja: $0,3 \mathrm{mg} \cdot \mathrm{L}^{-1}$ de permanganato associada a $3,0 \mathrm{mg} \cdot \mathrm{L}^{-1}$ de cloro, aplicados sequencialmente na água submetida à flotação (1 minuto de intervalo entre cada aplicação). Os tempos de contato de oxidação foram definidos iguais a 15 minutos para o permanganato de potássio e 14 minutos para o cloro. A tabela 5.15 e as figuras 5.18 e 5.19 apresentam os resultados obtidos. 
Tabela 5.15 - Influência da variação do pH na remoção de microcistina nos ensaios de oxidação, com permanganato de potássio e cloro, da água submetida à flotação

\begin{tabular}{|c|c|c|c|c|c|c|c|}
\hline $\begin{array}{l}\text { Dosagem } \\
{\text { de } \mathrm{MnO}_{4}^{-}}^{-} \\
\left(\mathrm{mg} \cdot \mathrm{L}^{-1}\right)\end{array}$ & $\begin{array}{r}\text { Dosagem } \\
\text { de Cloro } \\
\left(\mathrm{mCl}_{2} \cdot \mathrm{L}^{-1}\right)\end{array}$ & $\begin{array}{l}\text { Tempo } \\
\text { de } \\
\text { Contato } \\
\text { (min) }\end{array}$ & $\mathbf{p H}$ & $\begin{array}{c}\text { Residual } \\
\mathrm{MnO}_{4}^{-} \\
\left(\mathrm{mg.L}^{-1}\right)\end{array}$ & $\begin{array}{c}\text { Residual } \\
\text { Cloro } \\
\left(\mathbf{m g C l}_{2} \cdot \mathbf{L}^{-1}\right)\end{array}$ & $\begin{array}{c}\text { Concentração } \\
\text { Microcistina } \\
\text { na Água } \\
\text { Oxidada } \\
\left(\mu g . L^{-1}\right) \\
\end{array}$ & $\begin{array}{c}\text { Eficiência de } \\
\text { Remoção de } \\
\text { Microcistina } \\
(\%)\end{array}$ \\
\hline 0,3 & 3,0 & 15 & 4,40 & 0,16 & 1,91 & 0,3 & 97,9 \\
\hline 0,3 & 3,0 & 15 & 5,72 & 0,20 & 2,12 & 0,30 & 98,1 \\
\hline 0,3 & 3,0 & 15 & 7,66 & 0,22 & 2,24 & 0,4 & 97,3 \\
\hline 0,3 & 3,0 & 15 & 8,98 & 0,25 & 2,35 & 2,8 & 82,0 \\
\hline 0,3 & 3,0 & 15 & 9,97 & 0,27 & 2,47 & 4,5 & 71,3 \\
\hline
\end{tabular}

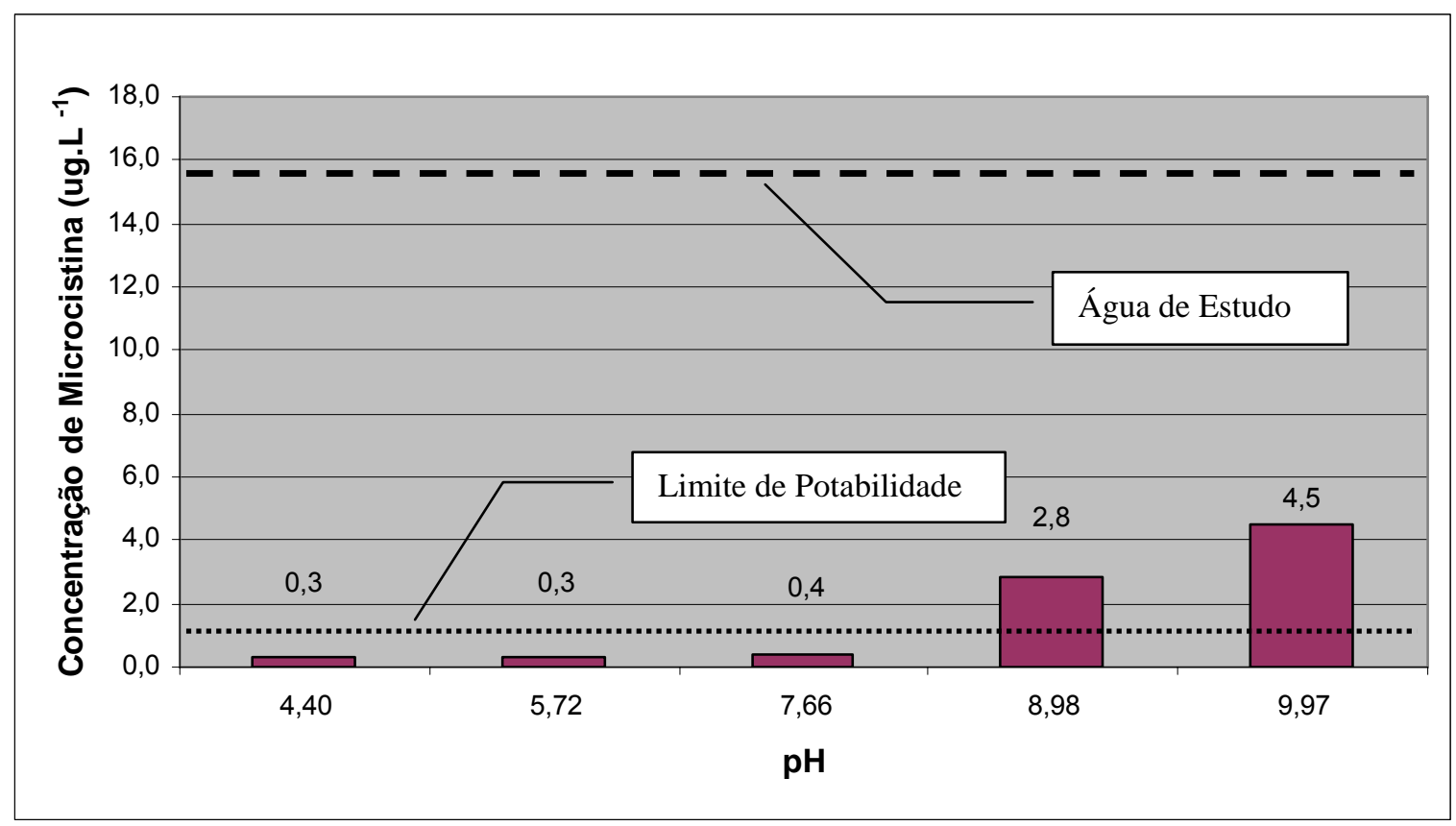

Figura 5.18 - Concentrações remanescentes de microcistina após a oxidação, com permanganato de potássio e cloro, da água submetida à flotação. Dosagem de permanganato de 0,3 mg/l, dosagem de cloro de 3,0 mg/l, tempo de contato para a oxidação de 15 minutos. 


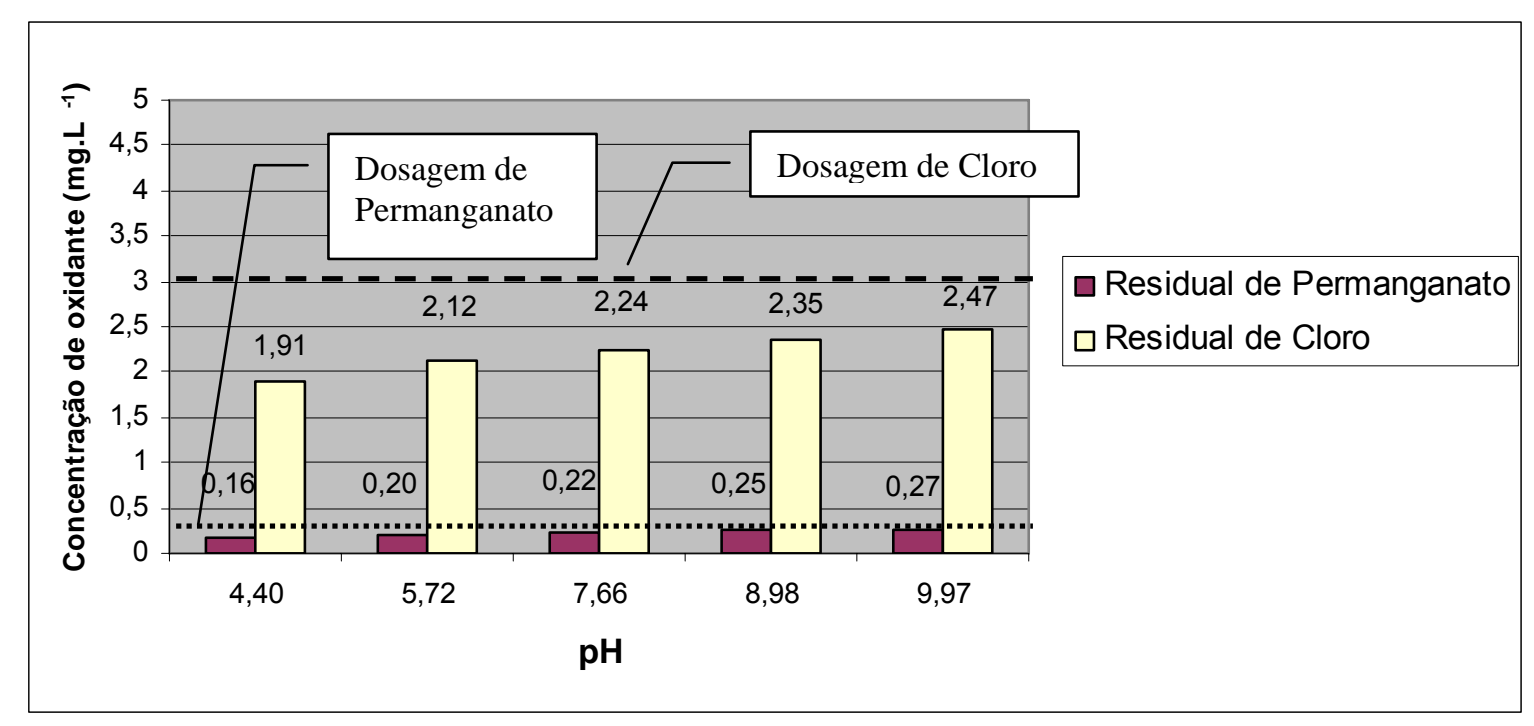

Figura 5.19 - Residuais de permanganato e cloro na água oxidada. Dosagem de permanganato de $0,3 \mathrm{mg} . \mathrm{L}^{-1}$, dosagem de cloro de $3,0 \mathrm{mg} . \mathrm{L}^{-1}$ e tempo de contato para oxidação de 15 minutos.

Em vista dos resultados obtidos observa-se que a associação do cloro com o permanganato de potássio para a oxidação da água submetida à flotação contribuiu de forma significativa para o desempenho da remoção da microcistina, pois concentrações menores que $1,0 \mu \mathrm{g} \cdot \mathrm{L}^{-1}$ foram obtidas com valores de $\mathrm{pH}$ de até 7,70 e eficiências de remoção da ordem de 97 a 98 \% tendo como base a concentração inicial de toxina extracelular de $15,7 \mu \mathrm{g} \cdot \mathrm{L}^{-1}$.

A aplicação conjunta do cloro deve ter contribuído de forma indireta com a melhoria das condições de oxidação da microcistina, pois permitiu a elevação da dosagem de permanganato de 0,2 para $0,3 \mathrm{mg} \cdot \mathrm{L}^{-1} \mathrm{e}$, de forma direta, tendo em vista a sua própria ação oxidativa conforme observado nos ensaios de pós-oxidação com cloro, quando para uma dosagem de cloro livre de $3,0 \mathrm{mg} \cdot \mathrm{L}^{-1}$ a concentração remanescente de microcistina ficou abaixo de $1,0 \mu \mathrm{g} \cdot \mathrm{L}^{-1}$ mesmo para o menor tempo de contato ensaiado de 15 minutos, conforme apresentado na figura 5.4 . 
Novamente observa-se leve tendência de elevação da concentração residual dos oxidantes (permanganato de potássio e cloro) com a elevação dos valores de $\mathrm{pH}$. Esse comportamento apresenta indícios de que a melhoria do processo oxidativo, causada pela queda do $\mathrm{pH}$ pode ser traduzida por um aumento do consumo desses oxidantes e, portanto, a redução de suas concentrações residuais para uma mesma dosagem inicial.

5.3.4 - Considerações com Relação ao Comportamento Global da Remoção da Microcistina nos Diferentes Estágios do Fluxograma de Tratamento

Considerando as concentrações de microcistina na forma extracelular (livre no meio líquido) e total (extracelular e intracelular), que são representadas de forma aproximada pelas amostras submetidas aos ciclos de congelamento e descongelamento, as tabelas 5.16 e 5.17 , bem como as figuras 5.20 e 5.21 , apresentam os resultados dos ensaios de inter-oxidação com permanganato de potássio e de inter-oxidação com a associação do permanganato de potássio e o cloro. 
Tabela 5.16 - Concentrações de Microcistina Intracelular e Extracelular nos Ensaios de Inter-oxidação com Permanganato de Potássio e com a Associação de Permanganato de Potássio e Cloro

\begin{tabular}{cccc}
\hline \hline \multirow{2}{*}{ Amostra } & \multicolumn{2}{c}{ Concentração de Microcistina $\left(\boldsymbol{\mu}\right.$. $\left.\mathbf{L}^{-\mathbf{1}}\right)$} \\
\cline { 2 - 4 } & Total & Intracelular $\left.\mathbf{(}^{\mathbf{1}}\right)$ & Extracelular \\
\hline \hline Água de Barra Bonita & 2,4 & 2,1 & 0,3 \\
\hline Cultura & 2570,0 & 2412,0 & 158,0 \\
\hline Água de Estudo & 338,0 & 322,3 & 15,7 \\
\hline Água submetida à flotação & 13,8 & 0,8 & 13,0 \\
\hline Água inter-oxidada c/ $\mathrm{KMnO}_{4}$ & - & - & $4,8\left(^{2}\right)$ \\
\hline Água inter-oxidada c/ $\mathrm{KMnO}_{4}+\mathrm{Cl}_{2}$ & - & - & $0,4\left(^{3}\right)$ \\
\hline \hline
\end{tabular}

(1) - Diferença entre a microcistina total e a microcistina extracelular.

(2) - Resultado relativo à dosagem de $\mathrm{MnO}_{4}^{-}$de $0,2 \mathrm{mg} \cdot \mathrm{L}^{-1}$, Tc de 15 minutos e pH de oxidação de 7,34 .

(3) - Resultado relativo à dosagem de $\mathrm{MnO}_{4}{ }^{-}$de $0,3 \mathrm{mg} \cdot \mathrm{L}^{-1}$, dosagem de $\mathrm{Cl}_{2}$ de 3,0 mg. $\mathrm{L}^{-1}$, Tc de 15 minutos e pH de oxidação de 7,66.

Tabela 5.17 - Eficiências de Remoção de Microcistina Total e Extracelular nas Diversas Etapas do Fluxograma de tratamento

\begin{tabular}{ccc}
\hline \hline Etapa do Tratamento & \multicolumn{2}{c}{ Eficiências Acumuladas de Remoção (\%) } \\
\cline { 2 - 3 } & $\begin{array}{c}\text { Base - Microcistina } \\
\text { Total }\end{array}$ & $\begin{array}{c}\text { Base - Microcistina } \\
\text { Extracelular }\end{array}$ \\
\hline \hline Flotação & 95,9 & 17,2 \\
\hline Inter-oxidação c/ $\mathrm{KMnO}_{4}$ & & 69,3 \\
\hline Inter-oxidação c/ $\mathrm{KMnO}_{4}+\mathrm{Cl}_{2}$ & & 97,3 \\
\hline \hline
\end{tabular}




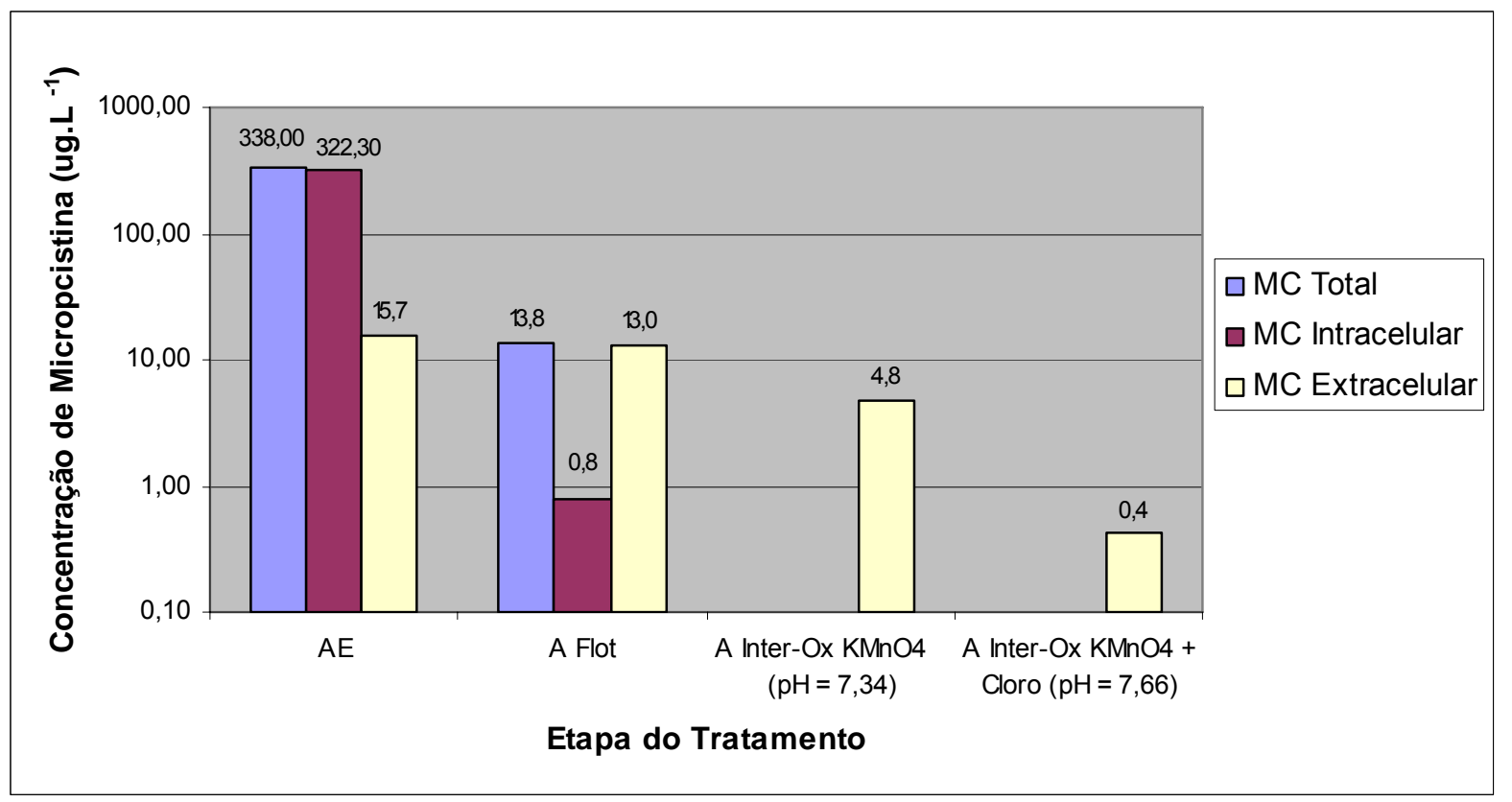

Figura 5.20 - Concentrações Remanescentes de Microcistina ao Longo do Fluxograma de Tratamento. Nos ensaios de inter-oxidação com $\mathrm{KMnO}_{4}$, dosagem de permanganato de 0,2 mg. $L^{-1}$. Nos ensaios de inter-oxidação com a associação do $\mathrm{KMnO}_{4}$ e $\mathrm{Cl}_{2}$ as dosagens de permanganato e cloro foram respectivamente iguais a $0,3 \mathrm{mg} \cdot \mathrm{L}^{-1}$ e 3,0 $\mathrm{mg} . \mathrm{L}^{-1}$.

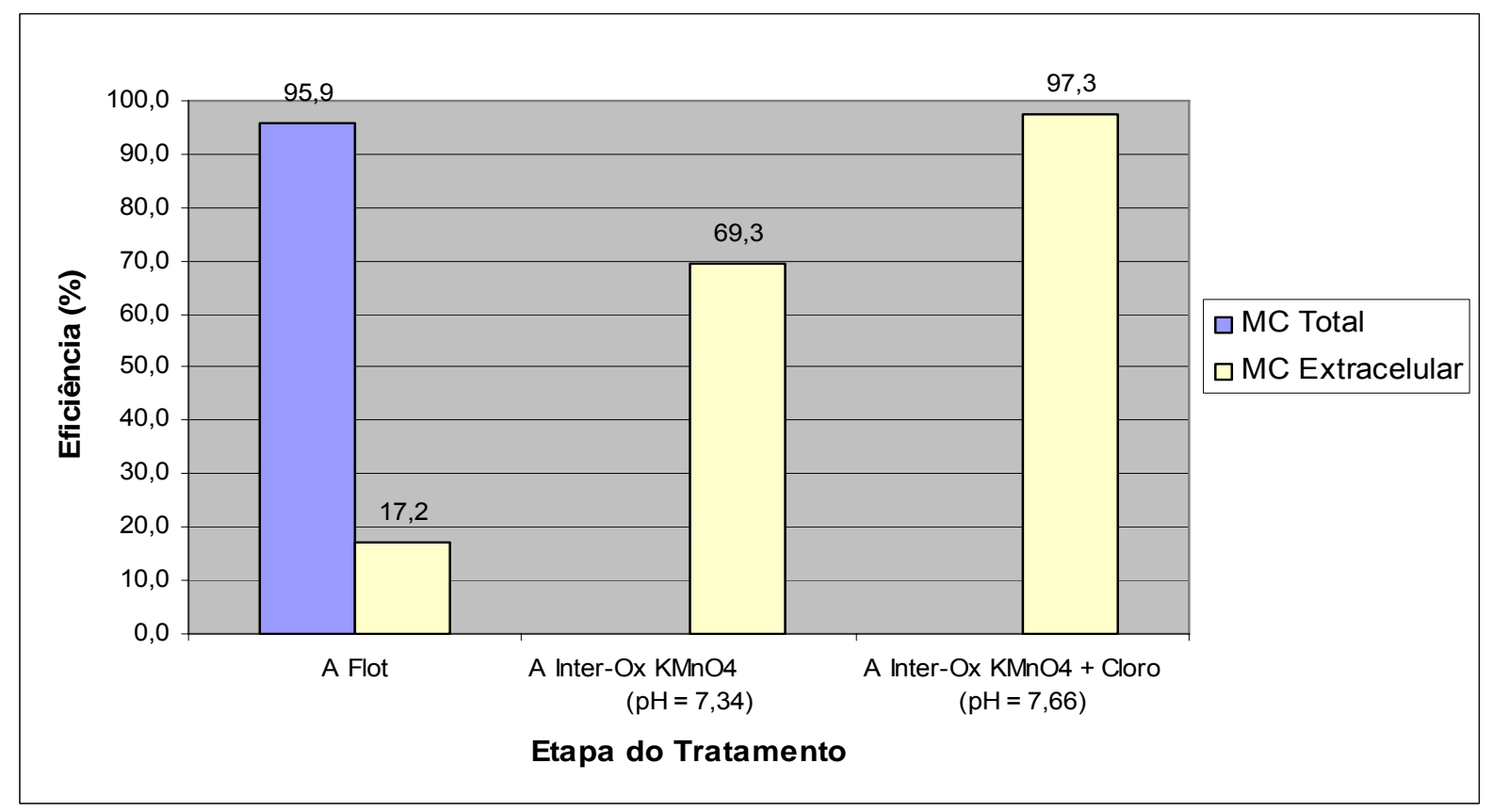

Figura 5.21 - Eficiências de remoção de Microcistina ao Longo do Fluxograma de Tratamento. Nos ensaios de inter-oxidação com $\mathrm{KMnO}_{4}$, dosagem de permanganato de 0,2 mg. ${ }^{-1}$. Nos ensaios de inter-oxidação com a associação do $\mathrm{KMnO}_{4}$ e $\mathrm{Cl}_{2}$ as dosagens de permanganato e cloro foram respectivamente iguais a $0,3 \mathrm{mg} . \mathrm{L}^{-1}$ e 3,0 mg. $\mathrm{L}^{-1}$. 
A exemplo do que foi observado nos resultados dos ensaios de pós-oxidação com cloro apresentados no item 5.2.4, considerando a microcistina total (soma das parcelas intracelular e extracelular), observa-se que em termos de desempenho de remoção, a etapa de flotação apresenta grande eficiência (superior a 95 \%), pois, reconhecidamente, a flotação é bastante eficiente para a remoção de algas e cianobatérias e, portanto, da parcela intracelular que é a mais representativa do montante total. Já com relação à toxina extracelular (originalmente dispersa no meio líquido) a eficiência da flotação é comparativamente bem menor (cerca de 17\%), pois trata-se da remoção predominante de material dissolvido no meio líquido.

Com a oxidação da água préviamente flotada (inter-oxidação) foi observado um salto de qualidade em termos de remoção de microcistina extracelular. No caso da aplicação exclusiva do permanganato de potássio a eficiência de remoção de microcistina foi elevada de $17 \%$ na água submetida à flotação, para cerca de $70 \%$ na água inter-oxidada, resultando em uma concentração remanescente de microcistina de 4,8 $\mu \mathrm{g} \cdot \mathrm{L}^{-1}$. Embora o aumento de eficiência tenha sido significativo, não foi suficiente para o atendimento dos padrões de potabilidade.

No caso da associação do permanganato de potássio com o cloro, a eficiência de remoção de microcistina foi elevada de $17 \%$ na água submetida à flotação, para mais de $97 \%$ na água inter-oxidada, sendo suficiente para o atendimento dos padrões de potabilidade, pois resultou em uma concentração remanescente de microcistina de $0,4 \mu \mathrm{g} \cdot \mathrm{L}^{-1}$. 


\section{4 - Pré-Oxidação com Permanganato de Potássio Associada à Pós-Oxidação com Cloro}

5.4.1 - ETAPA I - Investigação das Condições de Coagulação da Água de Estudo e Avaliação da Máxima Dosagem Viável de Permanganato de Potássio na Água de Estudo

Nesta ETAPA I foi usada a Água de Estudo 3, cujas características qualitativas são apresentadas na tabela 5.18 .

Tabela 5.18 - Características Qualitativas de Água de Estudo 3

\begin{tabular}{ccc}
\hline \hline Parâmetro & Valor & Unidade \\
\hline \hline Cor aparente & 970 & $\mathrm{uH}$ \\
\hline Turbidez & 38 & $\mathrm{uT}$ \\
\hline $\mathrm{pH}$ & 7,58 & - \\
\hline $\mathrm{ST}$ & 130 & $\mathrm{mg} \cdot \mathrm{L}^{-1}$ \\
\hline DQO & 221 & $\mathrm{mgO}_{2} \cdot \mathrm{L}^{-1}$ \\
\hline $\mathrm{N}$ amoniacal & 2,60 & $\mathrm{mgN}-\mathrm{NH}_{4} \cdot \mathrm{L}^{-1}$ \\
\hline Absorbância a 254 nm $\left(^{*}\right)$ & 0,62 & - \\
\hline Alcalinidade total & 113 & $\mathrm{mgCaCO} \cdot \mathrm{L}^{-1}$ \\
\hline Manganês Total & 0,11 & $\mathrm{mgMn} \cdot \mathrm{L}^{-1}$ \\
\hline Microcistina & 17,0 & $\mu \mathrm{Hg} \cdot \mathrm{L}^{-1}$ \\
\hline \hline
\end{tabular}

$(*)$ - Comprimento do caminho óptico igual a $1,0 \mathrm{~cm}$.

Após a realização de 12 ensaios de coagulação, floculação e flotação da água de estudo, seguindo o mesmo método dos ensaios anteriores, foram observados valores de cor e turbidez remanescentes respectivamente iguais a $15 \mathrm{uH}$ e $0,2 \mathrm{uT}$ na água submetida à flotação, para dosagem de cloreto férrico de $140 \mathrm{mg} \cdot \mathrm{L}^{-1}$ e $\mathrm{pH}$ de coagulação decorrente dessa dosagem de 5,20. Ressalta-se que para a finalidade de investigação da pré-oxidação com permanganato de potássio, todos os ensaios 
consideraram também a aplicação de 3,0 mg. $\mathrm{L}^{-1}$ de $\mathrm{MnO}_{4}^{-}$, na água de estudo, 60 segundos antes da aplicação do cloreto férrico.

Para essas condições de tratabilidade foram obtidos valores de cor aparente e turbidez respectivamente iguais a $25,0 \mathrm{uH}$ e $0,17 \mathrm{uT}$, que correspondem a eficiências de remoção de cor de aproximadamente $97 \%$ e de remoção de turbidez de cerca de $99 \%$.

Observa-se que a dosagem de cloreto férrico definida nesta etapa é bem superior aos valores encontrados nos ensaios anteriores (variação em torno de 60 a 80 $\left.\mathrm{mg} \cdot \mathrm{L}^{-1}\right)$. A princípio, essa grande diferença poderia indicar uma inconsistência dos resultados obtidos, entretanto, isso pode ser justificado pelo efeito causado pela adição do permanganato de potássio na água de estudo e a piora de suas condições de tratabilidade, principalmente com a elevação significativa da cor, o que requereu maiores dosagens de coagulante.

Finalizando essa primeira etapa de ensaios foi verificado se a dosagem de 3,0 mg. $\mathrm{L}^{-}$ 1 de permanganato de potássio na água de estudo era viável em termos de atendimento dos padrões de potabilidade da água filtrada final, com relação aos parâmetros de controle cor, turbidez e manganês total.

O ensaio de coagulação, floculação e flotação foi repetido com a dosagem de cloreto férrico de $140 \mathrm{mg} \cdot \mathrm{L}^{-1}$ e a dosagem de permanganato de $3,0 \mathrm{mg} \cdot \mathrm{L}^{-1}$ na água de estudo, sendo que a água filtrada em coluna de areia apresentou os seguintes valores: cor de $8 \mathrm{uH}$, turbidez de 0,06 uT e concentração remanescente de manganês total de $0,14 \mathrm{mg} \cdot \mathrm{L}^{-1}$. 
O valor de $0,14 \mathrm{mg} \cdot \mathrm{L}^{-1}$ ultrapassa o limite de $0,1 \mathrm{mg} \cdot \mathrm{L}^{-1}$ definido no padrão de potabilidade, o que poderia inviabilizar a dosagem de $3,0 \mathrm{mg} \cdot \mathrm{L}^{-1}$ de permanganato de potássio. Entretanto, a água de estudo 3, antes da adição de permanganato de potássio, apresentou concentração de manganês total de $0,11 \mathrm{mg} \cdot \mathrm{L}^{-1}$. Observa-se assim, que na realidade a adição do permanganato de potássio contribuiu apenas com $0,03 \mathrm{mg} \cdot \mathrm{L}^{-1}$ de aumento na concentração inicial de manganês total.

Portanto, foi considerada viável a dosagem de $3,0 \mathrm{mg} \cdot \mathrm{L}^{-1}$ de permanganato na água de estudo e, conseqüentemente, a adoção dessa dosagem para a ETAPA II relativa aos ensaios de pré-oxidação. Na tabela 5.19 são apresentadas as características qualitativas das águas flotada e filtrada produzidas.

Tabela 5.19 - Características Qualitativas das Águas Préviamente Flotada e Filtrada Produzidas

\begin{tabular}{|c|c|c|c|}
\hline \multirow[t]{2}{*}{ Parâmetro } & \multicolumn{2}{|c|}{ Valores } & \multirow[t]{2}{*}{ Unidade } \\
\hline & A Flot & A Filt & \\
\hline Cor aparente & 25 & 8 & $\mathrm{uH}$ \\
\hline Turbidez & 0,17 & 0,06 & $\mathrm{uT}$ \\
\hline $\mathrm{pH}$ & 6,00 & 6,12 & - \\
\hline ST & 8 & 1 & mg. $\mathrm{L}^{-1}$ \\
\hline DQO & 22 & 16 & $\mathrm{mgO}_{2} \cdot \mathrm{L}^{-1}$ \\
\hline N Amoniacal & 2,20 & 2,15 & 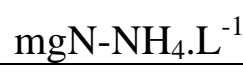 \\
\hline Absorbância a 254 nm (*) & 0,06 & 0,06 & - \\
\hline Alcalinidade total & 11 & 9 & $\mathrm{mgCaCO}_{3} \cdot \mathrm{L}^{-1}$ \\
\hline Manganês total & - & 0,14 & mgMn.L ${ }^{-1}$ \\
\hline
\end{tabular}

$(*)$ - Comprimento do caminho óptico igual a 1,0 cm. 
5.4 .2 - ETAPA II - Investigação da Remoção de Microcistina Considerando a Máxima Dosagem Viável de Permanganato de Potássio na Pré-oxidação Associada à Pós-oxidação com Cloro e a Variação de pH

Para esta etapa os ensaios de tratabilidade foram repetidos até a etapa de flotação, ou seja: aplicação de permanganato de potássio $\left(3,0 \mathrm{mg} \cdot \mathrm{L}^{-1}\right)$ e cloreto férrico (140 $\left.m g \cdot L^{-1}\right)$, coagulação, floculação e flotação.

Com essa condição de ensaio foi produzida água pré-oxidada com permanganato de potássio e posteriormente submetida à flotação, que nesta etapa foi submetida à pós-oxidação com cloro segundo duas dosagens distintas: $3,0 \mathrm{mg} \cdot \mathrm{L}^{-1}$ para um grupo de ensaios e $7,0 \mathrm{mg} \cdot \mathrm{L}^{-1}$ para o outro grupo. Para cada grupo foram variados os valores de $\mathrm{pH}$ de oxidação com cloro.

Observa-se que a aplicação do cloro foi feita na água submetida à flotação e não na água filtrada, o que contraria o procedimento mais usual. Entretanto, isso foi adotado no caso em questão para acelerar os ensaios de laboratório, evitando que o tempo de contato de oxidação fosse excessivo, pois a filtração da água submetida à flotação demandaria muito tempo (certamente mais de 30 minutos para todas as amostras a serem ensaiadas). Essa adaptação de método não comprometeu de forma significativa os resultados, pois não existia grande diferença entre a qualidade da água submetida à flotação e a água filtrada e, portanto, grande diferença entre as demandas de oxidante e de substâncias interferentes.

Na tabela 5.20 e nas figuras 5.22 e 5.23 são apresentados os resultados dos ensaios em que se aplicou dosagem de cloro de $3,0 \mathrm{mg} \cdot \mathrm{L}^{-1}$ na pós-oxidação. 
Tabela 5.20 - Influência da variação do pH na remoção de microcistina nos ensaios de pré-oxidação com permanganato de potássio, flotação e pós-oxidação com cloro. Dosagem de cloro de 3,0 mg. $\mathrm{L}^{-1}$.

\begin{tabular}{|c|c|c|c|c|c|c|c|}
\hline $\begin{array}{c}\text { Dosagem } \\
\text { MnO4 } \\
\text { Água } \\
\text { Estudo } \\
\left(\mathrm{mg.L}^{-1}\right) \\
\end{array}$ & $\begin{array}{c}\text { Dosagem } \\
\text { Cloro } \\
\text { Água } \\
\text { Filtrada } \\
\left(\mathbf{m g C l}_{\left.\mathbf{2} . \mathbf{L}^{-1}\right)}\right. \\
\end{array}$ & $\begin{array}{c}\text { Tempo } \\
\text { Contato } \\
\text { Pós- } \\
\text { oxidação } \\
\text { (min) } \\
\end{array}$ & pH & $\begin{array}{c}\text { Residual } \\
\mathrm{MnO}_{4}^{-} \\
\left(\mathrm{mg}^{-} \mathrm{L}^{-1}\right)\end{array}$ & $\begin{array}{l}\text { Residual } \\
\text { de Cloro } \\
\left(\begin{array}{c}\mathrm{mgCl}_{\mathbf{1}} \cdot \mathrm{L}^{-} \\
\mathbf{m}^{-}\end{array}\right.\end{array}$ & $\begin{array}{c}\text { Concentração } \\
\text { Microcistina } \\
\text { Água } \\
\text { Oxidada } \\
\left(\mu g . L^{-1}\right) \\
\end{array}$ & $\begin{array}{c}\begin{array}{c}\text { Eficiência } \\
\text { de }\end{array} \\
\text { Remoção } \\
(\%)\end{array}$ \\
\hline 3,0 & 3,0 & 30 & 4,51 & 0,15 & 1,64 & 0,2 & 98,8 \\
\hline 3,0 & 3,0 & 30 & 6,19 & 0,19 & 1,73 & 0,2 & 99,1 \\
\hline 3,0 & 3,0 & 30 & 7,11 & 0,21 & 1,76 & 0,2 & 98,9 \\
\hline 3,0 & 3,0 & 30 & 8,27 & 0,23 & 1,85 & 0,3 & 98,4 \\
\hline 3,0 & 3,0 & 30 & 10,13 & 0,26 & 2,02 & 0,6 & 96,5 \\
\hline
\end{tabular}

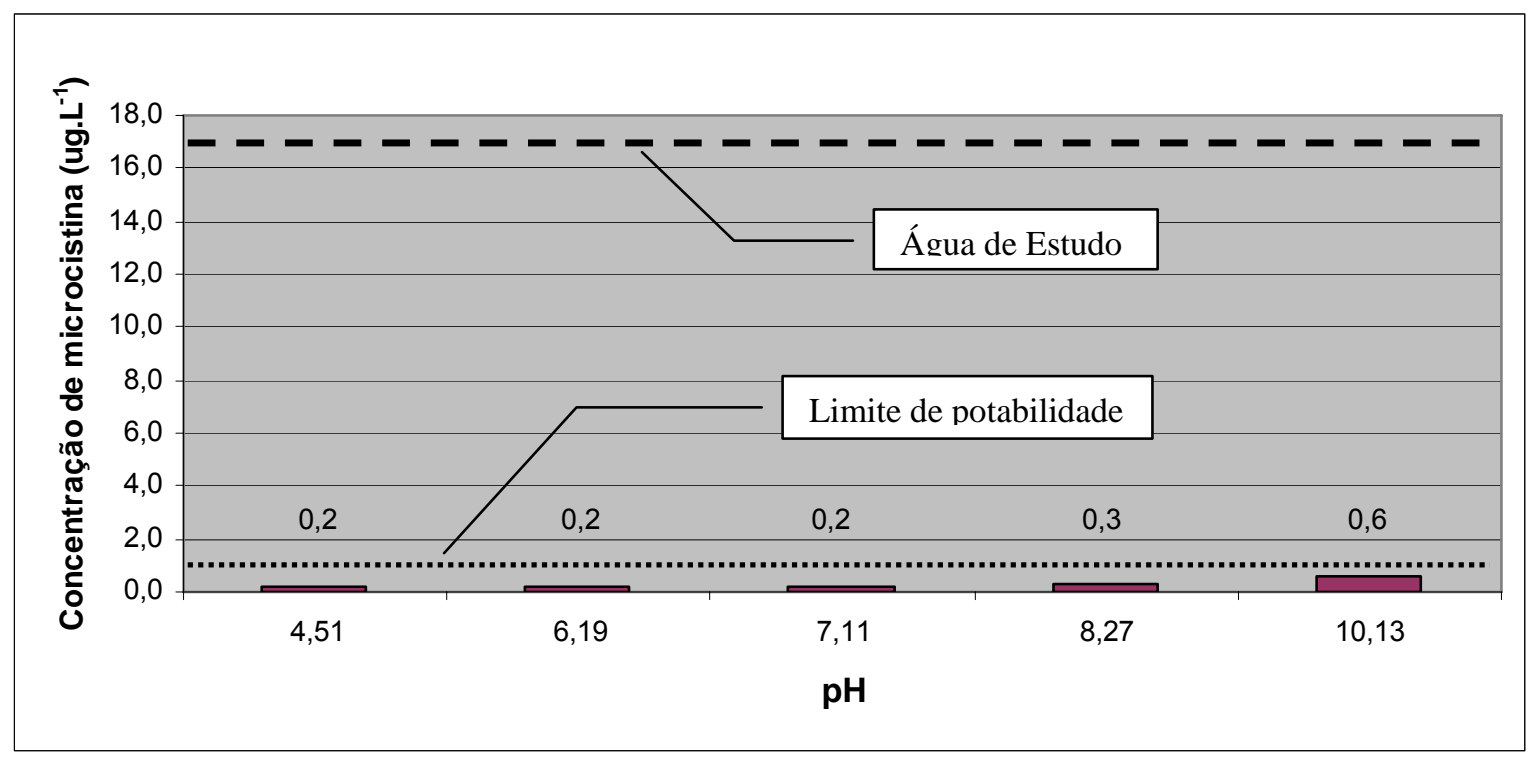

Figura 5.22 - Concentrações remanescentes de Microcistina após a pré-oxidação da água de estudo com permanganato de potássio e pós-oxidação com cloro. Dosagem de permanganto de $3,0 \mathrm{mg} . \mathrm{L}^{-1}$, dosagem de cloro de $3,0 \mathrm{mg} . \mathrm{L}^{-1}$ e tempo de contato para a pósoxidação com cloro de 30 minutos. 


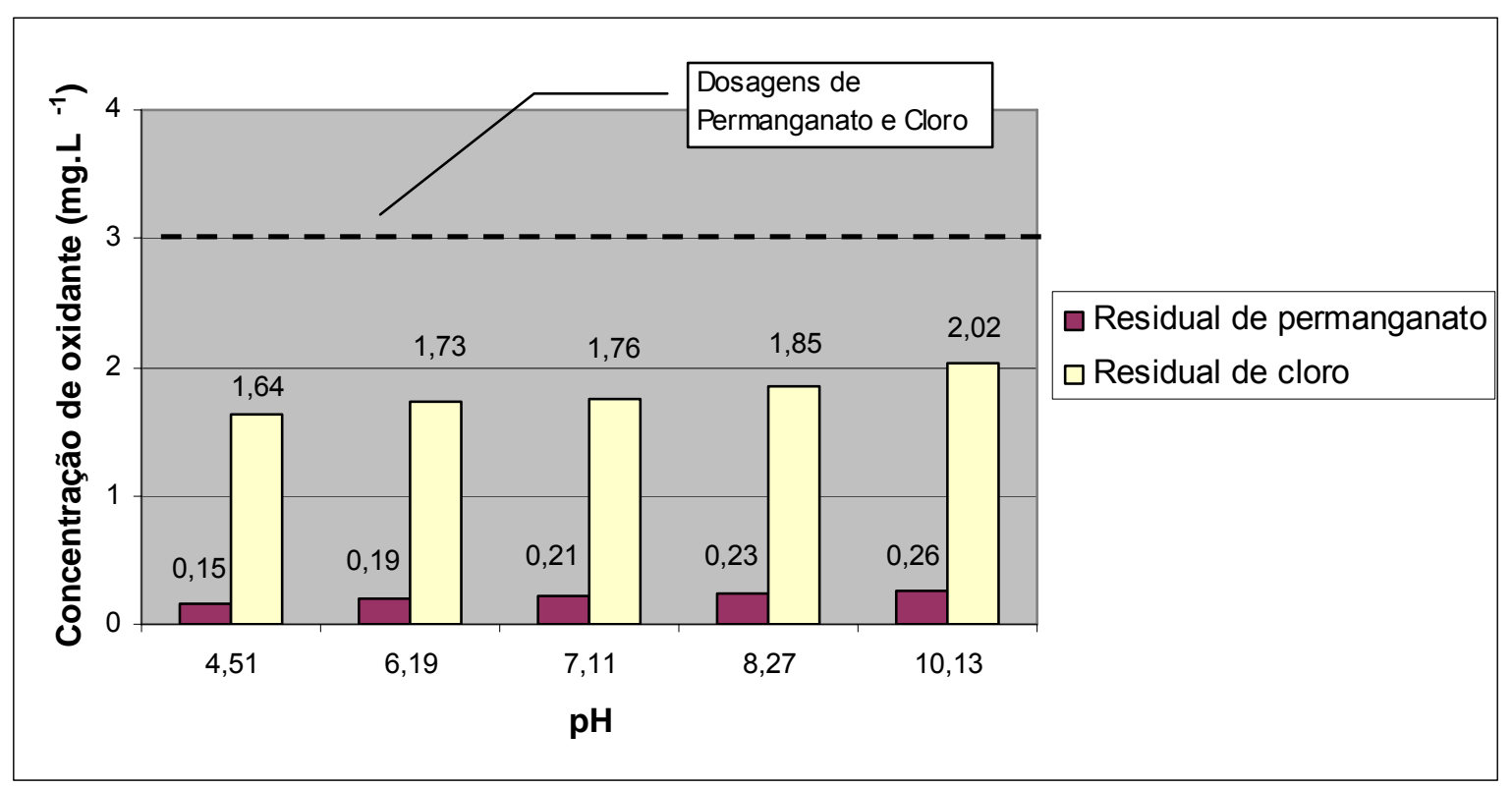

Figura 5.23 - Residuais de permanganato e cloro na água pré-oxidada e submetida à flotação. Dosagem de permanganato de 3,0 mg. $\mathrm{L}^{-1}$, dosagem de cloro de 3,0 mg. $\mathrm{L}^{-1}$ e tempo de contato para a pós-oxidação de 30 minutos.

Mediante os resultados obtidos, observa-se que a associação da pré-oxidação com permanganato de potássio e pós oxidação com cloro, segundo dosagens de oxidantes respectivamente iguais a $3,0 \mathrm{mg} \cdot \mathrm{L}^{-1}$ de $\mathrm{MnO}_{4}^{-}$e $3,0 \mathrm{mg} \cdot \mathrm{L}^{-1}$ de $\mathrm{Cl}_{2}$, foi bastante efetiva para a remoção da microcistina extracelular, pois para toda a faixa de $\mathrm{pH}$ avaliada foi atendido o padrão de potabilidade com concentração de microcistina abaixo de 0,6 mg. $\mathrm{L}^{-1}$ e eficiências de remoção variando de 96 a 99\%.

Para os ensaios com dosagem de $7,0 \mathrm{mg} \cdot \mathrm{L}^{-1}$ de cloro na pós-oxidação, foram obtidos os resultados apresentados na tabela 5.21 e nas figuras 5.24 e 5.25 . 
Tabela 5.21 - Influência da variação do pH na remoção de microcistina nos ensaios de pré-oxidação com permanganato de potássio, flotação e pós-oxidação com cloro. Dosagem de cloro de 7,0 mg. $\mathrm{L}^{-1}$.

\begin{tabular}{|c|c|c|c|c|c|c|c|}
\hline $\begin{array}{c}\text { Dosagem } \\
\mathrm{MnO}_{4}^{-} \\
\text {na Água } \\
\text { de } \\
\text { estudo } \\
\left(\mathrm{mg.L}^{-1}\right) \\
\end{array}$ & $\begin{array}{c}\text { Dosagem } \\
\text { Cloro na } \\
\text { Água } \\
\text { filtrada } \\
\left(\mathrm{mgCl}_{2} / . \mathrm{L}^{-}\right. \\
1) \\
\end{array}$ & $\begin{array}{c}\text { Tempo } \\
\text { Contato } \\
\text { Pós- } \\
\text { oxidação } \\
\text { (min) }\end{array}$ & pH & $\begin{array}{c}\text { Residual } \\
\mathrm{MnO}_{4}^{-} \\
\left(\mathrm{mg}^{-} \mathrm{L}^{-1}\right)\end{array}$ & $\begin{array}{l}\text { Residual de } \\
\text { Cloro } \\
\left(\mathrm{mgCl}_{2} \cdot \mathrm{L}^{-1}\right)\end{array}$ & $\begin{array}{c}\text { Concentração } \\
\text { Microcistina } \\
\text { na Água } \\
\text { Oxidada } \\
\left(\mu g . L^{-1}\right)\end{array}$ & $\begin{array}{c}\text { Eficiência } \\
\text { de } \\
\text { Remoção } \\
(\%)\end{array}$ \\
\hline 3,0 & 7,0 & 30 & 4,65 & 0,17 & 4,80 & 0,2 & 99,0 \\
\hline 3,0 & 7,0 & 30 & 6,43 & 0,23 & 4,95 & 0,2 & 98,9 \\
\hline 3,0 & 7,0 & 30 & 7,55 & 0,22 & 5,02 & 0,2 & 98,8 \\
\hline 3,0 & 7,0 & 30 & 8,90 & 0,24 & 5,05 & 0,3 & 98,2 \\
\hline 3,0 & 7,0 & 30 & 10,32 & 0,25 & 5,1 & 0,4 & 97,6 \\
\hline
\end{tabular}

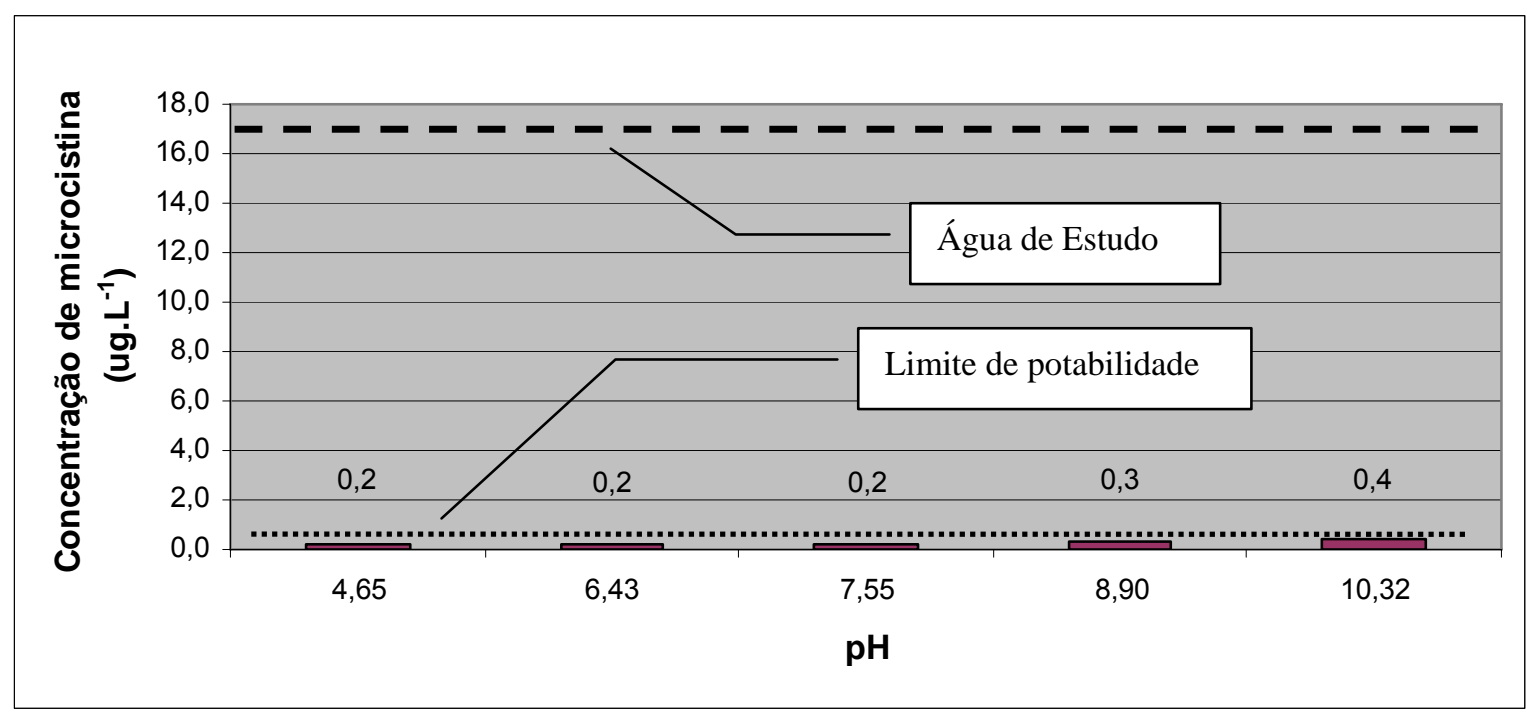

Figura 5.24 - Concentrações remanescentes de Microcistina após a pré-oxidação da água de estudo com permanganato de potássio e pós-oxidação com cloro. Dosagem de permanganato de 3,0 mg. $\mathrm{L}^{-1}$, dosagem de cloro de 7,0 mg. $\mathrm{L}^{-1}$ e tempo de contato para a pósoxidação com cloro de 30 minutos. 


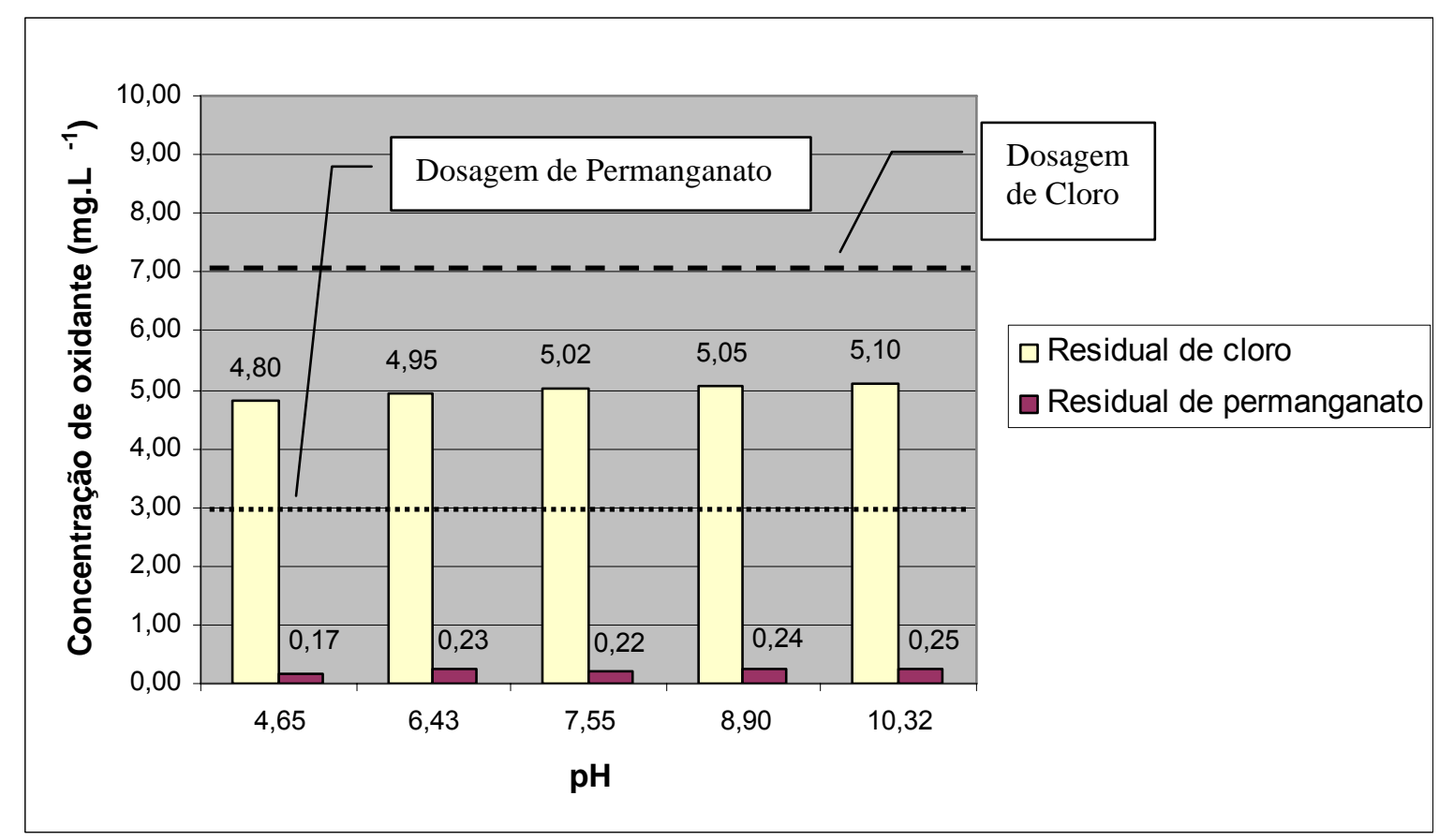

Figura 5.25 - Residuais de permanganato e cloro na água filtrada. Dosagem de permanganato de 3,0 mg. $\mathrm{L}^{-1}$, dosagem de cloro de 7,0 mg. $\mathrm{L}^{-1}$ e tempo de contato para a pósoxidação de 30 minutos.

Em comparação com os ensaios do outro grupo, ou seja: pré-oxidação com permanganato (dosagem de $3,0 \mathrm{mg} \cdot \mathrm{L}^{-1}$ ) e pós-oxidação com cloro (dosagem de 3,0 $\left.\mathrm{mg} \cdot \mathrm{L}^{-1}\right)$, a elevação da dosagem de cloro para $7,0 \mathrm{mg} \cdot \mathrm{L}^{-1}$ na pós-oxidação resultou em um desempenho ainda melhor na remoção da microcistina, com a manutenção do atendimento do padrão de potabilidade para toda a faixa de variação do $\mathrm{pH}$, concentração remanescente de microcistina de $0,4 \mu \mathrm{g} \cdot \mathrm{L}^{-1}$ para a condição de $\mathrm{pH}$ mais elevado e uma eficiência de remoção de microcistina extracelular na faixa 97 a $99 \%$.

Para ambos os grupos de ensaios foi novamente observada tendência de elevação da concentração residual dos oxidantes (permanganato e cloro) com a elevação dos valores de $\mathrm{pH}$. Esse comportamento apresenta indícios de que a melhoria do 
processo oxidativo, causada pela queda do $\mathrm{pH}$ pode ser traduzida por um aumento do consumo desses oxidantes e, portanto, a redução de suas concentrações residuais para uma mesma dosagem inicial.

5.4.3 - Considerações com Relação ao Comportamento Global da Remoção da Microcistina nos Diferentes Estágios do Fluxograma de Tratamento

Considerando as concentrações de microcistina na forma extracelular (livre no meio líquido) e total (extracelular e intracelular), que são representadas de forma aproximada pelas amostras submetidas aos ciclos de congelamento e descongelamento, as tabelas 5.22 e 5.23, bem como as figuras 5.26 e 5.27, apresentam os resultados dos ensaios de pré-oxidação com permanganato de potássio e pós-oxidação com cloro.

Tabela 5.22 - Concentrações de Microcistina Intracelular e Extracelular nos Ensaios de Pré-oxidação com Permanganato de Potássio e Pós-oxidação com Cloro (dosagem de $\mathbf{C l}_{2}$ $=3,0 \mathrm{mg} / \mathrm{L}^{-1}$ )

\begin{tabular}{|c|c|c|c|}
\hline \multirow[t]{2}{*}{ Amostra } & \multicolumn{3}{|c|}{ Concentração de Microcistina ( $\mu g . L^{-1}$ ) } \\
\hline & Total & Intracelular ${ }^{(1)}$ & Extracelular \\
\hline Água de Barra Bonita & 0,4 & 0,3 & 0,1 \\
\hline Cultura & 2291,0 & 2223,0 & 68,0 \\
\hline Água de Estudo & 567,0 & 550,0 & 17,0 \\
\hline Água pré-oxidada e flotada ${ }^{(2)}$ & 1,7 & 0,5 & 1,2 \\
\hline \multicolumn{3}{|l|}{$\begin{array}{l}\text { Água pré-oxidada, flotada e pós- } \\
\text { oxidada }^{(3)}\end{array}$} & 0,6 \\
\hline \multicolumn{4}{|c|}{ (1) - Diferença entre a microcistina total e a microcistina extracelular. } \\
\hline \multicolumn{4}{|c|}{$\begin{array}{l}\text { (2) - Resultado relativo à dosagem de } \mathrm{MnO}_{4}^{-} \text {de } 3,0 \mathrm{mg} \cdot \mathrm{L}^{-1} \text { na água de estudo e posteriormente flotada } \\
\text { (3) - Resultado relativo à dosagem de } \mathrm{MnO}_{4}^{-} \text {de } 3,0 \mathrm{mg} \cdot \mathrm{L}^{-1} \text { na água de estudo, flotação e dosagem de } \\
\mathrm{Cl}_{2} \text { de } 3,0 \mathrm{mg} \cdot \mathrm{L}^{-1} \text { na água submetida à flotação, com Tc de } 30 \text { minutos e pH de pós-oxidação de 10,13. }\end{array}$} \\
\hline
\end{tabular}


Tabela 5.23 - Eficiências de remoção de microcistina total e extracelular nas diversas etapas do fluxograma de tratamento

\begin{tabular}{lcc}
\hline \hline \multirow{2}{*}{ Etapa do Tratamento } & \multicolumn{2}{c}{ Eficiências Acumuladas de Remoção (\%) } \\
\cline { 2 - 3 } & $\begin{array}{c}\text { Base - Microcistina } \\
\text { Total }\end{array}$ & $\begin{array}{c}\text { Base - Parcela } \\
\text { Extracelular }\end{array}$ \\
\hline \hline Pré-oxidação e Flotação (1) & 99,7 & 92,9 \\
\hline Pré-oxidação, flotação e pós-oxidação (2) & - & 96,5 \\
\hline \hline
\end{tabular}

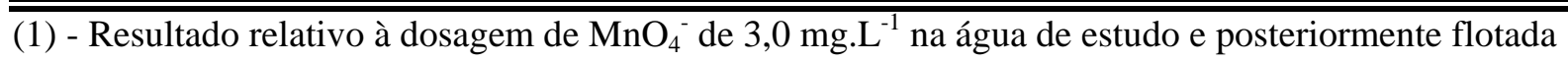

(2) - Resultado relativo à dosagem de $\mathrm{MnO}_{4}{ }^{-}$de 3,0 mg. $\mathrm{L}^{-1}$ na água de estudo, flotação e dosagem de $\mathrm{Cl}_{2}$ de 3,0 mg.L ${ }^{-1}$ na água submetida à flotação, com Tc de 30 minutos e $\mathrm{pH}$ de pós-oxidação de 10,13.

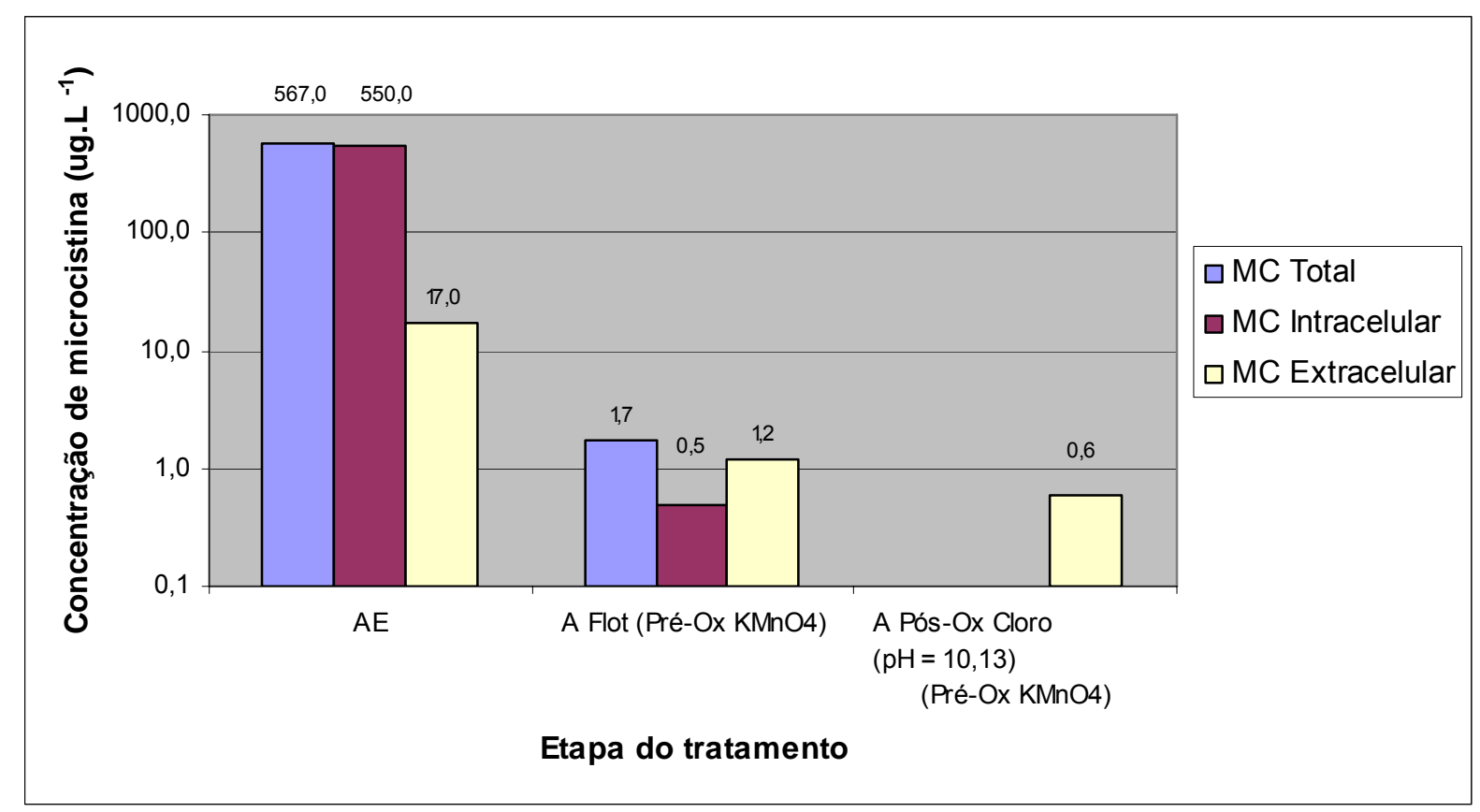

Figura 5.26 - Concentrações remanescentes de microcistina ao longo do fluxograma de tratamento. Nos ensaios de pré-oxidação dosagem de permanganato de 3,0 mg. $\mathrm{L}^{-1}$. Nos ensaios de pós-oxidação dosagem de cloro de 3,0 mg. $\mathrm{L}^{-1}$. 


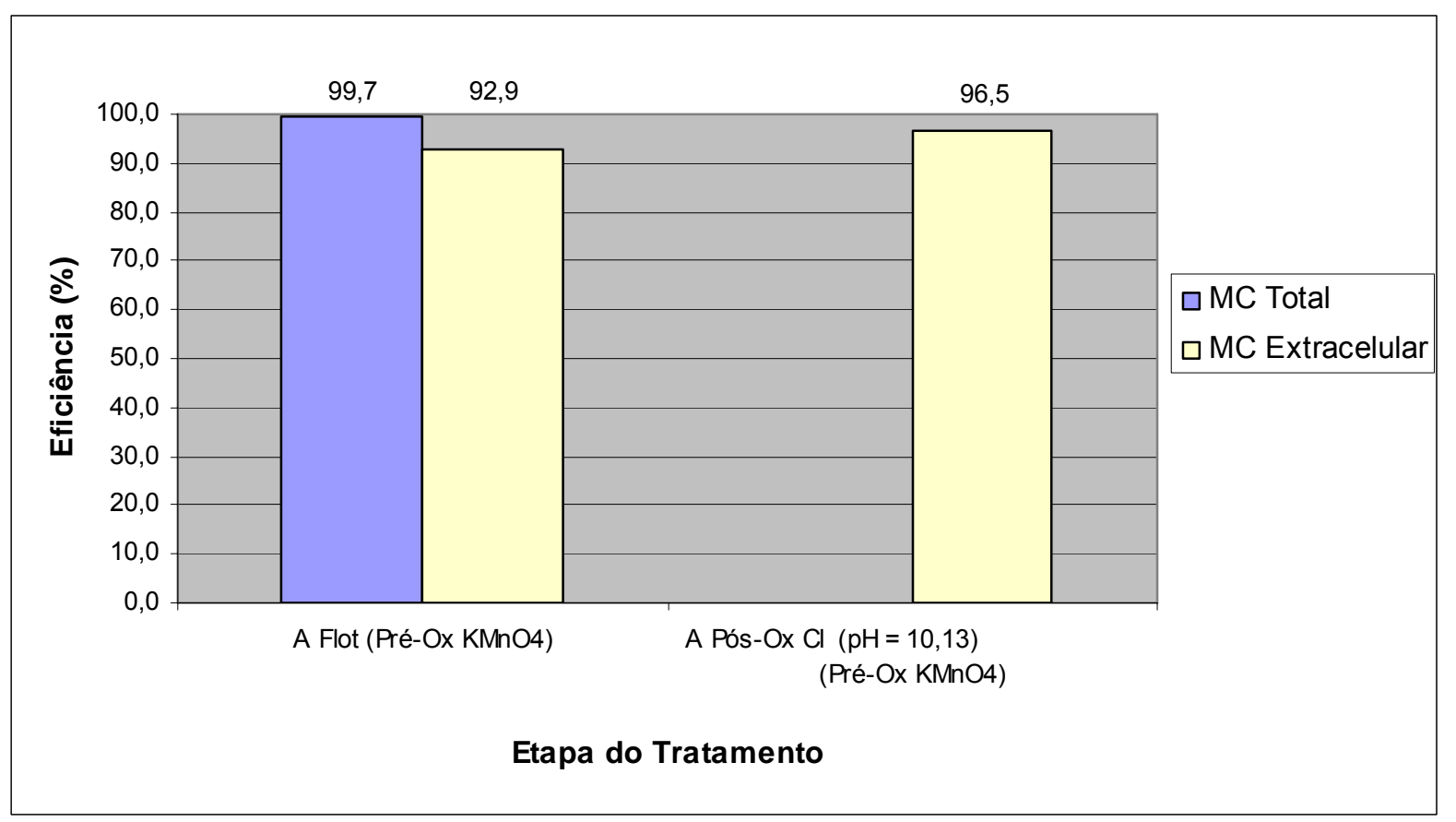

Figura 5.27 - Eficiências de remoção de microcistina ao longo do fluxograma de tratamento. Nos ensaios de pré-oxidação dosagem de permanganato de $3,0 \mathrm{mg} . \mathrm{L}^{-1}$. Nos ensaios de pós-oxidação dosagem de cloro de $3,0 \mathrm{mg} . \mathrm{L}^{-1}$.

Considerando a microcistina total, observa-se que em termos de desempenho de remoção, a etapa de pré-oxidação com permanganato de potássio e flotação apresenta grande eficiência (superior a 99 \%). A flotação incidiu sobre a parcela intracelular que é a mais representativa do montante total, enquanto que a préoxidação com permanganato de potássio contribuiu com a remoção de parte da parcela extracelular.

Quando a análise fica restrita somente à parcela extracelular, a eficiência da préoxidação com permanganato de potássio e flotação é comparativamente menor (cerca de 93\%) e o padrão de potabilidade não é atendido tendo em vista a concentração remanescente de microcistina de $1,2 \mu \mathrm{g} \cdot \mathrm{L}^{-1}$. 
Com a inclusão de mais uma barreira destinada à remoção da microcistina, ou seja, a inclusão da pós-oxidação com cloro da água submetida à flotação, foi observada uma elevação da eficiência da remoção de microcistina extracelular, que passa de cerca de $93 \%$ para $97 \%$. Nessa condição de ensaio o padrão de potabilidade foi atendido com a obtenção de uma concentração remanescente de microcistina na amostra de água pós-oxidada de $0,6 \mu \mathrm{g} \cdot \mathrm{L}^{-1}$.

\section{5 - Pré-Oxidação com Permanganato de Potássio e Cloro Associada à Pós- Oxidação com Cloro}

5.5.1 - ETAPA I - Investigação das Condições de Coagulação da Água de Estudo e Avaliação da Máxima Dosagem Viável de Permanganato de Potássio na Água Bruta

Nesta ETAPA I foi usada a Água de Estudo 4, cujas características qualitativas são apresentadas na tabela 5.24.

Tabela 5.24 - Características Qualitativas de Água de Estudo 4

\begin{tabular}{ccc}
\hline \hline Parâmetro & Valor & Unidade \\
\hline \hline Cor aparente & 940 & $\mathrm{uH}$ \\
\hline Turbidez & 26 & $\mathrm{uT}$ \\
\hline $\mathrm{pH}$ & 7,63 & - \\
\hline $\mathrm{ST}$ & 51 & $\mathrm{mg} . \mathrm{L}^{-1}$ \\
\hline DQO & 136 & $\mathrm{mgO}_{2} \cdot \mathrm{L}^{-1}$ \\
\hline $\mathrm{N}$ amoniacal & 2,81 & $\mathrm{mgN}-\mathrm{NH}_{4} \cdot \mathrm{L}^{-1}$ \\
\hline Absorbância a 254 nm $(*)$ & 0,45 & - \\
\hline Alcalinidade & 111 & $\mathrm{mgCaCO} \cdot \mathrm{L}^{-1}$ \\
\hline Manganês Total & 0,11 & $\mathrm{mgMn} \cdot \mathrm{L}^{-1}$ \\
\hline COT & 27,37 & $\mathrm{mgC} \cdot \mathrm{L}^{-1}$ \\
\hline Microcistina & 14,0 & $\mu g . \mathrm{L}^{-1}$ \\
\hline \hline
\end{tabular}

$\left(^{*}\right)$ - Comprimento do caminho óptico igual a $1,0 \mathrm{~cm}$. 
Após a realização de 8 ensaios de coagulação, floculação e flotação da água de estudo, seguindo o mesmo método dos ensaios anteriores, foram observadas boas condições de tratabilidade com uma dosagem de cloreto férrico de $140 \mathrm{mg}^{-\mathrm{L}^{-1}}$ e pH de coagulação decorrente dessa dosagem de 5,80. Para a finalidade de investigação da pré-oxidação com permanganato de potássio e cloro, todos os ensaios consideraram a aplicação de permanganato de potássio na água de estudo 120 segundos antes da aplicação do cloreto férrico, com dosagem de permanganato de 4,0 mg. $\mathrm{L}^{-1}$, bem como a aplicação de cloro 60 segundos antes da aplicação do cloreto férrico, com dosagem de $2,0 \mathrm{mg} \cdot \mathrm{L}^{-1}$.

Para essas condições de tratabilidade foram obtidos valores de cor aparente e turbidez respectivamente iguais a 56 uH e 0,36 uT, que correspondem a eficiências de remoção de cor de aproximadamente $94 \%$ e de remoção de turbidez de cerca de $99 \%$.

Observa-se que, a exemplo dos ensaios anteriores de pré-oxidação exclusivamente com o permanganato de potássio, a dosagem de cloreto férrico definida nesta etapa é bem superior aos valores encontrados nos ensaios que não consideraram a adição de permanganato de potássio na água de estudo (variação em torno de 60 a 80 $\left.\mathrm{mg} \cdot \mathrm{L}^{-1}\right)$.

Finalizando essa primeira etapa de ensaios foi verificado se a dosagem de 4,0 $\mathrm{mg} \cdot \mathrm{L}^{-1}$ de permanganato de potássio na água de estudo era viável em termos de atendimento dos padrões de potabilidade da água filtrada final, com relação aos parâmetros de controle cor, turbidez e manganês total. A exemplo da inter-oxidação com a associação de permanganato de potássio e cloro, a adição deste último 
contribuiu para viabilizar uma dosagem maior de permanganato de potássio sem o comprometimento da qualidade da água filtrada.

O ensaio de coagulação, floculação e flotação foi repetido com a dosagem de cloreto férrico de $140 \mathrm{mg} \cdot \mathrm{L}^{-1}$ e as dosagens de permanganato e cloro repectivamente iguais a 4,0 mg. $\mathrm{L}^{-1}$ e 2,0 mg. $\mathrm{L}^{-1}$ na água de estudo, sendo que a água filtrada em coluna de areia apresentou os seguintes valores: cor de $13 \mathrm{uH}$, turbidez de 0,12 uT e concentração remanescente de manganês total de $0,05 \mathrm{mg} \cdot \mathrm{L}^{-1}$.

Observa-se que a pré-oxidação com associação do permanganato e cloro contribuiu para a redução da concentração de manganês na água de estudo de 0,11 para 0,05 $\mathrm{mg} \cdot \mathrm{L}^{-1}$. Portanto, foi constatada a viabilidade da dosagem de $4,0 \mathrm{mg} \cdot \mathrm{L}^{-1} \mathrm{de}$ permanganato na água de estudo quando ocorreu a associação com o cloro segundo uma dosagem de 2,0 mg.t-1 . Conseqüentemente, foram adotadas essas dosagens de oxidante para a ETAPA II relativa aos ensaios de oxidação. Na tabela 5.25 são apresentadas as características das águas flotada e filtrada produzidas. 
Tabela 5.25 - Características Qualitativas das Águas Flotada e Filtrada Produzidas nos ensaios de pré-oxidação com a associação de permanganato de potássio e cloro.

\begin{tabular}{|c|c|c|c|}
\hline \multirow[t]{2}{*}{ Parâmetro } & \multicolumn{2}{|c|}{ Valores } & \multirow[t]{2}{*}{ Unidade } \\
\hline & A Flot & A Filt & \\
\hline Cor aparente & 56 & 13 & $\mathrm{uH}$ \\
\hline Turbidez & 0,36 & 0,12 & $\mathrm{uT}$ \\
\hline $\mathrm{pH}$ & 6,58 & 6,70 & - \\
\hline ST & 3 & 2 & mg. $\mathrm{L}^{-1}$ \\
\hline DQO & 35 & 16 & $\mathrm{mgO}_{2} \cdot \mathrm{L}^{-1}$ \\
\hline N Amoniacal & 2,45 & 2,15 & 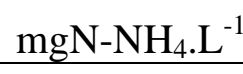 \\
\hline Absorbância a 254 nm (*) & 0,074 & 0,065 & - \\
\hline Alcalinidade & 24 & 13 & $\mathrm{mgCaCO}_{3} \cdot \mathrm{L}^{-1}$ \\
\hline Manganês total & - & 0,05 & $\operatorname{mgMn} \cdot \mathrm{L}^{-1}$ \\
\hline COT & 2,85 & 2,71 & mgC.L ${ }^{-1}$ \\
\hline
\end{tabular}

$(*)$ - Comprimento do caminho óptico igual a $1,0 \mathrm{~cm}$.

5.5.2 - ETAPA II - Ensaios Destinados à Investigação da Remoção de Microcistina Considerando a Máxima Dosagem Viável de Permanganato na Pré-oxidação Associada à Pré-oxidação e Pós-oxidação com Cloro, com Variação de pH

Para esta etapa os ensaios de tratabilidade foram repetidos até a flotação, ou seja: aplicação de permanganato de potássio $\left(4,0 \mathrm{mg} \cdot \mathrm{L}^{-1}\right)$, cloro $\left(2,0 \mathrm{mg} \cdot \mathrm{L}^{-1}\right)$ e cloreto férrico (140 mg. $\left.\mathrm{L}^{-1}\right)$, coagulação, floculação e flotação. Dessa forma, foi produzida pré-oxidada com permanganato de potássio e cloro, posteriormente submetida à flotação e, nesta etapa, submetida à oxidação adicional com cloro segundo uma dosagem de 3,0 mg. $\mathrm{L}^{-1}$. A exemplo dos ensaios do item 5.4.2, a aplicação do cloro foi feita na água submetida à flotação e não na água filtrada com base nas mesmas justificativas apresentadas no referido item. Na tabela 5.26 e nas figuras 5.28 e 5.29 são apresentados os resultados obtidos. 
Tabela 5.26 - Influência da variação do pH na remoção de microcistina, nos ensaios de pré-oxidação com permanganato de potássio e cloro, flotação e pós-oxidação com cloro. Concentração de microcistina na água de estudo de 14,0 $\mathrm{\mu g} \cdot \mathrm{L}^{-1}$.

\begin{tabular}{|c|c|c|c|c|c|c|c|c|}
\hline $\begin{array}{c}\text { Dos. } \\
\mathrm{MnO}_{4}^{-} \\
\text {Água de } \\
\text { estudo } \\
\left(\text { mg.L }^{-1}\right)\end{array}$ & $\begin{array}{c}\text { Dos de } \\
\text { Cloro Água } \\
\text { de estudo } \\
\left(\mathrm{mgCl}_{2} \cdot \mathrm{L}^{-1}\right)\end{array}$ & $\begin{array}{l}\text { Dos. de } \\
\text { Cloro água } \\
\text { filtrada } \\
\left(\mathrm{mgCl}_{2} \cdot \mathrm{L}^{-1}\right)\end{array}$ & $\begin{array}{c}\text { Tempo } \\
\text { Contato } \\
\text { Pós-ox. } \\
\text { (min) }\end{array}$ & pH & $\begin{array}{c}\text { Residual } \\
\mathrm{MnO}_{4}^{-} \\
\left(\mathrm{mg.L} \mathbf{L}^{-1}\right)\end{array}$ & $\begin{array}{c}\text { Residual } \\
\text { Cloro } \\
\left(\mathbf{m g C l}_{2} \cdot \mathrm{L}^{-1}\right)\end{array}$ & $\begin{array}{c}\text { Conc. de } \\
\text { Microcistina } \\
\text { na Água } \\
\text { Oxidada } \\
\left(\mu g . L^{-1}\right) \\
\end{array}$ & $\begin{array}{c}\text { Efic. } \\
\text { Remoção } \\
(\%)\end{array}$ \\
\hline 4,0 & 2,0 & 3,0 & 30 & 3,83 & 0,25 & 1,16 & 0,1 & 99,2 \\
\hline 4,0 & 2,0 & 3,0 & 30 & 6,28 & 0,32 & 1,12 & 0,2 & 98,8 \\
\hline 4,0 & 2,0 & 3,0 & 30 & 7,25 & 0,33 & 1,07 & 0,2 & 98,4 \\
\hline 4,0 & 2,0 & 3,0 & 30 & 8,84 & 0,31 & 1,12 & 2,0 & 85,4 \\
\hline 4,0 & 2,0 & 3,0 & 30 & 10,5 & 0,36 & 1,09 & 3,0 & 78,7 \\
\hline
\end{tabular}

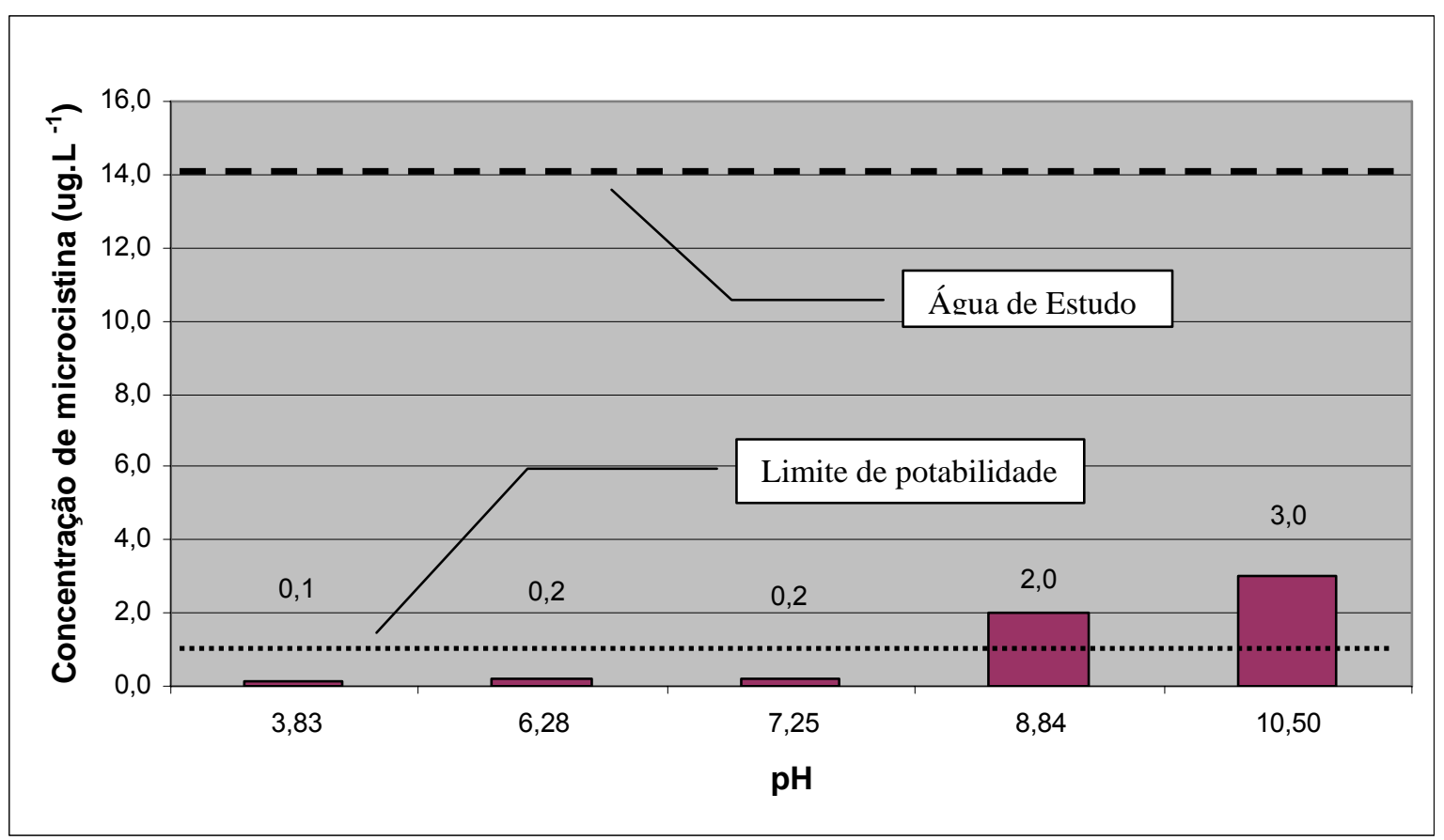

Figura 5.28 - Concentrações remanescentes de Microcistina após a pré-oxidação da água de estudo com permanganato de potássio e cloro e pós-oxidação com cloro. Dosagem de permanganato de 4,0 mg. $\mathrm{L}^{-1}$, dosagem de cloro na pré-oxidação de 2,0 mg. $\mathrm{L}^{-1}$, dosagem de cloro na pós-oxidação de $3,0 \mathrm{mg} . \mathrm{L}^{-1}$ e tempo de contato na pós-oxidação de 30 minutos. 


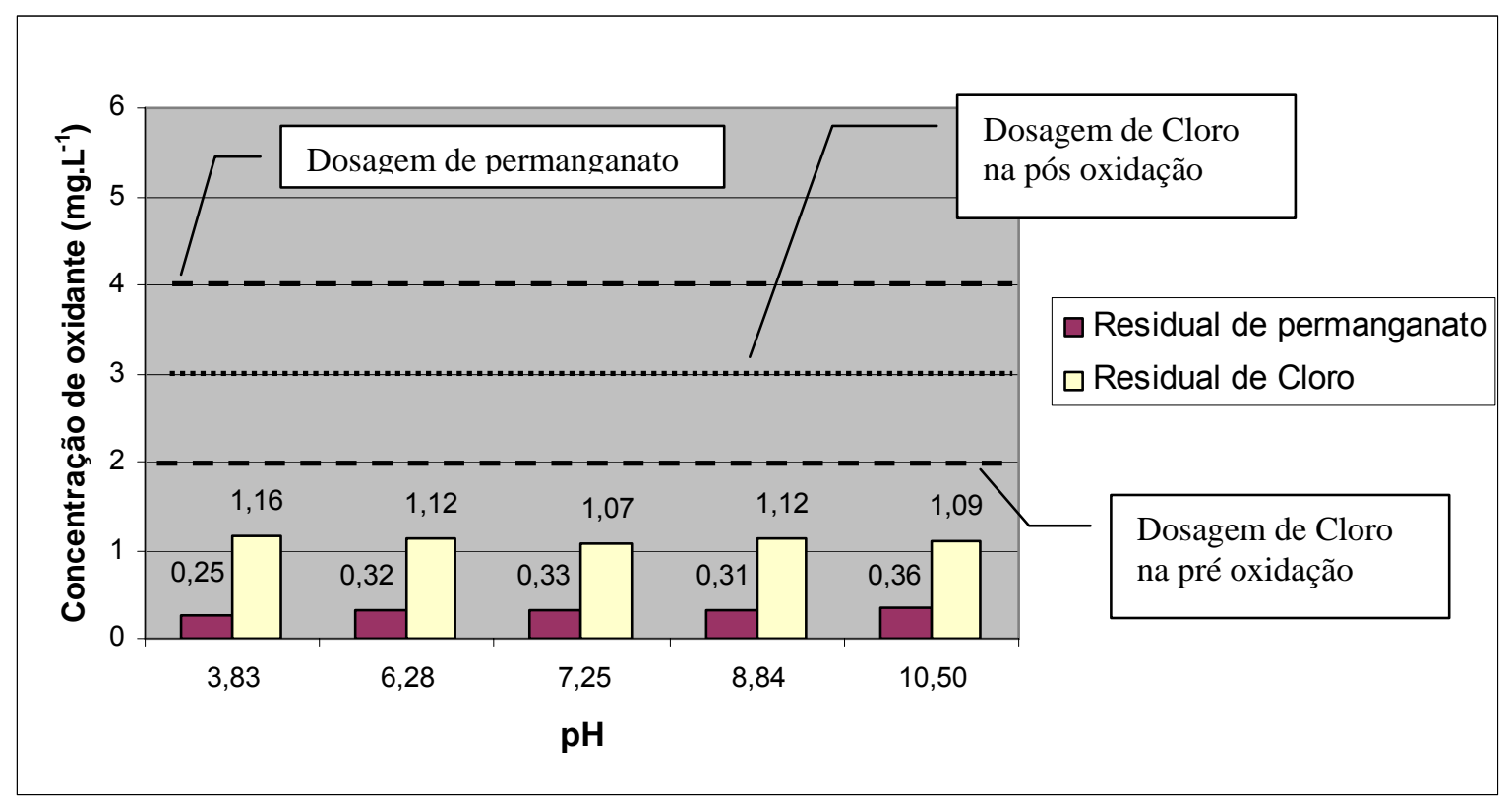

Figura 5.29 - Residuais de permanganato e cloro na água filtrada. Dosagem de permanganato de 4,0 mg. $\mathrm{L}^{-1}$, dosagem de cloro na pré-oxidação de 2,0 mg. $\mathrm{L}^{-1}$, dosagem de cloro na pós-oxidação de $3,0 \mathrm{mg} . \mathrm{L}^{-1}$ e tempo de contato na pós-oxidação de 30 minutos.

Observa-se que a associação da pré-oxidação com permanganato de potássio e cloro e pós oxidação com cloro, segundo as dosagens de oxidantes respectivamente iguais a $4,0 \mathrm{mg} \cdot \mathrm{L}^{-1}$ de permanganato e 2,0 mg.L de cloro na pré-oxidação, bem como 3,0 mg. $\mathrm{L}^{-1}$ de cloro na pós-oxidação, foi efetiva para a remoção da microcistina extracelular para um $\mathrm{pH}$ de pós-oxidação de até 7,25 , com concentração de microcistina abaixo de $0,30 \mathrm{mg} \cdot \mathrm{L}^{-1}$ e eficiências de remoção superiores a $98 \%$.

Comparativamente aos ensaios de pré-oxidação exclusiva com permanganato de potássio e pós-oxidação com cloro, observa-se que no caso da associação do permanganato de potássio e cloro na pré-oxidação o desempenho foi inferior, pois o padrão de potabilidade não foi atendido para toda a faixa de $\mathrm{pH}$ investigada. Isso pode ser justificado por uma pré-oxidação mais enérgica da água de estudo e, 
conseqüentemente, a provável liberação de toxina intracelular para o meio líquido devido a lise celular de parte do fitoplancton.

Ao contrário do que foi observado nos ensaios de oxidação anteriores, não houve tendência de elevação da concentração residual dos oxidantes (permanganato de potássio e cloro) com a elevação dos valores de $\mathrm{pH}$, as concentrações residuais se mantiveram estáveis para toda a faixa de $\mathrm{pH}$ avaliada.

5.5.3 - Considerações Referentes ao Comportamento Global da Remoção da Microcistina nos Diferentes Estágios do Fluxograma de Tratamento

Considerando as concentrações de microcistina na forma extracelular (livre no meio líquido) e total (extracelular e intracelular), que são representadas de forma aproximada pelas amostras submetidas aos ciclos de congelamento e descongelamento, as tabelas 5.27 e 5.28, bem como as figuras 5.30 e 5.31 , apresentam os resultados dos ensaios de pré-oxidação com a associação do permanganato de potássio e cloro e pós-oxidação com cloro. 
Tabela 5.27 - Concentrações de microcistina intracelular e extracelular nos ensaios de pré-oxidação com permanganto de potássio e cloro e pós-oxidação com cloro.

\begin{tabular}{lccc}
\hline \hline \multirow{2}{*}{ Amostra } & \multicolumn{3}{c}{ Concentração de Microcistina ( $\boldsymbol{\mu g . L}^{-\mathbf{1}}$ ) } \\
\cline { 2 - 4 } & Total & Intracelular ( $\left.\mathbf{(}^{\mathbf{1}}\right)$ & Extracelular \\
\hline \hline Água de Barra Bonita & 1,4 & 1,1 & 0,3 \\
\hline Cultura & 2469,0 & 2386,0 & 83,0 \\
\hline Água de Estudo & 358,0 & 344,0 & 14,0 \\
\hline Água pré-oxidada e flotada (2) & 3,0 & -- & 3,0 \\
\hline $\begin{array}{l}\text { Água pré-oxidada, flotada e pós- } \\
\text { oxidada (3) }\end{array}$ & & & 0,2 \\
\hline \hline
\end{tabular}

(1) - Diferença entre a microcistina total e a microcistina extracelular.

(2) - Resultados relativos à dosagem de $\mathrm{MnO}_{4}^{-}$de 4,0 mg. $\mathrm{L}^{-1}$ e $\mathrm{Cl}_{2}$ de 2,0 mg. $\mathrm{L}^{-1}$ na pré-oxidação e flotação da água pré-oxidada.

(3) - Resultado relativo à dosagem de $\mathrm{MnO}_{4}{ }^{-}$de 4,0 mg. $\mathrm{L}^{-1}$ e $\mathrm{Cl}_{2}$ de 2,0 mg. $\mathrm{L}^{-1}$ na pré-oxidação, flotação da água pré-oxidada e pós-oxidação com dosagem de $\mathrm{Cl}_{2}$ de $3,0 \mathrm{mg} . \mathrm{L}^{-1}$, Tc de 30 minutos e pH de 7,25.

Tabela 5.28 - Eficiências de Remoção de Microcistina total e extracelular ao longo do fluxograma de tratamento

\begin{tabular}{ccc}
\hline \hline Etapa do Tratamento & \multicolumn{2}{c}{ Eficiências Acumuladas de Remoção (\%) } \\
\cline { 2 - 3 } & $\begin{array}{c}\text { Base - Microcistina } \\
\text { Total }\end{array}$ & $\begin{array}{c}\text { Base - Parcela } \\
\text { Extracelular }\end{array}$ \\
\hline \hline Pré-oxidação e Flotação (1) & 99,2 & 78,8 \\
\hline Pré-oxidação, flotação e pós-oxidação (2) & - & 98,4 \\
\hline \hline
\end{tabular}

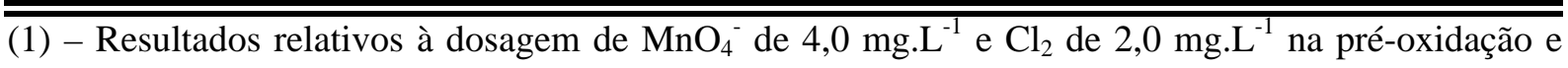
flotação da água pré-oxidada.

(2) - Resultado relativo à dosagem de $\mathrm{MnO}_{4}{ }^{-}$de 4,0 mg.L ${ }^{-1}$ e $\mathrm{Cl}_{2}$ de 2,0 mg.L ${ }^{-1}$ na pré-oxidação, flotação da água pré-oxidada e pós-oxidação com dosagem de $\mathrm{Cl}_{2}$ de $3,0 \mathrm{mg} . \mathrm{L}^{-1}$, Tc de 30 minutos e pH de 7,25. 


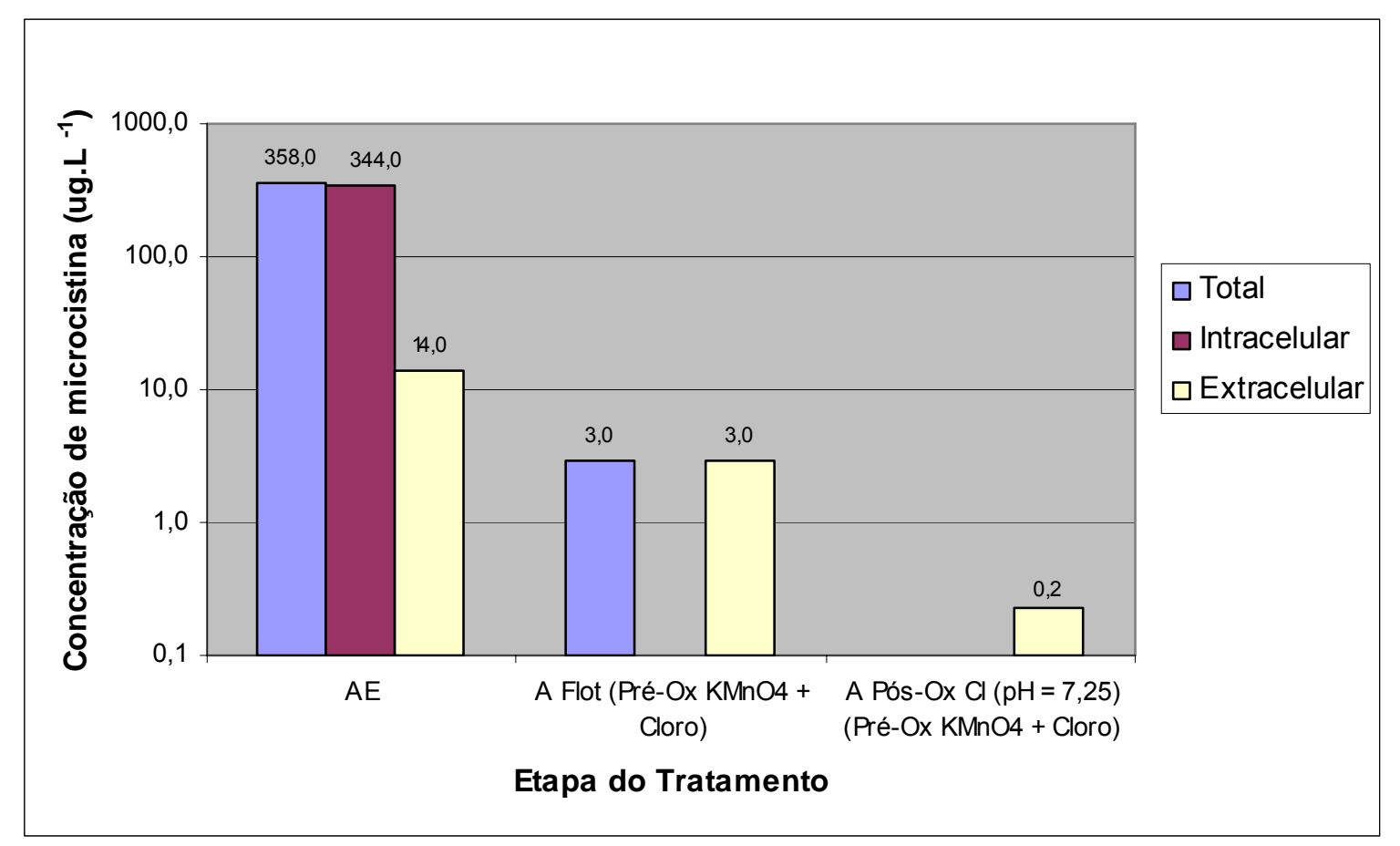

Figura 5.30 - Concentrações Remanescentes de Microcistina ao Longo do Fluxograma de Tratamento. Nos ensaios de pré-oxidação dosagem de permanganato de 4,0 $\mathrm{mg}^{-L^{-1}}$ e cloro de 2,0 mg. $\mathrm{L}^{-1}$. Nos ensaios de pós-oxidação dosagem de cloro de 3,0 mg. $\mathrm{L}^{-1}$.

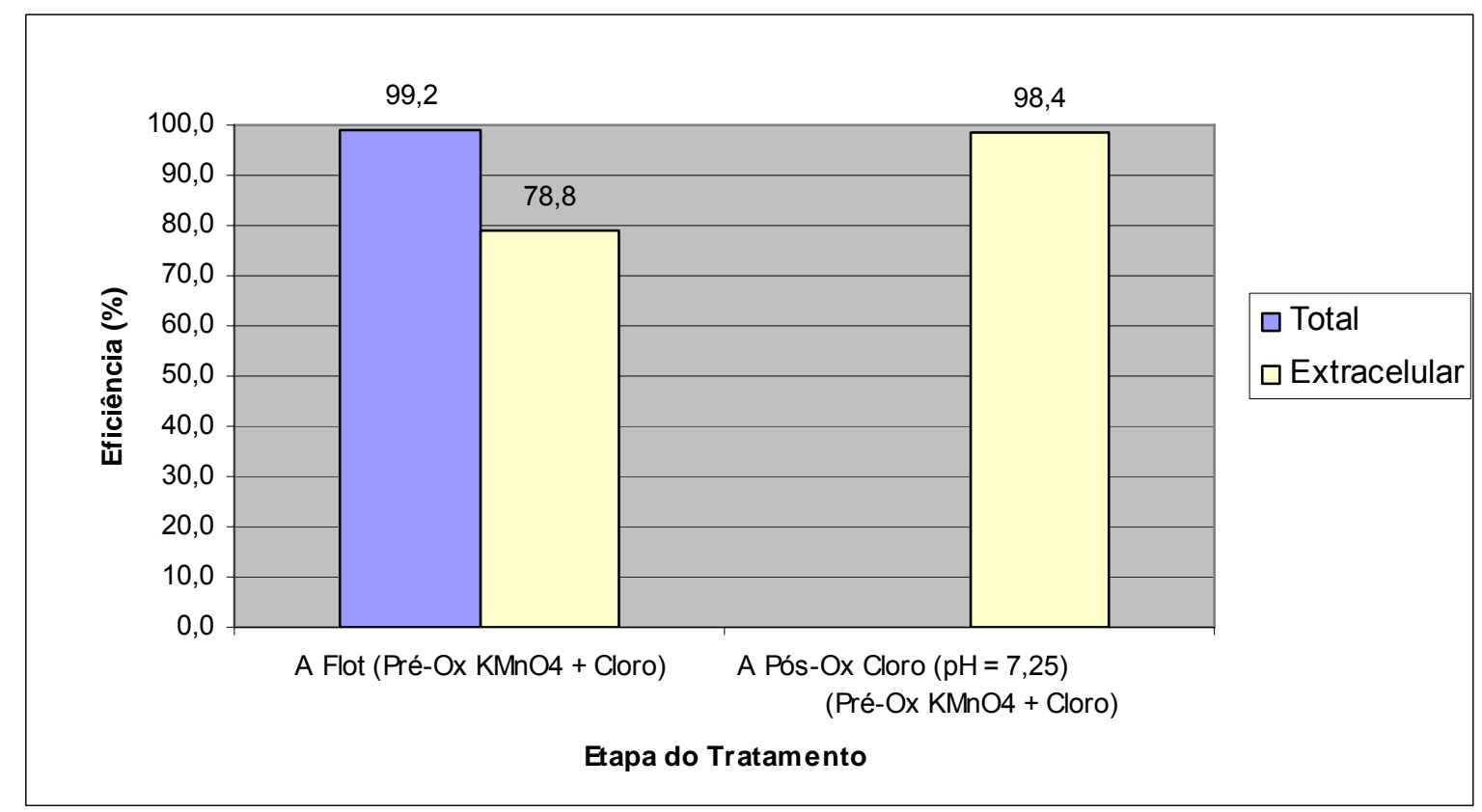

Figura 5.31 - Eficiências de remoção de Microcistina ao Longo do Fluxograma de Tratamento. Nos ensaios de pré-oxidação dosagem de permanganato de 4,0 mg. $\mathrm{L}^{-1}$ e cloro de 2,0 mg. $\mathrm{L}^{-1}$. Nos ensaios de pós-oxidação dosagem de cloro de 3,0 mg. $\mathrm{L}^{-1}$. 
Considerando a microcistina total (soma das parcelas intracelular e extracelular), observa-se que em termos de desempenho de remoção, a etapa de pré-oxidação com a associação de permanganato de potássio e cloro seguida de flotação apresenta grande eficiência (superior a $99 \%$ ), pois a flotação, que é bastante eficiente para a remoção de algas e cianobatérias, incidiu sobre a parcela intracelular que é a mais representativa do montante total de microcistina, enquanto que a pré-oxidação com permanganato de potássio e cloro contribuiu com a remoção de parte da parcela extracelular.

Quando a análise fica restrita somente à parcela extracelular, a eficiência da préoxidação com permanganato de potássio e cloro seguida de flotação é comparativamente menor (cerca de $79 \%$ ) que a condição de pré-oxidação somente com permanganato de potássio seguida de flotação (cerca de $93 \%$ ). Com a associação do cloro na pré-oxidação em conjunto com o permanganato de potássio, provavelmente a oxidação mais enérgica fez com que ocorresse siginificativa lise celular e liberação de microcistina intracelular para o meio líquido, aumentando a parcela de toxina extracelular e, conseqüentemente, contribuindo para a piora de desempenho com relação à sua remoção.

Com a pós-oxidação da água submetida à flotação foi observada uma compensação do baixo desempenho observado no estágio anterior através da elevação da eficiência da remoção de microcistina extracelular, que passa de cerca de 79 \% para cerca de $98 \%$, tendo como base uma água de estudo com concentração original de microcistina extracelular da ordem de $14,0 \mu \mathrm{g} \cdot \mathrm{L}^{-1}$. Novamente observa-se que, com a inclusão de mais uma barreira destinada à remoção da microcistina, o padrão de potabilidade foi atendido com a obtenção de uma concentração remanescente de microcistina na amostra de água pós-oxidada de $0,2 \mu \mathrm{g} \cdot \mathrm{L}^{-1}$. 


\section{6 - Ensaios Complementares}

\subsection{1 - Generalidades}

Conforme citado no item 4.4.7, os ensaios complementares tiveram o objetivo de avaliar todos os fluxogramas de tratamento estudados com relação aos seguintes parâmetros de controle adicionais: carbono orgânico total (COT), $\mathrm{NH}_{4}{ }^{+}$, clorofila - a, contagem e identificação de fitoplancton e trihalometanos.

Esses ensaios complementares foram realizados com a água de estudo 5, sendo que foram necessários novos ensaios com os aparelhos jar-test e flotatest para a definição das melhores condições de tratabilidade em termos de dosagens de cloreto férrico e pH de coagulação. Conforme apresentado na tabela 4.2, as melhores dosagens de cloreto férrico verificadas nos ensaios complementares foram iguais a $55 \mathrm{mg} \cdot \mathrm{L}^{-1}$ nos ensaios que não consideraram a aplicação de permanganato de potássio na água de estudo e $95 \mathrm{mg} \cdot \mathrm{L}^{-1}$ nos demais ensaios. Para essas dosagens de cloreto férrico a água submetida à flotação apresentou valores de cor e turbidez respectivamente na faixa de 8 a $25 \mathrm{uH}$ e 0,38 a $0,50 \mathrm{uT}$, resultando em eficiências de remoção de cor superior a $97 \%$ e de turbidez superior a 99 \%.

A tabela 5.29 apresenta a caracterização da água de estudo 5 utilizada para a realização dos ensaios complementares. 
Tabela 5.29 - Caracterização Qualitativa da Água de Estudo 5

\begin{tabular}{ccc}
\hline \hline Parâmetro & Valor & Unidade \\
\hline \hline Cor aparente & 950 & $\mathrm{uH}$ \\
\hline Turbidez & 100 & $\mathrm{uT}$ \\
\hline $\mathrm{pH}$ & 7,21 & - \\
\hline $\mathrm{DQO}$ & 173 & $\left(\mathrm{mgO}_{2} / \mathrm{l}\right)$ \\
\hline COT & 21,11 & $(\mathrm{mgC} / \mathrm{l})$ \\
\hline Absorbância a $254 \mathrm{~nm}(*)$ & 0,565 & - \\
\hline NH4 & 0,90 & $(\mathrm{mgN}-\mathrm{NH} / \mathrm{l})$ \\
\hline THM & 0,191 & $(\mathrm{mg} / \mathrm{l})$ \\
\hline Clorofila-a & 8,2 & $(\mu \mathrm{l} / \mathrm{l})$ \\
\hline Contagem de células & $2,00 \times 10^{6}$ & $($ células / ml) \\
\hline \hline
\end{tabular}

(*) - Comprimento do caminho óptico igual a $1,0 \mathrm{~cm}$.

Observa-se que a água de estudo 5 apresenta as mesmas características das águas de estudo empregadas nos ensaios anteriores em termos de cor, turbidez e matéria orgânica representada pela DQO e absorbância, sendo que o parâmetro COT, determinado adicionalmente nos ensaios complementares, confirma a elevada presença de matéria orgânica carbonácea, que pode ser justificada pelas características de uso e ocupação do solo da bacia de drenagem do reservatório de Barra Bonita e, consequentemente, o grande aporte de carga poluidora decorrente da intensa atividade antrópica regional. A elevada presença de matéria orgânica também deve ser atribuída à elevada quantidade de fitoplancton existente na cultura preparada no laboratório.

Merece destaque a elevada concentração de trialometanos, cerca do dobro do limite máximo do padrão de potabilidade definido em $0,1 \mathrm{mg} \cdot \mathrm{L}^{-1}$. Essa elevada concentração nas águas superficias talvez possa ser atribuída, em parte, pela 
geração dessas substâncias devido à utilização de produtos a base de cloro para a limpeza e higienização de residências e estabelecimentos industriais e comerciais, com a conseqüente geração de trihalometanos quando tais produtos são incorporados aos esgotos gerados e drenados para as águas do manancial. Observa-se também a possibilidade de geração de trialometanos devido à existência de sistemas de tratamento de esgotos sanitários que adotam técnicas de desinfecção com cloro.

Outra fonte de geração dos trialometanos pode ser a aplicação de cloro na préoxidação e desinfecção nos sistemas produtores de água potável, tendo como água bruta a própria água de Barra Bonita com elevada presença de matéria orgânica, sendo que a água potável produzida com a presença de trialometanos pode ser devolvida para este mesmo manancial na forma de esgotos.

De qualquer forma, a presença de trialometanos nas águas do reservatório de Barra Bonita constitui-se em um grande fator de risco sanitário para as comunidades que porventura venham a explorar suas águas para fins potáveis.

Com relação ao fitoplancton presente na água de estudo, observa-se que a contagem da ordem de $10^{6}$ células por $\mathrm{mL}$ indica condição característica de ambientes com elevada eutrofização. Embora o reservatório de Barra Bonita apresente grande potencial de eutrofização, a elevada contagem de células verificada na água de estudo não pode ser atribuída somente à parcela de água coletada em Barra Bonita, mas, principalmente, à parcela de cultura que foi preparada no laboratório. A figura 5.32 apresenta a contagem e identificação do fitoplancton da água de estudo 5. 


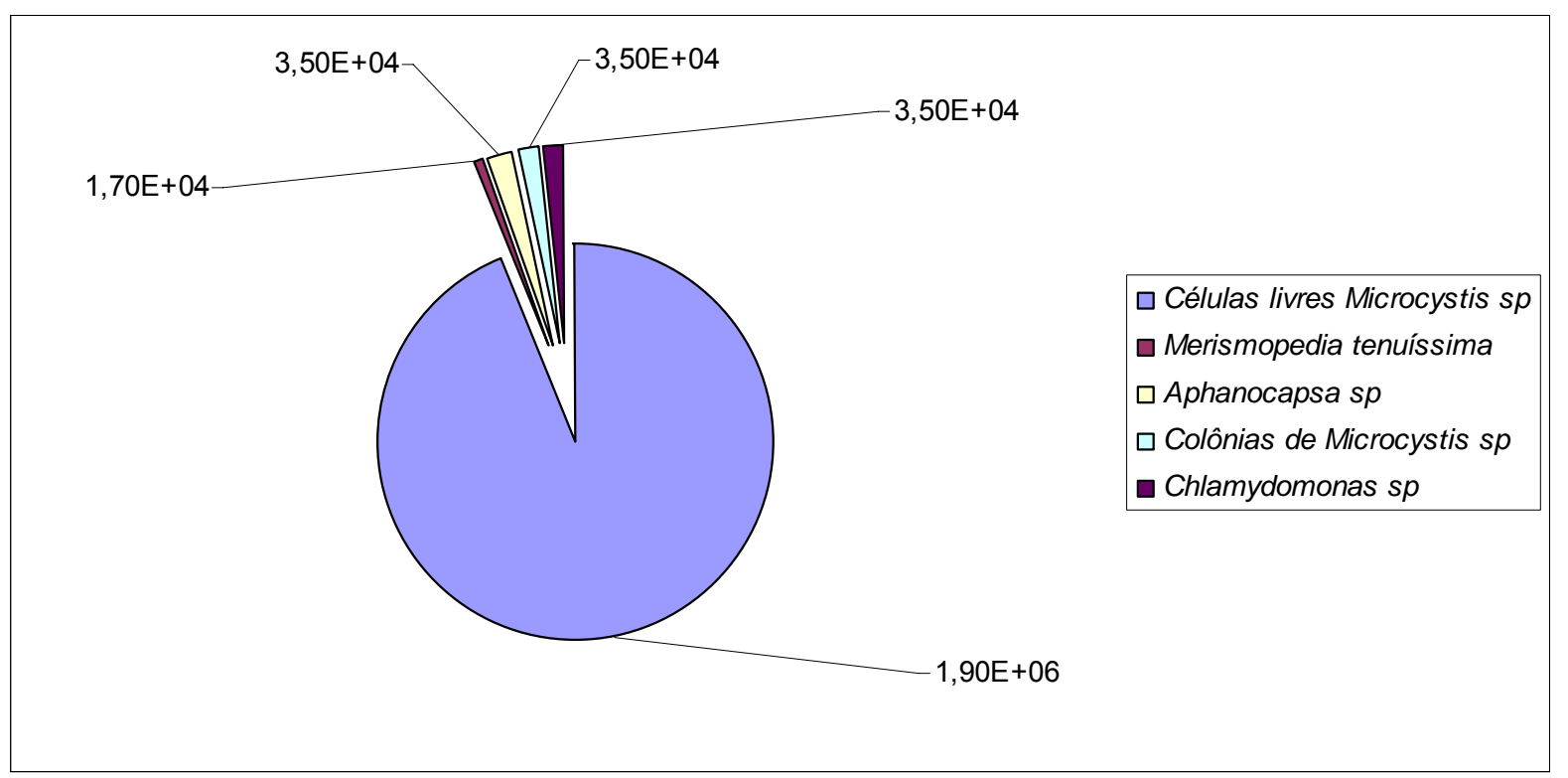

Figura 5.32 - Quantidade e Composição do Fitoplancton da Água de Estudo 5

Observa-se grande predominância de células livres de Microcystis sp (93\%) seguida de uma distribuição praticamente uniforme das cianobactérias Merispopédia tenuíssima, Aphanocapsa, de colônias de Microcystis sp e da clorofícea Chlamydomonas sp.

As células livres e as colônias de Microcystis sp são predominantemente originárias da cultura preparada em laboratório e os outros gêneros de cianobactérias e clorofíceas podem ser atribuídos às águas coletadas no reservatório de Barra Bonita.

5.6.2 - Matéria Orgânica e Trialometanos

\subsubsection{1 - Pós-oxidação com Cloro}

A tabela 5.30 e a figura 5.33 apresentam o comportamento observado nos ensaios de pós-oxidação com cloro na remoção da matéria orgânica e na remoção ou formação dos trihalometanos. 
Tabela 5.30 - Matéria orgânica e trihalometanos nos ensaios de pós-oxidação com Cloro. Dosagem de cloro de 7,0 $\mathrm{mg} \cdot \mathrm{L}^{-1}$.

\begin{tabular}{lccccc}
\hline \hline Parâmetros & Unidade & $\begin{array}{c}\text { Água de } \\
\text { Estudo }\end{array}$ & A Flot & A Flot/Filt & $\begin{array}{c}\text { Água Filtrada e } \\
\text { Pós-Oxidada } \\
\text { com Cloro }\end{array}$ \\
\hline \hline $\mathrm{COT}$ & $\left(\mathrm{mgC.L}{ }^{-1}\right)$ & 21,11 & 3,84 & 3,52 & 3,48 \\
\hline $\mathrm{ABS}_{254}\left(^{*}\right)$ & - & 0,565 & 0,132 & 0,095 & 0,107 \\
\hline $\mathrm{NH}_{4}^{+}$ & $\left(\mathrm{mgN}^{+} \mathrm{NH}_{4}^{+} \cdot \mathrm{L}^{-1}\right)$ & 0,90 & 0,18 & 0,36 & 0 \\
$\mathrm{THM}$ & $\left(\mathrm{mg} \cdot \mathrm{L}^{-1}\right)$ & 0,191 & - & - & 0,146 \\
\hline \hline
\end{tabular}

$(*)-$ Comprimento do caminho óptico igual a 1,0 cm.

Observa-se que a flotação resultou em grande remoção da matéria orgânica, tanto de origem carbonácea quanto amoniacal, sendo que nas etapas subseqüentes de filtração e pós-oxidação essa remoção continuou a existir, mas de forma menos intensa já que as concentrações remanescentes de matéria orgânica na amostra de água submetida à flotação foram relativamente bem menores que as verificadas na água de estudo.

Foi observada elevação na concentração de nitrogênio amoniacal na água filtrada, sendo que esse valor parece ser, a princípio, incoerente e pode ser descartado da presente análise. Entretanto, foi observada remoção praticamente total do nitrogênio amoniacal com a oxidação da água filtrada, com a aplicação de cloro segundo dosagem de cloro ativo de 7,0 mg. $\mathrm{L}^{-1}$, que é um resultado coerente devido a elevada dosagem de oxidante.

Com relação aos trialometanos, ao contrário do esperado, foi observada uma remoção parcial dessas substâncias, mesmo com a aplicação de cloro. Esse comportamento a princípio mostra-se incoerente, porém observa-se que a etapa de flotação pode ter sido responsável pela remoção parcial dos trihalometanos devido ao efeito de "stripping" inerente a esse processo de separação de fases. 
Devido a grande volatilidade dos trihalometanos, a sua remoção parcial por stripping parece ser viável. LIN \& HOANG (2001) observaram que a inalação dos THM volatilizados nas atividades domésticas de banho e preparo de alimentos é comparável a ingestão direta dos mesmos, confirmando a grande volatilidade desses compostos e, consequentemente, a possibilidade de sua remoção por stripping. Outro indício da volatilidade dos THM são os cuidados necessários para a preservação das amostras destinadas à determinação analítica dos mesmos. Entre os procedimentos de conservação dessas amostras é fortemente recomendado que os frascos sejam totalmente cheios e fechados com tampa apropriada para evitar a existência de bolhas de ar, de forma a eliminar a possibilidade de volatilização dos THM para a fase gasosa.

Segundo PÁDUA \& FERREIRA (2004), a remoção de THM foi superior a $60 \%$ após períodos de aeração de amostras de água filtrada superiores a 15 minutos. A aeração das amostras foi obtida pela mistura (gradiente de velocidade superior a $600 \mathrm{~s}^{-1}$ ) das mesmas em equipamento de Jar-test. Esses pesquisadores concluíram que a aeração pode ser um processo viável para a remoção dos THM, que é diferenciada dependendo da volatilidade de cada composto individual.

Portanto, no presente estudo a introdução de água saturada com ar durante o processo de flotação pode ter causado efeito de "stripping" similar ao causado pela aeração estudada por PÁDUA e FERREIRA (2004). Embora na flotação a expansão do ar, oriundo da parcela de recirculação de água saturada, tenha ocorrido em período inferior a cinco minutos, ou seja, bem inferior ao período de aeração bem sucedido de 15 minutos verificado pelos citados pesquisadores, a intensa aeração e agitação causada pelas microbolhas características do processo de flotação pode ter compensado o menor tempo de contato do ar com a amostra. 

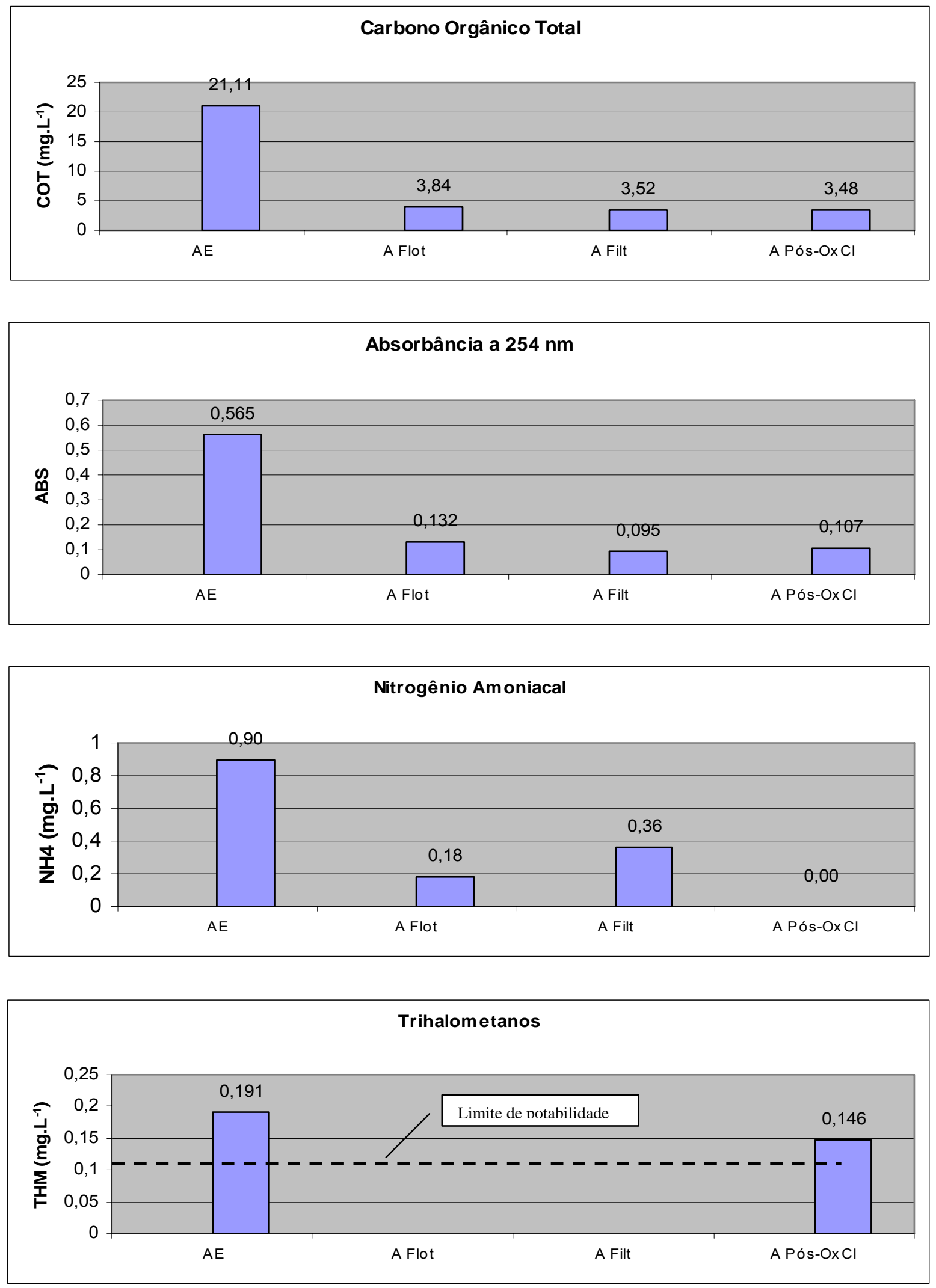

Figura 5.33 - Matéria orgânica e trihalometanos nos ensaios de pós-oxidação com cloro. Dosagem de cloro de 7,0 mg/l. 
Infelizmente, objetivando redução de custos, as determinação analíticas de trialometanos ficaram restritas às amostras submetidas a dosagem de cloro e, portanto, no fluxograma de tratamento estudado não foram determinados os trialometanos nas amostras de água submetida à flotação e filtrada, impedindo a confirmação da remoção de trialometanos na flotação.

$\mathrm{Na}$ água pós-oxidada, que se constitui no resultado final desse fluxograma de tratamento, foi observada concentração de trialometanos de $0,146 \mathrm{mg} \cdot \mathrm{L}^{-1}$ que, embora seja menor que a concentração verificada na água de estudo, ainda é maior que o limite definido no padrão de potabilidade igual a $0,1 \mathrm{mg} \cdot \mathrm{L}^{-1}$. Portanto, tendo em vista os resultados obtidos presume-se que ao longo do fluxograma de tratamento ocorreu inicialmente uma remoção de trihalometanos na etapa de flotação e, posteriormente, a formação de trialometanos após a aplicação de cloro na água filtrada, pois havia matéria orgânica remanescente (cerca de $3,5 \mathrm{mg} \cdot \mathrm{L}^{-1}$ de COT) para a reação com o cloro aplicado na água filtrada.

No balanço geral entre remoção e formação, ocorreu redução dos THM, mas insuficiente para o atendimento do padrão de potabilidade. Entretanto, é possível observar que o não atendimento do padrão de potabilidade talvez possa ser atribuído à característica inicial da água de estudo, pois se esta apresentasse menor concentração de trialometanos, o atendimento desse padrão poderia ser possível, mesmo para a elevada dosagem de cloro, de $7,0 \mathrm{mg} \cdot \mathrm{L}^{-1}$, que foi empregada nos ensaios de pós-oxidação. 
5.6.2.2 - Inter-oxidação com Permanganato de Potássio e Inter-oxidação com a Associação de Permanganato de Potássio e Cloro

A tabela 5.31 e a figura 5.34 apresentam o resultados observados nos ensaios de inter-oxidação com permanganato de potássio e de inter-oxidação com a associação de permanganato de potássio e cloro na remoção da matéria orgânica e na remoção ou formação dos trialometanos.

Tabela 5.31 - Matéria orgânica e trihalometanos nos ensaios de inter-oxidação com permanganato de potássio (dosagem de $0,2 \mathrm{mg} . \mathrm{L}^{-1}$ ) e de inter-oxidação com a associação de permanganato de potássio e cloro (dosagem de permanganato de $0,3 \mathrm{mg}^{-1} \mathrm{~L}^{-1}$ e cloro de

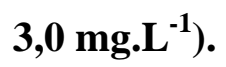

\begin{tabular}{|c|c|c|c|c|}
\hline \multirow[t]{2}{*}{ Parâmetros } & \multirow[t]{2}{*}{ Unidade } & \multirow[t]{2}{*}{ Água de Estudo } & \multicolumn{2}{|c|}{ A Flot } \\
\hline & & & $\begin{array}{l}\text { Inter-ox } \\
\mathrm{KMnO}_{4} \\
\end{array}$ & $\begin{array}{c}\text { Inter-ox } \\
\mathrm{KMnO}_{4}+\mathrm{Cl} \\
\end{array}$ \\
\hline $\mathrm{COT}$ & $\left(\mathrm{mgC} . \mathrm{L}^{-1}\right)$ & 21,11 & 3,20 & 3,94 \\
\hline $\mathrm{ABS}_{254}(*)$ & - & 0,565 & 0,065 & 0,098 \\
\hline $\mathrm{NH}_{4}^{+}$ & $\left(\mathrm{mgN}-\mathrm{NH}_{4}{ }^{+} \cdot \mathrm{L}^{-1}\right)$ & 0,90 & 0,54 & 0,36 \\
\hline THM & $\left(\mathrm{mg} . \mathrm{L}^{-1}\right)$ & 0,191 & - & 0,125 \\
\hline
\end{tabular}

(*) - Comprimento do caminho óptico igual a $1,0 \mathrm{~cm}$.

A exemplo dos ensaios de pós-oxidação com cloro, nos ensaios de inter-oxidação a flotação resultou em grande remoção da matéria orgânica, tanto de origem carbonácea quanto amoniacal. Na etapa subseqüente de inter-oxidação com permanganato de potássio, de forma isolada ou associada ao cloro, a remoção continuou a existir, mas de forma menos intensa, já que as concentrações remanescentes de matéria orgânica na amostra de água submetida à flotação foram relativamente pequenas. 

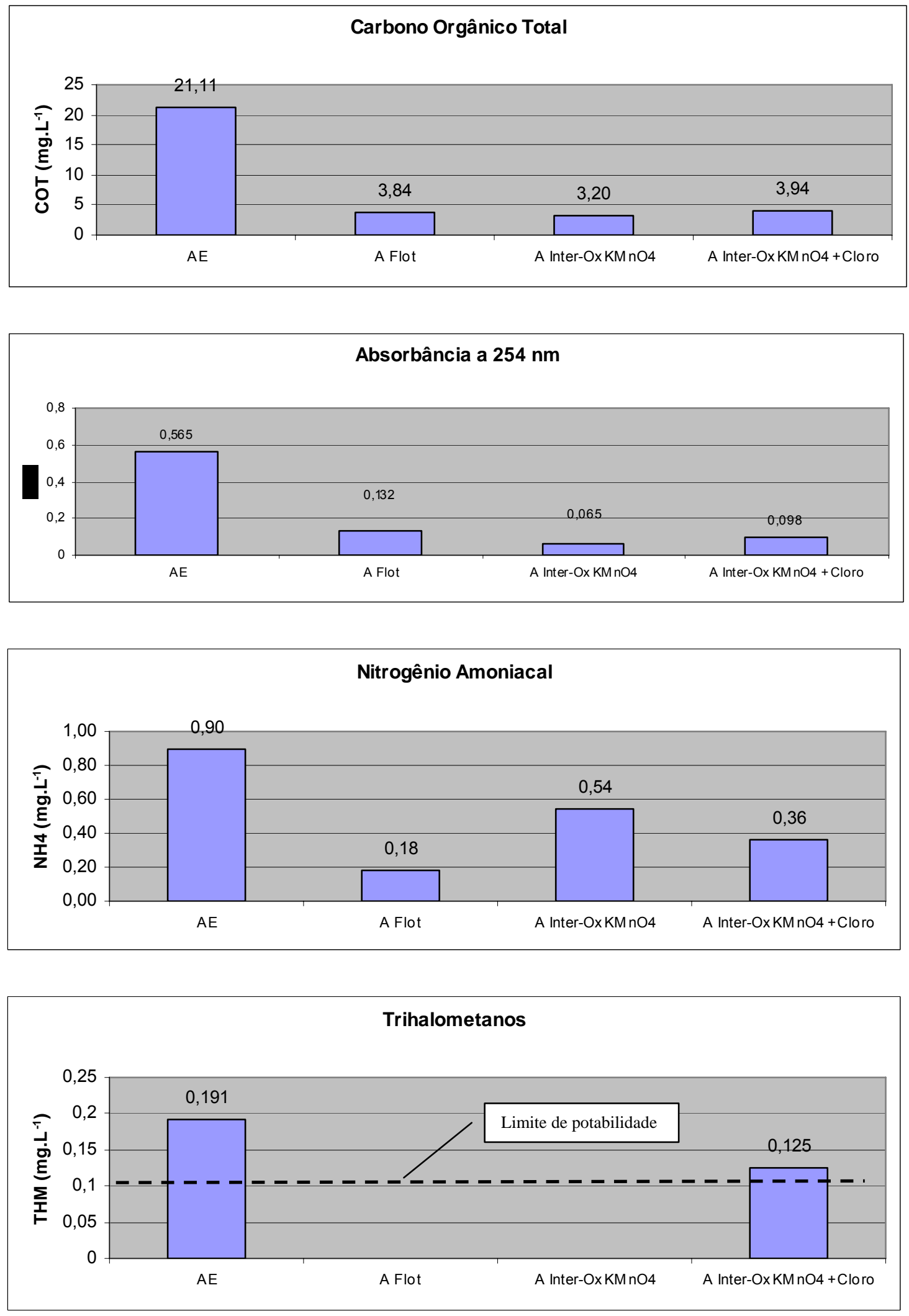

Figura 5.34 - Matéria orgânica e trialometanos nos ensaios de inter-oxidação com permanganato de potássio $\left(\mathrm{MnO}_{4}{ }^{-}\right.$de $\left.0,2 \mathrm{mg} / \mathrm{l}\right)$ e com a associação de permanganato de potássio (dosagem de $\mathrm{MnO}_{4}^{-}$de 0,3 mg/l) e Cloro (dosagem de $\mathrm{Cl}_{2}$ de 3,0 mg/l) 
Com relação aos trialometanos, novamente observa-se balanço favorável entre a remoção por "stripping" na etapa de flotação e a formação devido à aplicação do cloro na inter-oxidação. Entretanto, em termos comparativos, observa-se que na água submetida à flotação e oxidada com permanganato de potássio e cloro a concentração de THM foi menor quando comparada com a água filtrada e oxidada apenas com cloro $\left(0,125 \mathrm{mg} \cdot \mathrm{L}^{-1}\right.$ contra $\left.0,146 \mathrm{mg} \cdot \mathrm{L}^{-1}\right)$.

Embora a diferença entre as concentrações de THM apresentadas no parágrafo anterior seja pouco siginificativa, os resultados obtidos sugerem uma maior geração de THM no caso da inter-oxidação com a aplicação exclusiva do cloro, sendo que isso pode ser atribuído a dois fatores: o primeiro relativo à menor dosagem de cloro ativo no caso da inter-oxidação (3,0 mg/l contra $7,0 \mathrm{mg} / \mathrm{l}$ na pós oxidação); o segundo devido ao fato de que o permanganato de potássio não gera THM devido à reação com a matéria orgânica (EPA - 1999).

No balanço entre remoção de THM devido à flotação, e formação de THM devido à aplicação do cloro, o resultado global foi melhor quando comparado com o fluxograma de pós-oxidação com cloro, embora a concentração remanescente de THM tenha sido, "em termos práticos", maior que o limite definido no padrão de potabilidade.

A rigor, é importante observar que se forem considerados os algarismos significativos do limite de THM estabelecido na Portaria $518\left(0,1 \mathrm{mg} \cdot \mathrm{L}^{-1}\right)$, as concentrações remanescente de THM iguais a 0,125 e 0,146 mg. $\mathrm{L}^{-1}$ atendem ao padrão de potabilidade, embora no presente estudo seja assumido, em termos práticos e a favor da segurança, que as concentrações remanescentes verificadas não sejam valores adequados em termos de potabilização da água. 


\subsubsection{3 - Pré-oxidação com Permanganato de Potássio e Pós-oxidação com Cloro}

A tabela 5.32 e a figura 5.35 apresentam os resultados dos ensaios de pré-oxidação com permanganato de potássio e pós-oxidação com cloro na remoção da matéria orgânica e na remoção ou formação dos trialometanos.

Tabela 5.32 - Matéria orgânica e trihalometanos nos ensaios de pré-oxidação com permanganato de potássio (dosagem de permanganato de $3,0 \mathrm{mg} . \mathrm{L}^{-1}$ ) e pós-oxidação com cloro (dosagens de cloro de 3,0 e 7,0 mg. $\mathrm{L}^{-1}$ ).

\begin{tabular}{|c|c|c|c|c|c|}
\hline \multirow[t]{2}{*}{ Parâmetros } & \multirow[b]{2}{*}{ Unidade } & \multirow{2}{*}{$\begin{array}{l}\text { Água de } \\
\text { Estudo }\end{array}$} & \multicolumn{3}{|c|}{ A Flot } \\
\hline & & & $\begin{array}{c}\text { Pré-ox } \\
\text { KMnO4 } \\
\text { (1) }\end{array}$ & $\begin{array}{c}\text { Pré-ox KMnO4 } \\
\text { Pós-ox Cl } \\
(3,0 \text { mg/l) (2) }\end{array}$ & $\begin{array}{c}\text { Pré-ox KMnO4 } \\
\text { Pós-ox Cl } \\
\text { (7,0 mg/l) (2) }\end{array}$ \\
\hline COT & $\left(\mathrm{mgC.L} \mathrm{L}^{-1}\right)$ & 21,11 & 3,20 & 2,60 & 2,41 \\
\hline $\mathrm{ABS}_{254}(3)$ & - & 0,565 & 0,065 & 0,060 & 0,053 \\
\hline $\mathrm{NH}_{4}^{+}$ & $\left(\mathrm{mgN}-\mathrm{NH}_{4}^{+} \cdot \mathrm{L}^{-1}\right)$ & 0,90 & 0,54 & 0,18 & ND \\
\hline THM & $\left(\mathrm{mg} . \mathrm{L}^{-1}\right)$ & 0,191 & - & 0,073 & 0,127 \\
\hline
\end{tabular}

ND - Não detectado

(1) - Ensaio de pré-oxidação com $\mathrm{KMnO}_{4}$ da água de estudo e flotação da água pré-oxidada.

(2) - Ensaio de pré-oxidação com $\mathrm{KMnO}_{4}$ da água de estudo, flotação da água pré-oxidada e pós-oxidação com cloro (dosagens de 3,0 e 7,0 mg. $\mathrm{L}^{-1}$ ).

(3) - Comprimento do caminho óptico igual a $1,0 \mathrm{~cm}$.

Como neste fluxograma de tratamento ocorre a pré-oxidação com permanganato de potássio, observa-se que os teores de matéria orgânica carbonácea na água submetida à flotação são ainda menores quando comparado com outros fluxogramas de tratamento que não consideram a pré-oxidação (COT e ABS respectivamente iguais a 3,84 e $0,132 \mathrm{mg}^{-\mathrm{L}^{-1}}$ na água submetida à flotação sem préoxidação e COT e ABS respectivamente iguais a 3,20 e 0,065 mg. $\mathrm{L}^{-1}$ na água préoxidada e submetida à flotação). 

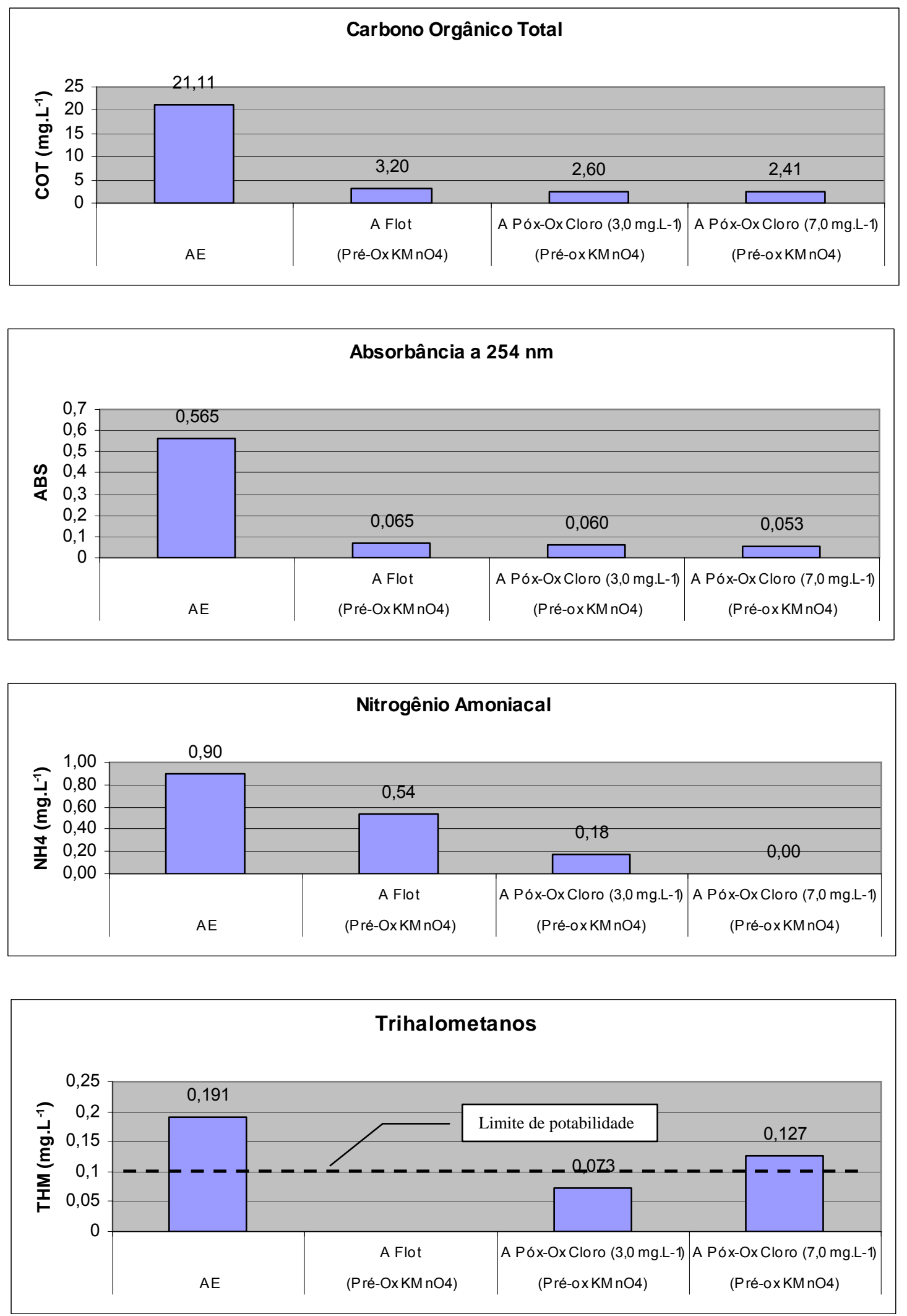

Figura 5.35 - Matéria orgânica e trialometanos nos ensaios de pré-oxidação com permanganato de potássio (dosagem de $\mathrm{MnO}_{4}^{-}$de $3,0 \mathrm{mg} . \mathrm{L}^{-1}$ ) e pós-oxidação com cloro (dosagens de $\mathrm{Cl}_{2}$ de 3,0 e 7,0 mg. $\mathrm{L}^{-1}$ ) 
A aplicação de cloro na água submetida à flotação, simulando a pós-oxidação, resulta em redução da concentração de matéria orgânica, que é acentuada com o aumento da dosagem de cloro devido à oxidação.

Com relação ao nitrogênio amoniacal, os resultados estão coerentes neste fluxograma de tratamento, com a gradual redução de concentração nas etapas de pré-oxidação, flotação e pós-oxidação com cloro segundo as dosagens de cloro ativo aplicadas.

Com relação aos trialometanos, novamente observa-se balanço favorável entre a remoção por "stripping" na etapa de floculação e a formação devido à aplicação do cloro na pós-oxidação.

Para a condição de pós-oxidação com cloro segundo dosagem de cloro ativo de 3,0 $\mathrm{mg} \cdot \mathrm{L}^{-1}$, observa-se que a concentração remanescente de trialometanos na água pósoxidada resultou em valor menor que o limite do padrão de potabilidade, indicando, portanto, que o balanço entre remoção e formação dos THM foi favorável nessa condição de ensaio. O bom resultado obtido pode ser atribuído a dois fatores: a préoxidação com o permanganto de potássio e, conseqüentemente, a remoção inicial de matéria orgânica sem formação de THM's (ao contrário do que ocorreria se o oxidante fosse o cloro) e a menor dosagem de cloro ativo na etapa de pós-oxidação (apenas 3,0 mg.L $\mathrm{L}^{-1}$ ).

Entretanto, para a condição de pós-oxidação com cloro segundo dosagem de cloro ativo de $7,0 \mathrm{mg} \cdot \mathrm{L}^{-1}$, observa-se que a concentração remanescente de trihalometanos na água pós-oxidada resultou em valor maior que o limite do padrão de potabilidade, indicando, portanto, que o balanço entre remoção e formação dos THM não foi benéfico nessa condição de ensaio. O pior resultado obtido pode ser atribuído à 
maior dosagem de cloro na etapa de pós-oxidação e, conseqüentemente, a maior formação de THM devido a reação com a matéria orgânica remanescente na água submetida à flotação.

Portanto, presume-se que a associação da pré-oxidação do permanganato de potássio com a pós-oxidação com cloro resultou em uma concentração final de THM abaixo do limite do padrão de potabilidade, desde que a dosagem de cloro na pós oxidação não seja elevada. Caso contrário, mesmo considerando o efeito benéfico da associação com o permanganato de potássio na pré-oxidação, para dosagens mais elevadas de cloro na pós-oxidação haverá maior formação de THM e, conseqüentemente, a probabilidade de não atender o padrão de potabilidade será maior. 
5.6.2.4 - Pré-oxidação com a Associação de Permanganato de Potássio e Cloro e Pós-oxidação com Cloro

A tabela 5.33 e a figura 5.36 apresentam os resultados dos ensaios de pré-oxidação com a associação do permanganato de potássio e cloro e pós-oxidação com cloro na remoção da matéria orgânica e na remoção ou formação dos trialometanos.

Tabela 5.33 - Matéria orgânica e trihalometanos nos ensaios de pré-oxidação com a associação do permanganato de potássio (dosagem de permanganato de $4,0 \mathrm{mg} . \mathrm{L}^{-1}$ ) e cloro (dosagem de 2,0 mg.L $\mathrm{L}^{-1}$ ) e pós-oxidação com cloro (dosagem de 3,0 mg.L $\mathrm{L}^{-1}$ ).

\begin{tabular}{lcccc}
\hline \hline Parâmetros & Unidade & $\begin{array}{c}\text { Água de } \\
\text { estudo }\end{array}$ & $\begin{array}{c}\text { A Flot } \\
\text { Pré-ox KMnO } \\
\text { (1) }\end{array}$ & $\begin{array}{c}\text { Água Pós-oxidada } \\
\text { Pré-ox KMnO } \\
\text { Pós-ox Cl (2) }\end{array}$ \\
\hline \hline $\mathrm{COT}$ & $\left(\mathrm{mgC.L}^{-1}\right)$ & 21,11 & 3,25 & 3,55 \\
\hline $\mathrm{ABS}_{254}(3)$ & - & 0,565 & 0,065 & 0,046 \\
$\mathrm{NH}_{4}^{+}$ & $\left(\mathrm{mgN}^{+} \mathrm{NH}_{4}{ }^{+} / \mathrm{L}\right)$ & 0,90 & 0,36 & 0,00 \\
\hline $\mathrm{THM}$ & $\left(\mathrm{mg} . \mathrm{L}^{-1}\right)$ & 0,191 & 0,024 & 0,087 \\
\hline \hline
\end{tabular}

(1) - Ensaio de pré-oxidação com a associação de $\mathrm{KMnO}_{4}$ e Cl da água de estudo e flotação da água pré-oxidada.

(2) - Ensaio de pré-oxidação com a associação de $\mathrm{KMnO}_{4}$ e $\mathrm{Cl}$ da água de estudo, flotação da água pré-oxidada e pós-oxidação com cloro.

(3) - Comprimento do caminho óptico igual a 1,0 cm.

A exemplo dos outros ensaios, a flotação resultou em uma grande remoção da matéria orgânica, tanto de origem carbonácea quanto amoniacal. Neste fluxograma de tratamento observa-se que o teor de matéria orgânica carbonácea na água submetida à flotação é semelhante ao verificado no fluxograma que considera a préoxidação somente com o permanganato de potássio. 
Com relação à concentração de nitrogênio amoniacal na água pré-oxidada com $\mathrm{KMnO}_{4}$ e cloro e, na seqüência, flotada, observa-se que o valor obtido é menor que o verificado na água pré-oxidada somente com $\mathrm{KMnO}_{4}$ e flotada, indicando, portanto, que a oxidação mais enérgica obtida com a associação dos dois oxidantes resultou em menor concentração remanescente de nitrogênio amoniacal $\left(0,36 \mathrm{mg} \cdot \mathrm{L}^{-1}\right.$ comparado com $0,54 \mathrm{mg} \cdot \mathrm{L}^{-1}$ no fluxograma de pré-oxidação com $\mathrm{KMnO}_{4}$ ).

Com relação aos trialometanos, nesse fluxograma de tratamento também foram verificados indícios do efeito positivo da remoção por "stripping" na etapa de flotação e tornou-se evidente o efeito negativo de formação de THM na pós oxidação com cloro, pois ocorreu elevação da concentração dos THM após a aplicação do cloro na água submetida à flotação (pós-oxidação) segundo a dosagem de cloro ativo de 3,0 $\mathrm{mg} \cdot \mathrm{L}^{-1}$ (THM na água pré-oxidada e flotada $=0,024 \mathrm{mg} \cdot \mathrm{L}^{-1} \mathrm{e}$ THM na água pósoxidada de $\left.0,087 \mathrm{mg} \cdot \mathrm{L}^{-1}\right)$.

Mesmo considerando o evidente efeito negativo da formação de THM na pósoxidação com cloro, a concentração remanescente de trihalometanos na água pósoxidada resultou em valor menor que o limite do padrão de potabilidade, indicando, portanto, que o balanço entre remoção e formação dos THM também foi favorável nessa condição de ensaio. 

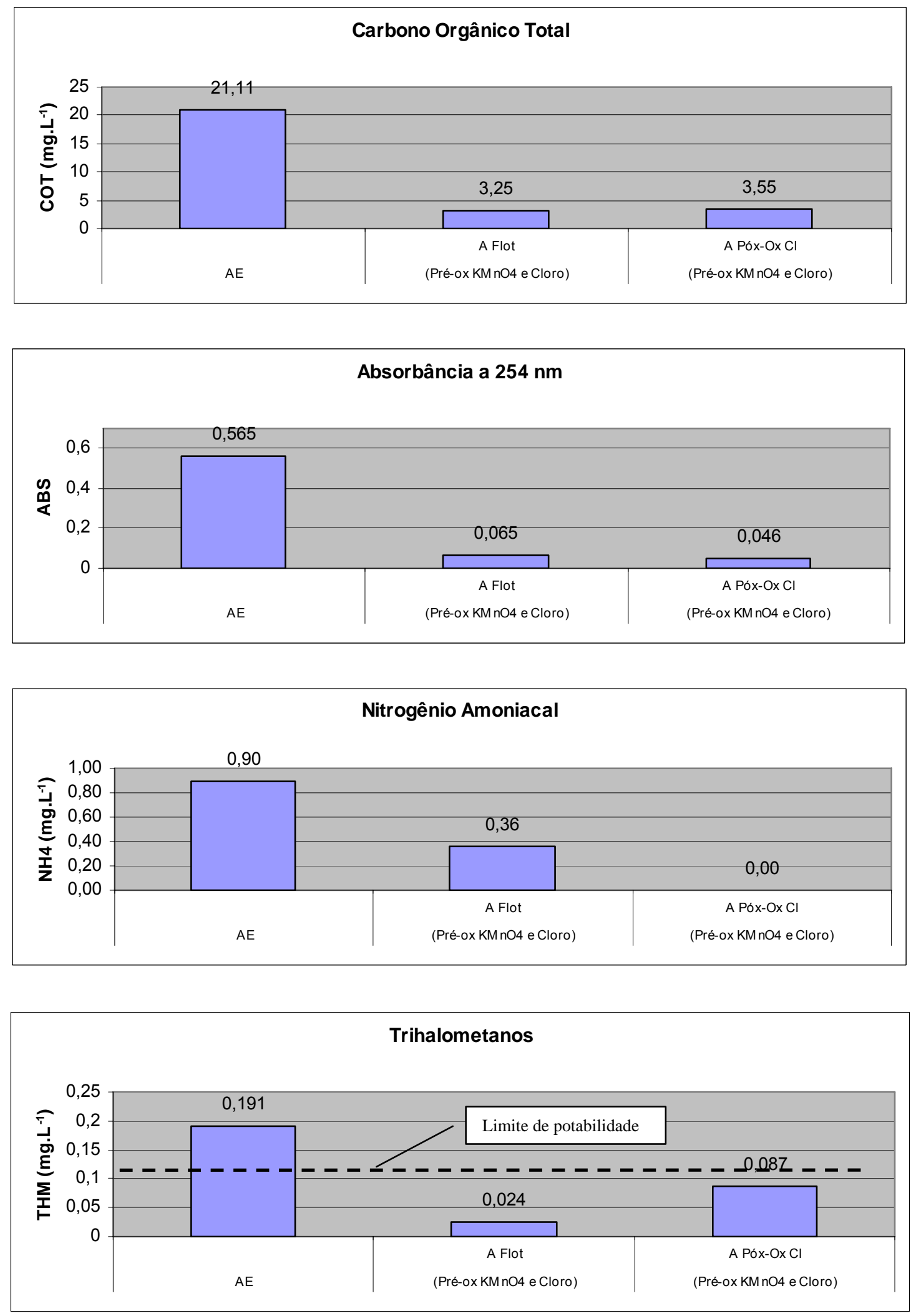

Figura 5.36 - Matéria orgânica e trihalometanos nos ensaios de pré-oxidação com a associação do permanganato de potássio e cloro (dosagem de $\mathrm{MnO}_{4}^{-}$de $3,0 \mathrm{mg} . \mathrm{L}^{-1} \mathrm{e}$ dosagem de $\mathrm{Cl}_{2}$ de 2,0 mg. $\mathrm{L}^{-1}$ ) e pós-oxidação com cloro (dosagem de $\mathrm{Cl}_{2}$ de 3,0 mg. $\mathrm{L}^{-1}$ ) 
Entretanto, comparando-se o fluxograma de tratamento que envolve a pré-oxidação somente com $\mathrm{KMnO}_{4}$ e o fluxograma que envolve a pré-oxidação com a associação de $\mathrm{KMnO}_{4}$ e cloro, observa-se que a concentração final de THM é maior no fluxograma que envolve a associação dos dois oxidantes na pré-oxidação. Já que a dosagem de cloro ativo na pós-oxidação foi igual em ambos os fluxogramas de tratamento $\left(3,0 \mathrm{mg} \cdot \mathrm{L}^{-1}\right)$, a maior formação de THM pode ser atribuída à aplicação do cloro na pré-oxidação, resultando em um balanço entre remoção e formação de THM desfavorável no fluxograma que considera a associação do $\mathrm{KMnO}_{4}$ e o cloro na etapa de pré-oxidação.

\subsection{3 - Fitoplancton}

Nos ensaios complementares, de maneira geral foi observada remoção do fitoplancton com a flotação da água de estudo, tanto tendo como base a contagem de células, conforme apresentado na figura 5.37, quanto com relação à concentração de clorofila-a, conforme apresentado na figura 5.39.

A água submetida à flotação, sem prévia oxidação, apresentou contagem de células da ordem de $10^{2}$ células. $\mathrm{mL}^{-1}$, enquanto a água de estudo apresentava contagem da ordem de $10^{6}$ células. $\mathrm{mL}^{-1}$, indicando, portanto, uma eficiência de remoção de células superior a 99,9\%. 


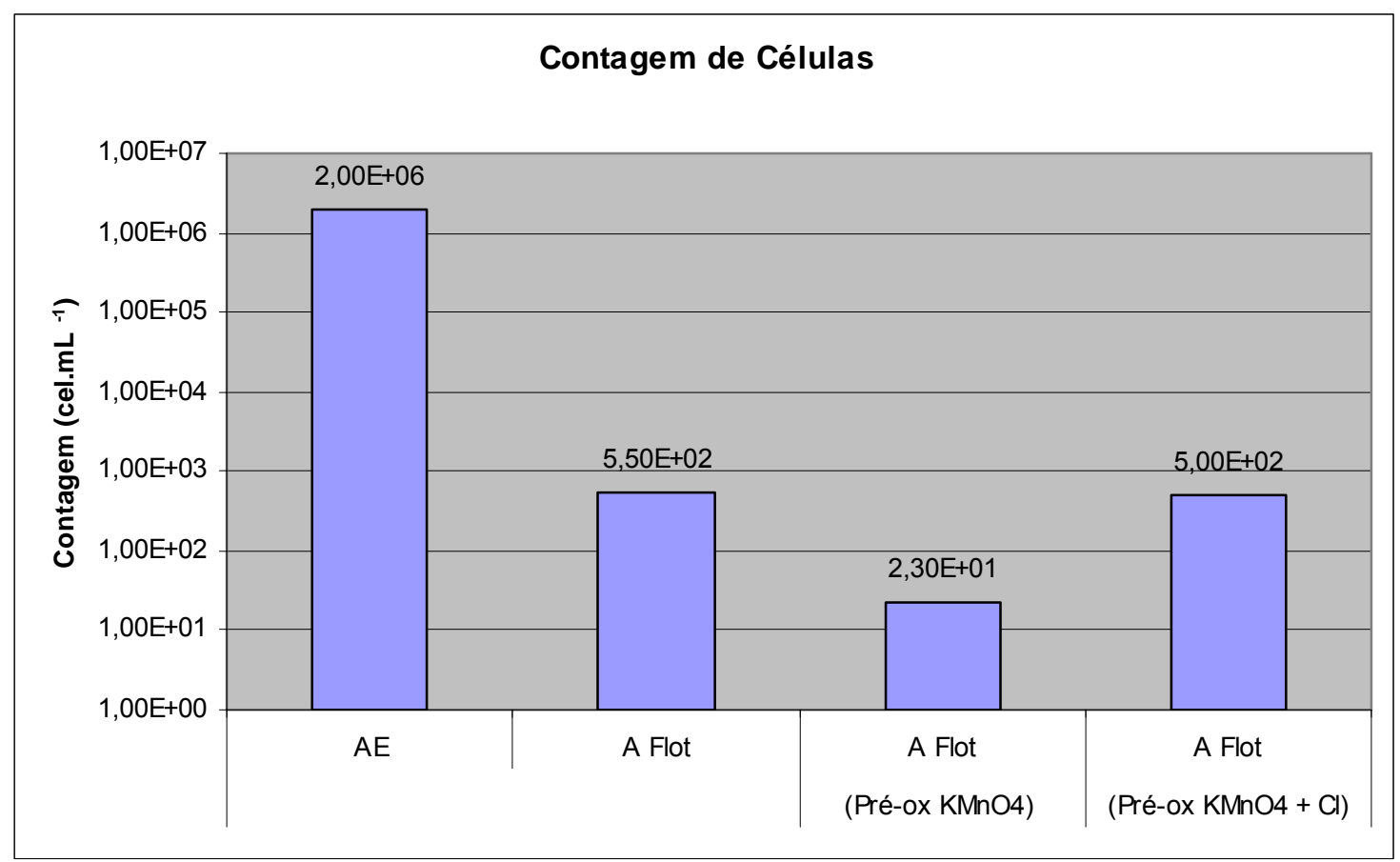

Figura 5.37 - Contagem de células nos ensaios complementares. Pré-oxidação com permanganato de potássio (dosagem de $\mathrm{MnO}_{4}^{-}$de $3,0 \mathrm{mg} . \mathrm{L}^{-1}$ ) e pré-oxidação com a associação do permanganato de potássio e cloro (dosagem de $\mathrm{MnO}_{4}^{-}$de $3,0 \mathrm{mg} . \mathrm{L}^{-1}$ e dosagem de $\mathrm{Cl}_{2}$ de 2,0 mg. $\left.\mathrm{L}^{-1}\right)$.

Conforme apresentado na figura 5.38, as águas de estudo e submetidas à flotação apresentaram diversidade semelhante com a predominância de Microcystis sp (93\% na água de estudo e $87 \%$ na água flotada), enquanto que a água pré-oxidada com permanganato de potássio e posteriormente submetida à flotação, apresentou $100 \%$ de Microcystis sp e uma menor contagem de células (da ordem de $10^{1}$ celulas. $\left.\mathrm{mL}^{-1}\right)$. 


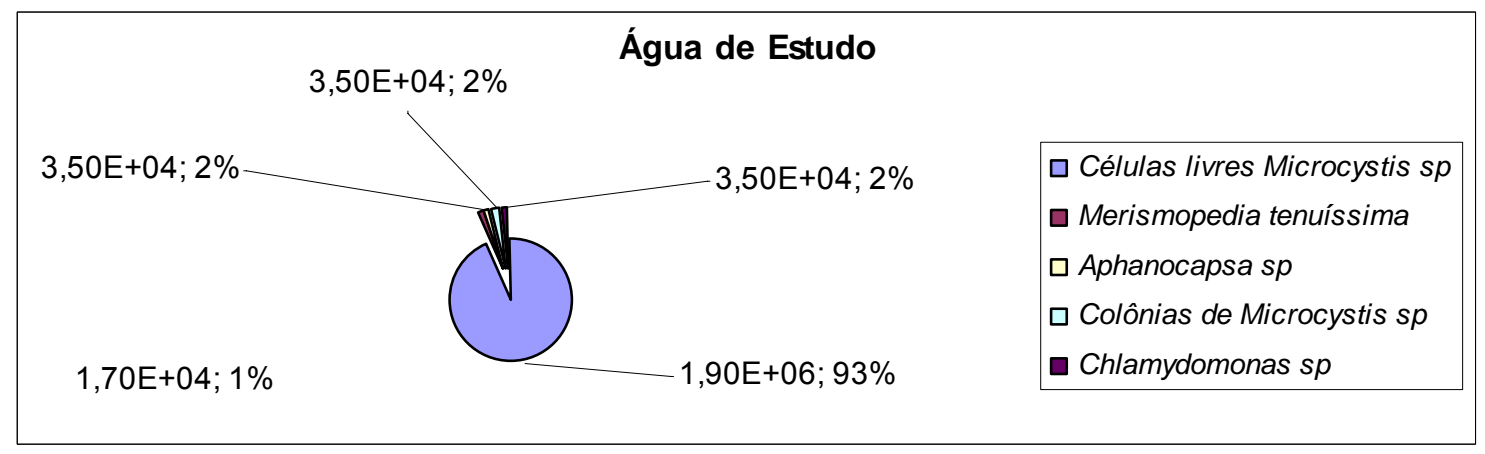
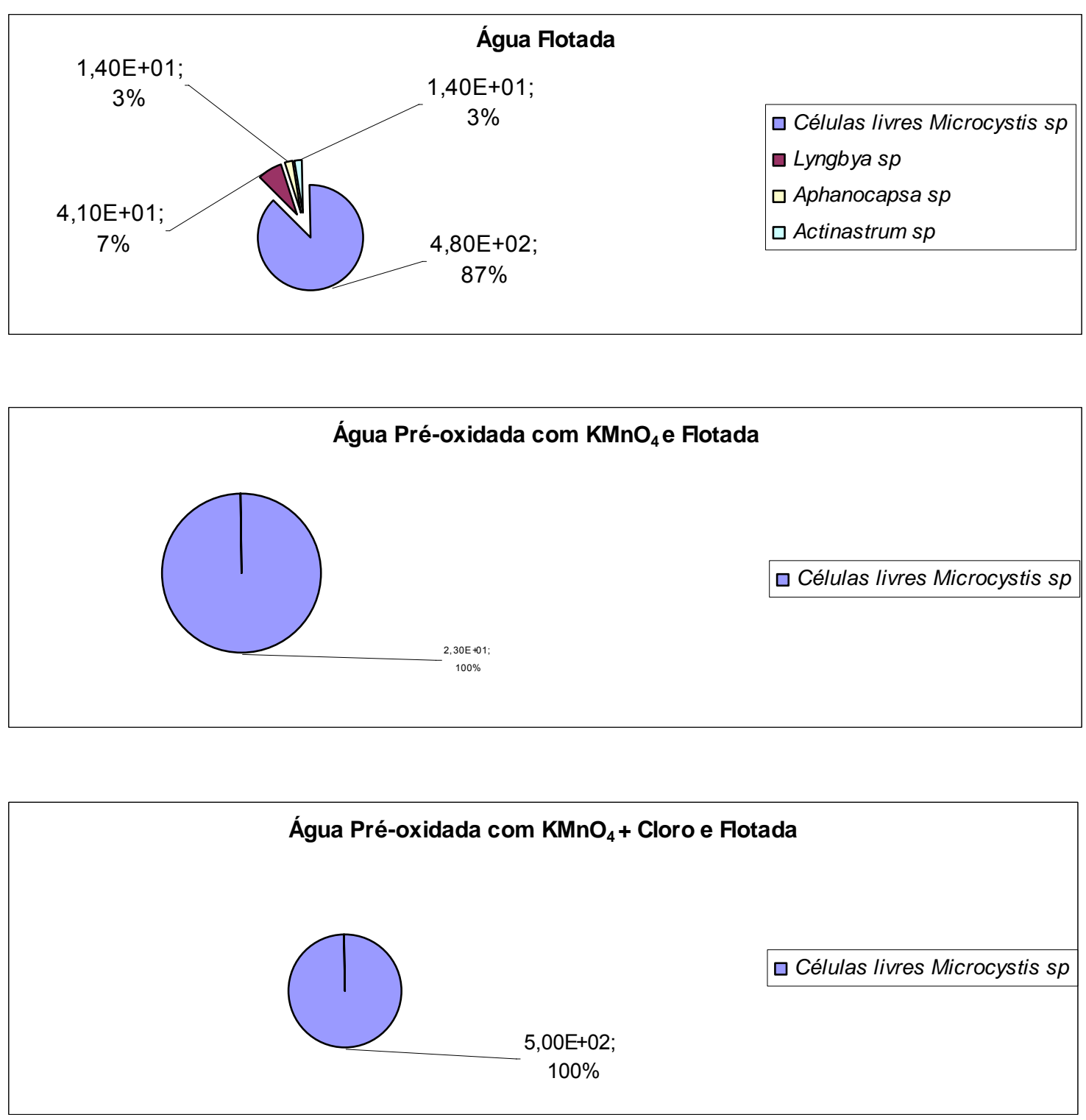

Figura 5.38 - Contagem e Identificação do Fitoplancton nos Ensaios Complementares 
Em termos de clorofila-a, a concentração remanescente na água submetida à flotação observada nos ensaios que não consideraram a pré-oxidação foi de 0,41 $\mu \mathrm{g} \cdot \mathrm{L}^{-1}$, enquanto que a água de estudo apresentava concentração de $8,2 \mu \mathrm{g} \cdot \mathrm{L}^{-1}$, resultando em uma eficiência de remoção de clorofila-a de $95 \%$.

Os resultados obtidos nos ensaios complementares confirmam os resultados obtidos por REALI et al (1993), quando a clarificação de água bruta contendo alta concentração de fitoplancton, empregando-se uma unidade de flotação em escala de laboratório, apresentou eficiência de remoção de algas superior a 97\% considerando-se velocidades ascensionais de flotação de até $30 \mathrm{~cm} \cdot \mathrm{min}^{-1}(430$ $\left.\mathrm{m}^{3} \cdot \mathrm{m}^{-2} \cdot \mathrm{dia}^{-1}\right)$ em condições adequadas de coagulação e floculação prévias. Nos ensaios em questão a velocidade ascencional de flotação foi da ordem de 170 $\mathrm{m}^{3} \cdot \mathrm{m}^{-2} \cdot \mathrm{dia}^{-1}$.

Nos ensaios relativos à oxidação, quer seja da água de estudo (pré-oxidação), da água submetida à flotação (inter-oxidação) ou da água filtrada (pós-oxidação), as concentrações de clorofila-a foram, em geral, superiores às verificadas para a água submetida à flotação sem prévia ou posterior oxidação. Entretanto, as diferenças parecem ser irrelevantes, o que não permite atribuir qualquer tipo de influência da oxidação no balanço das concentrações de clorofila-a nos ensaios em questão. 

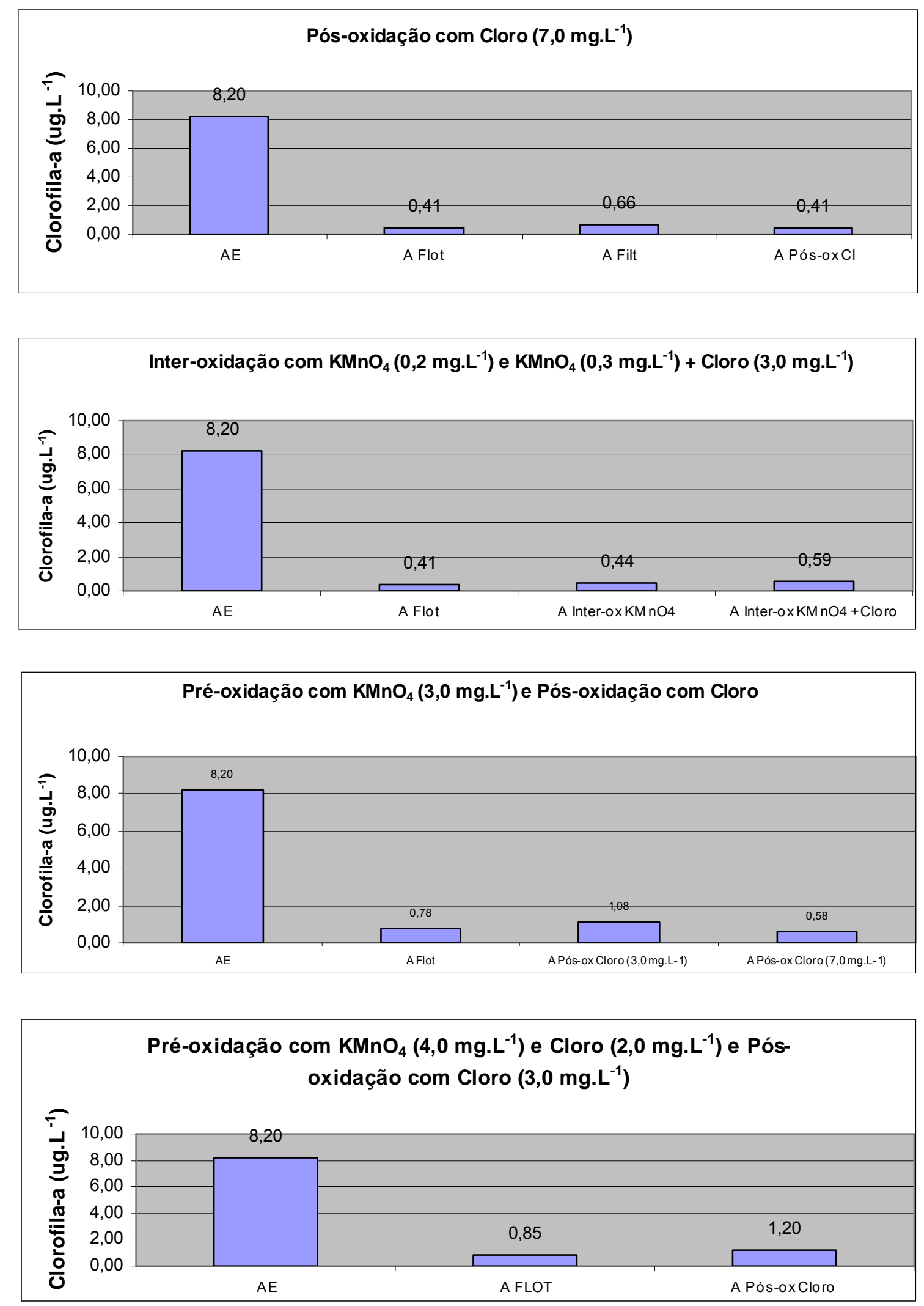

Figura 5.39 - Concentração de clorofila-a nos ensaios complementares. 


\section{7 - Análise Global dos Resultados}

O presente trabalho constitui parte relevante da linha de pesquisa desenvolvida junto ao Departamento de Hidráulica e Saneamento da Escola de Engenharia de São Carlos da Universidade de São Paulo, intitulada "Remoção de Microcistina Presente em Águas de Mananciais Eutrofizados Destinadas ao Abastecimento, com Associação das Técnicas de Flotação por Ar Dissolvido, Oxidação Química e Adsorção em Carvão Ativado“, coordenada pelo orientador desta tese.

Neste item é apresentada uma análise conjunta e comparativa dos resultados ora apresentados e obtidos nos trabalhos realizados pelos demais membros do grupo de pesquisa, relatados anteriormente no item 3.6. Pretende-se, portanto, apresentar ao leitor um panorama global dos resultados obtidos na referida linha de pesquisa até o momento.

As águas empregadas por todos os membros do grupo de pesquisa foram coletadas no reservatório de Barra Bonita - SP. Com exceção do estudo desenvolvido por FERREIRA (2005) relatado no item 3.6.2, nos outros estudos foi adotado o método de preparo da água de estudo descrito no item 4.2, ou seja, mistura da água de Barra Bonita com a cultura predominante de Microcystis $s p$ preparada em laboratório, de maneira a produzir água de estudo com concentração de microcistina extracelular na faixa de 14,0 a $18,0 \mu g \cdot \mathrm{L}^{-1}$.

Considerando as diferenças de método de preparo das águas de estudo, a presente análise global de resultados exclui o trabalho desenvolvido por FERREIRA (2005) devido as diferenças qualitativas significativas das águas de estudo e, portanto, não ser possível estabelecer uma mesma base comparativa. 
A tratabilidade das águas de estudo utilizadas nos ensaios realizados por SILVA (2005), BUENO (2005), MIGLIATI (2006) e por este doutorando, indicou a necessidade de dosagens de cloreto férrico em faixa que variou de 45 a $140 \mathrm{mg} \cdot \mathrm{L}^{-1}$, com remoção de cor e turbidez sempre superior a $90 \%$, tendo como base águas de estudo com cor aparente variando de 660 a $990 \mathrm{uH}$ e turbidez variando de 19 a 100 uT. A referida eficiência em termos de remoção de cor e turbidez, da ordem de $90 \%$, somente foi observada em uma bateria de ensaios; nas demais realizadas as eficiências atingiram valores sempre superiores a 95\%.

A adição de permanganato de potássio na água de estudo, ou seja, antes da etapa de coagulação, acarretou a necessidade de aumentar, significativamente, as dosagens de cloreto férrico para a adequação da coagulação, floculação e flotação, passando da faixa de 65 a $76 \mathrm{mg} \cdot \mathrm{L}^{-1}$, nos ensaios em que não se aplicou permanganato de potássio, para a faixa de 95 a $140 \mathrm{mg} \cdot \mathrm{L}^{-1}$ quando do emprego de tal oxidante. Caracterizando, portanto, a necessidade de uma condição de coagulação intensificada (dosagem mais elevada de coagulante) para viabilizar o emprego do permanganato de potássio na pré-oxidação química.

Embora o tratamento baseado somente na coagulação, floculação, flotação e filtração da água de estudo tenha sido eficiente na remoção do fitoplancton, não foi suficiente para o atendimento do padrão de potabilidade em termos de remoção de microcistina extracelular (dissolvida no meio líquido), cuja concentração na água de estudo variou de 10,0 a $16,0 \mu \mathrm{g} \cdot \mathrm{L}^{-1}$ durante os ensaios. A maior eficiência de remoção verificada foi da ordem de $80 \%$, resultando em concentração remanescente de microcistina livre de $2,6 \mu \mathrm{g} \cdot \mathrm{L}^{-1}$ na água filtrada, tendo como base uma água de estudo com $15,0 \mu \mathrm{g} \cdot \mathrm{L}^{-1}$ de microcistina livre no meio líquido. A referida 
eficiência em torno de $80 \%$ somente foi observada em uma bateria de ensaios, nas demais realizadas, a eficiência ficou restrita ao patamar de 15 a 20 \%.

No estudo desenvolvido por SILVA (2005), a aplicação do carvão ativado em pó foi efetiva na remoção da microcistina, sendo que, quanto maior foi o tempo de contato, maior foi a eficiência de remoção. Para águas com concentração de microcistina da ordem de $10,0 \mu \mathrm{g} \cdot \mathrm{L}^{-1}$, a aplicação de $50 \mathrm{mg} \cdot \mathrm{L}^{-1}$ de carvão ativado em pó na água de estudo a 90 minutos antes da coagulação, resultou em eficiência de remoção de microcistina livre no meio líquido superior a $90 \%$ e concentração final na água filtrada de 0,9 $\mu \mathrm{g} \cdot \mathrm{L}^{-1}$. Para essa condição de ensaio a dosagem de coagulante (cloreto férrico) foi de $45 \mathrm{mg} \cdot \mathrm{L}^{-1}$.

Para o tempo de contato de 20 segundos antes da coagulação, o padrão de potabilidade (concentração máxima de microcistina igual a $1,0 \mu \mathrm{g} . \mathrm{L}^{-1}$ ) foi praticamente atendido com uma concentração de microcistina livre no meio líquido da ordem de 1,2 $\mu \mathrm{g} \cdot \mathrm{L}^{-1}$, entretanto, para esse desempenho a dosagem de CAP foi de $60 \mathrm{mg} \cdot \mathrm{L}^{-1}$. A dosagem de cloreto férrico foi de $45 \mathrm{mg} \cdot \mathrm{L}^{-1}$ como na condição anterior de ensaio.

A adsorção com carvão ativado em pó mostrou-se menos efetiva para a remoção de microcistina quando a aplicação do CAP foi feita depois da coagulação. Para o ponto de aplicação do CAP cinco segundos após a coagulação, o padrão de potabilidade não foi atendido para nenhuma dosagem de CAP estudada.

Segundo BUENO (2005), a pré-oxidação com cloro foi eficiente na remoção de microcistina livre no meio líquido, sem produzir concentração residual de trialometanos superior ao padrão de potabilidade. Quando o cloro foi aplicado 10 segundos antes da coagulação, a concentração remanescente de microcistina ficou 
abaixo de $0,8 \mu \mathrm{g} \cdot \mathrm{L}^{-1}$ para dosagem de oxidante de $6,0 \mathrm{mg} \cdot \mathrm{L}^{-1}$ e dosagem de cloreto férrico de $50 \mathrm{mg} \cdot \mathrm{L}^{-1}$. Para as mesmas condições de dosagem, e aplicação do oxidante 90 minutos antes da coagulação, a concentração remanescente de microcistina foi da ordem de $2,4 \mu \mathrm{g} \cdot \mathrm{L}^{-1}$, não atendendo o padrão de potabilidade. Indicando que, ao contrário do verificado por SILVA (2005) na adsorção com CAP, o maior tempo de contato do oxidante com a água de estudo não foi benéfico para a remoção de microcistina, provavelmente devido ao fato de que a ação mais prolongada do oxidante pode ter causado a lise celular ou maior estresse das cianobactérias, liberando microcistina para o meio líquido, embora o cloro possa ter atuado também como oxidante da microcistina

Nos ensaios realizados por BUENO (2005), na condição de associação da préoxidação com cloro e adsorção com CAP, observa-se que para a aplicação do oxidante 10 segundos antes da coagulação e dosagem de oxidante de $6,0 \mathrm{mg} \cdot \mathrm{L}^{-1}$, a concentração de microcistina remanescente foi de $0,3 \mu g \cdot \mathrm{L}^{-1}$ utilizando uma dosagem de CAP de $20 \mathrm{mg} \cdot \mathrm{L}^{-1}$ após a coagulação. Para a condição de aplicação do oxidante 90 minutos antes da coagulação e para a mesma dosagem de CAP, a concentração remanescente de microcistina foi da ordem de $2,0 \mu \mathrm{gg} \cdot \mathrm{L}^{-1}$, não atendendo o padrão de potabilidade, tal como verificado para a mesma condição de pré-oxidação sem a aplicação de CAP.

O CAP empregado nos ensaios de adsorção de microcistina realizados por SILVA (2005) e BUENO (2005) é de origem vegetal, com número de iodo da ordem de 950 mg.g ${ }^{-1}$ e granulometria igual a $88 \%<\# 325$ mesh. O carvão utilizado foi escolhido após a realização de um estudo de avaliação de desempenho entre várias alternativas disponíveis no mercado nacional, sendo que a adoção de um carvão de origem vegetal confirma os resultados obtidos por FERREIRA FILHO (2001), que 
constatou o melhor desempenho do carvão vegetal quando comparado com o carvão de origem mineral para a remoção de substâncias orgânicas

Comparando-se a pré-oxidação estudada de forma isolada e associada à adsorção com CAP, observa-se significativa elevação da eficiência em termos de remoção de microcistina livre no meio líquido quando ocorre a associação dos dois mecanismos. Para a condição de aplicação do oxidante dez segundos antes da coagulação, a associação com a adsorção com CAP estudada por BUENO (2005), resultou em aumento de cerca de $60 \%$ na eficiência de remoção de microcistina em relação à condição de aplicação isolada da CAP estudada por SILVA (2005).

No caso da pós-oxidação com cloro estudada por MIGLIATI (2006), ou seja, o cloro aplicado após a floculação e filtração da água de estudo, foi observada efetiva remoção de microcistina a partir de dosagem de cloro livre igual ou superior a 3,0 $\mathrm{mg} \cdot \mathrm{L}^{-1}$, quando foi obtida eficiência superior a $94 \%$ mesmo para o menor tempo de contato investigado (15 minutos). Nessas condições o padrão de potabilidade foi atendido com concentração remanescente de microcistina inferior a $1,0 \mu \mathrm{g} \cdot \mathrm{L}^{-1}$ para água de estudo com concentração inicial de $15 \mu \mathrm{g} \cdot \mathrm{L}^{-1}$.

Na complementação dos ensaios de pós-oxidação com cloro realizada neste estudo, foi observado também que $\mathrm{opH}$ exerceu grande influência no desempenho da oxidação da microcistina, o aumento do pH foi acompanhado pela redução da eficiência de remoção de microcistina; concentrações remanescentes de microcistina inferiores a 1,0 $\mu \mathrm{g} \cdot \mathrm{L}^{-1}$ somente foram observadas para valores de $\mathrm{pH}$ abaixo de 7,5.

A aplicação isolada de permanganato de potássio na água submetida à flotação, de forma a caracterizar condição de "inter-oxidação", não foi efetiva para a remoção da microcistina. Foram observadas eficiências de remoção restritas à faixa de 55 a 70 
\%, com concentrações remanescentes de microcistina variando de 4,8 a $6,7 \mu \mathrm{g} \cdot \mathrm{L}^{-1}$ para uma água de estudo com concentração inicial de $15,7 \mu \mathrm{g} \cdot \mathrm{L}^{-1}$.

O baixo desempenho da aplicação isolada do permanganato de potássio na água submetida à flotação pode ser justificado pela pequena dosagem aplicada desse oxidante $\left(0,2 \mathrm{mg} \cdot \mathrm{L}^{-1}\right.$ de permanganato), pois dosagens maiores foram inviáveis de aplicação devido ao comprometimento da qualidade final da água filtrada, principalmente com relação à cor. Portanto, foi confirmada a forte tendência de aumento da cor com a aplicação do permanganato de potássio (EPA 1999).

Quando o permanganato de potássio foi aplicado associado ao cloro na água submetida à flotação (dosagem de permanganato de $0,3 \mathrm{mg} \cdot \mathrm{L}^{-1}$ e cloro ativo de 3,0 $\mathrm{mg} \cdot \mathrm{L}^{-1}$ ), ao contrário da condição de aplicação isolada, a eficiência de oxidação da microcistina foi bem mais elevada, atendendo o padrão de potabilidade em relação à microcistina com eficiência de remoção superior a $97 \%$ para valores de pH na água submetida à flotação de até 7,6 , resultando em concentrações remanescentes de microcistina inferiores $0,5 \mu \mathrm{g} \cdot \mathrm{L}^{-1}$ para a mesma água de estudo com concentração inicial de $15,7 \mu \mathrm{g} \cdot \mathrm{L}^{-1}$. Novamente foi observada a influência da variação do $\mathrm{pH}$ no desempenho da oxidação da microcistina, pois para valores de $\mathrm{pH}$ superiores a 8,9 a eficiência de oxidação foi reduzida sensivelmente, resultando em concentrações remanescentes de microcistina superiores a $2,8 \mu \mathrm{g} \cdot \mathrm{L}^{-1}$ e eficiências de remoção inferiores a $82 \%$.

O melhor desempenho da inter-oxidação quando existe a ação combinada do permanganato de potássio e do cloro, pode ser atribuída a dois fatores: 
- À própria presença do cloro, com dosagem de $3,0 \mathrm{mg} \cdot \mathrm{L}^{-1}$, que já tinha se mostrado bastante efetiva na condição de oxidação da água filtrada (pósoxidação).

- Ao fato de que foi possível aplicar dosagem maior de permanganato na água submetida à flotação sem o comprometimento da qualidade final da água filtrada, $0,2 \mathrm{mg} \cdot \mathrm{L}^{-1}$ na condição de aplicação isolada comparado com $0,3 \mathrm{mg} \cdot \mathrm{L}^{-1}$ na condição de aplicação associada com o cloro.

No caso da pré-oxidação com permanganato de potássio, ou seja, a aplicação desse oxidante na água de estudo antes da coagulação, a eficiência de remoção de microcistina livre foi da ordem de $93 \%$, com concentração remanescente de microcistina na água submetida à flotação de $1,2 \mu \mathrm{g} \cdot \mathrm{L}^{-1}$ tendo como base água de estudo com concentração inicial de $17,0 \mu \mathrm{g} \cdot \mathrm{L}^{-1}$. A pré-oxidação foi feita com dosagem de permanganato de $3,0 \mathrm{mg} \cdot \mathrm{L}^{-1}$, sendo que essa dosagem não resultou em comprometimento da água filtrada final quanto aos padrões de potabilidade, principalmente em termos de cor.

A pós-oxidação com cloro da água pré-oxidada com permanganato e flotada, resultou em pequena elevação da eficiência de remoção da microcistina livre de $93 \%$ para mais de $96 \%$, no caso da dosagem de $3,0 \mathrm{mg} \cdot \mathrm{L}^{-1}$ de cloro ativo, considerando tempo de contato de oxidação de 30 minutos. Novamente, a influência do pH na pós-oxidação da microcistina foi constatada para ambas as dosagens de cloro na pós-oxidação.

Adicionalmente, observa-se que a aplicação de permanganato de potássio na água de estudo (pré-oxidação), foi viável com uma dosagem de $\mathrm{MnO}_{4}{ }^{-}$cerca de 15 vezes superior $\left(3,0 \mathrm{mg} \cdot \mathrm{L}^{-1}\right.$ comparado com $\left.0,2 \mathrm{mg} \cdot \mathrm{L}^{-1}\right)$ à dosagem viável observada no caso da aplicação de permanganato na água submetida à flotação. Isso pode ser justificado pelas melhores condições de retenção dos óxidos mangânicos nas etapas 
de coagulação, floculação, flotação e filtração, quando o permanganato é aplicado na água de estudo. No caso da aplicação desse oxidante na água submetida à flotação, a única barreira de retenção desses óxidos é a filtração, além do menor tempo de contato de reação para a formação e floculação dos óxidos mangânicos.

Nos ensaios da pré-oxidação com a associação do permanganato de potássio e cloro, ou seja, a aplicação desses dois oxidantes na água de estudo antes da coagulação, a eficiência de remoção de microcistina livre foi da ordem de $79 \%$, com concentração remanescente de microcistina na água submetida à flotação de 3,0 $\mu \mathrm{g} \cdot \mathrm{L}^{-1}$ tendo como base uma água de estudo com concentração inicial de $14,0 \mu \mathrm{g} \cdot \mathrm{L}^{-1}$ . A pré-oxidação foi feita com dosagem de permanganato de $4,0 \mathrm{mg} \cdot \mathrm{L}^{-1}$ e de cloro ativo de 2,0 mg. $\mathrm{L}^{-1}$ sendo que a dosagem de permanganato de $4,0 \mathrm{mg} \cdot \mathrm{L}^{-1}$ não resultou em comprometimento da água filtrada final quanto aos padrões de potabilidade, principalmente em termos de cor. Novamente foi observado que a associação do permanganato com o cloro viabilizou maior dosagem de permanganato sem o comprometimento da qualidade da água filtrada final quando comparada com a dosagem relativa à pré-oxidação exclusivamente com o permanganato, ou seja: $3,0 \mathrm{mg} \cdot \mathrm{L}^{-1}$ comparado a $4,0 \mathrm{mg} \cdot \mathrm{L}^{-1}$.

Comparando-se o desempenho da pré-oxidação com permanganato de potássio associado ou não ao cloro, observa-se que houve redução de eficiência de remoção da microcistina livre, pois a eficiência verificada passou de $93 \%$, no caso da préoxidação exclusiva com o permanganato para $79 \%$, no caso da pré-oxidação com a associação de permanganato e cloro. Essa queda de desempenho apresenta indícios de que a mais enérgica pré-oxidação realizada com a associação dos dois oxidantes muito provavelmente deve ter contribuído com maior lise celular e, conseqüentemente, maior liberação de microcistina para o meio líquido, 
comprometendo a eficiência de remoção de microcistina até a etapa de flotação. Observa-se também que a aplicação do cloro na etapa de pré-oxidação contribuiu para maior formação de THM, conforme é discutido com mais detalhes adiante.

Na seqüência do mesmo ensaio, ou seja, após as etapas de pré-oxidação com permanganato de potássio e cloro, coagulação, floculação e flotação, a pósoxidação com cloro proporcionou remoção adicional de microcistina extracelular, com elevação da eficiência global de remoção deste contaminante de $79 \%$ para mais de $98 \%$, para dosagem de $3,0 \mathrm{mg} \cdot \mathrm{L}^{-1}$ de cloro ativo, tempo de contato de oxidação de 30 minutos e pH de até 7,25.

Nos ensaios em que não foi considerada a pré-oxidação da água de estudo, observa-se que as eficiências de remoção de microcistina obtidas até a etapa de flotação são muito distintas, tendo como base a microcistina total (soma das parcelas intra e extracelular) ou a microcistina extracelular. Considerando-se o fluxograma de tratamento até a etapa de flotação da água de estudo, foram observadas eficiências de remoção de microcistina total muito superiores: valores da ordem de 95 a 98\%, em relação à eficiência de remoção de microcistina extracelular, com valores da ordem de $17 \%$ e $83 \%$, indicando que quando considerada a presença global da toxina, ou seja, com a inclusão da parcela intracelular, a flotação é bastante efetiva na remoção de microcistina, obviamente devido à reconhecida eficiênciada dessa técnica na remoção de fitoplancton. Nessas condições de ensaio as amostras de água submetida à flotação apresentaram concentrações remanescentes de microcistina total (soma das parcelas intracelular e extracelular) na faixa de 2,6 a 13,0 $\mu \mathrm{g} \cdot \mathrm{L}^{-1}$ para águas de estudo com concentração de microcistina total variando na faixa de 274 a $338 \mu \mathrm{g} \cdot \mathrm{L}^{-1}$. 
Adicionalmente, observou-se que o maior potencial de toxicidade está na parcela intracelular. Após a implementação da determinação de microcistina total, foi observado nas águas de estudo ensaiadas que a concentração de microcistina total era cerca de 18 a 33 vezes superior à concentração de microcistina extracelular, o que evidenciou a predominância de microcistina contida no interior das células. Portanto, a remoção das células íntegras e a adoção de procedimentos que evitem a lise celular é fundamental em sistemas de tratamento que sejam abastecidos por mananciais que apresentem potencial de ocorrência de cianobactérias. A flotação por ar dissolvido certamente contribui de forma significativa nesse aspecto, devido à sua grande eficiência na remoção do fitoplancton e, conseqüentemente, na remoção da microcistina intracelular, conforme constatado nos ensaios realizados.

Nos ensaios em que foram consideradas a pré-oxidação com permanganato de potássio de forma isolada ou associada ao cloro, a superioridade da eficiência de remoção de microcistina total em relação a microcistina extracelular também foi constatada nas amostras de água submetida à flotação. Entretanto, de forma menos significativa, pois foram observadas eficiências de remoção de microcistina total superiores a $99 \%$, enquanto que em termos de microcistina livre foram observados valores na faixa de 78 a $92 \%$, que embora sejam inferiores aos valores relativos à microcistina total, são superiores em relação à eficiência de remoção de microcistina livre relativos às condições de ensaio sem pré-oxidação (faixa de 17 a 83\%).

Entretanto, é importante observar que simultaneamente à pré-oxidação visando a remoção de microcistina extracelular, ocorreu a lise celular e conseqüente liberação de microcistina intracelular para o meio líquido, fazendo com que a influência da remoção de material celular íntegro, exclusivamente devido à flotação, fosse em parte ocultada pelas influências positiva e negativa simultâneas da pré-oxidação. 
Em todos os fluxogramas de tratamento estudados, foram observados indícios da remoção dos trialometanos devido ao efeito benéfico de "stripping" inerente ao processo de flotação por ar dissolvido. Por outro lado, a aplicação do cloro como agente oxidante sempre resultou em indícios de formação de THM, quer seja na etapa de pré-oxidação quer seja na pós-oxidação, confirmando os resultados obtidos por DINIZ (2005) e OLIVEIRA (2002).

Ocorreu, portanto, o balanço entre remoção e formação dos trihalometanos nas diversas etapas de cada fluxograma de tratamento. Considerando que a remoção de THM por stripping deve ter sido similar em todos os ensaios devido à mesma condição de coagulação e floculação quanto aos gradientes de velocidade e tempos de mistura, bem como à mesma condição de flotação quanto ao volume de água saturada e quantidade de ar, presume-se que as diferentes concentrações de THM obtidas em cada ensaio podem ser atribuídas, preponderantemente, às diferentes condições de oxidação de cada amostra quanto à quantidade de matéria orgânica e dosagens de oxidante.

Embora o cloro contribua com formação dos THM, destaca-se o efeito benéfico da aplicação do permanganato de potássio, pois essa substância cumpre o papel de agente oxidante sobre matéria orgânica e outras substâncias sem, contudo, contribuir com a formação dos THM, conforme observado pela EPA (1999), DINIZ (2005) e OLIVEIRA (2002).

Presume-se que a aplicação do cloro na pré-oxidação deve ter sido relevante na formação dos trihalometanos devido à maior quantidade de matéria orgânica na água de estudo, entretanto, a presença de matéria orgânica, ainda que em menor quantidade nas amostras de água submetida à flotação ou filtrada, também foi 
relevante para a formação dos trihalometanos quando associada à presença do cloro. Toma-se como exemplo o ensaio de pós-oxidação segundo a dosagem de 7,0 mg. $\mathrm{L}^{-1}$ de cloro livre, pois nessa condição de ensaio foi observada a maior concentração de $\operatorname{THM}\left(0,146 \mathrm{mg} \cdot \mathrm{L}^{-1}\right)$ na água tratada.

A seguir, apresenta-se um resumo geral dos resultados obtidos pelo grupo de pesquisa, em termos de desempenho de remoção de microcistina extracelular. 
Tabela 5.34 - Remoção de Microcistina Extracelular e Trialometanos. Resumo Geral das Condições Experimentais Estudadas pelo Grupo de Pesquisa formado por SILVA (2005), BUENO (2005), MIGLIATI (2006) e por este autor.

\begin{tabular}{|c|c|c|c|c|c|c|c|c|c|c|c|c|}
\hline \multirow{3}{*}{$\begin{array}{l}\text { Condição } \\
\text { de } \\
\text { Ensaio }\end{array}$} & \multicolumn{6}{|c|}{$\begin{array}{l}\text { Dosagens } \\
\left.(\mathrm{mg.L})^{-1}\right)\end{array}$} & \multirow{3}{*}{$\begin{array}{l}\text { Tempo de } \\
\text { Contato } \\
\text { Oxidação } \\
\text { (min) }\end{array}$} & \multicolumn{3}{|c|}{ Microcistina Extracelular ( $\mu$ g. ${ }^{-1}$ ) } & \multicolumn{2}{|c|}{ THM (mg.L -1 $\left.^{-1}\right)$} \\
\hline & \multirow[t]{2}{*}{ CAP } & \multicolumn{5}{|c|}{ Oxidantes } & & \multirow{2}{*}{$\begin{array}{c}\text { Água } \\
\text { de Estudo }\end{array}$} & \multirow{2}{*}{$\begin{array}{l}\text { Remanescente } \\
\text { ao final do } \\
\text { fluxograma } \\
\end{array}$} & \multirow{2}{*}{$\begin{array}{c}\text { Eficiência } \\
\text { Remoção } \\
(\%) \\
\end{array}$} & \multirow{2}{*}{$\begin{array}{c}\text { Água } \\
\text { de Estudo }\end{array}$} & \multirow{2}{*}{$\begin{array}{c}\text { Remanescente } \\
\text { ao final do } \\
\text { fluxograma } \\
\end{array}$} \\
\hline & & $\begin{array}{c}\text { Cloro } \\
\text { pré }\end{array}$ & $\begin{array}{c}\mathrm{KMnO}_{4} \\
\text { pré }\end{array}$ & $\begin{array}{c}\mathrm{KMnO}_{4} \\
\text { inter }\end{array}$ & $\begin{array}{l}\text { Cloro } \\
\text { inter }\end{array}$ & $\begin{array}{l}\text { Cloro } \\
\text { pós }\end{array}$ & & & & & & \\
\hline Flotação Exclusiva & - & - & - & - & - & - & - & 15,7 & 13,0 & 17,2 & - & - \\
\hline $\begin{array}{l}\text { Pré-CAP } \\
\text { (90 min antes coagulação) }\end{array}$ & 50,0 & - & - & - & - & - & - & 10,0 & 0,9 & 91,0 & - & - \\
\hline $\begin{array}{l}\text { Pré-oxidação cloro } \\
\text { (10 s antes coagulação) }\end{array}$ & - & 6,0 & - & - & - & - & - & 14,5 & 0,8 & 94,5 & - & - \\
\hline $\begin{array}{l}\text { Pré-oxid. cloro + CAP } \\
\text { Cloro } 10 \text { s antes coagulação } \\
\text { CAP após coagulação }\end{array}$ & 20,0 & 6,0 & - & - & - & - & - & 14,5 & 0,3 & 97,9 & - & - \\
\hline $\begin{array}{l}\text { Pós-oxidação cloro } \\
\text { Aplicação na Água filtrada }\end{array}$ & - & - & - & - & - & 3,0 & 30 & 15,0 & 0,8 & 94,7 & 0,191 & $0,146(*)$ \\
\hline Inter-oxidação $\mathrm{KMnO}_{4}$ & & & & & & & & & & & & \\
\hline $\mathrm{KMnO}_{4}$ na água flotada & - & - & - & 0,2 & - & - & 15 & 15,7 & 4,8 & 69,4 & & \\
\hline $\begin{array}{l}\text { Inter-oxidação } \mathrm{KMnO}_{4}+ \\
\text { Cloro na água flotada }\end{array}$ & - & - & - & 0,3 & 3,0 & - & 15 & 15,7 & 0,4 & 97,5 & 0,191 & 0,125 \\
\hline
\end{tabular}

Condições Experimentais que não Atenderam o Padrão de Potabilidade com Relação à Microcistina (concentração remanescente $>1,0 \mu \mathrm{g} . \mathrm{L}^{-1}$ )

(*) Considera dosagem de cloro na pós-oxidação de $7,0 \mathrm{mg} \cdot \mathrm{L}^{-1}$. 
Tabela 5.34 - Remoção de Microcistina Extracelular e Trihalometanos. Resumo Geral das Condições Experimentais Estudadas pelo grupo de Pesquisa formado por SILVA (2005), BUENO (2005), MIGLIATI (2006) e por este autor. (Continuação)

\begin{tabular}{|c|c|c|c|c|c|c|c|c|c|c|c|c|}
\hline \multirow{3}{*}{$\begin{array}{c}\text { Condição } \\
\text { de } \\
\text { Ensaio }\end{array}$} & \multicolumn{6}{|c|}{$\begin{array}{l}\text { Dosagens } \\
\left(\mathrm{mg}^{-L^{-1}}\right)\end{array}$} & \multirow{3}{*}{$\begin{array}{l}\text { Tempo de } \\
\text { Contato } \\
\text { Oxidação } \\
\text { (min) }\end{array}$} & \multicolumn{3}{|c|}{ Microcistina Extracelular $\left(\mu \mathrm{g} . \mathrm{L}^{-1}\right)$} & \multicolumn{2}{|c|}{ THM (mg.L $\left.{ }^{-1}\right)$} \\
\hline & \multirow[t]{2}{*}{ CAP } & \multicolumn{5}{|c|}{ Oxidantes } & & \multirow{2}{*}{$\begin{array}{c}\text { Água } \\
\text { de Estudo }\end{array}$} & \multirow{2}{*}{$\begin{array}{l}\text { Remanescente } \\
\text { ao final do } \\
\text { fluxograma } \\
\end{array}$} & \multirow{2}{*}{$\begin{array}{c}\text { Eficiência } \\
\text { Remoção } \\
\text { (\%) } \\
\end{array}$} & \multirow{2}{*}{$\begin{array}{c}\text { Água } \\
\text { de Estudo }\end{array}$} & \multirow{2}{*}{$\begin{array}{c}\text { Remanescente } \\
\text { ao final do } \\
\text { fluxograma } \\
\end{array}$} \\
\hline & & $\begin{array}{c}\text { Cloro } \\
\text { pré }\end{array}$ & $\begin{array}{c}\mathrm{KMnO}_{4} \\
\text { pré }\end{array}$ & $\begin{array}{c}\mathrm{KMnO}_{4} \\
\text { inter }\end{array}$ & $\begin{array}{l}\text { Cloro } \\
\text { inter } \\
\end{array}$ & $\begin{array}{c}\text { Cloro } \\
\text { pós } \\
\end{array}$ & & & & & & \\
\hline $\begin{array}{l}\text { Pré-oxidação } \\
\mathrm{KMnO}_{4} 60 \text { s antes da } \\
\text { coagulação }\end{array}$ & - & - & 3,0 & - & - & - & - & 17,0 & 1,2 & 92,9 & - & - \\
\hline $\begin{array}{l}\text { Pré-oxidação } \mathrm{KmnO}_{4} \\
\text { Pós-oxidação Cloro } \\
\mathrm{KMnO}_{4} 60 \text { s antes da } \\
\text { coagulação } \\
\text { Cloro na água flotada }\end{array}$ & - & - & 3,0 & - & - & 3,0 & 30 & 17,0 & 0,2 & 98,8 & 0,191 & 0,073 \\
\hline $\begin{array}{l}\text { Pré-oxidação } \mathrm{KMnO}_{4}+\text { cloro } \\
\mathrm{KMnO}_{4} 120 \text { s antes da } \\
\text { coagulação } \\
\text { Cloro } 60 \text { s antes coagulação }\end{array}$ & - & 2,0 & 4,0 & - & - & - & - & 14,0 & 3,0 & 78,8 & - & - \\
\hline $\begin{array}{l}\text { Pré-oxidação } \mathrm{KMnO}_{4}+\text { cloro } \\
\text { Pós-oxidação Cloro }\end{array}$ & & & & & & & & & & & & \\
\hline $\begin{array}{l}\mathrm{KMnO}_{4} 120 \text { s antes coag. } \\
\text { Cloro } 60 \mathrm{~s} \text { antes coagulação }\end{array}$ & - & 2,0 & 4,0 & - & - & 3,0 & 30 & 14,0 & 0,2 & 98,4 & 0,191 & 0,087 \\
\hline Cloro na água flotada & & & & & & & & & & & & \\
\hline
\end{tabular}

Condições Experimentais que não Atenderam o Padrão de Potabilidade com Relação à Microcistina (concentração remanescente $>1,0 \mu \mathrm{g} \cdot \mathrm{L}^{-1}$ ) 


\section{8 - Estudo Econômico Simplificado}

Neste item é apresentado estudo econômico simplificado, que considera somente os custos operacionais decorrentes do consumo de produtos químicos, bem como o transporte e disposição final do lodo produzido. Não foram considerados os custos relativos ao consumo de energia elétrica e remuneração de equipe de operação e manutenção, por serem admitidos similares para todas as condições de estudo.

Dentre todas as condições experimentais avaliadas pelo grupo de pesquisa, para este estudo econômico foram escolhidas as condições que atenderam ao padrão de potabilidade relativo à microcistina, conforme indicado na tabela 5.34 , listadas na sequência:

- Aplicação isolada de CAP na água de estudo (90 minutos antes da coagulação);

- Pré-oxidação com cloro;

- Pré-oxidação com cloro associada à aplicação de CAP após a coagulação;

- Pós-oxidação com aplicação de cloro na água filtrada;

- Inter-oxidação com aplicação associada de permanganato de potássio e cloro na água submetida à flotação;

- Pré-oxidação com permanganato de potássio e pós-oxidação com cloro;

- Pré-oxidação com a aplicação associada de permanganato de potássio e cloro e pós-oxidação com cloro.

Os custos operacionais foram baseados no levantamento dos consumos de CAP e dos oxidantes, segundo as dosagens definidas nos ensaios. Com relação ao coagulante, foi adotada dosagem de $65 \mathrm{mg} \cdot \mathrm{L}^{-1}$ de cloreto férrico, para as condições de ensaio que não consideraram a aplicação de permanganato de potássio na água de estudo, e $140 \mathrm{mg} \cdot \mathrm{L}^{-1}$ para as demais condições avaliadas. Também foi 
considerado consumo de polímero para o desaguamento do lodo produzido, com dosagem média de aplicação de $8,0 \mathrm{~g} \cdot \mathrm{kg}^{-1}$ de massa seca de sólidos produzida, conforme recomendação dos fabricantes dos equipamentos de desaguamento.

Para a avaliação da produção de lodo e conseqüente estimativa de seu custo de transporte e disposição final, foi adotada a seguinte expressão, extraída do PROSAB (1999):

Ts $=($ Dosagem de cloreto férrico $\times 0,40)+($ Turbidez da água bruta $\times 1,5)$

Onde:

- Ts é a taxa de produção de lodo, expressa em gramas de sólidos secos por metro cúbico de água tratada;

- Dosagem de cloreto férrico em $\mathrm{mg} \cdot \mathrm{L}^{-1}$,

- Turbidez da água bruta em uT;

- 0,40 é o fator de produção de lodo em função do tipo de coagulante empregado, no caso em questão, o cloreto férrico hidratado (cristal $\mathrm{FeCl}_{3} \cdot 6 \mathrm{H}_{2} \mathrm{O}$ );

- 1,5 é a razão entre a concentração de sólidos suspensos totais na água bruta e a turbidez da mesma (faixa de 1,0 a 2,0)

No caso das condições experimentais com aplicação de CAP, foi adicionada à expressão apresentada anteriormente a contribuição de sólidos devido à dosagem de CAP na razão igual a 1,0, ou seja, massa de CAP aplicada, diretamente convertida em massa de lodo produzida.

Os custos de fornecimento dos produtos químicos foram adotados com base nos preços médios obtidos mediante consultas feitas a fornecedores, bem como prestadores de serviço no caso do transporte e disposição final do lodo produzido, com data base de janeiro de 2008 , quais sejam: 
- Cloreto férrico: 0,87 R\$. $\mathrm{kg}^{-1}$ (fornecimento de solução comercial a $40 \%$, em massa, com massa específica igual a $\left.1,4 \mathrm{~kg} \cdot \mathrm{L}^{-1}\right)$;

- Permanganato de potássio: $15,00 \mathrm{R} \$ . \mathrm{kg}^{-1}$ (fornecimento em sacas);

- Hipoclorito de sódio: $0,77 \mathrm{R} \$ \cdot \mathrm{kg}^{-1}$ (fornecimento de solução comercial a $10 \%$, em massa, com massa específica igual a $\left.1,2 \mathrm{~kg} \cdot \mathrm{L}^{-1}\right)$;

- Carvão ativado em pó (CAP): 3,00 R $\$ \cdot \mathrm{kg}^{-1}$ (fornecimento em sacas);

- Polímero auxiliar de desaguamento: $15,00 \mathrm{R} \$ . \mathrm{kg}^{-1}$ (fornecimento em barricas);

- Transporte e disposição final do lodo produzido: 60,00 $\mathrm{R} \$ . \operatorname{ton}^{-1}$ de lodo desaguado (base úmida)

Com base nos critérios adotados no presente estudo econômico simplificado, foram determinados, para cada condição de ensaio, custos operacionais unitários expressos em $\mathrm{R} \$$ por metro cúbico de água produzida. Para a determinação do volume de água efetivamente produzido, foi considerado o desconto das perdas operacionais decorrentes do descarte de lodo e lavagem dos filtros, avaliadas em $4,0 \%$ do volume de água bruta captada.

A tabela 5.35 apresenta os custos operacionais unitários de cada condição de ensaio avaliada, bem como as respectivas eficiências em termos de remoção de microcistina com base na tabela 5.34 .

Para efeito de avaliação econômica comparativa, na tabela 5.34 também são apresentados os acréscimos de custo em comparação ao custo unitário da condição de pós-oxidação com cloro, considerada como base de avaliação tendo em vista representar condição típica de tratamento de água para abastecimento público, pois a aplicação de cloro na água filtrada é adotada com a finalidade de desinfecção. 
Tabela 5.35 - Resumo dos Custos Unitários e Eficiências de Remoção de Microcistina

\begin{tabular}{|c|c|c|c|c|c|c|c|c|c|c|c|c|c|c|}
\hline \multirow[t]{2}{*}{$\begin{array}{l}\text { CONDIÇÃO } \\
\text { EXPERIMENTAL }\end{array}$} & \multicolumn{2}{|c|}{$\mathrm{Fe}_{2} \mathrm{Cl}_{3}$} & \multicolumn{2}{|c|}{ CAP } & \multicolumn{2}{|c|}{$\mathrm{KMnO}_{4}$} & \multicolumn{2}{|c|}{$\mathrm{NaOCl}$} & \multicolumn{2}{|c|}{ Lodo } & \multicolumn{2}{|c|}{$\begin{array}{l}\text { CUSTO UNITÁRIO } \\
\left(\mathbf{R} \$ / \mathbf{m}^{3}\right)\end{array}$} & \multicolumn{2}{|c|}{$\begin{array}{l}\text { MICROCISTINA } \\
\text { RESIDUAL }\end{array}$} \\
\hline & $\begin{array}{l}\text { Custo } \\
\left(\mathbf{R} \$ . \mathbf{m}^{-3}\right)\end{array}$ & $\begin{array}{c}\% \\
(*)\end{array}$ & $\begin{array}{l}\text { Custo } \\
\left(\mathrm{R} \$ . \mathrm{m}^{-3}\right)\end{array}$ & $\begin{array}{c}\% \\
(*)\end{array}$ & $\begin{array}{l}\text { Custo } \\
\left(\mathbf{R} \$ . \mathbf{m}^{-3}\right)\end{array}$ & $\begin{array}{c}\% \\
(*)\end{array}$ & $\begin{array}{l}\text { Custo } \\
\left(\mathbf{R} \$ . \mathbf{m}^{-3}\right)\end{array}$ & $\begin{array}{c}\% \\
(*)\end{array}$ & $\begin{array}{l}\text { Custo } \\
\left(\mathbf{R} \$ . \mathrm{m}^{-3}\right)\end{array}$ & $\begin{array}{c}\% \\
(*)\end{array}$ & Total & $\begin{array}{l}\text { Acréscimo em } \\
\text { Relação à } \\
\text { Condição Base } \\
\end{array}$ & $\begin{array}{l}\text { Concentração } \\
\left(\mu g . L^{-1}\right)\end{array}$ & $\begin{array}{c}\text { Efic. } \\
\text { Remoção } \\
(\%) \\
\end{array}$ \\
\hline $\begin{array}{l}\left.\text { CAP ( } 50 \text { mg. } L^{-1}\right) \text { na água de } \\
\text { estudo }\end{array}$ & 0,15 & 39,9 & 0,16 & 42,3 & - & - & - & - & 0,07 & 17,8 & 0,37 & 0,16 & 0,9 & 91,0 \\
\hline $\begin{array}{l}\text { Pré-oxidação c/ Cloro } \\
\left(6 \mathrm{mg} . \mathrm{L}^{-1}\right)\end{array}$ & 0,15 & 62,4 & - & - & - & - & 0,05 & 20,4 & 0,04 & 17,3 & 0,24 & 0,03 & 0,8 & 94,5 \\
\hline $\begin{array}{l}\text { Pré-oxidação c/ Cloro } \\
\left(6 \text { mg. } L^{-1}\right)+\text { CAP }\left(20 \text { mg.L }{ }^{-1}\right)\end{array}$ & 0,15 & 47,7 & 0,06 & 20,3 & - & - & 0,05 & 15,6 & 0,05 & 16,4 & 0,31 & 0,10 & 0,3 & 97,9 \\
\hline $\begin{array}{l}\text { Pós-oxidação c/ Cloro } \\
\left(3 \mathrm{mg} \cdot \mathrm{L}^{-1}\right)(* *)\end{array}$ & 0,15 & 69,4 & - & - & - & - & 0,02 & 11,3 & 0,04 & 19,2 & 0,21 & 0,00 & 0,8 & 94,7 \\
\hline $\begin{array}{l}\text { Inter-oxidação c/ } \mathrm{KMnO}_{4} \\
\left(0,3 \mathrm{mg} \cdot \mathrm{L}^{-1}\right)+\mathrm{Cl}\left(3 \mathrm{mg} \cdot \mathrm{L}^{-1}\right)\end{array}$ & 0,15 & 67,4 & - & - & 0,01 & 2,9 & 0,02 & 11,0 & 0,04 & 18,7 & 0,22 & 0,01 & 0,4 & 97,5 \\
\hline $\begin{array}{l}\text { Pré-oxidação c/ } \mathrm{KMnO}_{4} \\
\left(3 \mathrm{mg} \cdot \mathrm{L}^{-1}\right) \text { e pós-oxidação c/ } \\
\text { cloro }\left(3 \mathrm{mg} . \mathrm{L}^{-1}\right)\end{array}$ & 0,32 & 68,8 & - & - & 0,06 & 13,8 & 0,02 & 5,2 & 0,06 & 12,1 & 0,46 & 0,25 & 0,2 & 98,8 \\
\hline $\begin{array}{l}\text { Pré-oxidação c/ } \mathrm{KMnO}_{4} \\
\left(4 \mathrm{mg} . \mathrm{L}^{-1}\right)+\mathrm{Cl}_{2}\left(2 \mathrm{mg} . \mathrm{L}^{-1}\right) \text { e } \\
\text { pós-oxid. c/ cloro }\left(3 \mathrm{mg} . \mathrm{L}^{-1}\right)\end{array}$ & 0,32 & 63,7 & - & - & 0,09 & 17,1 & 0,04 & 8,1 & 0,06 & 11,2 & 0,50 & 0,29 & 0,2 & 98,4 \\
\hline
\end{tabular}

(*) Porcentagem em relação ao custo unitário total

$(* *)$ - Condição base para efeito comparativo 
Com os dados apresentados na tabela 5.35, observa-se que com exceção a condição de aplicação de CAP na água de estudo, a parcela de custo operacional mais relevante em todas as condições experimentais estudadas foi a relativa ao consumo de coagulante, pois esta representou de 47 a $70 \%$ dos custos operacionais totais determinados neste estudo econômico simplificado. No caso das condições experimentais que consideraram a aplicação de permanganato de potássio na água de estudo, ou seja, antes das etapas de coagulação, floculação e flotação, o custo operacional relativo à aplicação do cloreto férrico foi significativamente maior que o custo relativo às outras condições experimentais $\left(0,32 \mathrm{R} \$ \cdot \mathrm{m}^{-3}\right.$ comparado a $\left.0,15 \mathrm{R} \$ \cdot \mathrm{m}^{-3}\right)$, sendo que essa grande diferença foi decorrente da maior dosagem de coagulante para estabelecer condição de coagulação intensificada, necessária para compensar o efeito negativo do permanganato de potássio na elevação da cor da água a ser tratada.

Entre as condições de ensaio que atenderam ao padrão de potabilidade em termos de remoção de microcistina, observa-se que a pós-oxidação com cloro segundo dosagem de 3,0 mg. $\mathrm{L}^{-1}$, foi a condição mais vantajosa em termos econômicos, pois apresentou o menor custo unitário total e representa condição típica de tratamento de água, sendo, portanto, considerada como base de avaliação comparativa nesse estudo econômico simplificado, conforme citado anteriormente.

Destaca-se também, em termos econômicos, a condição de inter-oxidação com a aplicação associada do permanganato de potássio e cloro na água submetida à flotação, pois representa um acréscimo de custo, em relação ao custo da alternativa de pós-oxidação com cloro, da ordem de 0,01 R $\$ . \mathrm{m}^{-3}$, ou seja, um acréscimo de apenas $4,7 \%$ em relação ao referido custo base. O pequeno acréscimo é atribuído à 
pequena dosagem de permanganato de potássio que foi viável de aplicação na água submetida à flotação. Conforme pode ser observado na tabela 5.34, a condição de inter-oxidação com aplicação associada de permanganato de potássio e cloro resultou em aumento significativo de eficiência de remoção de microcistina e redução de formação de trialometanos, quando comparado com a condição de pósoxidação com cloro.

No outro extremo em termos econômicos, encontram-se a condição de pré-oxidação com permanganato de potássio associada a pós-oxidação com cloro, bem como a condição de pré-oxidação com a associação de permanganato de potássio e cloro e pós-oxidação com cloro. Embora essas duas condições experimentais tenham resultado nos melhores desempenhos em termos de remoção de microcistina, conforme observado na tabela 5.34, apresentaram os maiores custos unitários totais e, conseqüentemente, os maiores acréscimos de custo em relação à condição base de pós-oxidação com cloro, cerca de 0,25 a $0,29 \mathrm{R} \$ \cdot \mathrm{m}^{-3}$, que representam, respectivamente, aumento de 119 a 138 \% em relação ao custo base. Em termos de formação de trialometanos essas duas condições experimentais foram as mais adequadas tecnicamente, resultando em concentrações remanescentes de THM abaixo de 0,09 mg. $\mathrm{L}^{-1}$, atendendo com segurança o padrão de potabilidade.

Em um patamar intermediário em termos de custo unitário total e, conseqüentemente, em termos de acréscimo de custo em relação à condição base de pós-oxidação com cloro, encontram-se as demais condições aexperimentais apresentadas na tabela 5.35. As condições de aplicação de CAP na água de estudo e de pré-oxidação com cloro associada a aplicação de CAP na água coagulada, apresentaram acréscimo de custo em relação à condição base de pós-oxidação com cloro de 0,10 a $0,16 \mathrm{R} \$ \cdot \mathrm{m}^{-3}$, sendo que esse acréscimo siginificativo é atribuído às 
elevadas dosagens de CAP (20 e $\left.50 \mathrm{mg} \cdot \mathrm{L}^{-1}\right)$, cujo efeito também incide nos custos de condicionamento e disposição final do lodo. A condição de pré-oxidação com cloro apresentou acréscimo de custo em relação à condição base de pós-oxidação com cloro de 0,03 R $\$ \cdot \mathrm{m}^{-3}$. 


\section{6 - CONCLUSÕES}

Com base nos resultados obtidos, em termos gerais, conclui-se que:

- Em todos os ensaios de oxidação química realizados, foi confirmada a influência da variação do $\mathrm{pH}$ no desempenho da remoção de microcistina, sendo que quanto menores foram os valores de $\mathrm{pH}$ melhor foi o desempenho do processo oxidativo.

- Em todas as amostras de águas de estudo preparadas e empregadas nos ensaios, a maior concentração de microcistina foi observada na parcela intracelular, ou seja, a microcistina contida no interior das células íntegras. Essa constatação indica a importância do emprego de procedimentos que evitem ou reduzam a liberação de toxina, por lise ou estresse celular, em sistemas de abastecimento cujos mananciais apresentam potencial de ocorrência de intensas florações de cianobactérias.

- A etapa de flotação por ar dissolvido foi eficaz apenas para a remoção da microcistina intracelular, pois foi obtida remoção de fitoplancton acima de $99 \%$ e consequentemente, eficiência de remoção de microcistina total (soma das parcelas intracelular e extracelular) na faixa de 96 a 99,7 \%. Em termos de microcistina extracelular, ou seja, a parcela dissolvida no meio líquido, a eficiência de remoção atingiu valor de $83 \%$, em um único ensaio, e ficou restrita à faixa de 15 a $20 \%$ nos demais ensaios realizados.

- Com relação aos trialometanos, os resultados obtidos indicam que a formação dessas substâncias foi mais pronunciada quando o cloro foi aplicado na água de estudo, por esta conter maior concentração de matéria orgânica precursora da formação de THM quando oxidada com cloro. Entretanto, a prévia oxidação da matéria orgânica contida na água de estudo com a aplicação de permanganato de potássio, contribuiu para reduzir a formação de THM na etapa de pósoxidação com cloro da água submetida à flotação. Em todas as condições experimentais, foram observados indícios de remoção dos THM por volatilização, provavelmente devido ao mecanismo de stripping que ocorre na etapa de flotação por ar dissolvido. 
Para cada condição experimental estudada no presente trabalho, considerando as águas de estudo utilizadas nos ensaios com concentração de microcistina extracelular variando na faixa de 14 a $17 \mu \mathrm{g} \cdot \mathrm{L}^{-1}$, conclui-se que:

- A pós-oxidação com cloro, segundo dosagem de 3,0 mg. $\mathrm{L}^{-1}$, apresentou remoção de microcistina extracelular superior a 94\%, com concentração residual de 0,8 $\mu \mathrm{g} . \mathrm{L}^{-1}$. Essa condição experimental apresentou o menor custo operacional, cerca de $R \$ 0,21$ por metro cúbico de água produzida, segundo resultados obtidos em avaliação econômica simplificada. Ressalta-se que a condição de pós-oxidação com cloro foi considerada como base de comparação no estudo econômico simplificado, pois representa situação típica de sistemas de tratamento de água, devido à prática de desinfecção final da água filtrada com aplicação de cloro.

- A aplicação de 0,2 mg. $\mathrm{L}^{-1}$ de permanganato de potássio após a coagulação, floculação e flotação da água de estudo, de forma a caracterizar condição de inter-oxidação, resultou em concentração residual de microcistina de 4,8 $\mu \mathrm{g} \cdot \mathrm{L}^{-1}$, não sendo capaz de atender ao limite máximo de $1,0 \mu \mathrm{g} \cdot \mathrm{L}^{-1}$ estabelecido no padrão de potabilidade. Entretanto, a associação do permanganato de potássio e do cloro na mesma condição de inter-oxidação, resultou em remoção de microcistina extracelular satisfatória com eficiência superior a $97 \%$ e concentração residual de $0,4 \mu \mathrm{g} \cdot \mathrm{L}^{-1}$. Essa condição de inter-oxidação com a associação dos dois oxidantes aplicados na água submetida à flotação, apresentou um dos menores custos operacionais dentre as condições experimentais estudadas, cerca de $\mathrm{R} \$ 0,22$ por metro cúbico de água produzida, o que representa um acréscimo de apenas $4,7 \%$ em relação ao custo operacional da condição de pós-oxidação com cloro.

- A etapa de pré-oxidação com aplicação de $3,0 \mathrm{mg} \cdot \mathrm{L}^{-1}$ de permanganato de potássio resultou em concentração residual de microcistina de $1,2 \mu \mathrm{g} \cdot \mathrm{L}^{-1}$, não sendo capaz de atender ao limite máximo de $1,0 \mu \mathrm{g} \cdot \mathrm{L}^{-1}$ estabelecido no padrão de potabilidade. Entretanto, a pós-oxidação com cloro segundo dosagem de 3,0 $\mathrm{mg} \cdot \mathrm{L}^{-1}$, da água pré-oxidada com permanganato de potássio, resultou na complementação da remoção de microcistina extracelular, com concentração residual de $0,2 \mu \mathrm{g} \cdot \mathrm{L}^{-1}$. Essa condição experimental apresentou a maior eficiência em termos de remoção de microcistina $(98,8 \%)$ dentre as condições 
experimentais estudada. Em contrapartida, apresentou custo operacional de cerca de $\mathrm{R} \$ 0,46$ por metro cúbico de água produzida, que representa um acréscimo de $119 \%$ em relação ao custo operacional da condição de pósoxidação com cloro.

- A pré-oxidação com a associação do permanganato de potássio $\left(4,0 \mu \mathrm{g} \cdot \mathrm{L}^{-1}\right) \mathrm{e}$ cloro $\left(2,0 \mu \mathrm{g} \cdot \mathrm{L}^{-1}\right)$, ambos aplicados antes da etapa de coagulação, não foi suficiente para o atendimento do padrão de potabilidade em termos de microcistina, com concentração residual desse contaminante de $3,0 \mu \mathrm{g} \cdot \mathrm{L}^{-1}$. Entretanto, a pós-oxidação com cloro segundo dosagem de $3,0 \mathrm{mg} \cdot \mathrm{L}^{-1}$, da água pré-oxidada com a associação do permanganato de potássio e cloro, resultou na complementação da remoção de microcistina extracelular, com eficiência de 98,4 $\%$ e concentração residual desse contaminante de $0,2 \mu \mathrm{g} \cdot \mathrm{L}^{-1}$. A pré-oxidação mais enérgica da água de estudo com a associação do permanganato de potássio e cloro, quando comparada com a aplicação isolada do permanganato de potássio, resultou em maior valor de concentração residual de microcistina devido à ocorrência de maior liberação de toxina intracelular. Essa condição de ensaio apresentou custo operacional de cerca de $R \$ 0,50$ por metro cúbico de água produzida, que representa um acréscimo de $138 \%$ em relação ao custo operacional da condição de pós-oxidação com cloro. 


\section{7 - RECOMENDAÇÕES}

A realização do presente trabalho experimental permitiu, além das conclusões apresentadas anteriormente, observações importantes, as quais conduziram à elaboração das seguintes recomendações de ordem prática e para trabalhos de pesquisa futuros:

- Nos sistemas de tratamento de água para abastecimento, é reforçada a recomendação da prática usual de aplicação de substância alcalinizante para a estabilização química da água tratada no final da câmara de contato. Dessa forma, são proporcionadas melhores condições de remoção da microcistina extracelular remanescente, devido a promover a oxidação segundo o máximo tempo de contato e em meio aquoso com baixo valor de $\mathrm{pH}$, antes que ocorra a aplicação do alcalinizante.

- Nos projetos de sistemas produtores de água para abastecimento, cujos mananciais apresentem grande potencial de ocorrência de florações de cianobactérias tóxicas, a técnica de flotação por ar dissolvido constitui alternativa atraente e, portanto, deve sempre ser considerada nos estudos de concepção, devido à sua grande eficiência de remoção do fitoplancton e, portanto, da relevante parcela de toxina contida no interior das células.

- Nos projetos de novas estações de tratamento de água, bem como na reforma ou ampliação de estações existentes, a aplicação de permanganato de potássio pode constituir opção atraente a ser avaliada nos estudos de concepção, tendo em vista os bons resultados obtidos em termos de remoção de microcistina e os indícios de redução do potencial de formação de trihalometanos. As diferentes possibilidades, bem sucedidas, de aplicação do permanganato de potássio em termos de dosagem e local de aplicação, sugerem que o sistema de preparo e aplicação da solução de permanganato de potássio seja projetado com capacidade para ampla faixa de dosagem e diferentes pontos de aplicação, de maneira a proporcionar flexibilidade operacional ao sistema de tratamento.

- A realização de estudo visando o aperfeiçoamento do método de extração de microcistina intracelular utilizado neste trabalho (congelamento e 
descongelamento sucessivo da amostra) ou proposição de método alternativo, de forma a viabilizar determinação mais precisa da parcela de microcistina intracelular e, consequentemente, de microcistina total.

- A realização de novos estudos com águas que contenham concentrações de microcistina superiores à faixa adotada neste estudo (14 a $17 \mu \mathrm{g} \cdot \mathrm{L}^{-1}$ ), para a reavaliação das condições experimentais segundo condições mais críticas.

- A realização de estudos complementares de adsorção com carvão ativado em pó, após a etapa de flotação, bem como do emprego do carvão ativado granular na forma de colunas de adsorção, a jusante da filtração, de forma a se constituir em barreira final para a remoção de microcistina e de outos contaminantes ou subprodutos indesejáveis.

- A realização de novos estudos com a investigação de remoção de outras cianotoxinas, considerando as condições experimentais estudadas para a remoção de microcistina.

- A realização de estudos destinados à identificação dos subprodutos formados pela oxidação das cianotoxinas e avaliação de sua toxicidade.

- A realização de estudos específicos para a investigação mais detalhada do efeito de stripping da flotação por ar dissolvido na remoção dos trialometanos.

- A ampliação da escala dos estudos de remoção de microcistina com a realização de experimentos em unidade piloto. $\mathrm{O}$ aumento de escala irá demandar grande quantidade de água com elevada concentração de cianotoxinas, sendo que o método de preparo da água de estudo, que foi desenvolvido para a escala de laboratório, é limitado para a produção de grande volume de água com essas características. Portanto, sugere-se a realização dos ensaios em escala piloto com a utilização de água de estudo integralmente natural, mediante a instalação de unidade piloto junto a manancial com elevado potencial de eutrofização e predominância de cianobatérias tóxicas. Nessas condições de ensaio, o cronograma de pesquisa deverá estar intimamente vinculado às variações sazonais da qualidade da água bruta captada, de maneira a possibilitar a realização dos ensaios utilizando água bruta natural com elevada concentração de cianotoxinas. 


\section{8 - REFERÊNCIAS BIBLIOGRÁFICAS}

ACERO, J. L.; RODRIGUEZ, E. \& MERILUOTO, J. (2005). Kinetics of Reactions Between

Chlorine and Cyanobacterial Toxins Microcystins. Water Research, V. 39, pp. 1628 - 1638.

ANSElme, C.; DUGUet, P.; MALLEVIALLE, J. \& SUFFET, I. H. (1992). Ozonation of Organics Compounds Causing Taste and Odor Problems. In:

APHA American Public Health Association (1999). Standard Methods for the Examination of Water and Wastewater. 19 th editions. Baltimore: port City, 1268p.

AWWA (1995) - Cyanobacterial (Blue-Green Algal) Toxins: A Resource Guide. American Water Works Association- Research Foundation, U.S.A.

AWWA (2005) - Standard Methods for the Examination of Water and Wastewater. American Water Works Association $-21^{\text {st }}$ Edition.

BAKER, P. D. \& FABBRO, L. D. (1999). A Guide to Identification of Common Blue-Green Algae in Australias Freshwaters. Cooperative Researsh Centre for Freshwater Ecology, Albury.

BANSAL et al (1998). Activated Carbon. Ed. Marcel Dekker

BERNHARDT, H., CLASEN, J. (1994) - Investigations into the Floculation Mechanisms of Small Algae Cells. J. Water SRT - AQUA. Vol. 43, London, UK.

BLACK, J. G. (2002). Microbiologia: fundamentos e perspectivas. $4^{\mathrm{a}}$ ed.. Editora Guanabara Koogan S.A. 829 p.

BRANCO, S. M. (1978). Hidrobiologia aplicada à engenharia sanitária. 2a ed. CETESB, São Paulo, Companhia de Saneamento Ambiental. 620 p.

BROOKES, J. D.; GANF, G. G.; OLIVER, R. L. (2000). Heterogeneity of cyanobacterial gasvesicle volume and metabolic activity. Journal of Plankton Research, v. 22, n. 8, p. 15791589.

BUENO, F. B. A. (2005). Tratamento de Água para Abastecimento Contendo Cianobactérias e Microcistina em Sistema Constituído por Etapas de Pré-Cloração, Coagulação/Floculação e Adsorção em Carvão Ativado. Dissertação (Mestrado), Universidade de São Paulo Escola de Engenharia de São Carlos - Departamento de Hidráulica e Saneamento. 
CALIJURI M. C. (1999) - A Comunidade Fitoplanctônica em um Reservatório Tropical (Barra Bonita, SP). Tese de Livre-Docência. Escola de Engenharia de São Carlos. Universidade de São Paulo, São Carlos. 211pp.

CALIJURI, M. C. ; ALVES, M. S. A. ; SANTOS, A. C. A. (2006). Cianobactéris e Cianotoxinas em Águas Continentais. Editora Rima, Primeira Edição, São Carlos - SP.

CASS, Q. B e DEGANI A. L. G. (2001) Desenvolvimento de Métodos por HPLC: Fundamentos, estratégias e validação - São Carlos: EdUFSCar, 77p (Série Apontamentos).

CETESB (2001) - "Relatório de Qualidade das Águas Interiores do Estado de São Paulo 2000"- Série Relatórios, Companhia de Tecnologia de Saneamento Ambiental, São Paulo $\mathrm{SP}$.

CHEN, x.; Kiao, B.; Liu, J.; Fang. T. \& xu. X. (2005). Kinetics os The Oxidation of MCRR by Potassium Permanganate. Toxicon, V. 45, pp. 911 - 917.

CHARMICHAEL, W. W. (1994). The Toxins of Cyanobacteria. Scientific American. 270(1) pp. 78-86.

CHORUS, I. e BARTRAM, J. (1999). Toxic Cyanobacteria in Water. E \& FN Spon, Londres, $416 \mathrm{p}$.

CHOW, C. W. K.; HOUSE, J.; VELZEBOER, R. M. A.; DRIKAS, M.; BURCH, M.D. \& STEFFENSEN, D. A. (1997) - The Efect of Ferric Chloride Flocculations on Cyanobacterial Cells. Water Research. V. 32. Nº 3 p. $808-814$.

CHOW, C. W. K.; HOUSE, J.; VELZEBOER, R. M. A.; DRIKAS, M.; BURCH, M.D. \& STEFFENSEN, D. A. (1998) - The Impact of Conventional Water Treatment Processes on Cells of the Cyanobacterium Microcystis aeruginosal. Water Research V. $33, N^{\circ} 15$, p. 3253 -3262 .

DANIEL, L. A. - coordenador - (2001). Processos de Desinfecção e Desinfetantes Alternativos na Produção de Água Potável. Rio de Janeiro, RiMa, ABES.

DI BERNARDO, L. (1994) - Remoção de Algas em Estações de Tratamento de Água . VI Simpósio Luso-Brasileiro de Engenharia Sanitária e Ambiental. Florianópolis, Brasil.

DI BERNARDO, L. (1995). Algas e suas Influências na Qualidade das Águas e nas Tecnologias de Tratamento. Rio de Janeiro, ABES, 127p. 
DINIZ, S. (2005). Controle da Formação de Sub-produtos da Desinfecção (THM's) em Águas de Abastecimento. Dissertação (Mestrado), Escola Politécnica da Universidade de São Paulo, Departamento de Engenharia Hidráulica e Sanitária. São Paulo. 194 p.

DOMBROSKI, S. A. G. (1996). Influência da Floculação na Eficiência de Flotação por Ar Dissolvido Aplicada ao Tratamento de Água de Abastecimento. São Carlos, Dissertação (Mestrado), Universidade de São Paulo - Escola de Engenharia de São Carlos Departamento de Hidráulica e Saneamento, 195p.

DUARTE, R. G. (1982). Eutrofização da Represa do Lobo: Observações Sobre Fatores que Contribuem para a Eutrofização de Represas em Climas Tropicais. Tese (Doutorado), Departamento de Saúde Ambiental, Faculdade de Saúde Pública, Universidade de São Paulo, 269p.

EDZWALD, J.K. (1995) - " Principles and Applications of Dissolved Air Flotation. In: IVES, K.J. , BERNHARDT, H.J., Flotation Processes in Water and Sludge Treatment. Water Science \& Technology, Great Britain, v. 31, n.3-4, p. 1-23.

EPA (1999). Guidance Manual - Alternative Disinfectants and Oxidants. Environmental Protection Agency

ESTEVES, F.A. (1988). Fundamentos de Limnologia. Editora Interciência - FINEP. Rio de Janeiro. 602p.

FALCONER, I. R. , RUNNEGAR, M. T. C. , BUCKLEY, T. , HUYN, V. L. \& BRADSHAW, P. (1989) - "Using Activated Carbon to Remove Toxicity From Drinking Water Containing Cyanobacterial Blooms". Journal of the American Water Works Association, U.S.A.

FASTNER, J. et al (2002). An international intercomparison exercise for the determination of purified microcystin-LR and microcystins in cyanobacterial field material. Anal Bioanal Chem, 374, p. 437-444.

FERREIRA FILHO, S. S. (2001). Remoção de Compostos Orgânicos Causadores de Gosto e Odor em Águas de Abastecimento: Modelação Matemática e Otimização do Processo de Adsorção em Carvão Ativado em Pó para o Sistema Produtor Guarapiranga. Tese de Livre Docência, Escola Politécnica da Universidade de São Paulo, Departamento de Engenharia Hidráulica e Sanitária. São Paulo.

FERREIRA, L. P. H. (2004). Remoção da Biomassa Algal e Determinacao da Concentração de Microcistina em Ensaios de Coagulação, Sedimentação, Filtração e Adsorcao com 
Emprego do Método ELISA. Dissertação (Mestrado), Escola de Engenharia de São Carlos da Universidade de São Paulo, Departamento de Hidráulica e Saneamento.

HARADA, K.; KONDO, F. e LAWTON, L. (1999) Laboratory analysis of cyanotoxins. em CHORUS, I. e BARTRAM, J. (editores) Toxic Cyanobacteria in Water: A Guide to their Public Health - Consequences, Monitoring and Management, pp. 369-405. Londres : E. \& F.N. Spon.

HART, J. , FAWELL, J.K. \& CROLL, B. (1997) - "Algal Toxins in Surface Water: Origins and Removal During Drinking Water Treatment Processes". IWSA World Congress, 1997.

HAUTMAN, D. P. \& MUNCH, D. J. (1997). Development of U.S. EPA Method 55.1. Journal of Chromatographic Science. V. 35, p 221-231.

HO, L.; ONSTAD, G.; GUNTEN, U. V.; PFEIFFER, S. R.; CRAIG, K. \& NEWCOMBE, G. (2006). Differences in the Chlorine Reactivity of Four Microcystin Analogues. Water Research, V. 40 , pp $1200-1209$.

HOEGER, S. J. ; SHAW, G. ; HITZFELD, B. C. \& DIETRICH, D. R. (2004) - Ocurrence and Elimination of Cyanobacterial Toxins in Two Australian Drinking Water Treatment Plants.

Toxicon V. 43 , p 639 - 649.

JONES, G. , MINATOL, W. , CRAIG, K. \& NAYLOR, R. (1993) - "Removal of Low Level Cyanobacterial Peptide Toxins from Drinking Water Using Powdered and Granular Activated Carbom and Chlorination - Results of Laboratory and Pilot Plant Studies". $15^{\text {th }}$ Federal Convention of the Australian Water \& Wastewater Association, 1993, Queensland, Austrália.

KAYA, K. et al (2001). Selective determination of total normal microcystin by colorimetry, LC/UV detection and/or LC/MS. Analytica Chimica Acta, v. 450, p. 73-80.

LAGE FILHO, F. A. \& FERREIRA FILHO, S. S. (1997). Estudo Piloto de Tratabilidade de Águas Eutrofizadas: Efeitos da Pré-Oxidação com Cloro Livre no Processo de Filtração. In: Anais do $19^{\circ}$ Congresso Brasileiro de Engenharia Sanitária e Ambiental.

LIN, T. ; HOANG, S. (2000). Inhalation Exposure to THM's from Drinking Water in South Taiwan. The Science of the Total Environmental. 246, p.41-49.

LOBATO, S.J.M. , REALI, M.A.P. , FAITANIN, L. (1995) - “O sucesso do Emprego da Flotação por Ar Dissolvido no Pré-tratamento da Água Bruta da ETE Meaípe - ES". CONGRESSO 
BRASILEIRO DE ENGENHARIA SANITÁRIA E AMBIENTAL, 18, Salvador, 1995. Anais, Disco 5/9. Salvador, ABES

MA, J. \& LIU, W. (2001). Effectiveness and Mechanism of Potassium Ferrate (VI) Preoxidation for Algae Removal by Coagulation. Water Research, n. 36, p. 871-878.

MACKINTOSCH, C. ; MACKINTOSCH, R. W. (1994). The inhibitioin of protein phosphatases by toxics: Implications for health and extremely sensitive and rapid bioassay for toxin detection em CODD, G. A. et al (editores). Detection methods for cyanobacterial toxins, p. 90-100; Cambridge, UK. Ed. The royal society of chemistry.

MALLEVIALLE, J.; SUFFET, I. H. \& CHAN, U. S. Influence and Removal fo Organics in Drinking Water. Lewis Publishers, Mexico.

MIGLIATI, E. H. (2006). Monitoramento da Evolução da Toxicidade de Uma Cultura de Microcystis aeruginosa e Avaliação da remoção de Microcistina por Oxidação com Hipoclorito de Sódio, Coagulação e Flotação por Ar Dissolvido. Trabalho de Iniciação Científica, Universidade de São Paulo - Escola de Engenharia de São Carlos Departamento de Hidráulica e Saneamento.

MONTIEL, A. \& WELTÉ, B. (1998). Preozonation Coupled with Flotation Filtration: Successful Removal of Algae. Water Science Technology, v. 37, n. 2, p. 65-73.

NICHOLSON, B. C.; BURCH, M. D. (2001). Evaluation of analytical methods for detections and quantification of cyanotoxins in relations to Australian drinking water guidelines. NHMRC/WSAA/CRC for Water Quality and Treatment

NICHOLSON, B. C.; ROSITANO, J. \& BURCH, M D. (1994). Destruction of Cyanobacterial Peptide Hepatotoxins by Chlorine and Choramine. Water Research n. 28, $\mathrm{n}^{\circ}$ 6, pp 12971303.

NUSH, E. A. (1980). Comparaison os Different Methods for Chrlorophyll-a and Pheopigment Determination. Arch. Hydrobiol. Bech. Stuttgart, v. 14, p. 14-36.

OLIVEIRA, A. C. (2002). Minimização da Formação de Trihalometanos no Tratamento de Águas de Abastecimento. Dissertação (Mestrado), Escola Politécnica da Universidade de São Paulo, Departamento de Engenharia Hidráulica e Sanitária. São Paulo. 120 p.

PÁDUA, V. L. ; FERREIRA, A. C. S. (2004). Potenciais Fatores de Risco à Saúde Decorrentes da Presença de Subprodutos de Cloração na Água Utilizada para Consumo 
Humano. Caderno de Pesquisa em Engenharia de Saúde Pública. Fundação Nacional da Saúde - Brasília, FUNASA, p. 97-134.

PIETERSE, A. J. H. , CLOTO, A. (1997) - Algal Cells and Coagulation, Floculation and Sedimentation Processes.

PROSAB (1999). Noções Gerais de Tratamento e Disposição Final de Lodos de Estações de Tratamento de Água. PROSAB - Programa de Pesquisa em Saneamento Básico. $1^{\text {a }}$ Edição. Ed RiMa - São Carlos - SP.

REALI, M.A.P. \& GIANOTTI, E.P. (1993). Remoção de Algas por Flotação: Testes de Laboratório. Congresso Brasileiro de Engenharia Sanitária e Ambiental, 17, Natal, 1993. Anais v. 2, Natal, ABES. P. 229-242.

REALI, M.A.P. e CAMPOS, J.R. (1995). "Optimization of Colour Removal using a Batch Flotation Test". World-Wide Symposium: Pollution in Large Cities - Science and Technology for Planning Environmental Quality. OMS?OPS, Venice/Pádua, Itália, 22-25 de fev. de 1995. Proceedings: 2nd SIBESA - ABES/ANDIS, 1995, p. 199-210.

REALI, M. A. P. \& SANTOS, S. P. (1999). Emprego de uma Unidade de Flotação de Alta Taxa com Escoamento Vertical para Remoção de Algas de Águas para Abastecimento. Engenharia e Arquitetura - Caderno de Engenharia Sanitária e Ambiental - vol. 1, n. 1.

SANTOS, S.P. (1997) - "Estudo de Uma Unidade de Flotação por Ar Dissolvido com Escoamento Vertical entre Placas, Aplicada à Remoção de Algas em Águas de Abastecimento". São Carlos. Dissertação (Mestrado), Escola de Engenharia de São Carlos, Universidade de São Paulo.

SCHOPF, J. W. (2000). The Fóssil record: Tracing the roots of the cyanobacterial lineage em WITTON, B. A. ; POTTS, M (editors). The Ecology Cyanobacteria Their Diversity in Time and Space. Kluwer Academic Publishers (ed).

SILVA, A. L. V. (2005). Remoção de Fitoplâncton e Microcistina de Águas para Abastecimento em Sistema que Associa Unidades de Adsorção por Carvão Ativado em Pó, Flotação por Ar Dissolvido e Filtração em Escala de Laboratório. Dissertação (Mestrado), Universidade de São Paulo - Escola de Engenharia de São Carlos - Departamento de Hidráulica e Saneamento. 
SIVONEN, K.; JONES, G. (1999). Cyanobacterial toxins em CHORUS, I. e BARTRAM, J. (editores) Toxic Cyanobacteria in water: A Guide to their Public Health - Consequences, Monitoring and Management, pp. 369-405. Londres: E. \& F. N. Spon.

SNOEYINK, U. K. et al (1994). Adsorption of organic compounds in water quality and treatment: a handbook of community water supplies. American Water Works Association. $4^{\circ}$ edição. Ed. McGraw-Hill.

SWOBODA, U. K. et al (1994). Alternatives to the mouse bioassay for cyanobacterial toxicity assessment em CODD, G. A. et al (editores). Detection methods for cyanobacterial toxins, $\mathrm{p}$. 106-110, Cambrige: Ed. The Royal Society of Chemistry.

TEIXEIRA, M. R. ; ROSA, M. J. (2006). Comparing Dissolved Air Flotation and Conventional Sedimentation to remove Cyanobacterial cells of Microcystis aeruginosa. Part II - The Effect of Water Background Organics. Separation and Purification Technology. www.sciencedirect.com.

TEIXEIRA, M. R. ; ROSA, M. J. (2006). Comparing Dissolved Air Flotation and Conventional Sedimentation to remove Cyanobacterial cells of Microcystis aeruginosa. Part I - The Key Operating Conditions. Separation and Purification Technology. www.sciencedirect.com.

TEIXEIRA, M. R. ; ROSA, M. J. (2006). Integration of Dissolved Gás Flotation and Nanofiltration for M. aeruginosa and Associated Microcystins Removal. Water Research. www.sciencedirect.com.

TSUJI, K.; WATANUKI, T.; KONDO, F.; WATANABE, M. F.; NAKAZAWA, H.; SUZUKI, M.; UCHIDA, H. \& HARADA, K. I. (1997). Stability of Microcistins from Cyanobacteria-IV. Effect of Chlorination on Decomposition. Toxicon, vol 35, $\mathrm{n}^{\circ} 7$, pp 1033 - 1041.

UTERMÖHL, H. (1958). Zur Vervollkomnung der quantitativen phytoplankton methodik.Mitt. Int. Verein. Theor. Angew. Limnol., v.9, p. 1-38.

VLASKI, A.; WAN BREEMEN, A. N.; ALAERTS, G. J. (1997) - The role of particle size and density in dissolved air flotation and sedimentation. Water Science and Technology. Vol. 36, no. 4, pp. 177-189.

WHITTON, B.A. \& POTTS, M.. The Ecology of Cyanobacteria. London, Kluwer Academic Publishers

WHO (1999). Toxic Cianobactéria in Water: A Guide to Their Public Health Consequences, 
Monitoring and Management. World Health Organization. Geneva.

ZAGATtO, P.A. (2000) - "Toxinas de Algas: Riscos à Saúde Pública". Revista Gerenciamento Ambiental. Ano 3, No 17, p $43-45$. 
ANEXO - MEMORIAIS DE CÁLCULO DO ESTUDO ECONÔMICO SIMPLIFICADO 


\section{Condição de Aplicação de CAP na Água de Estudo}

\section{1 - Dosagens}

Dosagem de cloreto férrico $=$

Dosagem de CAP =

\section{2 - Consumo de Cloreto Férrico}

$\mathrm{p} / \mathrm{Q}$ água bruta $=\quad 100 \mathrm{~L} / \mathrm{s}$

Consumo de coagulante $=$

$\mathrm{p} /$ solução comercial a

$\mathrm{p} /$ densidade da solução $=$

teor de produto ativo $=$

Consumo de solução comercial =

1003 L/dia

Consumo diário $=$

Densidade da solução comercial $=$

$65,0 \mathrm{mg} / \mathrm{L}$

$50,0 \mathrm{mg} / \mathrm{L}$
$6500 \mathrm{mg} / \mathrm{s}$ ou $\quad 23,4 \mathrm{~kg} / \mathrm{h}$

$\begin{array}{rl}40 & \% \\ 1400 & \mathrm{~kg} / \mathrm{m}^{3} \\ 560 \mathrm{~kg} / \mathrm{m}^{3}\end{array}$

Consumo diário $=\quad 1404,0 \mathrm{~kg} / \mathrm{dia}$

Custo da solução comercial $=\quad 0,87 \mathrm{R} \$ / \mathrm{kg}$

Custo diário $=\quad 1221 \mathrm{R} \$ / \mathrm{dia}$

$\mathrm{p} /$ volume diário de água tratada $=$

$8294,4 \mathrm{~m}^{3} / \mathrm{dia}$

Custo unitário $=$

$0,15 \mathrm{R} \$ / \mathrm{m}^{3}$

3 - Consumo de CAP

$\mathrm{p} / \mathrm{Q}$ água bruta $=\quad 100 \mathrm{~L} / \mathrm{s}$

Consumo de CAP $=5000 \mathrm{mg} / \mathrm{s}$ ou

$18 \mathrm{~kg} / \mathrm{h}$

Consumo diário $=\quad 432,0 \mathrm{~kg} / \mathrm{dia}$

Custo do CAP $=\quad 3,00 \mathrm{R} \$ / \mathrm{kg}$

Custo diário $=\quad 1296,00 \mathrm{R} \$ / \mathrm{dia}$

$\mathrm{p} /$ volume diário de água tratada $=$

$8294,4 \mathrm{~m}^{3} / \mathrm{dia}$

Custo unitário $=$

$0,16 \mathrm{R} \$ / \mathrm{m}^{3}$

\section{4 - Condicionamento e Disposição do Lodo Gerado}

\section{1 - Produção de Lodo}


Adota-se o Emprego da Expressão:

$T s=\left[\left(\right.\right.$ dos $\left.\mathrm{Fe}_{2} \mathrm{Cl}_{3} \cdot 0,40\right)+($ Turbidez da água bruta $\left.\times 1,5)\right]+$ dos CAP

Onde: dosagem de cloreto férrico em $\mathrm{mg} / \mathrm{L}$ turbidez da água bruta em uT

Ts é a produção de sólidos ( $\mathrm{gST} / \mathrm{m}^{3}$ de água tratada) dosagem de CAP em $\mathrm{g} / \mathrm{m}^{3}$

dos $\mathrm{Fe}_{2} \mathrm{Cl}_{3}=$

Turbidez da água de estudo $=$ dos $\mathrm{CAP}=$
$65,0 \mathrm{mg} / \mathrm{L}$

$37 \mathrm{mg} / \mathrm{L}\left(^{*}\right)$

$50,0 \mathrm{~g} / \mathrm{m}^{3}$

$\left(^{*}\right)$ - média dos valores de turbidez das águas de estudo 1, 2, 3 e 4

Ts $=\quad 131,5 \mathrm{gSST} / \mathrm{m}^{3}$ água tratada

$\mathrm{p} /$ volume diário de água bruta $=$

$8640 \mathrm{~m}^{3} / \mathrm{dia}$

Ts diária $=$

$1136160 \mathrm{gSST} / \mathrm{dia}$ ou

$1136 \mathrm{kgSST} / \mathrm{dia}$

\section{2 - Consumo de Polímero para o Condicionamento do Lodo}

Adota-se aplicação de polímero =

$8 \mathrm{~g} \mathrm{pol} / \mathrm{kgSST}$ secos

$\mathrm{p} /$ Ts diária $=$

$1136 \mathrm{kgSST} / \mathrm{dia}$

Consumo diário de polímero =

$9089 \mathrm{~g} / \mathrm{dia}$ ou

$9,09 \mathrm{~kg} / \mathrm{dia}$

Custo do polímero $=\quad 15,00 \mathrm{R} \$ / \mathrm{kg}$

Custo diário $=$ $136,34 \mathrm{R} \$ / \mathrm{dia}$

\section{3 - Transporte e Disposição Final do Lodo desaguado}

Adota-se teor do lodo desaguado $=$

$20 \%$ ou

$200 \mathrm{kgSST} / \mathrm{m}^{3}$

V lodo a ser transportado e disposto em aterro $=$

$5,68 \mathrm{~m}^{3} / \mathrm{dia}$

Densidade do lodo desaguado $=$

$1200 \mathrm{~kg} / \mathrm{m}^{3}$

Massa de lodo a ser transp. e disposta =

$6817 \mathrm{~kg} / \mathrm{dia}$ ou

6,82 ton/dia

Custo do transporte e disposição final =

$60 \mathrm{R} \$ /$ ton

Custo diário $=$

409,02 R $\$ /$ dia

Custo diário total $=$

$545,36 \mathrm{R} \$ / \mathrm{dia}$

$\mathrm{p} /$ volume diário de água tratada $=$

$8294,4 \mathrm{~m}^{3} / \mathrm{dia}$ 


\section{Condição de Pré-oxidação com Cloro}

\section{1 - Dosagens}

Dosagem de cloreto férrico $=$ Dosagem de cloro $=$

$65,0 \mathrm{mg} / \mathrm{L}$

$6,0 \mathrm{mg} / \mathrm{L}$

\section{2 - Consumo de Cloreto Férrico}

$\mathrm{p} / \mathrm{Q}$ água bruta $=$ $100 \mathrm{~L} / \mathrm{s}$

Consumo de coagulante $=$ $6500 \mathrm{mg} / \mathrm{s}$ ou $23,4 \mathrm{~kg} / \mathrm{h}$

$\mathrm{p} /$ solução comercial a $40 \%$ $\mathrm{p} /$ densidade da solução $=$ teor de produto ativo $=$

Consumo de solução comercial $=$

Consumo diário $=$ 1003 L/dia

Densidade da solução comercial = $1,4 \mathrm{~kg} / \mathrm{L}$

Consumo diário $=\quad 1404,0 \mathrm{~kg} / \mathrm{dia}$

Custo da solução comercial $=$

$0,87 \mathrm{R} \$ / \mathrm{kg}$

Custo diário $=$ $1221 \mathrm{R} \$ /$ dia

$\mathrm{p} /$ volume diário de água tratada $=$ $8294,4 \mathrm{~m}^{3} / \mathrm{dia}$

\section{Custo unitário $=$}

\section{$0,15 \mathrm{R} \$ / \mathrm{m}^{3}$}

\section{3 - Consumo de Cloro}

$\mathrm{p} / \mathrm{Q}$ água bruta = $100 \mathrm{~L} / \mathrm{s}$

Consumo de cloro $=$ $\mathrm{mg} / \mathrm{s}$

600 ou $2,16 \mathrm{~kg} / \mathrm{h}$

Emprego de hipoclorito de sódio

Teor de cloro na solução comercial = $10 \%$ Para densidade da solução $=$ $1200 \mathrm{~kg} / \mathrm{m}^{3}$

Teor de produto ativo $=$ $120 \mathrm{kgCl} / \mathrm{m}^{3}$

Consumo de solução comercial = $0,018 \mathrm{~m}^{3} / \mathrm{h}$ ou $18 \mathrm{~L} / \mathrm{h}$

Consumo diário $=$ 432,0 L/dia

Densidade da solução comercial $=$ $1,2 \mathrm{~kg} / \mathrm{L}$ 
Custo da solução comercial $=\quad 0,77 \mathrm{R} \$ / \mathrm{kg}$

Custo diário $=\quad 399,17 \mathrm{R} \$ /$ dia

$\mathrm{p} /$ volume diário de água tratada $=\quad 8294,4 \mathrm{~m}^{3} / \mathrm{dia}$

\section{Custo unitário $=\quad 0,05 \mathrm{R} \$ / \mathrm{m}^{3}$}

\section{4 - Condicionamento e Disposição do Lodo Gerado}

\section{1 - Produção de Lodo}

Adota-se o Emprego da Expressão:

Ts $=\left[\left(\right.\right.$ dos $\left.\mathrm{Fe}_{2} \mathrm{Cl}_{3} \cdot 0,40\right)+($ Turbidez da água bruta $\left.\times 1,5)\right]$

Onde: dosagem de cloreto férrico em $\mathrm{mg} / \mathrm{L}$ turbidez da água bruta em uT Ts é a produção de sólidos (g SST $/ \mathrm{m}^{3}$ de água tratada)

dos $\mathrm{Fe}_{2} \mathrm{Cl}_{3}=$

Turbidez da água de estudo $=$
$65,0 \mathrm{mg} / \mathrm{L}$

$37 \mathrm{mg} / \mathrm{L}\left(^{*}\right)$

${ }^{*}$ ) - média dos valores de turbidez das águas de estudo 1, 2, 3 e 4

Ts $=\quad 81,5 \mathrm{gSST} / \mathrm{m}^{3}$ água tratada

$\mathrm{p} /$ volume diário de água tratada $=$

$8640 \mathrm{~m}^{3} / \mathrm{dia}$

Ts diária $=$

704160 gSST/dia ou

$704 \mathrm{kgSST} / \mathrm{dia}$

\section{2 - Consumo de Polímero para o Condicionamento do Lodo}

Adota-se aplicação de polímero =

$8 \mathrm{~g} \mathrm{pol} / \mathrm{kgSST}$ secos

$\mathrm{p} /$ Ts diária $=$

$704 \mathrm{kgSST} / \mathrm{dia}$

Consumo diário de polímero $=$

$5633 \mathrm{~g} / \mathrm{dia}$ ou

$5,63 \mathrm{~kg} / \mathrm{dia}$

Custo do polímero $=$

$15,00 \mathrm{R} \$ / \mathrm{kg}$

Custo diário $=$

$84,50 \mathrm{R} \$ / \mathrm{dia}$

\section{3 - Transporte e Disposição Final do Lodo desaguado}

Adota-se teor do lodo desaguado $=$

V lodo a ser transportado e disposto em aterro $=$

Densidade do lodo desaguado $=$

Massa de lodo a ser transp. e disposta =

Custo do transporte e disposição final =
$20 \%$ ou

$200 \mathrm{kgSST} / \mathrm{m}^{3}$

\section{$3,52 \mathrm{~m}^{3} / \mathrm{dia}$}

$1200 \mathrm{~kg} / \mathrm{m}^{3}$

$4225 \mathrm{~kg} / \mathrm{dia}$ ou

4,22 ton/dia

$60 \mathrm{R} \$ /$ ton 
Custo diário $=\quad 253,50 \mathrm{R} \$ /$ dia

Custo diário total $=338,00 \mathrm{R} \$ / \mathrm{dia}$

$\mathrm{p} /$ volume diário de água tratada $=$

$8294,4 \mathrm{~m}^{3} / \mathrm{dia}$

\section{Custo unitário $=$}

$0,04 \mathrm{R} \$ / \mathrm{m}^{3}$ 


\title{
Condição de pré-oxidação com cloro + CAP na água coagulada
}

\author{
1 - Dosagens \\ Dosagem de cloreto férrico $=$ \\ Dosagem de Cloro $=$ \\ $65,0 \mathrm{mg} / \mathrm{L}$ \\ Dosagem de CAP = \\ $6,0 \mathrm{mg} / \mathrm{L}$ \\ $20,0 \mathrm{mg} / \mathrm{L}$
}

\section{2 - Consumo de Cloreto Férrico}

$\mathrm{p} / \mathrm{Q}$ água bruta $=\quad 100 \mathrm{~L} / \mathrm{s}$

Consumo de coagulante $=$

$\mathrm{p} /$ solução comercial a

$40 \%$

$\mathrm{p} /$ densidade da solução $=$

$1400 \mathrm{~kg} / \mathrm{m}^{3}$

teor de produto ativo $=$

$560 \mathrm{~kg} / \mathrm{m}^{3}$

Consumo de solução comercial $=$

$0,042 \mathrm{~m}^{3} / \mathrm{h}$ ou

$41,8 \mathrm{~L} / \mathrm{h}$

Consumo diário $=$

1003 L/dia

Densidade da solução comercial $=$

$1,4 \mathrm{~kg} / \mathrm{L}$

Consumo diário $=\quad 1404,0 \mathrm{~kg} / \mathrm{dia}$

Custo da solução comercial $=\quad 0,87 \mathrm{R} \$ / \mathrm{kg}$

Custo diário $=\quad 1221 \mathrm{R} \$ /$ dia

$\mathrm{p} /$ volume diário de água tratada $=$

$8294,4 \mathrm{~m}^{3} / \mathrm{dia}$

\section{Custo unitário $=\quad 0,15 \mathrm{R} \$ / \mathrm{m}^{3}$}

\section{3 - Consumo de Cloro}

$\mathrm{p} / \mathrm{Q}$ água bruta $=\quad 100 \mathrm{~L} / \mathrm{s}$

Consumo de cloro $=\quad 600 \mathrm{mg} / \mathrm{s}$ ou $\quad 2,16 \mathrm{~kg} / \mathrm{h}$

Emprego de hipoclorito de

sódio

Teor de cloro na solução comercial = $10 \%$

Para densidade da solução =

Teor de produto ativo $=$

$120 \mathrm{kgCl} / \mathrm{m}^{3}$

Consumo de solução comercial $=$

$0,018 \mathrm{~m}^{3} / \mathrm{h}$ ou

$18 \mathrm{~L} / \mathrm{h}$

Consumo diário $=\quad 432,0 \mathrm{~L} / \mathrm{dia}$

Densidade da solução comercial $=$ 
Consumo diário $=\quad 518,4 \mathrm{~kg} / \mathrm{dia}$

Custo da solução comercial $=\quad 0,77 \mathrm{R} \$ / \mathrm{kg}$

Custo diário $=\quad 399,17 \mathrm{R} \$ / \mathrm{dia}$

$\mathrm{p} /$ volume diário de água tratada $=\quad 8294,4 \mathrm{~m}^{3} / \mathrm{dia}$

Custo unitário $=\quad 0,05 \mathrm{R} \$ / \mathrm{m}^{3}$

\section{4 - Consumo de CAP}

$\mathrm{p} / \mathrm{Q}$ água bruta $=\quad 100 \mathrm{~L} / \mathrm{s}$

Consumo de CAP $=2000 \mathrm{mg} / \mathrm{s}$ ou $\quad 7,2 \mathrm{~kg} / \mathrm{h}$

Consumo diário $=\quad 172,8 \mathrm{~kg} / \mathrm{dia}$

Custo do CAP $=\quad 3,00 \mathrm{R} \$ / \mathrm{kg}$

Custo diário $=\quad 518,40 \mathrm{R} \$ /$ dia

$\mathrm{p} /$ volume diário de água tratada $=$

$8294,4 \mathrm{~m}^{3} / \mathrm{dia}$

Custo unitário $=\quad 0,06 \mathrm{R} \$ / \mathrm{m}^{3}$

\section{4 - Condicionamento e Disposição do Lodo Gerado}

\section{1 - Produção de Lodo}

Adota-se o Emprego da Expressão:

Ts $=\left[\left(\right.\right.$ dos $\left.\mathrm{Fe}_{2} \mathrm{Cl}_{3} \cdot 0,40\right)+($ Turbidez da água bruta $\left.\times 1,5)\right]+$ dos CAP

Onde: dosagem de cloreto férrico em $\mathrm{mg} / \mathrm{L}$ turbidez da água bruta em UT

Ts é a produção de sólidos ( $\mathrm{gSST} / \mathrm{m}^{3}$ de água tratada) dosagem de CAP em $\mathrm{g} / \mathrm{m}^{3}$

dos $\mathrm{Fe}_{2} \mathrm{Cl}_{3}=$

Turbidez da água de estudo $=$ dos $C A P=$
$65,0 \mathrm{mg} / \mathrm{L}$

$\left.37 \mathrm{mg} / \mathrm{L}^{*}\right)$

$20,0 \mathrm{~g} / \mathrm{m}^{3}$

${ }^{*}$ ) - média dos valores de turbidez das águas de estudo 1, 2, 3 e 4

Ts $=\quad 101,5 \mathrm{gSST} / \mathrm{m}^{3}$ água tratada

p/ volume diário de água bruta =

$8640 \mathrm{~m}^{3} / \mathrm{dia}$

Ts diária =

876960 gSST/dia ou

877 kgSST/dia 


\section{2 - Consumo de Polímero para o Condicionamento do Lodo}

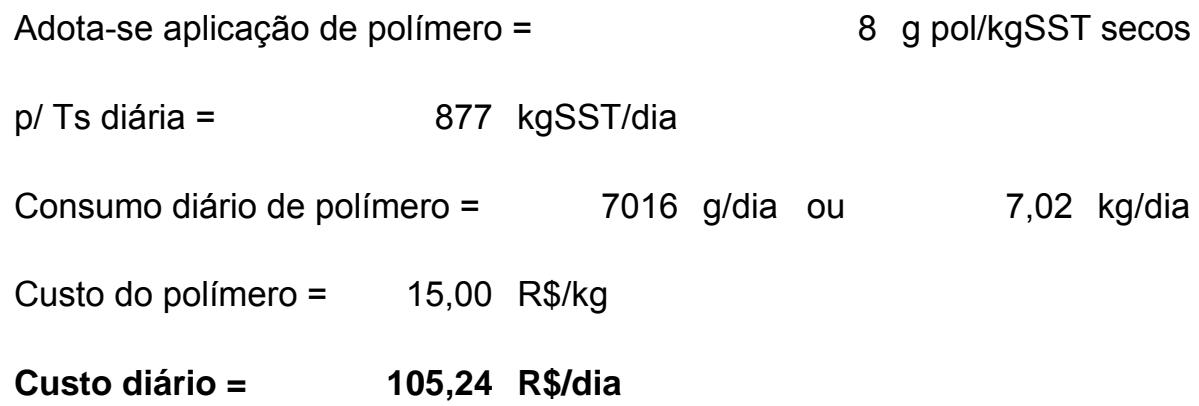

\section{3 - Transporte e Disposição Final do Lodo desaguado}

Adota-se teor do lodo desaguado $=$

V lodo a ser transportado e disposto em aterro $=$

Densidade do lodo desaguado $=$ $1200 \mathrm{~kg} / \mathrm{m}^{3}$

Massa de lodo a ser transp. e disposta =

Custo diário total $=\quad 420,94 \mathrm{R} \$ / \mathrm{dia}$

$\mathrm{p} /$ volume diário de água tratada $=$ $8294,4 \mathrm{~m}^{3} / \mathrm{dia}$

\section{Custo unitário $=\quad 0,05 \mathrm{R} \$ / \mathrm{m}^{3}$}




\section{Condição de Pós-oxidação com Cloro}

\section{1 - Dosagens}

Dosagem de cloreto férrico $=$

Dosagem de cloro =

$65,0 \mathrm{mg} / \mathrm{L}$

$3,0 \mathrm{mg} / \mathrm{L}$

\section{2 - Consumo de Cloreto Férrico}

$\mathrm{p} / \mathrm{Q}$ água bruta $=\quad 100 \mathrm{~L} / \mathrm{s}$

Consumo de coagulante $=$

$6500 \mathrm{mg} / \mathrm{s}$ ou

$23,4 \mathrm{~kg} / \mathrm{h}$

$\mathrm{p} /$ solução comercial a

$40 \%$

$\mathrm{p} /$ densidade da solução =

$1400 \mathrm{~kg} / \mathrm{m}^{3}$

teor de produto ativo $=$

$560 \mathrm{~kg} / \mathrm{m}^{3}$

Consumo de solução comercial =

$0,042 \mathrm{~m}^{3} / \mathrm{h} \mathrm{ou}$

$41,8 \mathrm{~L} / \mathrm{h}$

Consumo diário =

1003 L/dia

Densidade da solução comercial =

$1,4 \mathrm{~kg} / \mathrm{L}$

Consumo diário $=\quad 1404,0 \mathrm{~kg} / \mathrm{dia}$

Custo da solução comercial $=\quad 0,87 \mathrm{R} \$ / \mathrm{kg}$

Custo diário $=\quad 1221 \mathrm{R} \$ /$ dia

$\mathrm{p} /$ volume diário de água tratada $=$

$8294,4 \mathrm{~m}^{3} / \mathrm{dia}$

\section{Custo unitário $=\quad 0,15 \mathrm{R} \$ / \mathrm{m}^{3}$}

\section{3 - Consumo de Cloro}

$\mathrm{p} / \mathrm{Q}$ água bruta $=\quad 100 \mathrm{~L} / \mathrm{s}$

Consumo de cloro $=\quad 300 \mathrm{mg} / \mathrm{s}$ ou $\quad 1,08 \mathrm{~kg} / \mathrm{h}$

Emprego de hipoclorito de sódio

Teor de cloro na solução comercial =

$10 \%$

Para densidade da solução =

$1200 \mathrm{~kg} / \mathrm{m}^{3}$

Teor de produto ativo =

$120 \mathrm{kgCl} / \mathrm{m}^{3}$

Consumo de solução comercial =

$0,009 \mathrm{~m}^{3} / \mathrm{h}$ ou

$9 \mathrm{~L} / \mathrm{h}$

Consumo diário $=\quad 216,0 \mathrm{~L} / \mathrm{dia}$

Densidade da solução comercial =

$1,2 \mathrm{~kg} / \mathrm{L}$

Consumo diário =

$259,2 \mathrm{~kg} / \mathrm{dia}$ 
Custo da solução comercial $=\quad 0,77 \mathrm{R} \$ / \mathrm{kg}$

Custo diário $=\quad 199,58 \mathrm{R} \$ / \mathrm{dia}$

$\mathrm{p} /$ volume diário de água tratada $=\quad 8294,4 \mathrm{~m}^{3} / \mathrm{dia}$

\section{Custo unitário $=\quad 0,02 \mathrm{R} \$ / \mathrm{m}^{3}$}

\section{4 - Condicionamento e Disposição do Lodo Gerado}

\section{1 - Produção de Lodo}

Adota-se o Emprego da Expressão:

Ts $=\left[\left(\right.\right.$ dos $\left.\mathrm{Fe}_{2} \mathrm{Cl}_{3} \cdot 0,40\right)+($ Turbidez da água bruta $\left.\times 1,5)\right]$

Onde: dosagem de cloreto férrico em $\mathrm{mg} / \mathrm{L}$ turbidez da água bruta em uT Ts é a produção de sólidos ( $\mathrm{g} \mathrm{SST} / \mathrm{m}^{3}$ de água tratada)

dos $\mathrm{Fe}_{2} \mathrm{Cl}_{3}=$

Turbidez da água de estudo =
$65,0 \mathrm{mg} / \mathrm{L}$

$37 \mathrm{mg} / \mathrm{L}\left({ }^{*}\right)$

$\left(^{*}\right)$ - média dos valores de turbidez das águas de estudo 1, 2, 3 e 4

Ts $=\quad 81,5 \mathrm{gSST} / \mathrm{m}^{3}$ água tratada

p/ volume diário de água tratada $=$ $8640 \mathrm{~m}^{3} / \mathrm{dia}$

Ts diária $=$ 704160 gSST/dia ou

$704 \mathrm{kgSST} / \mathrm{dia}$

\section{2 - Consumo de Polímero para o Condicionamento do Lodo}

Adota-se aplicação de polímero =

$8 \mathrm{~g} \mathrm{pol} / \mathrm{kgSST}$ secos

$\mathrm{p} /$ Ts diária $=$

$704 \mathrm{kgSST} / \mathrm{dia}$

Consumo diário de polímero =

5633 g/dia ou

$5,63 \mathrm{~kg} / \mathrm{dia}$

Custo do polímero $=\quad 15,00 \mathrm{R} \$ / \mathrm{kg}$

Custo diário =

84,50 R\$/dia

\section{3 - Transporte e Disposição Final do Lodo desaguado}

Adota-se teor do lodo desaguado =

$\mathrm{V}$ lodo a ser transportado e disposto em aterro =

Densidade do lodo desaguado $=$

Massa de lodo a ser transp. e disposta =
$20 \%$ ou

$200 \mathrm{kgSST} / \mathrm{m}^{3}$

$$
3,52 \mathrm{~m}^{3} / \mathrm{dia}
$$

$1200 \mathrm{~kg} / \mathrm{m}^{3}$

$4225 \mathrm{~kg} / \mathrm{dia}$ ou

4,22 ton/dia 
Custo do transporte e disposição final =

Custo diário =

253,50 R\$/dia

Custo diário total $=\quad 338,00 \mathrm{R} \$ /$ dia

p/ volume diário de água tratada $=$

Custo unitário $=$ $0,04 \mathrm{R} \$ / \mathrm{m}^{3}$
$60 \mathrm{R} \$ /$ ton

$8294,4 \mathrm{~m}^{3} / \mathrm{dia}$ 


\section{Condição de Inter-oxidação com $\mathrm{KMnO}_{4}+$ Cloro}

\section{1 - Dosagens}

Dosagem de cloreto férrico $=$ Dosagem de $\mathrm{MnO} 4=$

Dosagem de cloro $=$

2 - Consumo de Cloreto Férrico

$\mathrm{p} / \mathrm{Q}$ água bruta $=$ $100 \mathrm{~L} / \mathrm{s}$

Consumo de coagulante $=$

$\mathrm{p} /$ solução comercial a $\mathrm{p} /$ densidade da solução $=$ teor de produto ativo $=$

Consumo de solução comercial $=$

Consumo diário $=$ 1003 L/dia

Densidade da solução comercial $=$

Consumo diário $=$ $1404,0 \mathrm{~kg} / \mathrm{dia}$

Custo da solução comercial $=$ $0,87 \mathrm{R} \$ / \mathrm{kg}$

Custo diário $=$ $1221 \mathrm{R} \$ /$ dia

$\mathrm{p} /$ volume diário de água tratada $=$

\author{
$65,0 \mathrm{mg} / \mathrm{L}$ \\ $0,3 \mathrm{mg} / \mathrm{L}$ \\ $3,0 \mathrm{mg} / \mathrm{L}$
}

$6500 \mathrm{mg} / \mathrm{s}$ ou $\quad 23,4 \mathrm{~kg} / \mathrm{h}$

$40 \%$

$1400 \mathrm{~kg} / \mathrm{m}^{3}$

$560 \mathrm{~kg} / \mathrm{m}^{3}$

$$
0,042 \mathrm{~m}^{3} / \mathrm{h} \text { ou } \quad 41,8 \mathrm{~L} / \mathrm{h}
$$

$1,4 \mathrm{~kg} / \mathrm{L}$

\section{Custo unitário $=\quad 0,15 \mathrm{R} \$ / \mathrm{m}^{3}$}

\section{3 - Consumo de $\mathrm{KMnO}_{4}$}

p/ Q água bruta $=\quad 100 \mathrm{~L} / \mathrm{s}$

Consumo de $\mathrm{MnO}_{4}{ }^{-}=\quad 30 \mathrm{mg} / \mathrm{s}$ ou $\quad 0,108 \mathrm{~kg} / \mathrm{h}$

Teor de $\mathrm{MnO}_{4}{ }^{-}$no $\mathrm{KMnO}_{4}$ :

Peso molecular do $\mathrm{KMnO}_{4}=\quad 158$

Peso molecular do $\mathrm{MnO}_{4}{ }^{-}=119$

Portanto, teor de $\mathrm{MnO}_{4}{ }^{-}=\quad 75 \%$

Pureza do produto comercial $=\quad 98 \%$

Portanto, Teor de $\mathrm{MnO}_{4}$ no produto comercial = 
Consumo de $\mathrm{KMnO}_{4}$ comercial =

Consumo diário de $\mathrm{KMnO}_{4}$ comercial =

Custo do $\mathrm{KMnO}_{4}$ comercial $=$

Custo diário $=$

$52,90 \mathrm{R} \$ / \mathrm{dia}$

$\mathrm{p} /$ volume diário de água tratada $=$
$0,147 \mathrm{~kg} / \mathrm{h}$

$3,5 \mathrm{~kg} / \mathrm{dia}$

$15 \mathrm{R} \$ / \mathrm{kg}$

$8294,4 \mathrm{~m}^{3} / \mathrm{dia}$

\section{3 - Consumo de Cloro \\ $\mathrm{p} / \mathrm{Q}$ água bruta $=\quad 100 \mathrm{~L} / \mathrm{s}$ \\ Consumo de cloro $=\quad 300 \mathrm{mg} / \mathrm{s}$ ou $\quad 1,08 \mathrm{~kg} / \mathrm{h}$}

Emprego de hipoclorito de sódio

Teor de cloro na solução comercial = $10 \%$ Para densidade da solução = $1200 \mathrm{~kg} / \mathrm{m}^{3}$

Teor de produto ativo $=$ $120 \mathrm{kgCl} / \mathrm{m}^{3}$

Consumo de solução comercial = $0,009 \mathrm{~m}^{3} / \mathrm{h}$ ou $9 \mathrm{~L} / \mathrm{h}$

Consumo diário $=\quad 216,0 \mathrm{~L} / \mathrm{dia}$

Densidade da solução comercial = $1,2 \mathrm{~kg} / \mathrm{L}$

Consumo diário $=\quad 259,2 \mathrm{~kg} / \mathrm{dia}$

Custo da solução comercial $=\quad 0,77 \mathrm{R} \$ / \mathrm{kg}$

Custo diário $=\quad 199,58 \mathrm{R} \$ / \mathrm{dia}$

$\mathrm{p} /$ volume diário de água tratada $=$ $8294,4 \mathrm{~m}^{3} / \mathrm{dia}$

\section{Custo unitário $=\quad 0,02 \mathrm{R} \$ / \mathrm{m}^{3}$}

\section{5 - Condicionamento e Disposição do Lodo Gerado}

\section{1 - Produção de Lodo}

Adota-se o Emprego da Expressão:

Ts $=\left[\left(\right.\right.$ dos $\left.\mathrm{Fe}_{2} \mathrm{Cl}_{3} \cdot 0,40\right)+($ Turbidez da água bruta $\left.\times 1,5)\right]$

Onde: dosagem de cloreto férrico em $\mathrm{mg} / \mathrm{L}$ turbidez da água bruta em uT

Ts é a produção de sólidos ( $\mathrm{gST} / \mathrm{m}^{3}$ de água tratada) 
dos $\mathrm{Fe}_{2} \mathrm{Cl}_{3}=$

Turbidez da água de estudo $=$
$65,0 \mathrm{mg} / \mathrm{L}$

$37 \mathrm{mg} / \mathrm{L}\left(^{*}\right)$

$\left({ }^{*}\right)$ - média dos valores de turbidez das águas de estudo 1, 2, 3 e 4

Ts $=$ $81,5 \mathrm{gSST} / \mathrm{m}^{3}$ água tratada

p/ volume diário de água tratada $=$ $8640 \mathrm{~m}^{3} / \mathrm{dia}$

Ts diária $=$

704160 gSST/dia ou

$704 \mathrm{kgSST} / \mathrm{dia}$

\section{2 - Consumo de Polímero para o Condicionamento do Lodo}

Adota-se aplicação de polímero =

$8 \mathrm{~g} \mathrm{pol} / \mathrm{kgSST}$ secos

$\mathrm{p} /$ Ts diária $=$

$704 \mathrm{kgSST} / \mathrm{dia}$

Consumo diário de polímero =

5633 g/dia ou

$5,63 \mathrm{~kg} / \mathrm{dia}$

Custo do polímero $=\quad 15,00 \mathrm{R} \$ / \mathrm{kg}$

Custo diário =

$$
84,50 \mathrm{R} \$ / d i a
$$

\section{3 - Transporte e Disposição Final do Lodo desaguado}

Adota-se teor do lodo desaguado =

$20 \%$ ou

$200 \mathrm{kgSST} / \mathrm{m}^{3}$

V lodo a ser transportado e disposto em aterro =

$3,52 \mathrm{~m}^{3} / \mathrm{dia}$

Densidade do lodo desaguado $=$

$1200 \mathrm{~kg} / \mathrm{m}^{3}$

Massa de lodo a ser transp. e disposta =

$4225 \mathrm{~kg} / \mathrm{dia}$ ou

4,22 ton/dia

Custo do transporte e disposição final =

$60 \mathrm{R} \$ /$ ton

Custo diário =

253,50 R\$/dia

Custo diário total $=\quad 338,00 \mathrm{R} \$ /$ dia

$\mathrm{p} /$ volume diário de água tratada $=$

$8294,4 \quad \mathrm{~m}^{3} / \mathrm{dia}$ 


\section{Condição de Pré-oxidação com $\mathrm{KMnO}_{4} \mathrm{e}$ Pós-oxidação com Cloro}

\section{1 - Dosagens}

Dosagem de cloreto férrico $=$ Dosagem de $\mathrm{MnO} 4=$

$140,0 \mathrm{mg} / \mathrm{L}$

$3,0 \mathrm{mg} / \mathrm{L}$

$3,0 \mathrm{mg} / \mathrm{L}$

\section{2 - Consumo de Cloreto Férrico}

$\mathrm{p} / \mathrm{Q}$ água bruta $=\quad 100 \mathrm{~L} / \mathrm{s}$

Consumo de coagulante $=$ $14000 \mathrm{mg} / \mathrm{s}$ ou $\quad 50,4 \mathrm{~kg} / \mathrm{h}$

$\mathrm{p} /$ solução comercial a

$40 \%$

$\mathrm{p} /$ densidade da solução $=$

teor de produto ativo $=$

$1400 \mathrm{~kg} / \mathrm{m}^{3}$

$560 \mathrm{~kg} / \mathrm{m}^{3}$

Consumo de solução comercial $=$

$0,090 \mathrm{~m}^{3} / \mathrm{h}$ ou

$90,0 \mathrm{~L} / \mathrm{h}$

Consumo diário $=\quad 2160 \mathrm{~L} / \mathrm{dia}$

Densidade da solução comercial =

$1,4 \mathrm{~kg} / \mathrm{L}$

Consumo diário $=\quad 3024,0 \mathrm{~kg} / \mathrm{dia}$

Custo da solução comercial $=\quad 0,87 \mathrm{R} \$ / \mathrm{kg}$

Custo diário $=\quad 2631 \mathrm{R} \$ /$ dia

$\mathrm{p} /$ volume diário de água tratada $=$

$8294,4 \mathrm{~m}^{3} / \mathrm{dia}$

\section{Custo unitário $=\quad 0,32 \mathrm{R} \$ / \mathrm{m}^{3}$}

\section{3 - Consumo de $\mathrm{KMnO}_{4}$}

$\mathrm{p} / \mathrm{Q}$ água bruta $=\quad 100 \mathrm{~L} / \mathrm{s}$

Consumo de $\mathrm{MnO}_{4}^{-}=300 \mathrm{mg} / \mathrm{s}$ ou $\quad 1,08 \mathrm{~kg} / \mathrm{h}$

Teor de $\mathrm{MnO}_{4}{ }^{-}$no $\mathrm{KMnO}_{4}$ :

Peso molecular do $\mathrm{KMnO}_{4}=\quad 158$

Peso molecular do $\mathrm{MnO}_{4}^{-}=$

Portanto, teor de $\mathrm{MnO}_{4}{ }^{-}=\quad 75 \%$

Pureza do produto comercial $=\quad 98 \%$

Portanto, Teor de $\mathrm{MnO}_{4}{ }^{-}$no produto comercial = 
Consumo de $\mathrm{KMnO}_{4}$ comercial =

Consumo diário de $\mathrm{KMnO}_{4}$ comercial =

Custo do $\mathrm{KMnO}_{4}$ comercial $=$

Custo diário $=$

$528,98 \mathrm{R} \$ /$ dia

$\mathrm{p} /$ volume diário de água tratada $=$

Custo unitário $=$

\section{$0,06 \mathrm{R} \$ / \mathrm{m}^{3}$}

\section{4 - Consumo de Cloro}

$\mathrm{p} / \mathrm{Q}$ água bruta $=$ 100 L/s

Consumo de cloro $=$ $300 \mathrm{mg} / \mathrm{s}$ ou

$1,08 \mathrm{~kg} / \mathrm{h}$

Emprego de hipoclorito de sódio

Teor de cloro na solução comercial = Para densidade da solução $=$

Teor de produto ativo $=$

$10 \%$

$1200 \mathrm{~kg} / \mathrm{m}^{3}$

$120 \mathrm{kgCl} / \mathrm{m}^{3}$

Consumo de solução comercial =

$0,009 \mathrm{~m}^{3} / \mathrm{h}$ ou

$9 \mathrm{~L} / \mathrm{h}$

Consumo diário $=\quad 216,0 \mathrm{~L} / \mathrm{dia}$

Densidade da solução comercial =

Consumo diário $=$

$259,2 \mathrm{~kg} / \mathrm{dia}$

Custo da solução comercial $=$

$0,77 \mathrm{R} \$ / \mathrm{kg}$

Custo diário $=$

$199,58 \mathrm{R} \$ /$ dia

$\mathrm{p} /$ volume diário de água tratada $=$

$8294,4 \mathrm{~m}^{3} / \mathrm{dia}$

\section{Custo unitário $=\quad 0,02 \mathrm{R} \$ / \mathrm{m}^{3}$}

\section{5 - Condicionamento e Disposição do Lodo Gerado}

\section{1 - Produção de Lodo}

Adota-se o Emprego da Expressão:

Ts $=\left[\left(\right.\right.$ dos $\left.\mathrm{Fe}_{2} \mathrm{Cl}_{3} \cdot 0,40\right)+($ Turbidez da água bruta $\left.\times 1,5)\right]$

Onde: dosagem de cloreto férrico em $\mathrm{mg} / \mathrm{L}$ turbidez da água bruta em uT Ts é a produção de sólidos ( $\mathrm{g} \mathrm{SST} / \mathrm{m}^{3}$ de água tratada) 
$\operatorname{dos} \mathrm{Fe}_{2} \mathrm{Cl}_{3}=$

Turbidez da água de estudo $=$
$140,0 \mathrm{mg} / \mathrm{L}$

$\left.37 \mathrm{mg} / \mathrm{L}^{*}\right)$

$\left(^{*}\right)$ - média dos valores de turbidez das águas de estudo 1, 2, 3 e 4

Ts $=$

$111,5 \mathrm{gSST} / \mathrm{m}^{3}$ água tratada

$\mathrm{p} /$ volume diário de água tratada $=$

$8640 \mathrm{~m}^{3} / \mathrm{dia}$

Ts diária $=$

963360 gSST/dia ou

$963 \mathrm{kgSST} / \mathrm{dia}$

\section{2 - Consumo de Polímero para o Condicionamento do Lodo}

Adota-se aplicação de polímero =

$8 \mathrm{~g} \mathrm{pol} / \mathrm{kgSST}$ secos

$\mathrm{p} /$ Ts diária $=$

$963 \mathrm{kgSST} / \mathrm{dia}$

Consumo diário de polímero =

$7707 \mathrm{~g} / \mathrm{dia}$ ou

$7,71 \mathrm{~kg} / \mathrm{dia}$

Custo do polímero $=\quad 15,00 \mathrm{R} \$ / \mathrm{kg}$

\section{Custo diário $=\quad 115,60 \mathrm{R} \$ / \mathrm{dia}$}

\section{3 - Transporte e Disposição Final do Lodo desaguado}

Adota-se teor do lodo desaguado $=$

$20 \%$ ou

$200 \mathrm{kgSST} / \mathrm{m}^{3}$

V lodo a ser transportado e disposto em aterro $=$

$4,82 \mathrm{~m}^{3} / \mathrm{dia}$

Densidade do lodo desaguado $=$

$1200 \mathrm{~kg} / \mathrm{m}^{3}$

Massa de lodo a ser transp. e disposta $=$

$5780 \mathrm{~kg} / \mathrm{dia}$ ou

5,78 ton/dia

Custo do transporte e disposição final =

$60 \mathrm{R} \$ /$ ton

\section{Custo diário $=\quad 346,81 \mathrm{R} \$ / \mathrm{dia}$}

Custo diário total $=462,41 \mathrm{R} \$ / \mathrm{dia}$

$\mathrm{p} /$ volume diário de água tratada $=$

$8294,4 \mathrm{~m}^{3} / \mathrm{dia}$

Custo unitário $=\quad 0,06 \mathrm{R} \$ / \mathrm{m}^{3}$




\title{
Condição de Pré-oxidação com $\mathrm{KMnO}_{4}$ e Cloro e Pós-oxidação com Cloro
}

\author{
1 - Dosagens \\ Dosagem de cloreto férrico $=\quad 140,0 \mathrm{mg} / \mathrm{L}$ \\ Dosagem de $\mathrm{MnO} 4=\quad 4,0 \mathrm{mg} / \mathrm{L}$ \\ Dosagem de cloro $($ pré $)=\quad 2,0 \mathrm{mg} / \mathrm{L}$ \\ Dosagem de cloro (pós) $=\quad 3,0 \mathrm{mg} / \mathrm{L}$
}

2 - Consumo de Cloreto Férrico

$\mathrm{p} / \mathrm{Q}$ água bruta $=\quad 100 \mathrm{~L} / \mathrm{s}$

Consumo de coagulante $=$

$14000 \mathrm{mg} / \mathrm{s}$ ou $\quad 50,4 \mathrm{~kg} / \mathrm{h}$

$\mathrm{p} /$ solução comercial a

$40 \%$

$\mathrm{p} /$ densidade da solução $=\quad 1400 \mathrm{~kg} / \mathrm{m}^{3}$

teor de produto ativo $=\quad 560 \mathrm{~kg} / \mathrm{m}^{3}$

Consumo de solução comercial $=$

$0,090 \mathrm{~m}^{3} / \mathrm{h}$ ou $\quad 90,0 \mathrm{~L} / \mathrm{h}$

Consumo diário $=\quad 2160 \mathrm{~L} / \mathrm{dia}$

Densidade da solução comercial $=$

$1,4 \mathrm{~kg} / \mathrm{L}$

Consumo diário $=\quad 3024,0 \mathrm{~kg} / \mathrm{dia}$

Custo da solução comercial $=\quad 0,87 \mathrm{R} \$ / \mathrm{kg}$

Custo diário $=\quad 2631 \mathrm{R} \$ /$ dia

$\mathrm{p} /$ volume diário de água tratada $=\quad 8294,4 \quad \mathrm{~m}^{3} / \mathrm{dia}$

\section{Custo unitário $=\quad 0,32 \mathrm{R} \$ / \mathrm{m}^{3}$}

3 - Consumo de $\mathrm{KMnO}_{4}$

$\mathrm{p} / \mathrm{Q}$ água bruta $=\quad 100 \mathrm{~L} / \mathrm{s}$

Consumo de $\mathrm{MnO}_{4}{ }^{-}=\quad 400 \mathrm{mg} / \mathrm{s}$ ou $\quad 1,44 \mathrm{~kg} / \mathrm{h}$

Teor de $\mathrm{MnO}_{4}{ }^{-}$no $\mathrm{KMnO}_{4}$ :

Peso molecular do $\mathrm{KMnO}_{4}=\quad 158$

Peso molecular do $\mathrm{MnO}_{4}{ }^{-}=$

Portanto, teor de $\mathrm{MnO}_{4}{ }^{-}=\quad 75 \%$

Pureza do produto comercial $=\quad 98 \%$ 
Portanto, Teor de $\mathrm{MnO}_{4}{ }^{-}$no produto comercial $=$

Consumo de $\mathrm{KMnO}_{4}$ comercial =

$1,959 \mathrm{~kg} / \mathrm{h}$

Consumo diário de $\mathrm{KMnO}_{4}$ comercial =

$47,0 \mathrm{~kg} / \mathrm{dia}$

Custo do $\mathrm{KMnO}_{4}$ comercial $=$

$15 \mathrm{R} \$ / \mathrm{kg}$

Custo diário $=$

$705,31 \mathrm{R} \$ / \mathrm{dia}$

$\mathrm{p} /$ volume diário de água tratada $=$

$8294,4 \mathrm{~m}^{3} / \mathrm{dia}$

\section{Custo unitário $=\quad 0,09 \mathrm{R} \$ / \mathrm{m}^{3}$}

\section{4 - Consumo de Cloro}

$\mathrm{p} / \mathrm{Q}$ água bruta $=\quad 100 \mathrm{~L} / \mathrm{s}$

Consumo de cloro $=\quad 500 \mathrm{mg} / \mathrm{s}$ ou $\quad 1,8 \mathrm{~kg} / \mathrm{h}$

Emprego de hipoclorito de sódio

Teor de cloro na solução comercial = $10 \%$ Para densidade da solução $=$ $1200 \mathrm{~kg} / \mathrm{m}^{3}$

Teor de produto ativo $=$

$120 \mathrm{kgCl} / \mathrm{m}^{3}$

Consumo de solução comercial $=$

Consumo diário $=\quad 360,0 \mathrm{~L} / \mathrm{dia}$

Densidade da solução comercial = $1,2 \mathrm{~kg} / \mathrm{L}$

Consumo diário $=\quad 432,0 \mathrm{~kg} / \mathrm{dia}$

Custo da solução comercial $=\quad 0,77 \mathrm{R} \$ / \mathrm{kg}$

Custo diário $=\quad 332,64 \mathrm{R} \$ / \mathrm{dia}$

$\mathrm{p} /$ volume diário de água tratada $=$

$8294,4 \mathrm{~m}^{3} / \mathrm{dia}$

\section{Custo unitário $=\quad 0,04 \mathrm{R} \$ / \mathrm{m}^{3}$}

\section{5 - Condicionamento e Disposição do Lodo Gerado}

\section{1 - Produção de Lodo}

Adota-se o Emprego da Expressão:

$T s=\left[\left(\right.\right.$ dos $\left.\mathrm{Fe}_{2} \mathrm{Cl}_{3} \cdot 0,40\right)+($ Turbidez da água bruta $\left.\times 1,5)\right]$

Onde: dosagem de cloreto férrico em $\mathrm{mg} / \mathrm{L}$ turbidez da água bruta em uT 
Ts é a produção de sólidos ( $\mathrm{g} \mathrm{SST} / \mathrm{m}^{3}$ de água tratada)

dos $\mathrm{Fe}_{2} \mathrm{Cl}_{3}=$

Turbidez da água de estudo $=$
$140,0 \mathrm{mg} / \mathrm{L}$

$37 \mathrm{mg} / \mathrm{L}\left(^{*}\right)$

$\left(^{*}\right)$ - média dos valores de turbidez das águas de estudo 1, 2, 3 e 4

Ts $=\quad 111,5 \mathrm{gSST} / \mathrm{m}^{3}$ água tratada

$\mathrm{p} /$ volume diário de água tratada $=$

$8640 \mathrm{~m}^{3} / \mathrm{dia}$

Ts diária $=$

963360 gSST/dia ou

$963 \mathrm{kgSST} / \mathrm{dia}$

\section{2 - Consumo de Polímero para o Condicionamento do Lodo}

Adota-se aplicação de polímero =

$8 \mathrm{~g} \mathrm{pol} / \mathrm{kgSST}$ secos

$\mathrm{p} /$ Ts diária $=$

$963 \mathrm{kgSST} / \mathrm{dia}$

Consumo diário de polímero $=$

$7707 \mathrm{~g} / \mathrm{dia}$ ou

$7,71 \mathrm{~kg} / \mathrm{dia}$

Custo do polímero $=$

$15,00 \mathrm{R} \$ / \mathrm{kg}$

Custo diário $=$

$115,60 \mathrm{R} \$$ /dia

\section{3 - Transporte e Disposição Final do Lodo desaguado}

Adota-se teor do lodo desaguado $=$

$20 \%$ ou

$200 \mathrm{kgSST} / \mathrm{m}^{3}$

V lodo a ser transportado e disposto em aterro $=$

$4,82 \mathrm{~m}^{3} / \mathrm{dia}$

Densidade do lodo desaguado $=$

$1200 \mathrm{~kg} / \mathrm{m}^{3}$

Massa de lodo a ser transp. e disposta $=$

$5780 \mathrm{~kg} / \mathrm{dia}$ ou $\quad 5,78 \mathrm{ton} / \mathrm{dia}$

Custo do transporte e disposição final =

$60 \mathrm{R} \$ /$ ton

Custo diário $=$

$346,81 \mathrm{R} \$ / \mathrm{dia}$

Custo diário total $=\quad 462,41 \mathrm{R} \$ /$ dia

$\mathrm{p} /$ volume diário de água tratada $=$

$8294,4 \mathrm{~m}^{3} / \mathrm{dia}$ 